United States

Environmental Protection Agency
Office of Policy,

Planning and Evaluation

Washington, DC 20460

\title{
BEPA
}

Greenhouse Effect Sea Level Rise and

\section{Coastal Wetlands}
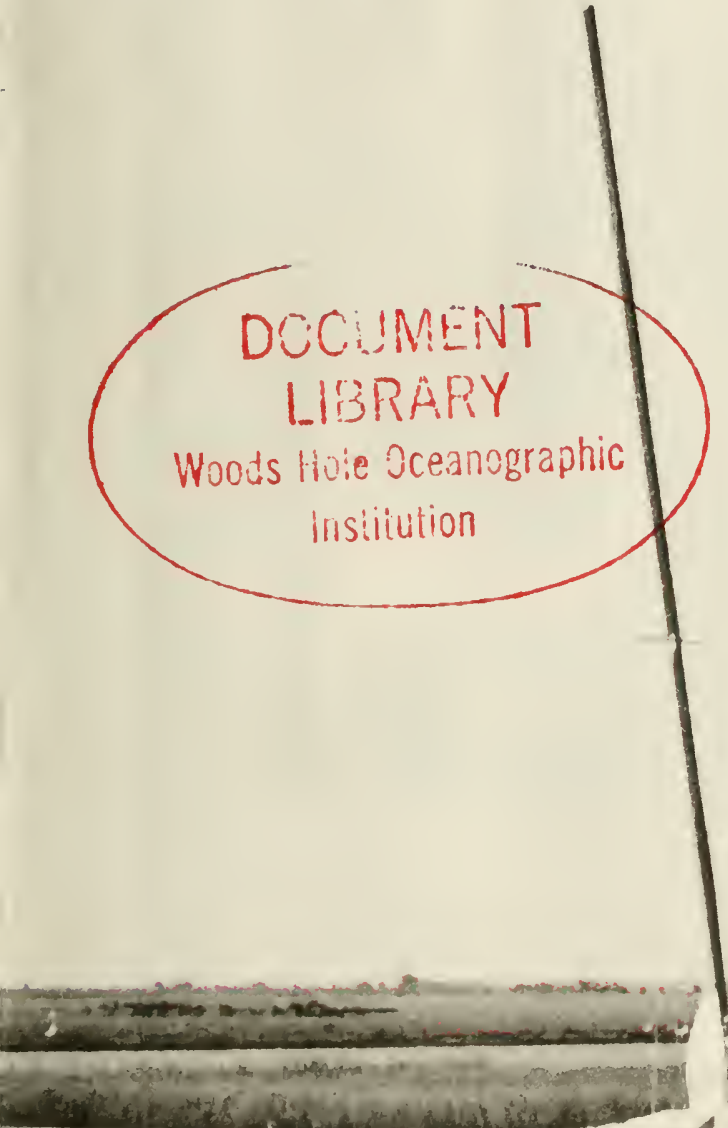

QH

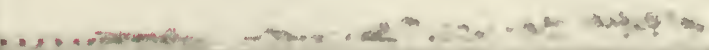

104

.674 1988

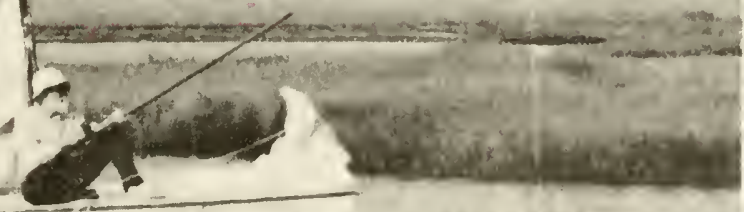



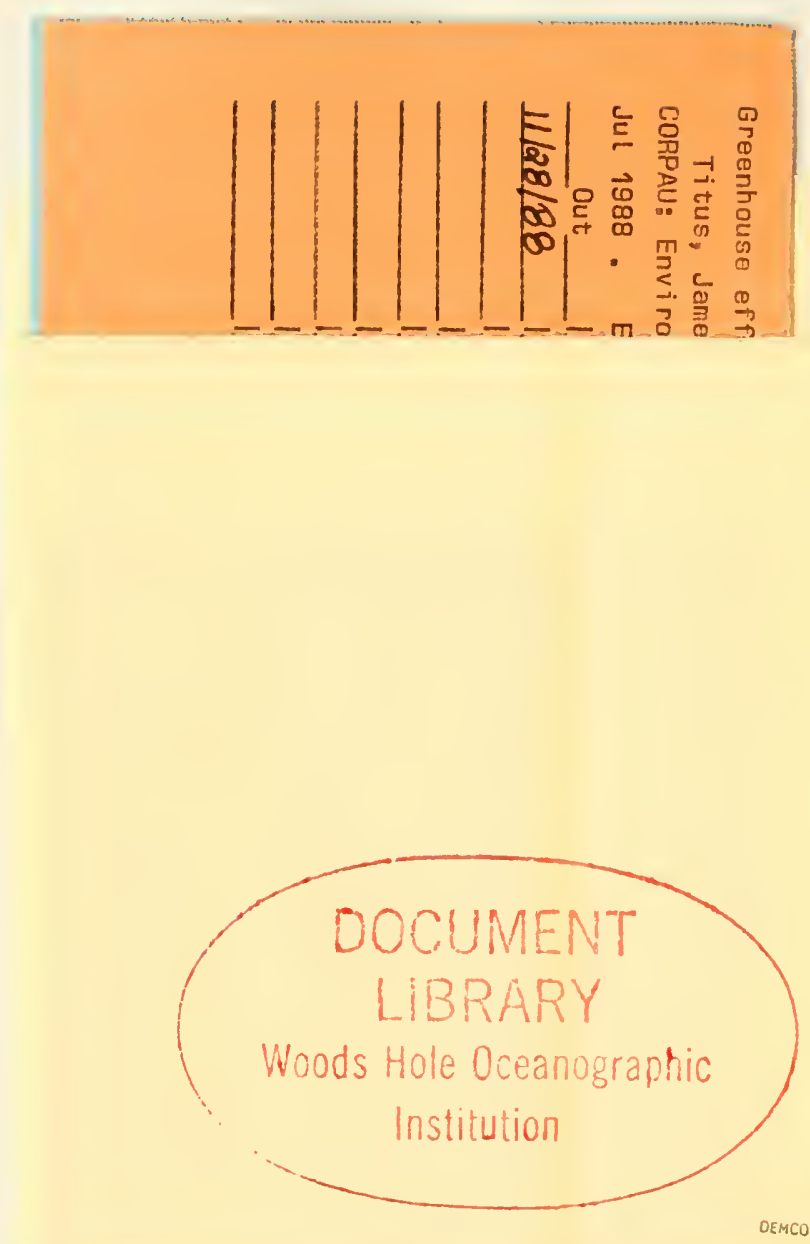

Library of Congress Cataloging-in-Publication Data

Greenhouse effect, sea level rise, and coastal wetlands.

Includes bibliographies.

1. Wetlands--United States. 2. Wetland conservation-United States. 3. Greenhouse effect, Atmospheric--United States. 4. Sea level--South Carolina--Charleston Region. 5. Sea level--New Jersey--Long Beach Island. 6. Sea level--United States. I. Titus, James G. 


\title{
GREENHOUSE EFFECT, SEA LEVEL RISE AND COASTAL WETLANDS
}

\author{
Edited by \\ James G. Titus \\ U.S. Environmental Protection Agency \\ Other Contributors: \\ Timothy W. Kana \\ Bart J. Baca \\ William C. Eiser \\ Mark L. Williams \\ Coastal Scientists \\ Thomas V. Armentano \\ Richard A. Park \\ C. Leslie Cloonan \\ Holcomb Research Institute \\ Butler University \\ Office of Wetland Protection \\ U.S. Environmental Protection Agency
}

This document has been reviewed in accordance with the U.S. Environmental Protection Agency's peer and administrative review policies and approved for publication. Mention of trade names or commercial products does not constitute endorsement or recommendation for use. Please send comments to James G. Titus, Office of Policy Analysis, U.S. Environmental Protection Agency, Washington, D.C. 20460. 


\section{SUMMARY}

Increasing atmospheric concentrations of carbon dioxide and other gases released by human activities are generally expected to warm the earth a few degrees $(\mathrm{C})$ in the next century by a mechanism commonly known as the "greenhouse effect." Such a warming could raise sea level by expanding ocean water, melting mountain glaciers, and eventually causing polar ice sheets to slide into the oceans. Unfortunately, it is not yet possible to accurately predict future sea level. Estimates for the year 2025 range from five to fifteen inches above current sea level, while estimates of the rise by 2100 range from two to seven feet. Although the timing and magnitude of future sea level rise is uncertain, there is an emerging scientific consensus that a significant rise is likely.

To further society's understanding of how to rationally respond to the possibility of a substantial rise in sea level, EPA has undertaken assessments of the impacts of sea level rise on economic development, beach erosion control strategies, salinity of estuaries and aquifers, and coastal drainage and sewage systems. Those studies have generally found that even a one-foot rise in sea level has important implications for the planning and design of coastal facilities.

This report examines the potential impacts of sea level rise on coastal wetlands in the United States. Coastal marshes and swamps are generally within a few feet of sea level, and hence could be lost if sea level rises significantly. Although new wetlands could form where new areas are flooded, this cannot happen where the land adjacent to today's wetlands is developed and protected from the rising sea. Once built, neighborhoods can be expected to last a century or longer. Therefore, today's coastal development could limit the ability of coastal wetlands to survive sea level rise in the next century.

Chapter 1 provides an overview of the greenhouse effect, projections of future sea level rise, the basis for expecting significant impacts on coastal wetlands, and possible responses. Chapters 2 and 3 present case studies of the potential impacts on wetlands around Charleston, South Carolina, and Long Beach Island, New Jersey, based on field surveys. Chapter 4 presents a first attempt to estimate the nationwide impact, based on topographic maps. Finally, Chapter 5 describes measures that wetland protection officials can take today. This report neither examines the impact of sea level rise on specific federal programs nor recommends specific policy changes. 


\section{CONCLUSIONS}

1. Along undeveloped coasts, a rise in sea level drowns the seaward wetlands and allows new uetlands to be created inland as formerly dry land is flooded. However, for the rise in sea level expected in the next century, the area just above sea level available for wetland creation is generally far smaller than the area of wetlands that would be lost. Along developed coasts, there may not be any land available for wetland creation.

2. Sea level rise could become a major cause of wetland loss throughout the coastal zone of the United States. Assuming that current rates of vertical wetland growth continue and that economic development does not prevent the formation of new wetlands, a five-foot rise would result in 80 percent losses of wetlands in both the South Carolina and New Jersey case studies. In the preliminary nationwide analysis, a five- to seven-foot rise would result in a 30 to 80 percent loss of coastal wetlands.

3. The coastal uetlands of Louisiana appear to be the most vulnerable to a rise in sea level. The coastal wetlands of the Mississippi River delta are already converting to open water at a rate of 50 square miles per year because of the interaction between human activities, such as construction of levees and navigation channels, and current relative sea level trends caused by land subsidence. Future sea level rise could substantially accelerate the rate of wetland loss and alter the relative advantages of various options to solve the problem.

4. The impact of sea level rise on coastal wetlands will depend in large measure on whether developed areas immediately inland of the marsh are protected from rising sea level by levees and bulkheads. In the Charleston case study, protecting developed areas would increase the 80 percent wetland loss to 90 percent for a five-foot rise. In the nationwide analysis, structural protection would increase the 30-80 percent loss to 50-90 percent.

5. Factors not considered in this report could increase or decrease the vulnerability of wetlands to a rise in sea level. This report does not attempt to estimate the change in rates of vertical marsh growth that might accompany a global warming and rise in sea level.

6. Federal and state agencies responsible for wetland protection should now begin to determine how to mitigate the loss of wetlands from sea level rise. Outside of Louisiana, the most substantial losses are at least 50 years away. However, today's coastal development may largely determine the success with which wetlands adjust to rising sea level in the future.

7. The prospect of accelerated sea level rise does not decrease the need to implement existing wetland protection policies. Numerous federal, state, and local programs are being implemented to curtail the destruction of the nation's dwindling coastal wetlands. Some people have suggested that because these policies protect wetlands that will eventually be inundated, the prospect of sea level rise is a justification for relaxing wetland protection requirements. However, even from the narrow perspective of a particular parcel of land, this justification ignores the biological productivity that these wetlands can provide until they are inundated, as well as the value of submerged aquatic vegetation that could develop after they are inundated. Moreover, from the broader perspective, even if particular parcels are flooded, society has options for ensuring the continued survival of wetland communities as sea level rises, such as allowing them to migrate inland or promoting their vertical accretion. By protecting today's wetlands, existing programs are helping to keep those options open. 


\section{TABLE OF CONTENTS}

Chapter 1

SEA LEVEL RISE AND WETLAND LOSS: AN OVERVIEW

James G. Titus

Introduction

Basis for Expecting a Rise in Sea Level .............................................................. 3

Natural Impacts of Sea Level Rise ........................................................................ 10

Human Interference with Nature's Response to Sea Level Rise.........................................18

Nationwide Loss of Wetlands: A First Approximation ...................................................25

Preventing Future Wetland Losses ..............................................................29

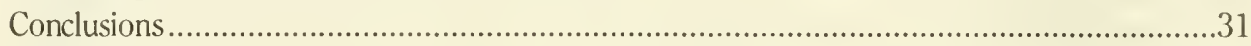

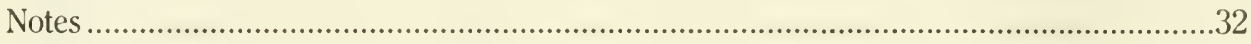

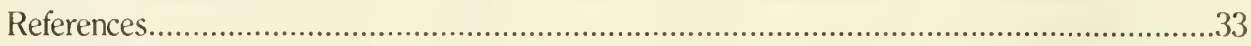

Chapter 2

CHARLESTON CASE STUDY

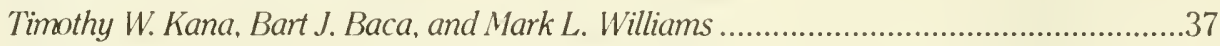

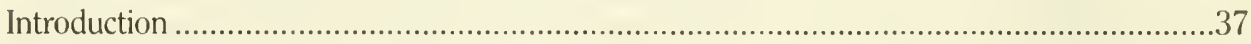

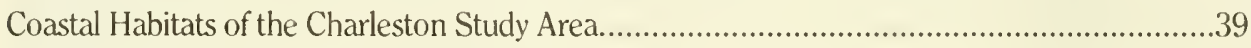

Wetland Transects: Method and Results.................................................................42

Wetland Scenarios for the Charleston Area: Modeling and Results..................................46

Recommendations for Further Study ...................................................................51

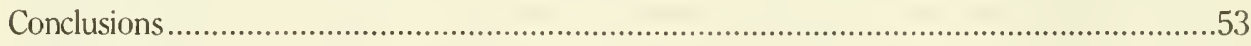

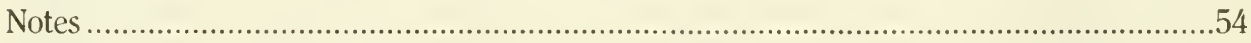

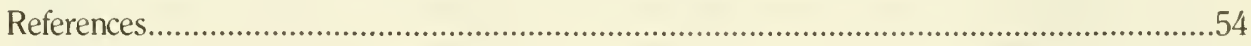

Chapter 3

NEW JERSEY CASE STUDY

Timothy W. Kana, William C. Eiser, Bart J. Baca, and Mark L. Williams..........................61

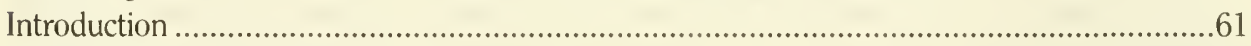

Characteristics of the Study Area ........................................................................61

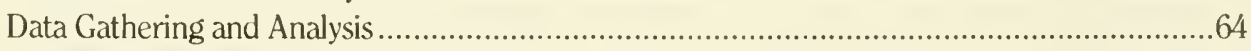

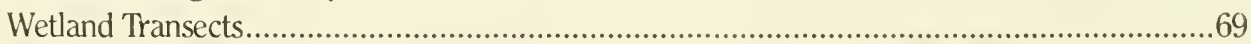

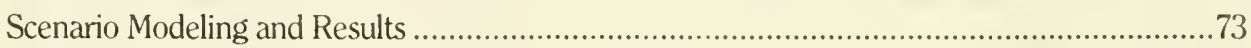

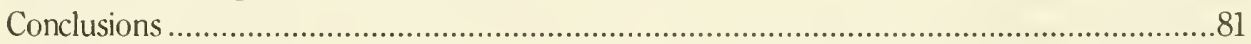

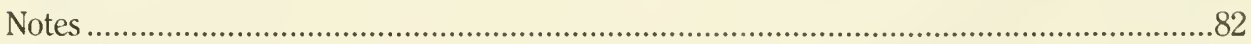

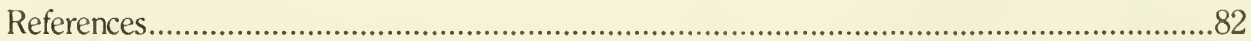




\section{Chapter 4}

\section{IMPACTS ON COASTAL WETLANDS THROUGHOUT THE UNITED STATES}

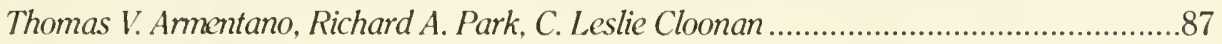

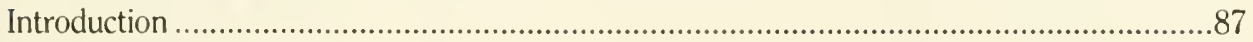

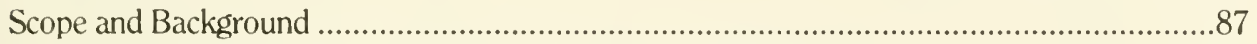

Regional Wetland Differences Relevant to Sea Level Adjustments ......................................8

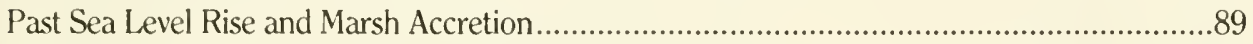

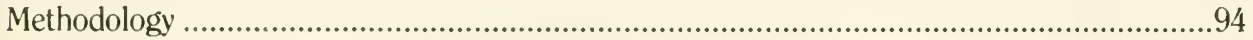

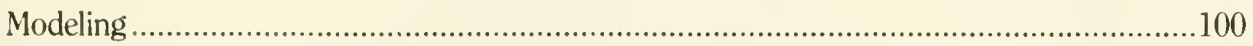

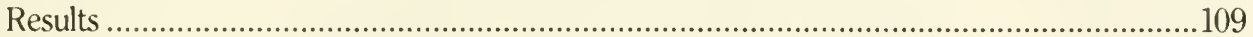

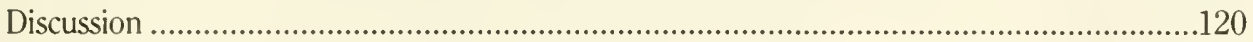

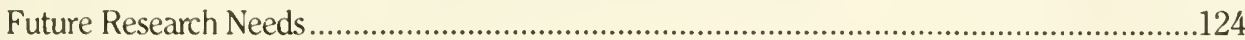

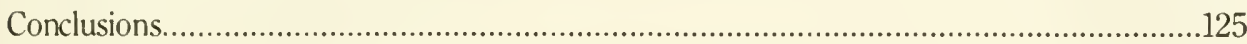

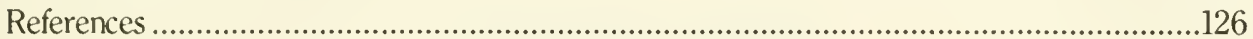

\section{Chapter 5}

ALTERNATIVES FOR PROTECTING COASTAL WETLANDS FROM THE RISING SEA Office of Wetland Protection, U.S. Environmental Protection Agency. 



\title{
SEA LEVEL RISE AND WETLAND LOSS: AN OVERVIEW
}

\author{
by \\ James G. Titus \\ Office of Policy Analysis \\ U.S. Environmental Protection Agency \\ Washington, D.C. 20460
}

\section{INTRODUCTION}

Along the Atlantic and Gulf coasts of the United States, beyond the reach of the ocean waves, lies a nearly unbroken chain of marshes and swamps. Part land and part water, our coastal "metlands" support both terrestrial and aquatic animals, and boast biological productivities far greater than found on dry land.

Many birds, alligators, and turtles spend their entire lifetimes commuting between wetlands and adjacent bodies of water, while land animals that normally occupy dry land visit the wetlands to feed. Herons, eagles, sandpipers, ducks, and geese winter in marshes or rest there while migrating. The larvae of shrimp, crab, and other marine animals find shelter in the marsh from larger animals. Bluefish, flounder, oysters, and clams spend all or part of their lives feeding on other species supported by the marsh. Some species of birds and fish may have evolved with a need to find a coastal marsh or swamp anywhere along the coast (Teal and Teal 1969). Wetlands also act as cleansing mechanisms for ground and surface waters.

The importance of coastal wetlands was not always appreciated. For over three centuries, people have drained and filled marshes and swamps to create dry land for agriculture and urban development. Flood control levees and navigation channels have prevented fresh water, nutrients, and sediment from reaching wetlands, resulting in their conversion to open water. Marshes have often been used as disposal sites for channel dredging, city dumps, and hazardous waste sites.

In the 1960s, however, the public began to recognize the importance of environmental quality in general and these ecosystems. In 1972, the U.S. Congress added Section 404 to the federal Clean Water Act, which strengthened the requirement that anyone wishing to fill a coastal wetland obtain a permit from the Army Corps of Engineers, and added the requirement of approval by the Environmental Protection Agency. Several coastal states enacted legislation to sharply curtail destruction of coastal wetlands.

These restrictions have substantially reduced conversion of wetlands to dry land in coastal areas. The rate of coastal wetland loss declined from 1000 to 20 acres per year in Maryland (Redelfs 1983), from 3100 to 50 acres per year in New Jersey (Tiner 1984), and from 444 to 20 acres per year in Delaware (Hardisky and Klemas 1983). The rate of conversion to dry land in South Carolina has been reduced to about 15 acres per year (South Carolina Coastal Council 1985). ${ }^{1}$ 
Nevertheless, these restrictions have not curtailed the conversion of wetlands to water. The majority of coastal wetland loss in the United States is now taking place in Louisiana, which loses fifty square miles of wetlands per year, mostly to open water. Navigation channels, canals, and flood control levees have impeded the natural mechanisms that once enabled the wetiands of the Mississippi Delta to keep pace with subsidence and rising sea level. The majority of coastal wetland loss in South Carolina results from impoundments that have converted wetlands to open water during part of the year. ${ }^{2}$

In the next century, moreover, conversion of wetlands to open water may overshadow conversion to dry land throughout the coastal zone of the United States. Increasing concentrations of carbon dioxide and other gases are expected to warm our planet a few degrees Celsius (C) by a mechanism commonly known as the "greenhouse effect." Such a warming could raise sea level one meter or so by expanding ocean water, melting mountain glaciers, and causing polar ice sheets to melt or slide into the oceans. Because most of America's coastal wetlands are less than one meter above sea level, a large fraction of our coastal wetlands could be threatened by such a rise.

Offsetting this potential threat are two compensating factors. A rise in sea level would flood areas that are now dry land, creating new wetlands. Moreover, wetlands can grow upward by accumulating sediment and organic material. The potential of these two factors to prevent a major loss of wetlands in the next century, however, may be limited. People who have developed the land just inland of today's wetlands may be reluctant to abandon their houses, which new wetland creation would require. Although wetlands have been able to keep pace with the rise in sea level of the last few thousand years, no one has demonstrated that they could generally keep pace with an accelerated rise.

This report examines the vulnerability of U.S. coastal wetlands (excluding Alaska and Hawaii) to a possible rise in sea level of one or two meters through the year 2100. By coastal wetlands, we refer to marshes, swamps, and other plant communities that are flooded part, but not all, of the time, and that are hydraulically connected to the sea. This chapter, written for the general reader, summarizes the other chapters and their implications, as well as the basis for expecting a global warming and rise in sea level; nature's response to a rising sea; the impacts of human interference with the mechanisms by which wetlands adjust to sea level rise; and policies that might limit future loss of coastal wetlands.

Chapters 2 (Kana, Baca, \& Williams) and 3 (Kana, Eiser, Baca \& Williams) describe field surveys that were used to estimate the potential impacts of sea level rise on wetlands in the area of Charleston, South Carolina, and Long Beach Island, New Jersey, respectively. In Chapter 4, Armentano, Park, \& Cloonan use topographic maps to estimate the potential loss for 52 regions throughout the United States. Finally, in Chapter 5, EPA's Office of Wetland Protection responds to the challenges presented in the preceding chapters.

This report leaves unanswered many questions that will need to be investigated for society to rationally respond to the implications of a substantial rise in sea level: What portion of our wetlands will be able to keep pace with rising sea level? In how many areas would it be economical for communities to hold back the sea by erecting levees and bulkheads, at the expense of their wetlands? Should wetland protection policies seek to slow an inevitable loss of coastal marshes and swamps, or to ensure that a particular fraction of wetlands are maintained in perpetuity?

We hope that this report will stimulate the additional research and policy analysis necessary for society to rationally respond to the risk of wetland loss caused by a rise in sea level. 


\section{THE BASIS FOR EXPECTING A RISE IN SEA LEVEL}

\section{Past Changes in Climate and Sea Level}

Throughout geologic history, sea level has risen and fallen by over three hundred meters (one thousand feet). Although changes in the size and shape of the oceans' basins have played a role over very long periods of time (Hays and Pitman 1973), the most important changes in sea level have been caused by changes in climate. During the last ice age (18,000 years ago), for example, the earth was about five degrees Celsius colder than today, glaciers covered most of the northern hemisphere, and sea level was one hundred meters (three hundred feet) lower than it is today (Donn, Farrand, and Ewing 1962).

Although most of the glaciers have melted since the last ice age, polar glaciers in Greenland and Antarctica still contain enough water to raise sea level more than seventy meters (over two hundred feet) (Untersteiner 1975). A complete melting of these glaciers has not occurred in the last two million years, and would take tens of thousands of years even if the earth warmed substantially. However, unlike the other glaciers, which rest on land, the West Antarctic Ice Sheet rests in the ocean and is thus more vulnerable. Warmer ocean water would be more effective than warmer air at melting glaciers and could melt the ice shelves that prevent the entire glacier from sliding into the oceans. Mercer (1970) suggests that the West Antarctic Ice Sheet completely disappeared during the last interglacial period (which was one or two degrees warmer than today and occurred 100,000 years ago), at which time sea level was five to seven meters (about twenty feet) above its present level.

Over periods of decades, climate can influence sea level by heating and thereby expanding (or cooling and contracting) sea water. In the last century, tidal gauges have been available to measure relative sea level in particular locations. Along the Atlantic Coast, sea level has risen about 30 centimeters (one foot) in the last century (Hicks, Debaugh, and Hickman 1983). Studies combining tide gauge measurements around the world have concluded that average global sea level has risen ten to fifteen centimeters (four to six inches) in the last one hundred years (Barnett 1983; Gomitz, Lebedeff, and Hansen 1982). About five centimeters of this rise can be explained by the thermal expansion of the upper layers of the oceans resulting from the observed global warming of $0.4^{\circ} \mathrm{C}$ in the last century (Gornitz, Lebedeff, and Hansen 1982). Meltwater from mountain glaciers has contributed two to seven centimeters since 1900 (Meier 1984). Figure 1-1 shows that global temperature and sea level appear to have risen in the last century. Nevertheless, questions remain over the magnitude and causes of sea level rise in the last century.

\section{The Greenhouse Effect and Future Sea Level Rise}

Concern about a possible acceleration in the rate of sea level rise stems from measurements showing the increasing concentrations of carbon dioxide $\left(\mathrm{CO}_{2}\right)$, methane, chlorofluorocarbons, and other gases released by human activities. Because these gases absorb infrared radiation (heat), scientists generally expect the earth to warm substantially. Although some people have suggested that unknown or unpredictable factors could offset this warming, the National Academy of Sciences (NAS) has twice reviewed all the evidence and concluded that the warming will take place. In 1979, the Academy concluded: "We have tried but have been unable to find any overlooked physical effect that could reduce the currently estimated global warming to negligible proportions" (Charney 1979). In 1982, the NAS reaffirmed its 1979 assessment (Smagorinsky 1982).

A planet's temperature is determined primarily by the amount of sunlight it receives, the amount of sunlight it reflects, and the extent to which its atmosphere retains heat. When sunlight strikes the earth, it warms the surface, which then reradiates the heat as infrared radiation. However, water vapor, $\mathrm{CO}_{2}$, and other gases in the atmosphere absorb some of the radiation 

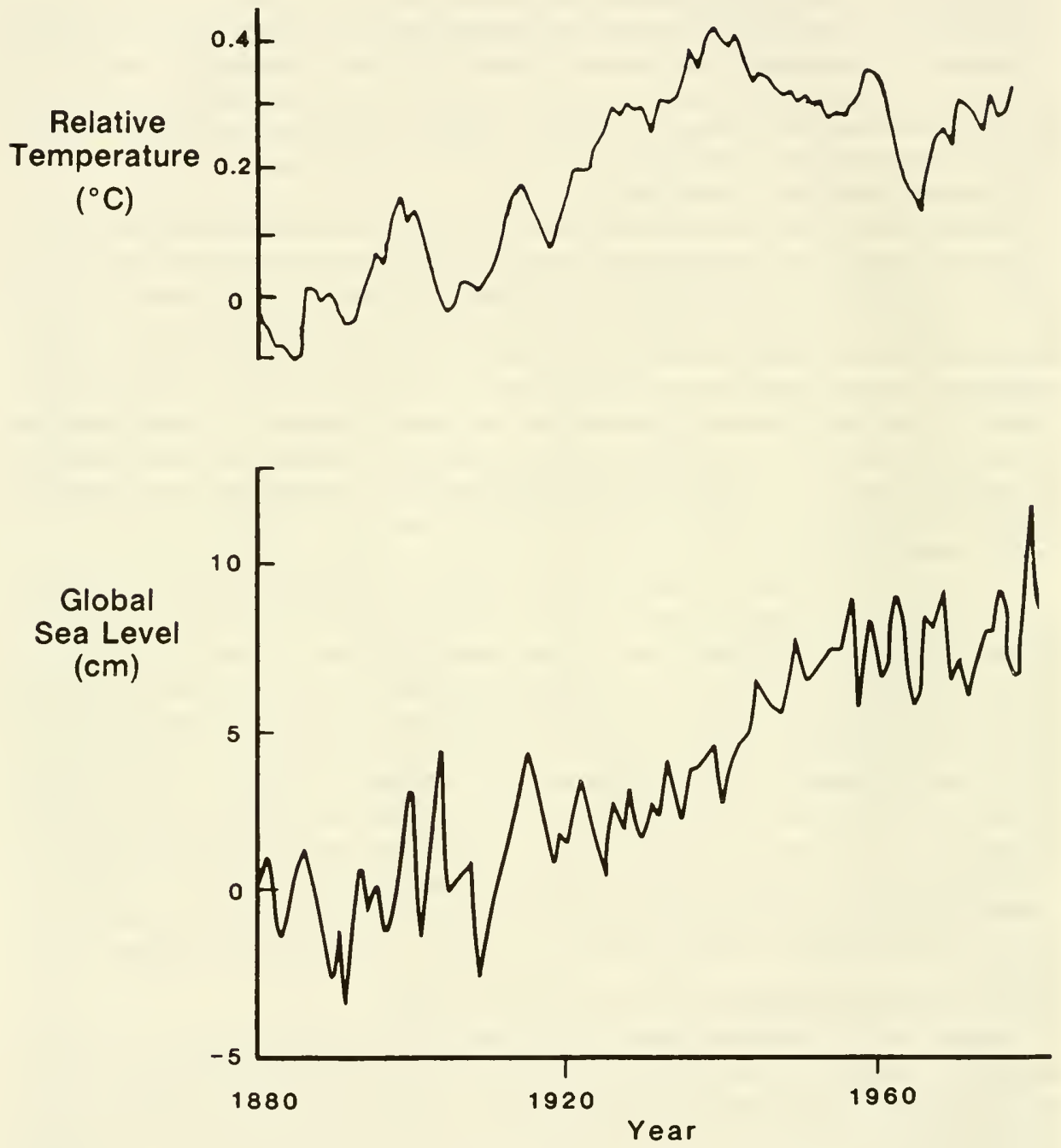

Sources: Temperature curve from: HANSEN, J.E., D. JOHNSON, A. LACIS, S. LEBEDEFF, D. RIND, AND G. RUSSELL, 1981. Climate Impact of Increasing Atmospheric Carbon Dioxide, Science 213:957-966. Sea level curve adapted from: GORNITZ, V., S. LEBEDEFF, and J. HANSEN, 1982. Global Sea Level Trend in the Past Century. Science 215:1611-1614. 
rather than allowing it to pass undeterred through the atmosphere to space. Because the atmosphere traps heat and warms the earth in a manner somewhat analogous to the glass panels of a greenhouse, this phenomenon is generally known as the "greenhouse effect." Without the greenhouse effect of the gases that occur in the atmosphere naturally, the earth would be approximately $33^{\circ} \mathrm{C}\left(60^{\circ} \mathrm{F}\right)$ colder than it is currently (Hansen et al. 1984).

In recent decades, the concentrations of "greenhouse gases" have been increasing. Since the industrial rewolution, the combustion of fossil fuels, deforestation, and cement manufacture have released enough $\mathrm{CO}_{2}$ into the atmosphere to raise the atmospheric concentration of carbon dioxide by 20 percent. As Figure 1-2 shows, the concentration has increased 8 percent since 1958 (Keeling, Bacastow, and Whorf 1982). ${ }^{3}$ Recently, the concentrations of methane, nitrous oxide, chlorofluorocarbons, and a few dozen other trace gases that also absorb infrared radiation have also been increasing (Lacis et al. 1981). Ramanathan et al. (1985) estimate that in the next fifty years, these gases will warm the earth as much as the increase in $\mathrm{CO}_{2}$ alone.

Although there is no doubt that the concentration of greenhouse gases is increasing, the future rate of that increase is uncertain. A recent report by the National Academy of Sciences (NAS) examined numerous uncertainties regarding future energy use patterns, economic growth, and the extent to which $\mathrm{CO}_{2}$ emissions remain in the atmosphere (Nordhaus and Yohe 1983). The Academy estimated a 98 percent probability that $\mathrm{CO}_{2}$ concentrations will be at least 450 parts per million (1.5 times the year-1900 level) and a 55 percent chance that the concentration will be 550 parts per million by 2050 . The Academy estimated that the probability of a doubling of $\mathrm{CO}_{2}$ concentrations by 2100 is 75 percent. Other investigators had estimated that a doubling is likely by 2050 (Wuebbles, MacCracken, and Luther 1984).

If the impact of the trace gases continues to be equal to the impact of $\mathrm{CO}_{2}$, the NAS analysis implies that the "effective doubling" of all greenhouse gases has a 98 percent chance of occurring by $2050{ }^{4}$ An international conference of scientists recently estimated that an effective doubling by 2030 is likely (UNEP, WMO, ICSU 1985). However, uncertainties regarding the emissions of many trace gases are greater than those for $\mathrm{CO}_{2}$. Although the sources of chlorofluorocarbons (CFCs) are well known, future emissions involve regulatory uncertainties. Because these gases can cause deterioration of stratospheric ozone, forty nations have tentatively agreed to cut emissions of the most important CFCs by 50 percent. However, additional cutbacks may be implemented, and other nations may sign the treaty; on the other hand, emissions of gases not covered by the treaty may increase.

Considerable uncertainty also exists regarding the impact of a doubling of greenhouse gases. Physicists and climatologists generally agree that a doubling would directly raise the earth's average temperature by about $1{ }^{\circ} \mathrm{C}$ if nothing else changed. However, if the earth warmed, many other aspects of climate would be likely to change, probably amplifying the direct effect of the greenhouse gases. These indirect impacts are known as "climatic feedbacks."

Figure 1-3 shows estimates by Hansen et al. (1984) of the most important known feedbacks. A warmer atmosphere would retain more water vapor, which is also a greenhouse gas, and would warm the earth more. Snow and floating ice would melt, decreasing the amount of sunlight reflected to space, causing additional warming. Although the estimates of other researchers differ slightly from those of Hansen et al., climatologists agree that these two feedbacks would amplify the global warming from the other greenhouse gases. However, the impact of clouds is far less certain. Although recent investigations have estimated that changes in cloud height and cloud cover would add to the warming, the possibility that changes in cloud cover would offset part of the warming cannot be ruled out. After evaluating the evidence, two panels of the National Academy of Sciences concluded that the eventual warming from a doubling of greenhouse gases would be between $1.5^{\circ}$ and $4.5^{\circ} \mathrm{C}\left(3^{\circ}-8^{\circ} \mathrm{F}\right)$ (Charney et al. 1979; Smagorinsky 1982). 

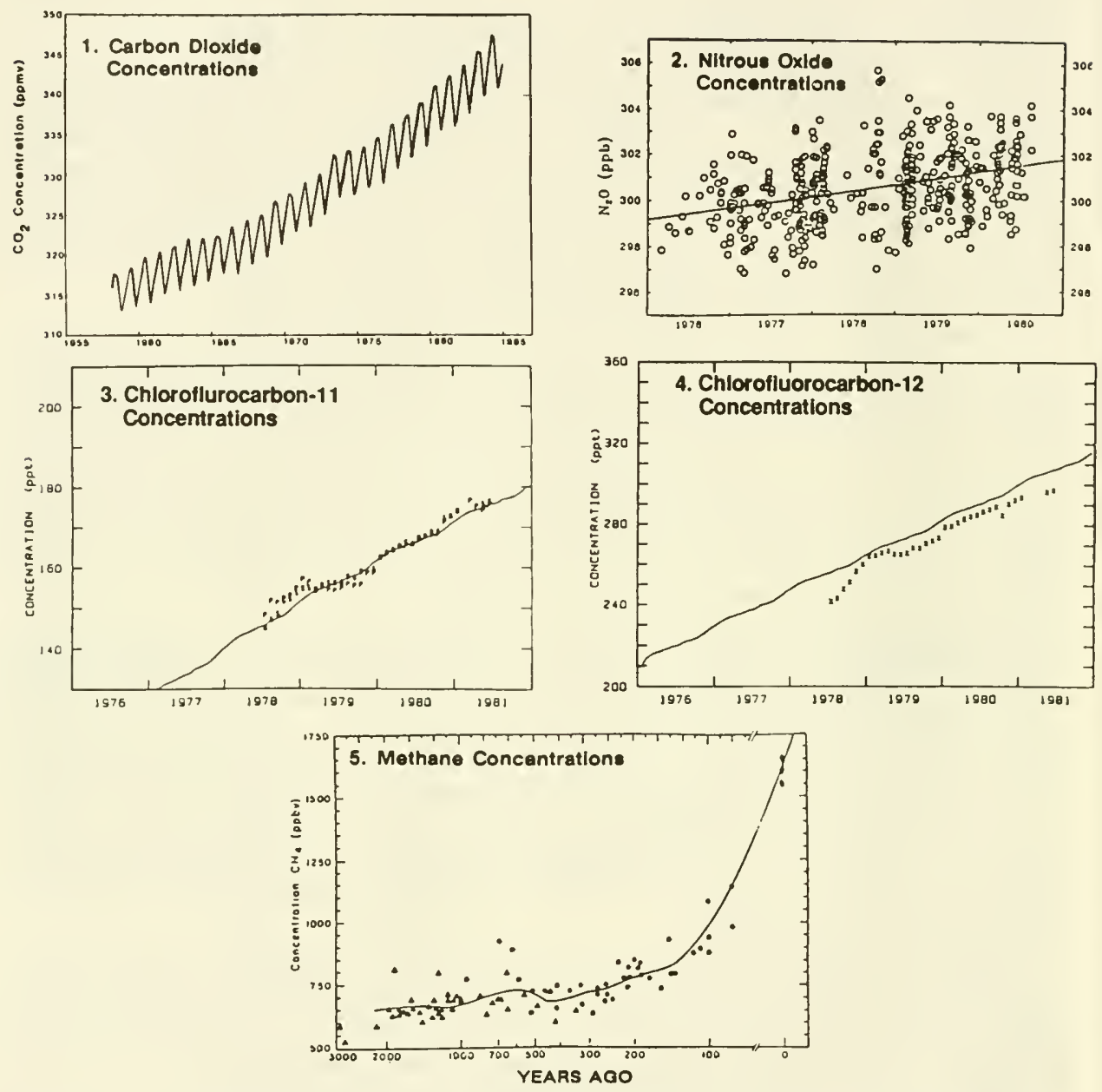

1. Keeling, C.D., R.B. Bacastow, and T.P. Whorf, 1982. Measurements of the Concentration of Carbon Dioxide at Mauna Loa, Hawaii. Carbon Dioxide Review 1982, edited by W. Clark. New York: Oxford University Press, 377-382. Unpublished data from NOAA after 1981.

2. Weiss, R.F., 1981. "The Temporal and Spatial Distribution of Tropospheric Nitrous Oxide." Journal of Geophysical Research. 86(C8):7185-95.

3. Cunnold, D.M., et al., 1983a. The Atmospheric Lifetime Experiment. 3. Lifetime Methodology and Application to Three Years of CFCL3 Data. Journal of Geophysical Research. 88(C13):8401-8414.

4. Cunnold, D.M., et al., 1983b. The Atmospheric Lifetime Experiment. 4. Results for CF2CL2 Based on Three Years Data, Journal of Geophysical Research. 88(C13):8401-8414.

5. Rasmussen, R.A., and M.A.K. Khalil, 1984. Atmospheric Methane in the Recent and Ancient Atmospheres: Concentrations, Trends, and Interhemispheric Gradient, Journal of Geophysical Research. 89(D7): 11599-605. 


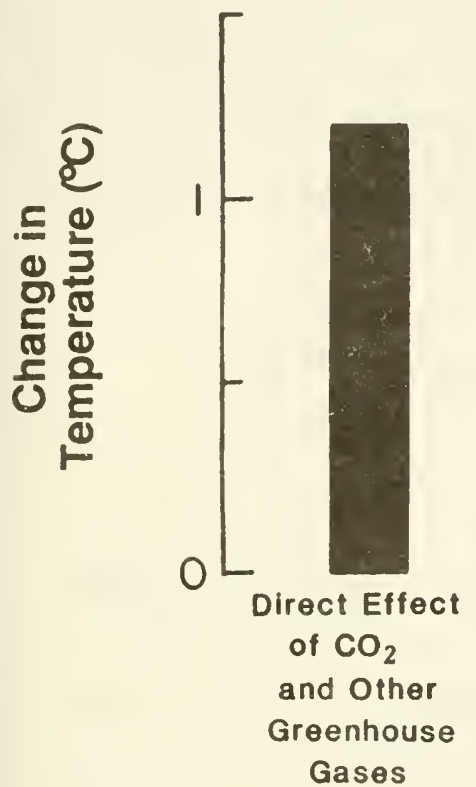

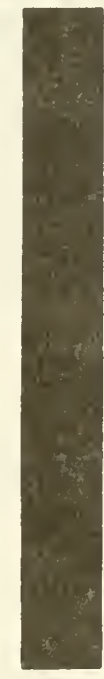

Water
Vapor Feedback

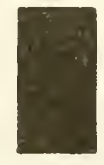

Decreased Reflectivity

Due to

Retreat of

Ice and

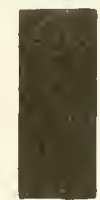

Cloud Height

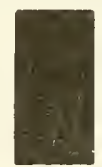

Cloud Cover

NOTE: Although Hansen et al. estimate a positive feedback from the clouds, a negative feedback cannot be ruled out.

Sources: Adapted from: HANSEN, J.E., A. LACIS, D. RIND, and G. RUSSELL, 1984. Climate Sensitivity to Increasing Greenhouse Gases. In Greenhouse Effect and Sea Level Rise: A Challenge for This Generation, edited by M.C. Barth and J.G. Titus. New York: Van Nostrand Reinhold, p. 62.

A global warming could raise sea level by expanding ocean water, melting mountain glaciers, and causing ice sheets in Greenland and Antarctica to melt or slide into the oceans. Four major reports have assessed the possible significance of these factors, as shown in Table 1-1 and Figure 1-4. All predict that the global warming will cause the rate of sea level rise to accelerate.

Revelle (1983) estimated that Greenland and mountain glaciers could each contribute $12 \mathrm{~cm}$ to sea level in the next century, and that thermal expansion could contribute $30 \mathrm{~cm}$. Based on current trends, Revelle concluded that other factors could contribute an additional $16 \mathrm{~cm}$, for a total rise of $70 \mathrm{~cm}$, plus or minus 25 percent. Hoffman et al. (1983) developed a variety of sea level rise scenarios based on high and low assumptions for all the major uncertainties. They estimated that sea level was most likely to rise between 26 and $39 \mathrm{~cm}$ by 2025 and 91 to $137 \mathrm{~cm}$ by 2075 . 
The National Academy of Sciences Polar Research Board Report Glaciers, Ice Sheets, and Sea Level (Meier et al. 1985) examined the possible glacial contribution to sea level rise by the year 2100. The panel endorsed estimates that alpine (Meier 1984) and Greenland (Bindschadler 1985) glaciers would each contribute 10 to 30 centimeters. Thomas (1985) estimated that the antarctic contribution resulting from a four-degree warming would most likely be $28 \mathrm{~cm}$, but could be as high as 2.2 meters. However, the panel concluded that the antarctic contribution could be anywhere from a 10-centimeter drop (due to increased snowfall) to a one-meter rise.

Hoffman et al. (1986) revised their earlier projections in light of the glacial process models developed in the Polar Board report and new information on future concentrations provided by Nordhaus and Yohe (1983) and Ramanathan et al. (1985). Although the revised assumptions had a minor impact on their estimates of thermal expansion, it substantially lowered their estimates of snow and ice contributions until after 2050. They estimated the rise by 2025 to be between 10 and $21 \mathrm{~cm}$, and by 2075 to be between 36 and $191 \mathrm{~cm} .{ }^{5}$ Thomas (1986) estimated the likely rise through 2100 to be 64 to $230 \mathrm{~cm}$.

\section{TABLE 1-1}

\section{ESTIMATES OF FUTURE SEA LEVEL RISE (centimeters)}

\begin{tabular}{|c|c|c|c|c|c|c|}
\hline & $\begin{array}{c}\text { Thermal } \\
\text { Expansion }\end{array}$ & $\begin{array}{c}\text { Alpine } \\
\text { Glaciers } \\
\end{array}$ & \multicolumn{2}{|c|}{ Greenland } & Antarctica & Total \\
\hline Revelle (1983) & 30 & 12 & \multicolumn{2}{|c|}{12} & a & 70 \\
\hline $\begin{array}{l}\text { Hoffman et al. } \\
\qquad(1983)\end{array}$ & $28-115$ & $\mathrm{~b}$ & \multicolumn{2}{|c|}{$\mathrm{b}$} & $\mathrm{b}$ & $56-345$ \\
\hline $\begin{array}{l}\text { Meier et al. } \\
\text { (1985) }\end{array}$ & -- & $10-30$ & \multicolumn{2}{|c|}{$10-30$} & $-10-+100$ & $50-200^{C}$ \\
\hline $\begin{array}{l}\text { Hoffman et al. } \\
\quad(1986)\end{array}$ & $28-83$ & $12-37$ & \multicolumn{2}{|c|}{$6-27$} & $12-220$ & $57-368$ \\
\hline Thomas (1986) & $28-70$ & $14-35$ & \multicolumn{2}{|c|}{$9-45$} & $13-80$ & $64-230$ \\
\hline \multicolumn{7}{|c|}{ Total Rise in Specific Years: ${ }^{d}$} \\
\hline & $\underline{2000}$ & $\underline{2025}$ & 2050 & $\underline{2075}$ & $\underline{2085}$ & $\underline{2100}$ \\
\hline Revelle (1983) & -- & -- & -- & -- & 70 & -- \\
\hline $\begin{array}{l}\text { Hoffman et al. } \\
\text { low } \\
\text { mid-range low } \\
\text { mid-range high } \\
\text { high }\end{array}$ & $983) \begin{array}{r}4.8 \\
8.8 \\
13.2 \\
17.1\end{array}$ & $\begin{array}{l}13 \\
26 \\
39 \\
55\end{array}$ & $\begin{array}{r}23 \\
53 \\
79 \\
117\end{array}$ & $\begin{array}{r}38 \\
91 \\
137 \\
212\end{array}$ & $\begin{array}{l}-- \\
-- \\
-- \\
--\end{array}$ & $\begin{array}{r}56.0 \\
144.4 \\
216.6 \\
345.0\end{array}$ \\
\hline $\begin{array}{l}\text { Hoffman et al. } \\
\text { low } \\
\text { high }\end{array}$ & $\begin{array}{r} \\
3.5 \\
5.5\end{array}$ & $\begin{array}{l}10 \\
21\end{array}$ & $\begin{array}{l}20 \\
55\end{array}$ & $\begin{array}{r}36 \\
191\end{array}$ & $\begin{array}{r}44 \\
258\end{array}$ & $\begin{array}{r}57 \\
368\end{array}$ \\
\hline
\end{tabular}

a Revelle attributes $16 \mathrm{~cm}$ to other factors.

$b$ Hoffman et al. (1983) assumed that the glacial construction would be one to two times the contribution of thermal expansion.

c This estimate includes extrapolation of thermal expansion from Revelle (1983).

$d$ Only Hoffman et al. made year-to-year projections for the next century. 


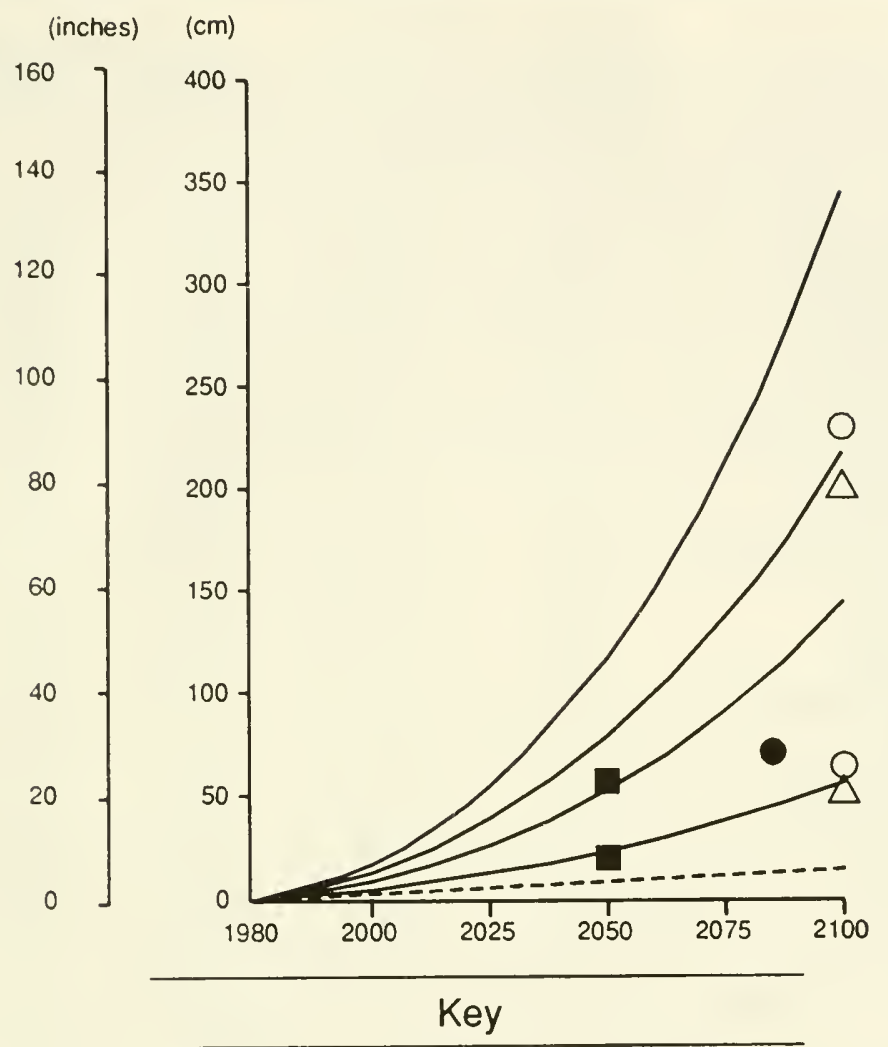

\footnotetext{
- - Current Trend

EPA high, mid-high, mid-low, and low scenarios (Hottman et al. 1983)

- Hoffman et al. (1986) high and low estimates

- NAS estimate (Revelle 1983)

$\triangle \quad$ Polar Research Board high and low estimates (Meier et al. 1985)

Thomas (1986) high and low estimates
}

Note: The EPA 1983 Mid-Low and Mid-High scenarios are called "low" and "high" for the remainder of this chapter and throughout Chapters 2, 3, and 4.

In this study, we examine the implications of the mid-low and mid-high scenarios from Hoffman et al. (1983), shown in Table 1-1 and Figure 1-4. (For simplicity, we call these scenarios "low" and "high.") Although it might be desirable to undertake a worst-case analysis of a larger rise, the scenarios we used are broadly representative of the studies that have been undertaken so far. Because much of the U.S. coast is sinking, the relative rise at a particular location will generally be greater. Table 1-2 lists the expected rise in sea level under the low and high scenarios for different areas of the United States. 
IVE SEA LEVEL RISE IN THE UNITED STATES

\begin{tabular}{|c|c|c|c|c|}
\hline & $\begin{array}{c}\text { Historic } \\
\text { Subsidence } \\
\text { Rate } \\
(\mathrm{mm} / \mathrm{yr})\end{array}$ & $\begin{array}{l}\text { Historic } \\
\text { Relative } \\
\text { Sea Level } \\
\text { Trend } \\
(\mathrm{mm} / \mathrm{yr})\end{array}$ & $\begin{array}{l}\text { Low } \\
\text { Scenario } \\
1980-2100 \\
(\mathrm{~cm})\end{array}$ & $\begin{array}{c}\text { High } \\
\text { Scenario } \\
1980-2100 \\
(\mathrm{~cm})\end{array}$ \\
\hline Portland, Maine & 1.1 & 2.3 & 157.6 & 229.8 \\
\hline Boston, Massachusetts & 1.1 & 2.3 & 157.6 & 229.8 \\
\hline Newport, Rhode Is land & 1.4 & 2.6 & 161.2 & 233.4 \\
\hline New London, Connecticut & 1.0 & 2.2 & 156.4 & 228.6 \\
\hline New York, New York & 1.6 & 2.8 & 163.6 & 235.8 \\
\hline Sandy Hook, New Jersey & 3.0 & 4.2 & 186.4 & 252.6 \\
\hline Atlantic City, New Jersey & 2.8 & 4.0 & 178.0 & 250.2 \\
\hline Philadelphia, Pennsylvania & 1.4 & 2.6 & 161.2 & 233.4 \\
\hline Baltimore, Maryland & 2.0 & 3.2 & 168.4 & 240.6 \\
\hline Annapolis, Maryland & 2.5 & 3.7 & 174.4 & 246.6 \\
\hline Hampton Roads, Virginia & 3.1 & 4.3 & 181.6 & 253.8 \\
\hline Charleston, South Carolina & 2.2 & 3.4 & 170.8 & 243.0 \\
\hline Fernandina, Florida & 0.5 & 1.7 & 150.4 & 222.6 \\
\hline Miami Beach, Florida & 1.1 & 2.3 & 157.6 & 229.8 \\
\hline Cedar Key, Florida & 0.8 & 2.0 & 154.0 & 226.2 \\
\hline Pensacola, Florida & 1.2 & 2.4 & 158.8 & 231.0 \\
\hline Eugene Island, Louisiana & 8.8 & 10.0 & 250.0 & 322.2 \\
\hline Galveston, Texas & 5.1 & 6.3 & 205.6 & 277.8 \\
\hline San Diego, California & 0.7 & 1.9 & 152.8 & 225.0 \\
\hline Los Angeles, California & -0.6 & 0.6 & 137.2 & 209.4 \\
\hline San Francisco, California & 0.0 & 1.2 & 144.4 & 216.2 \\
\hline Astoria, Oregon & -1.7 & -0.5 & 124.0 & 196.2 \\
\hline Seattle, Washington & 0.7 & 1.9 & 152.8 & 225.0 \\
\hline Sitke, Alaska & -3.6 & -2.4 & 101.2 & 173.4 \\
\hline Worldwide & 0 & 1.2 & 144.4 & 216.6 \\
\hline
\end{tabular}

Source: Derivations of historic rates of relative sea level rise due to subsidence are based on an assumption of a $1.2 \mathrm{~mm} / \mathrm{yr}$ global rise in sea level. Projections are based on mid-low and mid. high estimates from Hoffman et al. 1983, with historic subsidence (from Hicks, Debaugh, and Hickman 1983) added.

\section{NATURAL IMPACTS OF SEA LEVEL RISE}

There are three major ways by which sea level rise can disrupt wetlands: inundation, erosion, and saltwater intrusion. In some cases, wetlands will be converted to bodies of open water; in other cases, the type of vegetation will change but a particular area will still be wetland. However, if sea level rises slowly enough, the ability of wetlands to grow upward-by trapping sediment or building upon the peat the sediment creates-can prevent sea level rise from disrupting the wetlands.

In explaining potential impacts of sea level rise, we focus on what the impact would be if wetlands did not grow upward, and leave it to the reader to remember that this potential "vertical accretion" can offset these impacts. The actual impact will depend on the "net substrate change," i.e., the difference between sea level rise and wetland accretion. In this report, all estimates of future wetland loss are based on the assumption that current rates of vertical accretion continue. An important area for future research will be to determine whether future climate change and sea level rise will accelerate or slow the rate of wetland accretion. Even if 
wetlands are able to accrete more rapidly in the future, however, existing literature provides little reason to believe that wetlands will generally be able to keep up with a one- or two-meter rise in sea level.

\section{Tidal Flooding}

Because periodic flooding is the essential characteristic of salt marshes, increases in the frequency and duration of floods can substantially alter these ecosystems. Salt marshes extend seaward to roughly the elevation that is flooded at mean tide, and landward to roughly the area that is flooded by spring tide (the highest astronomical tide every 15 days). Salt marsh plants are different from most plants found inland in that they tolerate salt water to varying degrees (Teal and Teal 1969). Coastal wetlands flooded once or twice daily support "low marsh" vegetation, while areas flooded less frequently support high marsh species. Transition wetlands can be found above the high marsh, in areas flooded less frequently than twice a month.

The natural impact of a rising sea is to cause marsh systems to migrate upward and inland. Sea level rise increases the frequency and/or duration of tidal flooding throughout a salt marsh. If no inorganic sediment or peat is added to the marsh, the seaward portions become flooded so much that marsh grass drowns and marsh soil erodes; portions of the high marsh become low marsh; and upland areas immediately above the former spring tide level are flooded at spring tide, becoming high marsh. If nearby rivers or floods supply additional sediment, sea level rise slows the rate at which the marsh advances seaward.

The net change in total marsh acreage depends on the slopes of the marsh and upland areas. If the land has a constant slope throughout the marsh and upland, then the area lost to marsh drowning will be equal to the area gained by the landward encroachment of spring high tides. In most areas, however, the slope above the marsh is steeper than the marsh; so a rise in sea level causes a net loss of marsh acreage. Two extreme examples are noteworthy: marshes immediately below cliffs in New England and along the Pacific Coast could drown without being replaced inland. In Louisiana, thousands of square miles of wetlands are within one meter of sea level, with very narrow ridges in between and very little adjacent upland between one and two meters above sea level. A one-meter rise in sea level could drown most of the wetlands there without necessarily creating any significant new marsh (Louisiana Wetland Protection Panel, 1987; Gagliano et al. 1981).

Figure 1-5 illustrates why there is so much more land at marsh elevation than just above the marsh. Wetlands can grow upward fast enough to keep pace with the slow rise in sea level that most areas have experienced in the recent past (Kaye and Barghoorn 1964; Coleman and Smith 1964; Redfield 1967). Thus, areas that might have been covered with two or three meters of water (or more) have wetlands iristead (Figures 1-5A, 1-5B). If sea level rise accelerates only slightly, marshes that are advancing today may have sufficient sediment to keep pace with sea level. But if sea level rise accelerates to one centimeter per year (projected for 2025-2050), the sea will be rising much more rapidly than the demonstrated ability of wetlands to grow upward in most areas (Armentano et al., Chapter 4) and the increase in wetland acreage of the last few thousand years will be negated (Figure 1-5C). If adjacent upland areas are developed, all the wetlands could be lost (Figure 1-5D).

An important factor in determining the vulnerability of marshes to sea level rise is the tidal range, the difference in elevation between the mean high tide and mean low tide. Coastal wetlands are generally less than one tidal range above mean sea level. ${ }^{6}$ Thus, if the sea rose by one tidal range overnight, all the existing wetlands in an area would drown. Tidal ranges vary greatly throughout the United States. Along the open coast, it is over four meters in Maine, somewhat less than two meters (about five feet) along the mid-Atlantic, and less than one meter (about two feet) in the Gulf of Mexico (NOAA 1985). The shape of an embayment can amplify or dampen the tidal range, however. Most notably, the estuaries behind barrier islands with widely separated inlets can have tidal ranges of thirty centimeters (one foot) or less. The tidal range of Chesapeake Bay is about fifty centimeters (NOAA 1985). 

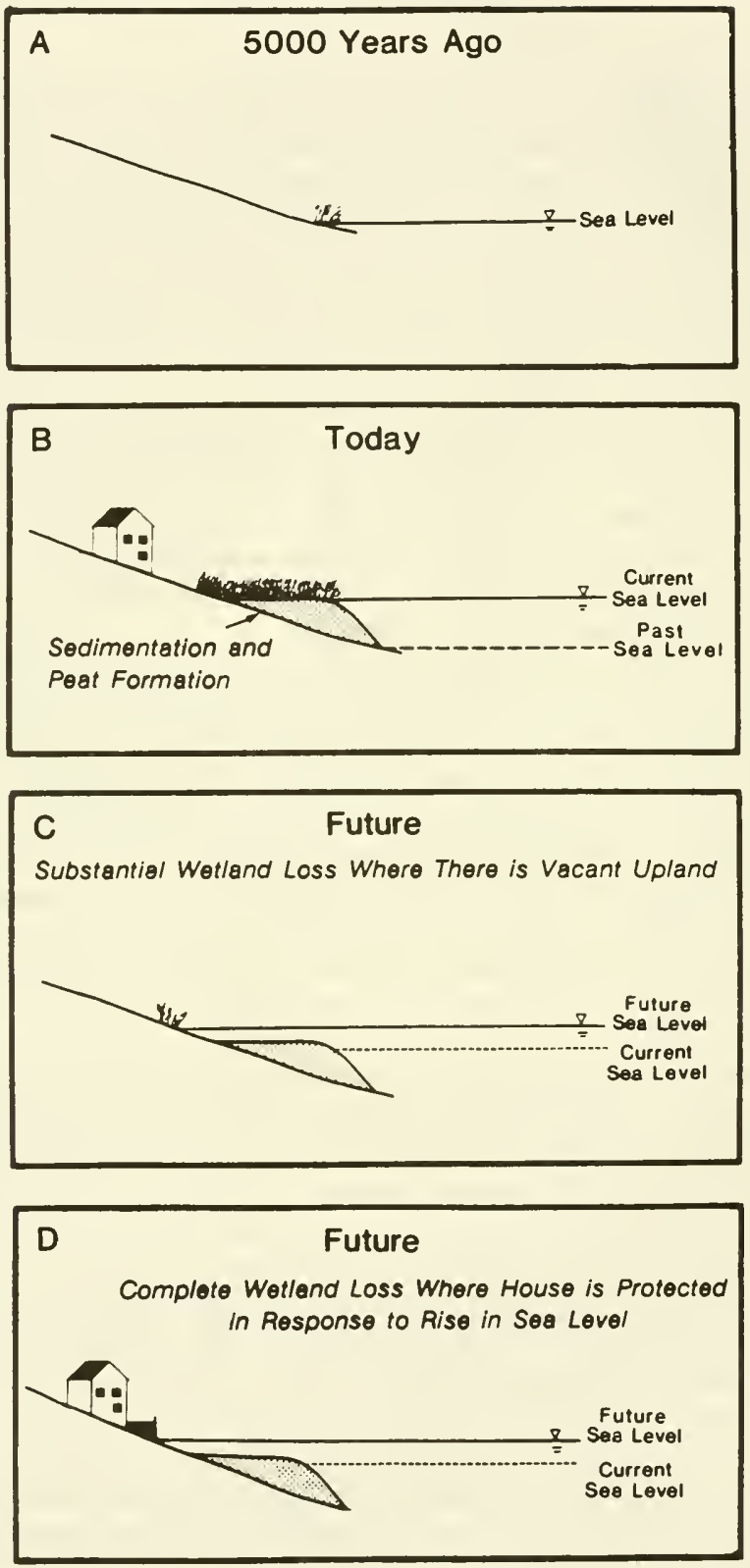

Coastal marshes have kept pace with the slow rate of sea level rise that has characterized the last several thousand years. Thus, the area of marsh has expanded over time as new lands were inundated, resulting in much more wetland acreage than dry land just above the wetlands ( $A$ and $B$ ). If in the future, sea level rises faster than the ability of the marsh to keep pace, the marsh area will contract (C). Construction of bulkheads to protect economic development may prevent new marsh from forming and result in a total loss of marsh in some areas (D). 
To investigate some of these issues, Kana et al. (Chapters 2 and 3) estimate the impact of accelerated sea level rise on wetlands in the areas of Charleston, South Carolina, and Long Beach Island, New Jersey. Charleston has a tidal range of almost two meters, while the New Jersey area has tidal ranges between sixty and one hundred centimeters. In each area, they surveyed a dozen marsh profiles to develop a "composite transect," an average cross section of the marsh. Based on previous studies, they assume that the marshes in both areas could grow upward at a rate of five millimeters per year.

Figure 1-6 illustrates the composite transect of the Charleston marshes. The low marsh, whose elevation is between 45 and 90 centimeters ( 1.5 to 3.0 feet) is 550 meters ( 1800 feet) wide. The high marsh, with elevation between 90 and 120 centimeters ( 3.0 to 4.0 feet), is about 210 meters (700 feet) wide; the transition wetlands, with elevation between 120 and 195 centimeters ( 4.0 to 6.5 feet), are generally about 150 meters (500 feet) wide. Thus, the average slopes found in the low, high, and transition marsh areas are $0.08,0.14$, and 0.50 percent, respectively, confirming that the slope of the profile increases as one moves inland from the marsh. (The slope immediately above the marsh is approximately 0.55 percent.)

\section{FIGURE 1.6}

\section{COMPOSITE TRANSECT-CHARLESTON, S.C.}

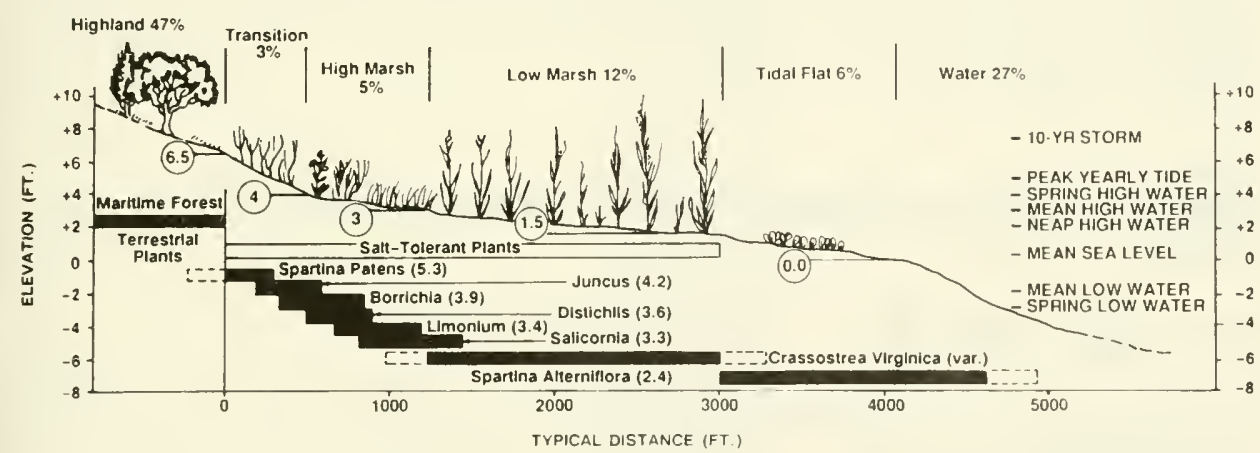

Composite wetlands transect for Charleston illustrating the approximate percent occurrence and modal elevation for key indicator species or habitats based on results of 12 surveyed transects. Minor species have been omitted. Elevations are with respect to 1929 NGVD, which is about 15 $\mathrm{cm}$ lower than current sea level. Current tidal ranges are shown at right.

\section{Source: Kana et al. (Chapter 2)}

A word on what we mean by elevation is in order. Old maps often have contours representing, for example, five feet above sea level. However, because sea level has been rising, a contour that was five feet above sea level fifty years ago may only be four and one-half feet above sea level today. To avoid potential confusion, most maps today express elevations with respect to the "National Geodetic Vertical Datum" (NGVD) reference plane, which is a fixed reference that is unaffected by changes in sea level.

NGVD was developed in 1929 by estimating mean sea level at twenty-six sites along the North American coast for the preceeding couple of decades. For these sites, zero elevation (NGVD) is the same as mean sea level over that period. For other sites, however, the zero elevation is not necessarily mean sea level for that period. NGVD was developed by a surveying 
technique, known as "leveling," between the twenty-six sites; mean sea level, on the other hand, may be higher or lower at a particular location depending on such factors as rainfall, winds, currents, and atmospheric pressure. This distinction is usually unimportant; even USGS topographic maps printed before 1973 refer to elevations above "mean sea level" when they really mean NGVD. For most practical purposes, the reader of this report can assume that zero elevation at a particular site refers to the level of the sea between 1910 and 1929. All elevations in this report are with respect to NGVD unless otherwise stated.

The other type of elevational reference is the "tidal datum." Depending upon context, terms such as "mean sea level" can refer to a theoretical concept or a legal definition. The legal definition of mean sea level (MSL) is the average water level observed at a location over the period 1960-78; mean high water (MHW) and mean low water (MLW) are the averages of all high and low tides, respectively, over that period; mean tidal range is the difference between mean high water and mean low water. However, wetlands respond to actual conditions, the average water level of today. Thus, unless otherwise stated, the term mean sea level in this report refers to the average water levels of today, not the legal tidal datum.

Figure 1-7 illustrates the impact on the composite marsh profile of the low scenario for the period 1980-2075, which implies an 87-centimeter (2.9-foot) rise in relative sea level for the Charleston area. Because Kana et al. assume that sedimentation would enable the surface to rise 48 centimeters, the net rise in sea level is equivalent to an instantaneous rise of 39 centimeters (15 inches). As the figure shows, the area of low and high marsh would each decline by about 50 percent as they shifted upward and inland. For the high scenario rise of 159 centimeters (5.2 feet), the loss would be approximately 80 percent.

\section{FIGURE 1-7 \\ SHIFT IN WETLANDS ZONATION ALONG A SHORELINE PROFILE}

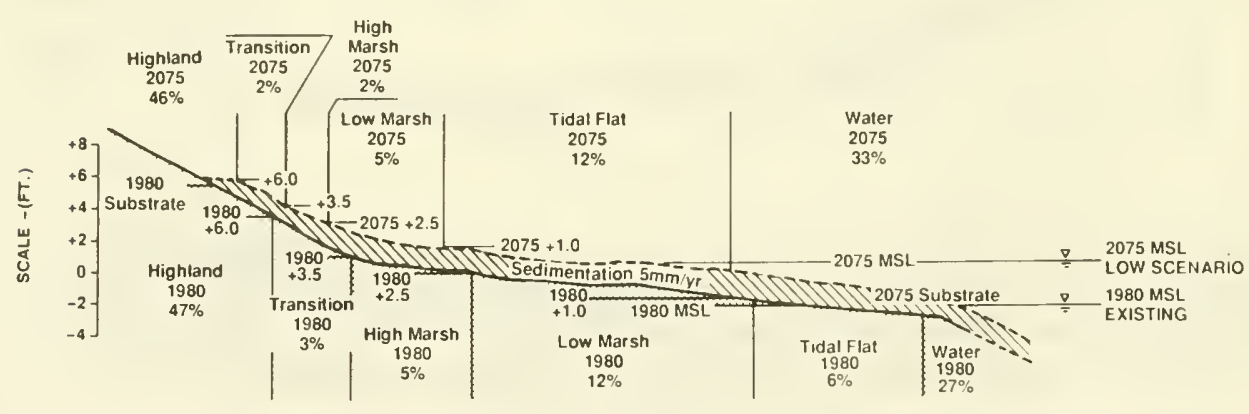

Conceptual model of the shift in wetlands zonation along a shoreline profile if sea level rise exceeds sedimentation by $40 \mathrm{~cm}$. In general, the response will be a landward shift and altered areal distribution of each habitat because of variable slopes at each elevation interval.

Source: Kana et al. (Chapter 2)

Although Kana et al. considered alternative scenarios of sea level rise, they did not investigate alternative rates of wetland accretion. However, using the data presented in Figure 1-6, one can derive Figure 1-8, which shows marsh loss for various combinations of vertical accretion and sea level rise. For example, an 80 percent loss could occur (1) if the marsh grows upward at 1 centimeter per year and sea level rises 1.9 meters by 2100 or (2) if sea level rises 80 centimeters 
and the marsh stops accreting. The shaded region illustrates the most likely range based on current literature: global sea level rise of 50-200 centimeters and accretion of 4-6 millimeters per year. Within this likely range, a negligible loss of wetlands is possible; however, over half the shaded region shows an 80 percent loss of marsh by 2100 .

\section{FIGURE 1-8 \\ PERCENT MARSH LOSS IN THE CHARLESTON AREA BY 2100 FOR COMBINATIONS OF SEA LEVEL RISE AND MARSH ACCRETION}
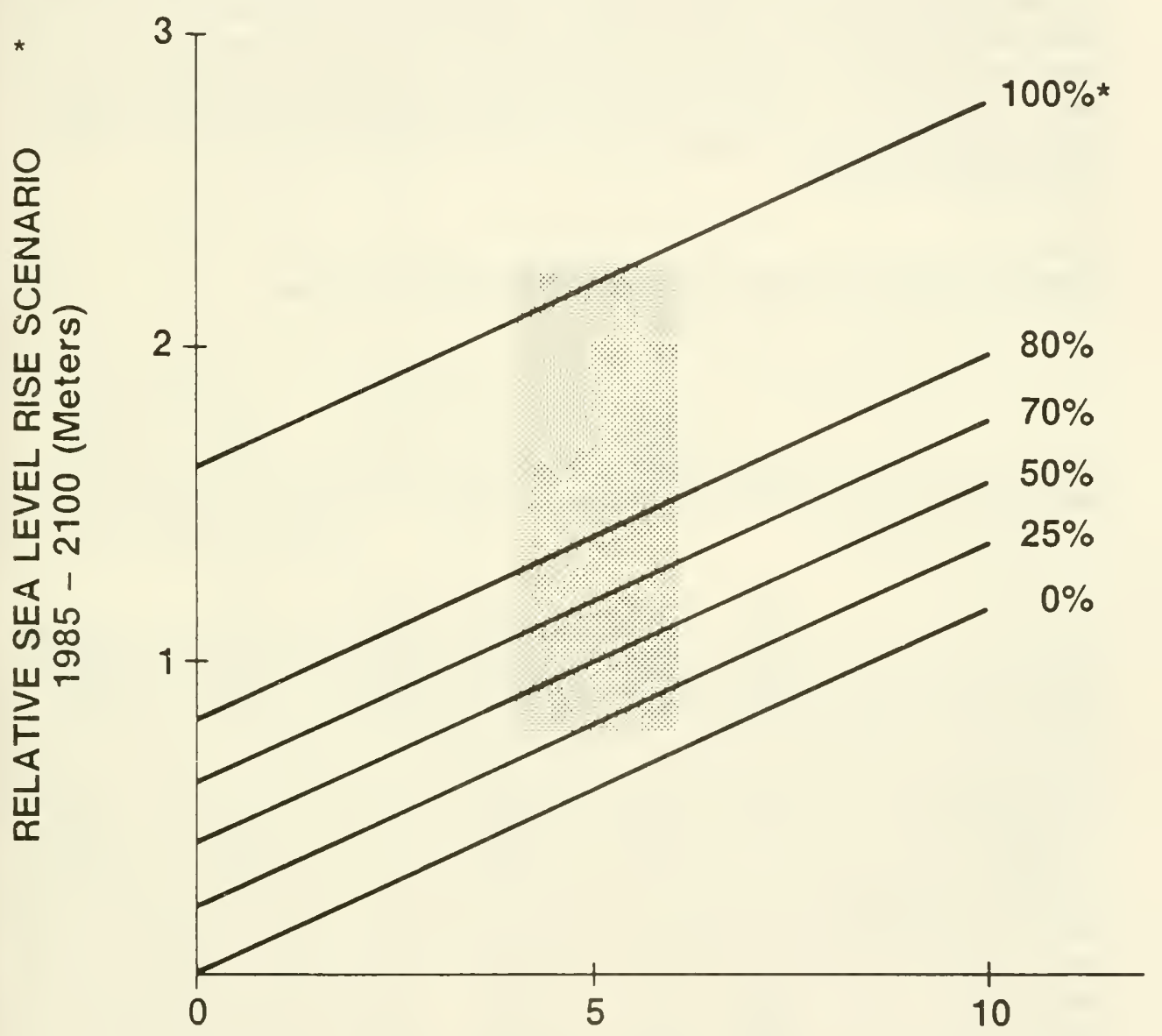

\section{MARSH ACCRETION (Millimeters/Year)}

The shaded area represents the most likely range of sea level rise $150-200 \mathrm{~cm}$, global; $75-225 \mathrm{~cm}$, relative to Charleston) and marsh accretion (4.6 mm/yr).

"Wetland loss in excess of 80 percent occurs only if today's uplands are protected. 
To put the significance of these estimates in perspective, one would expect the Charleston area to lose less than 0.5 percent of its wetlands in the next century if current rates of conversion for development continue. Although a substantial amount of marsh was filled as the city was built, conversion of wetlands to dry land came to a virtual halt with the creation of the South Carolina Coastal Council. Since 1977, the state has lost only 35 of its 500,000 acres to dry land (South Carolina Coastal Council 1985). Impoundments have transformed another 100 acres. ${ }^{7}$ Extrapolating these trends would imply a loss of about 1,500 acres in the next century, about 0.3 percent of the state's coastal wetlands. Thus, sea level rise would be the dominant cause of wetland loss. ${ }^{8}$

In the New Jersey study area, the high marsh dominates. Thus, there would not be a major loss of total marsh acreage for the low scenario through 2075; the high marsh would simply be converted to low marsh. For the high scenario, however, there would be an 86 percent loss of marsh, somewhat greater than the loss in the Charleston area. Table 1-3 illustrates the projected shifts in wetlands for the South Carolina and New Jersey Case studies through the year 2075; Table 14 shows projected changes in marsh area for net rises in sea level (over accretion) ranging from 10 to $100 \mathrm{~cm}$.

TABLE 1-3

IMPACT OF SEA LEVEL RISE ON WETLANDS 1980-2075 (acres)

\begin{tabular}{|c|c|c|c|}
\hline 207 & $\begin{array}{l}2075 \text { Abandonment } \\
\text { (Vacant Land) }\end{array}$ & $\begin{array}{l}\text { Defend } \\
\text { (Bulkh }\end{array}$ & $\begin{array}{l}\text { Shore } \\
\text { eads) }\end{array}$ \\
\hline Cur & $\mathrm{High}$ & Low & $\mathrm{High}$ \\
\hline Tre & Sea Level & Sea Level & Sea Level \\
\hline
\end{tabular}

Charleston Case Study

Transition

High Marsh

Low Marsh

Tidal Flat

Total Marsh

Percent Loss (Gain)

High Marsh

Low Marsh

Marsh

New Jersey Case Study

Transition
High Marsh
Low Marsh
Tidal Flat
Total Marsh
Percent Loss (Gain)
High Marsh
Low Marsh
All Marsh

$\begin{array}{ll}1500 & 2820 \\ 2300 & 3320 \\ 5400 & 3910 \\ 2600 & 2600 \\ 7700 & 7230\end{array}$

1355

690

3235

5020

3925

1420
675
860
1425
1525

1420

860

1425

1525
- (44)

28

- 6

40
49

71

84

80

70

40

49

100

86

90

Source: Kana et al. (Chapters 2 and 3). 
WETLAND AREA AS A PERCENT OF TODAY'S ACREAGE FOR A 10- to 100-cm RISE IN SEA LEVEL IN EXCESS OF VERTICAL ACCRETION*

\begin{tabular}{|c|c|c|c|c|c|c|c|c|c|}
\hline Sea & Char & lestor & - SC & Tuck & erton, & NJ & Grea & $t$ Bay, & NJ \\
\hline $\begin{array}{c}\text { Level } \\
\text { Rise }\end{array}$ & $\begin{array}{l}\text { High } \\
\text { Marsh }\end{array}$ & $\begin{array}{c}\text { Low } \\
\text { Marsh }\end{array}$ & $\begin{array}{l}\text { Total } \\
\text { Marsh }\end{array}$ & $\begin{array}{c}\text { High } \\
\text { Marsh }\end{array}$ & $\begin{array}{c}\text { Low } \\
\text { Marsh }\end{array}$ & $\begin{array}{l}\text { Total } \\
\text { Marsh }\end{array}$ & $\begin{array}{l}\text { High } \\
\text { Marsh }\end{array}$ & $\begin{array}{c}\text { Low } \\
\text { Marsh }\end{array}$ & $\begin{array}{l}\text { Total } \\
\text { Marsh }\end{array}$ \\
\hline $0 \mathrm{~cm}$ & 29.9 & 70.1 & 100.0 & 93.9 & 6.1 & 100.0 & 95.8 & 4.2 & 100.0 \\
\hline 10 & 22.6 & 64.6 & 87.2 & 60.1 & 43.2 & 103.4 & 76.0 & 23.9 & 99.9 \\
\hline 20 & 15.4 & 59.0 & 74.4 & 26.3 & 80.5 & 106.8 & 56.2 & 43.5 & 99.7 \\
\hline 30 & 8.1 & 52.9 & 61.0 & 11.5 & 98.6 & 110.2 & 36.4 & 63.3 & 99.7 \\
\hline 40 & 7.8 & 41.1 & 48.9 & 11.5 & 102.0 & 113.6 & 16.5 & 70.3 & 86.8 \\
\hline 50 & 7.8 & 30.7 & 38.5 & 11.5 & 89.5 & 101.0 & 5.2 & 61.9 & 67.1 \\
\hline 60 & 7.8 & 23.4 & 31.2 & 11.5 & 55.8 & 67.3 & 5.2 & 42.0 & 47.2 \\
\hline 70 & 7.8 & 16.2 & 24.0 & 11.5 & 22.0 & 33.5 & 5.2 & 22.2 & 22.4 \\
\hline 80 & 7.8 & 11.7 & 19.5 & 11.5 & 21.6 & 33.2 & 5.2 & 3.9 & 9.1 \\
\hline 90 & 7.8 & 11.7 & 19.5 & 11.5 & 21.6 & 33.2 & 5.2 & 3.8 & 9.0 \\
\hline $100 \mathrm{~cm}$ & 7.8 & 11.7 & 19.5 & 11.5 & 21.6 & 33.2 & 5.2 & 3.8 & 9.0 \\
\hline
\end{tabular}

*Calculations are based on the assumption that development does not prevent new wetlands from forming inland. If adjacent lowlands are protected, rises of between 1 and $1.6 \mathrm{~m}$ would destroy the remaining marsh.

\section{Barrier Islands, Deltas, and Saltwater Intrusion}

Although most marshes could probably not keep pace with a substantial acceleration in sea level rise, three possible exceptions are the marshes found in river deltas, tidal inlets, and on the bay sides of barrier islands. River and tidal deltas receive much more sediment than wetlands elsewhere; hence they might be able to keep pace with a more rapid rise in sea level. For example, the sediment washing down the Mississippi river for a long time was more than enough to sustain the delta and enable it to advance into the Gulf of Mexico, even though relative sea level rise there is approximately one centimeter per year, due to subsidence (Gagliano, MeyerArendt, and Wicker 1981). A global sea level rise of one centimeter per year would double the rate of relative sea level rise there to two centimeters per year; thus, a given sediment supply could not sustain as great an area of wetlands as before. It could, however, enable a substantial fraction to keep pace with sea level rise.

In response to sea level rise, barrier islands tend to migrate landward as storms wash sand from the ocean side beach to the bay side marsh (Leatherman 1982). This "overwash" process may enable barrier islands to keep pace with an accelerated rise in sea level. However, it is also possible that accelerated sea level rise could cause these islands to disintegrate. In coastal Louisiana, where rapid subsidence has resulted in a relative sea level rise of one centimeter per year, barrier islands have broken up. The Ship Island of the early twentieth century is now known as "Ship Shoal" (Pendland, Suter, and Maslow 1986).

Marshes often form in the flood (inland) tidal deltas (shoals) that form in the inlets between barrier islands. Because these deltas are in equilibrium with sea level, a rise in sea level would tend to raise them as well, with sediment being supplied primarily from the adjacent islands. 
Moreover, if sea level rise causes barrier islands to breach, additional tidal deltas will form in the new inlets, creating more marsh, at least temporarily. In the long run, however, the breakup of barrier islands would result in a loss of marsh. Larger waves would strike the wetlands that form in tidal deltas and in estuaries behind barrier islands. Wave erosion of marshes could also be exacerbated if sea level rise deepens the estuaries. This deepening would allow ocean waves to retain more energy and larger waves to form in bays. Major landowners and the government of Terrebonne Parish, Louisiana, consider this possibility a serious threat and are taking action to prevent the breakup of Isle Derniere and others around Terrebonne Bay (Terrebonne Parish 1984).

Sea level rise could also disrupt coastal wetlands by a mechanism known as saltwater intrusion, particularly in Louisiana and Florida. In many areas the zonation of wetlands depends not so much on elevation as on proximity to the sea, which determines salinity. The most seaward wetlands are salt marshes or their tropical equivalent, mangrove swamps. As one moves inland, the fresh water flowing to the sea reduces salinity, and brackish wetlands are found. Still farther inland, the freshwater flow completely repels all salt water, and fresh marshes and cypress swamps are found.

Although these marshes may be tens (and in Louisiana, hundreds) of kilometers inland, their elevation is often the same as that of the saline wetlands. A rise in sea level enables salt water to penetrate upstream and inland, particularly during droughts. In many areas, the major impact would be to replace freshwater species with salt-tolerant marsh. However, many of the extensive cypress swamps in Louisiana, Florida, and South Carolina, as well as some "floating marshes," lack a suitable base for salt marshes to form. These swamps could convert to open water if invaded by salt, which is already occurring in Louisiana (Wicker et al. 1980).

\section{HUMAN INTERFERENCE WITH NATURE'S RESPONSE TO SEA LEVEL RISE}

Although the natural impact of the projected rise in sea level is likely to reduce wetland acreages, the ecosystems would not necessarily be completely destroyed. However, human activities such as development and river flow management could disable many of the natural mechanisms that allow wetlands to adapt to a rising sea, and thereby substantially increase the loss of wetlands over what would occur naturally. In some areas the impacts could be so severe that entire ecosystems could be lost.

\section{Development and Bulkheads}

Although environmental regulations have often prevented or discouraged people from building on wetlands, they have not prevented people from building just inland of the marsh. As the final box in Figure 1-5 shows, wetlands could be completely squeezed between an advancing sea and bulkheads erected to protect developed areas from the sea. A few jurisdictions, such as Massachusetts, currently prohibit additional construction of bulkheads that prevent inland advance of marshes ${ }^{9}$ However, these provisions were enacted before there was a concern about accelerated sea level rise; it is unclear whether they would be enforced if sea level rise accelerates. Moreover, bulkheads are already found along much of the shore and are generally exempt from such provisions.

The amount of sea level rise necessary for development to prevent new marsh from forming would depend on the extent to which development is set back from the wetlands. In Maryland, for example, the Chesapeake Bay Critical Areas Act forbids most new development within 1,000 feet of the marsh; thus, if the sea rises 50 centimeters (the highest part of the marsh) in excess of the vertical accretion, there may still be 1,000 feet of marsh. Additional rises in sea level, however, would eventually squeeze out the marsh. 
In the Charleston area, development is prohibited in the transition wetlands, which extend 75 centimeters ( 2.5 feet) above the high marsh. Thus, Kana, Baca, and Williams (Chapter 2) estimate that in the low scenario, protecting development will not increase the loss of marsh through 2075, although it would increase the loss of transition wetlands. For the high scenario, however, protecting development would result in a 100 percent loss of high marsh (compared with a 71 percent loss), and would increase the loss of low marsh slightly (from 84 to 86 percent) by 2075. As Figure 1-8 shows, a two-meter rise by 2100 could result in a 100 percent loss of all marsh if development is protected.

Kana et al. do not explore the implications of protecting development in the New Jersey study. About one half of the marsh in that study falls within Brigantine National Wildlife Refuge, and hence is off-limits to development. New development in the other part of the study area must be set back 50 to 300 feet from the marsh..$^{10}$ Although the buffer zone would offer some protection, eventually the marshes here would also be squeezed out.

The development of coastal areas may have one positive impact on the ability of marshes to adapt to a rising sea. The development of barrier islands virtually guarantees that substantial efforts will be undertaken to ensure that developed islands do not break up or become submerged as the sea rises. Thus, these coastal barriers will continue to protect wetlands from the larger ocean and gulf waves for at least the next several decades and, in some cases, much longer. ${ }^{11}$

This positive contribution may be offset to some extent by human interference with the natural overwash process of barrier islands. Under natural conditions, storms would supply marshes on the bay sides of barrier islands with additional sediment, to enable them to keep pace with sea level rise. On developed barrier islands, however, public officials generally push the overwashed sand back to the oceanside beach, which could inhibit the ability of these barrier marshes to keep pace with sea level rise. In many instances, however, these marshes have already been filled for building lots.

\section{Louisiana and Other River Deltas}

Although natural processes would permit a large fraction of most river deltas to keep pace with sea level, human activities may thwart these processes. Throughout the world, people have dammed, leveed, and channelized major rivers, curtailing the amount of sediment that reaches the deltas. Even at today's rate of sea level rise, substantial amounts of land are converting to open water in Egypt and Mexico (Milliman and Meade 1983).

In the United States, Louisiana is losing over 100 square kilometers (about 50 square miles) per year of wetlands (Boesch 1982). Until about one hundred years ago, the Mississippi Delta gradually expanded into the Gulf of Mexico. Although the deltaic sediments tend to settle and subside about one centimeter per year, the annual flooding permitted the river to overflow its banks, providing enough sediment to the wetlands to enable them to keep pace with relative sea level rise, as well as expand farther into the Gulf of Mexico.

In the middle of the 19th century, however, the Corps of Engineers learned of a new way to reduce dredging costs at the mouth of the Mississippi River. Two large jetties were built to confine the river flow, preventing the sediment from settling out and creating shoals and marsh in and around the shipping lanes. Instead, the sediment is carried out into the deep waters of the Gulf of Mexico. The "self-scouring" capability of the channels has been gradually increased over the years. The banks of the lower part of the river are maintained to prevent the formation of minor channels that might carry sediment and water to the marsh, and thereby slow the current. The system works so well that dredging operations in the lower part of the river often involve deliberately resuspending the dredged materials in the middle of the river and allowing it to wash into the Gulf of Mexico, rather than disposing of the dredged spoils nearby. Although the channelization of the river has enabled costeffective improvements in navigation, it prevents sediment, fresh water, and nutrients from reaching the wetlands near the mouth of the river. 
Since the 1930s, levees have been built along both sides of the river to prevent the river from overflowing its banks during spring flooding, and several minor "distributaries" (alternative channels that lead through the wetlands to the Gulf of Mexico) have been sealed off. Although these actions have reduced the risk of river flooding in Louisiana, they also prevent sediment and fresh water from reaching the wetlands. As a result, wetlands are gradually submerged, and salt water is intruding farther inland, killing some cypress swamps and converting freshwater marsh to brackish and saline marsh. Finally, dams and locks on the upper Mississippi, Arkansas, Missouri, and Ohio Rivers (and improved soil conservation practices) have cut in half the amount of sediment flowing down the river, limiting the growth of wetlands in the Atchafalaya delta, the one area that has not (yet) been completely leveed and channelized.

Canals and poor land use practices have also resulted in wetland loss (Turner, Costanza, and Scaife 1982). However, levees and channels are particularly important because they disable the mechanisms that could enable the wetlands to repair themselves and keep pace with sea level. With almost no sediment reaching the wetlands, an accelerated rise in sea level could destroy most of Louisiana's wetlands in the next century.

Figure 1-9 illustrates the disintegration of wetlands at the mouth of the main channel of the Mississippi River between 1956 and 1978. Because there are no levees this far downstream, this marsh loss is attributable to navigation projects. Figure 1-10 illustrates changes in Terrebonne Parish's wetlands from 1955 to 1978 . Note the extensive conversion of fresh marsh to saline and brackish marsh, as well as the conversion of cypress swamps to open water. Figure 1-11 shows the generally expected shoreline for Louisiana in the year 2030 if current management practices and sea level trends continue. Although projects to slow the rate of wetland loss may improve this picture, accelerated sea level rise could worsen it. Figure 1-12 shows the loss expected if sea level rises $55 \mathrm{~cm}$ by 2050 . 


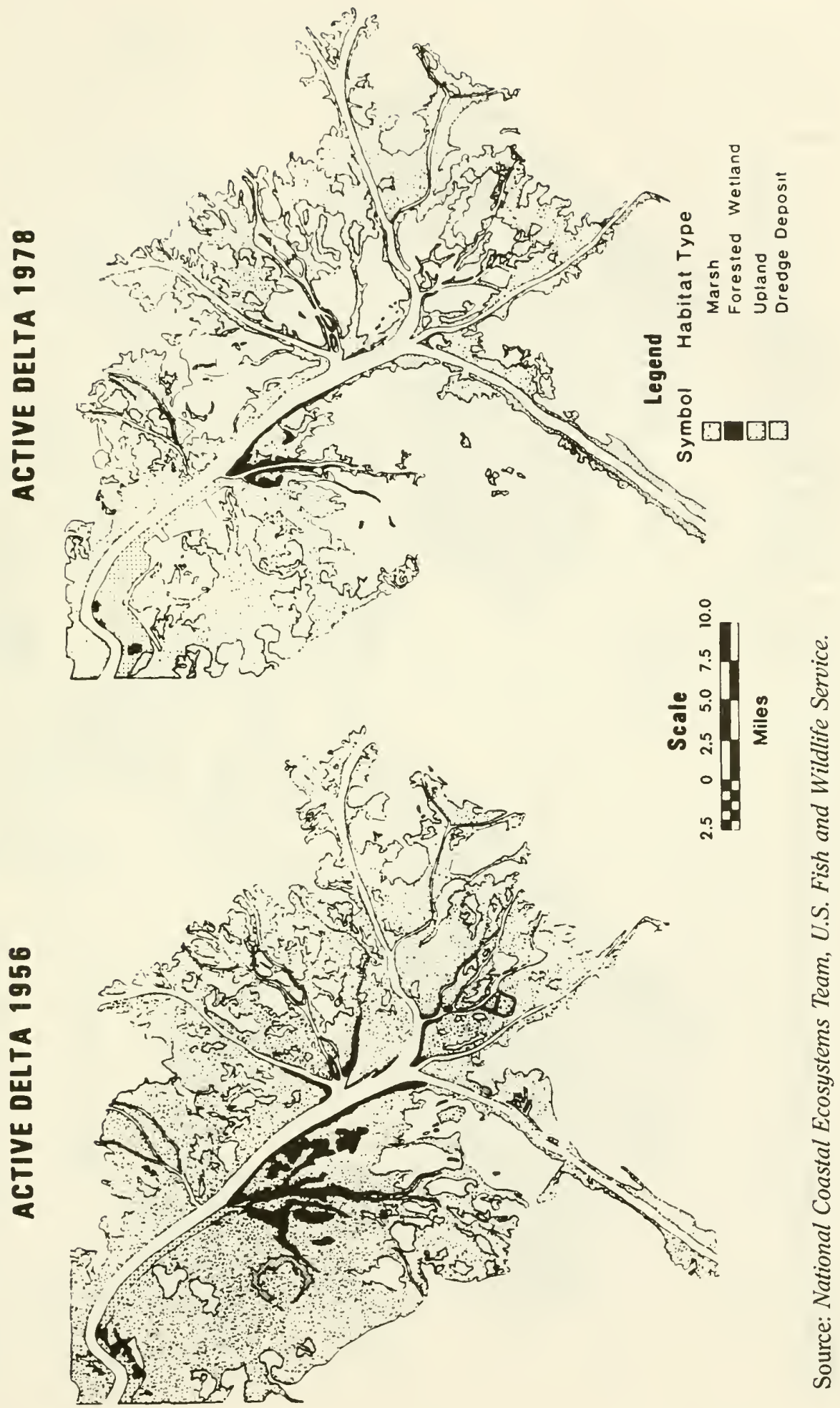



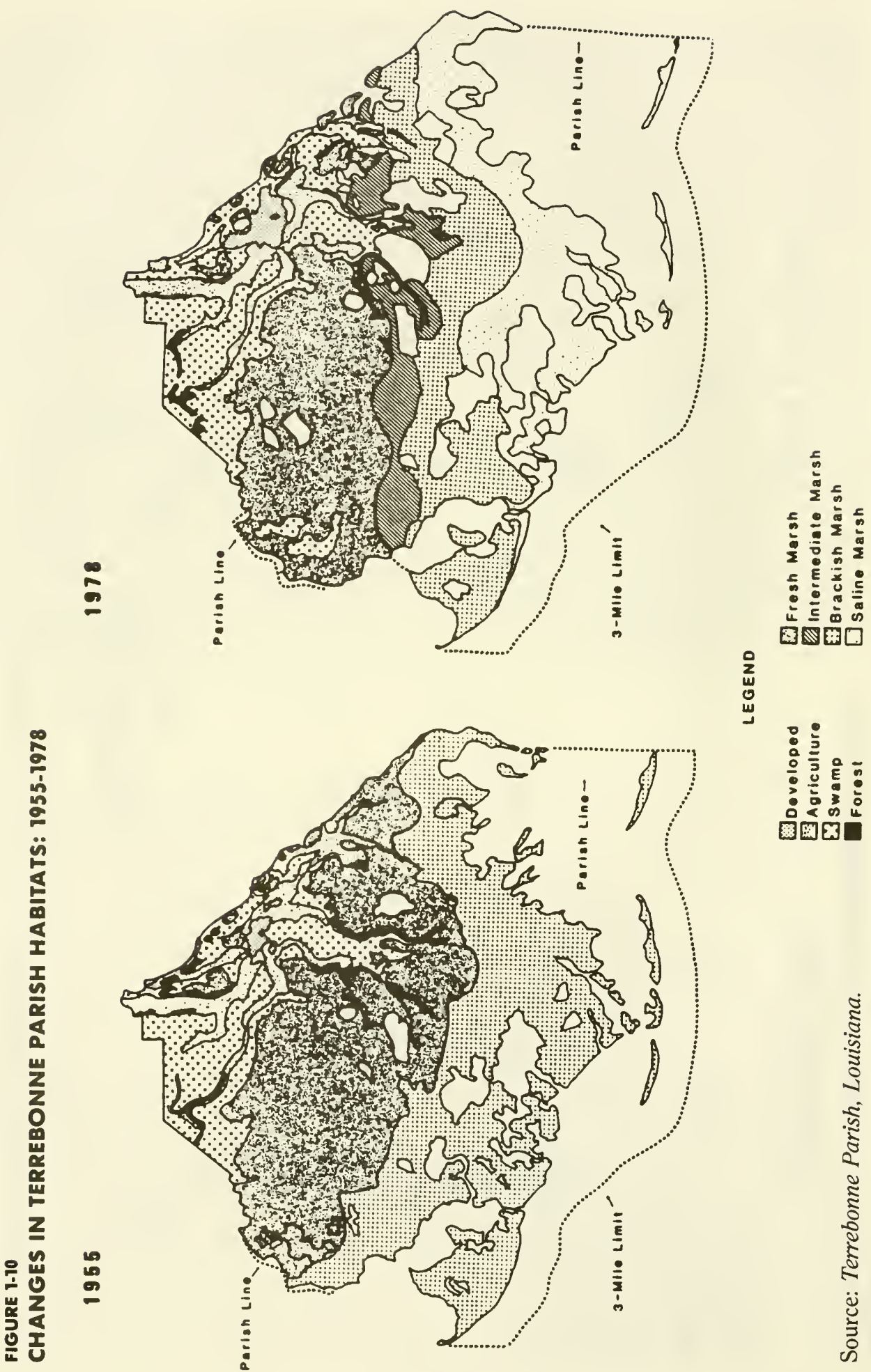


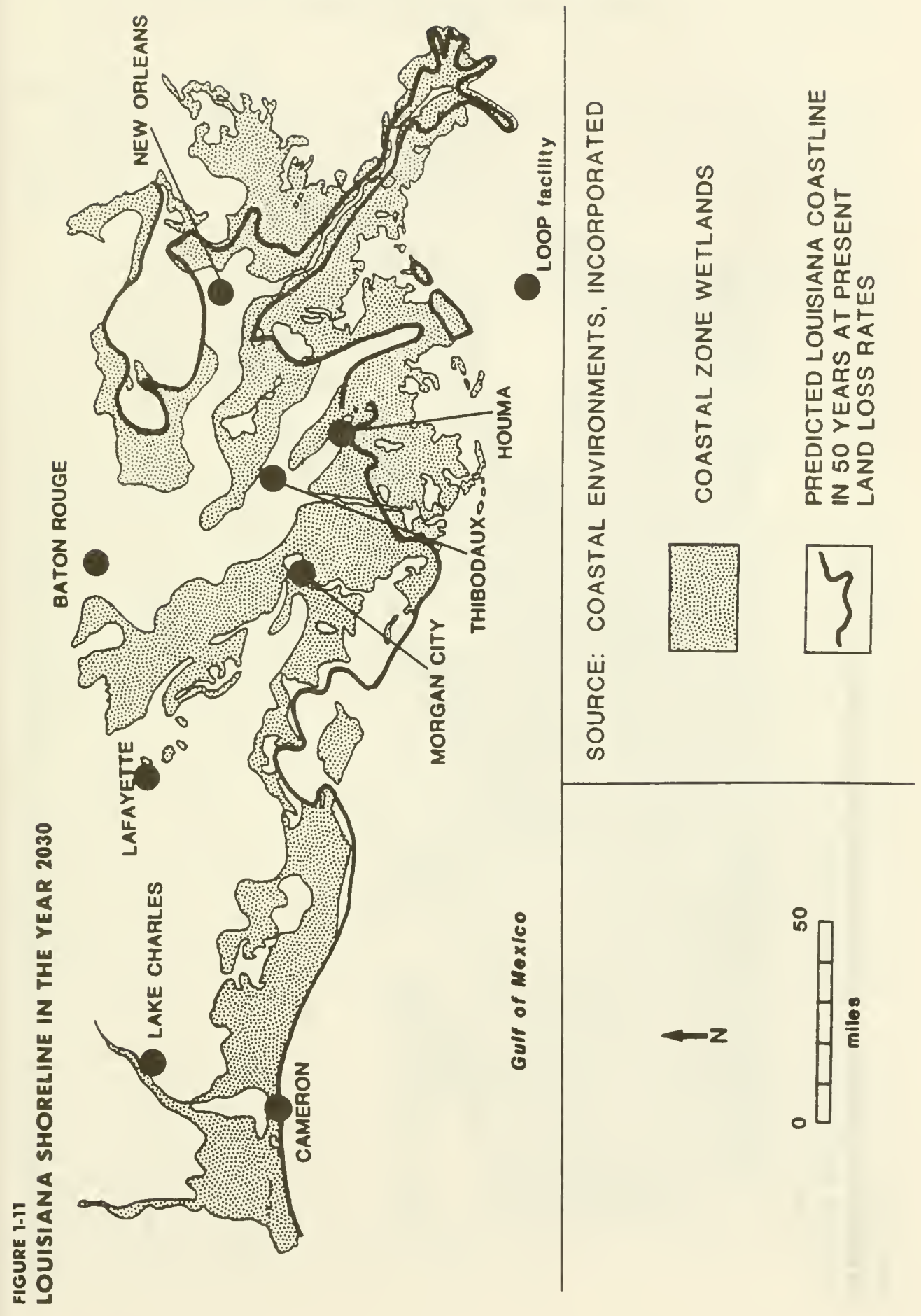




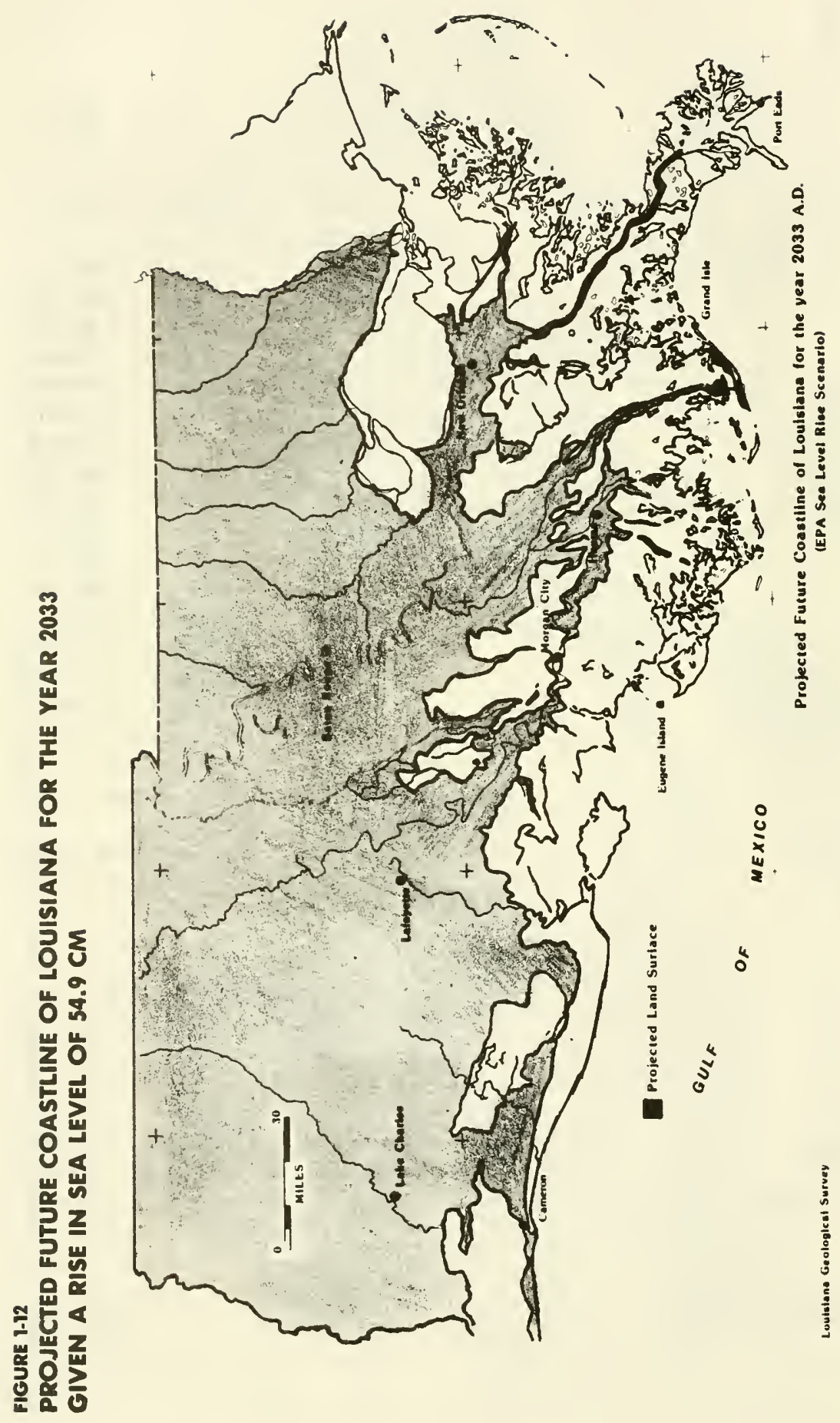

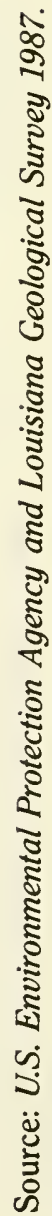




\section{NATIONWIDE LOSS OF WETLANDS: \\ A FIRST APPROXIMATION}

\section{Methods}

The case studies of South Carolina and New Jersey illustrate the hypothesis that a rapid rise in sea level would drown more wetlands than it would create. Nevertheless, to demonstrate the general applicability of this hypothesis requires more than two case studies. Although this project did not have thie resources necessary to conduct additional field surveys, we wanted to develop at least a rough estimate of the likely nationwide loss of coastal wetlands.

Armentano et al. (Chapter 4) use topographical maps, information on tidal ranges, and a computer model to estimate the impacts of sea level rise on 57 sites comprising 4800 square kilometers (1,200,000 acres) of wetlands, over 17 percent of all U.S. coastal wetlands. For each square kilometer they assigned a single elevation. If the map has ten-foot contours, and most of a square is between five and fifteen feet above sea level, they assigned the entire square an elevation of ten feet. If the map shows that a particular area is marsh, they gave it the marsh designation and an elevation based on a linear interpolation between the shoreline and the first contour, generally at elevation 10 feet. Their data base also considered whether a particular area is developed or undeveloped, and whether there is an existing flood-protection wall or bulkhead.

Although their data base was much more coarse, Armentano et al. use a more sophisticated model for projecting the impact of sea level rise than Kana et al. The latter simply subtracted estimated vertical accretion from relative sea level rise for the year 2075, to yield an estimate of net substrate change for the entire period. Armentano et al. also subtract vertical accretion from relative sea level rise, but in five-year increments. Once an area is below spring high tide, it is assumed to be marsh; once it is below mean low water, it converts from marsh to open water. This procedure makes it possible to display results of wetland loss for particular years, and to consider changes in marsh accretion rates during the forecast period. Armentano et al. also account for changes in exposure to waves due to destruction of barrier islands and spits.

Because elevations are estimated crudely, one should be suspicious of individual results. Although marsh is generally found at elevations ranging from mean sea level to spring tide, Armentano et al. assign it all to a single elevation for a particular cell based on contours that generally describe elevation of adjacent dry land, not the elevation of the marsh, rounded to the nearest half meter. If the change in water depth (relative sea level rise minus accretion) is small, the model assumes no loss of marsh; whereas some marsh would actually be lost. Conversely, for a water depth greater than the estimated elevation above mean low water, all the marsh is assumed lost; whereas the marsh between that elevation and spring high tide would actually remain marsh. Similarly, the model may tend to underestimate marsh creation for small rises in sea level while overestimating creation for larger rises.

The estimates by Armentano et al. were based on a number of conservative assumptions that may tend to understate wetland loss. They assumed that the New England, Florida, and Texas marshes are not subsiding, whereas tide gauges indicate that these areas are subsiding between one and two millimeters per year (Hicks et al. 1983). Moreover, they assumed that sea level rise would not convert marsh until mean low water had risen above the marsh; by contrast, marsh is often not found below mean sea level, and in the case of Charleston, Kana et al. found that it is generally at least 30 centimeters above today's mean sea level (NGVD elevation 45 centimeters). Finally, the linearity assumption tends to understate marsh loss in areas where the profile is concave, as in Figures 1-5 and 1-6 and most coastal areas. 


\section{Regional Results}

Armentano et al. emphasize that their estimates should not be considered as statistically valid estimates of wetland loss in particular U.S. coastal regions. Nevertheless, we believe that the results provide a useful and indicative first approximation.

Table 1-5 summarizes their estimates for the low and high sea level rise scenarios. The first two columns of the bottom half show their estimates of the wetland loss that would take place if development prevented new marsh from forming inland. The other two columns show their estimates of the net change in wetland acreage assuming that development does not prevent new marsh from forming except where the shoreline already has bulkheads, levees, or other shore protection structures. These assumptions are both extreme. Complete protection of all existing dry land would be very unlikely, as would a total abandonment of all (currently) unprotected areas just inland of the wetlands. The extent to which development retreats would depend both on economics and on public policies regarding the appropriate level of wetland protection in the face of rising sea level. An investigation of these issues, however, was outside the scope of that study.

\section{TABLE 7.5}

\section{SAMPLE CHANGES IN COASTAL WETLANDS: $1975-2100$}

REGION

Wetland Area (square kilometers)
New England

Mid At lantic

South Atlantic

Florida

N.E. Gulf Coast

Mississippi Delta*

Chenier Plain, Tex

Californian Prov.

Columbian Prov.

TOTAL

Percent Loss (gain)

New England

Mid At lantic

South Atlantic

Florida

N.E. Gulf Coast

Mississippi Delta*

Chenier Plain, Tex

Californian Prov.

Columbian Prov. $\underline{1980}$

\begin{tabular}{lll}
\hline Defend Shore & Abandonment \\
Low & $\underline{\text { High }}$ & Low $\quad$ High
\end{tabular}

TOTAL

60
454
913
598
736
1509
299
265
12

4846

$\begin{array}{rrr}22 & 58 & 22 \\ 0 & 366 & 66 \\ 208 & 954 & 420 \\ 357 & 770 & 517 \\ 520 & 685 & 544 \\ 45 & 298 & 45 \\ 0 & 258 & 49 \\ 0 & 263 & 218 \\ 9 & 127 & 133 \\ & & \\ 1161 & 3779 & 2014\end{array}$

22

66

420

517

544

45

49

133

2014

"These estimates do not consider the potential wetland creation that could result from possible diversion of the Mississippi River. 
Armentano et al. estimate that the low scenario would have relatively little impact on New England's marshes, largely due to their ability to keep pace through peat formation. Nevertheless, peat formation would not be likely to keep pace with the more rapid rate of sea level rise implied by the high scenario, which could result in two-thirds of these marshes being lost. Similar situations could be expected in Florida and the Northeast Gulf Coast, although a flatter coastal plain in these regions would offer a greater potential for wetland creation if development did not stand in the way. The assumption by Armentano et al. that Florida wetlands could accrete one centimeter per year may be unduly optimistic.

The middle and southern Atlantic coastal marshes would be more vulnerable than New England to the low sea level rise scenario, largely because smaller tidal ranges there imply that existing wetlands are found at lower elevations than the New England wetlands, while vertical accretion was generally assumed to be less than in the case of Florida and the Northeast Gulf Coast. These estimates appear to imply less wetland loss than the case studies by Kana et al. In the high scenario, however, estimates by Armentano et al. are considerably higher and more closely consistent with Kana et al., as we discuss below.

To understand the implications of Armentano et al., it is useful to compare their procedures and results with those of Kana et al., where there is site-specific information. In the case of Charleston, Armentano et al. estimate that the low scenario (net substrate change, 111 centimeters) implies a 37 percent loss and a 21 percent gain through 2100 , for a net loss of 16 percent. The transects of Kana et al. imply that the low scenario would result in a 100 percent loss of existing marsh with an 18 percent gain, for a net loss of 82 percent. Had the Armentano et al. approach been applied to the Charleston case study, it would have attributed an initial elevation of 1.0 meters to the marsh, ${ }^{12}$ which is not unreasonable given that it ranges from 0.5 to 1.3 meters-although 80 percent of the marsh is below 1.0 meters. However, their procedure would require the net substrate change to be one meter plus one-half the tidal range, for a total rise of 1.8 meters, before the marsh would convert to water. Thus, the model of Armentano et al. estimates Charleston's wetlands to be much less vulnerable than the field surveys by Kana et al. suggest. ${ }^{13}$

In the case of the New Jersey wetlands, the groups arrived at similar results. Armentano et al. estimate a 75 percent wetland loss through 2075 in the high scenario and no loss in the low scenario, while Kana et al. estimate an 86 percent loss in the high scenario and a 6 percent gain in the low. The tendency of Armentano et al. to assign a fairly high elevation to the marsh is more appropriate in areas where high marsh dominates. Moreover, five-foot contours were available in this case. Table 1-6 summarizes the Armentano et al. and Kana et al. findings.

\section{TABLE 1-6}

\section{COMPARISON OF ARMENTANO ET AL. AND KANA ET AL. STUDY RESULTS SHOWS THAT USE OF TOPOGRAPHIC MAPS CAN UNDERESTIMATE VULNERABILITY OF WETLANDS TO SEA LEVEL RISE (percent loss of wetlands)}

\begin{tabular}{|c|c|c|c|c|}
\hline & \multicolumn{2}{|c|}{ Low Scenario } & \multicolumn{2}{|c|}{ High Scenario } \\
\hline & Abandonment & $\begin{array}{l}\text { Defend } \\
\text { Shore }\end{array}$ & Abandonment & $\begin{array}{l}\text { Defend } \\
\text { Shore }\end{array}$ \\
\hline Charleston, South Carolina (2100) & & & & \\
\hline Armentano et al. & 16 & 37 & 28 & 55 \\
\hline Kana et al.' & 82 & 100 & 84 & 100 \\
\hline $\begin{array}{l}\text { Tuckerton, New Jersey (2075) } \\
\text { Armentano et al. } \\
\text { Kana et al. }\end{array}$ & $\begin{array}{l}0 \\
4\end{array}$ & - & $\begin{array}{l}75 \\
82\end{array}$ & \\
\hline
\end{tabular}

${ }^{1}$ These results are derived from the profile estimated by Kana et al. 
The Mississippi Delta and Texas Chenier Plain wetlands appear to be the most vulnerable. As Table 1-5 shows, 36 percent of the latter would be lost in the low scenario, and all could be lost in the high scenario. Abandonment would increase the portion of wetlands surviving the next century by about 15 percent of today's acreage. Armentano et al. estimate that 80 and 97 percent of Louisiana's wetlands would be lost for the low and high scenarios, respectively. However, we caution the reader that their model did not consider the potential positive impacts of a diversion of the Mississippi River, which could enable a fraction of the wetlands to survive a more rapidly rising sea level.

Although the Pacific Coast wetlands examined appear to be as vulnerable to sea level rise as Atlantic and Gulf coast wetlands, Armentano et al. found that the former have greater potential for wetland creation with sea level rise. In the Californian study areas, 35 to 100 percent of the existing wetlands could be lost; however, the net loss would be 1 to 18 percent if developed areas were abandoned.

The Pacific Northwest study site could experience a tenfold increase in wetland area for either scenario, if uplands are abandoned. However, we suggest that the reader not attribute undue significance to the Columbia River results. This study site accounted for less than 5 percent of the Pacific Coast marshes considered. The result is a useful reminder of the fact that some areas could gain substantial amounts of wetland acreage. We do not recommend, however, that any of the regional results be taken too seriously until they can be verified by additional study sites and a more detailed examination of wetland and upland transects, such as those in Chapters 2 and 3.

\section{Nationwide Estimate}

The results of Armentano et al. can be used to derive a rough estimate of the potential nationwide loss of coastal wetlands. However, the reader should note that Armentano et al. did not use a completely random method for picking study areas, and that their elevation estimates were rounded to the nearest quarter meter. Thus, they warn the reader that estimates based on their projections are not statistically valid.

Armentano et al. sought to include study sites for all major sections of coast. However, they did not attempt to ensure that the wetland acreage of the sites in a particular region are directly proportional to the total acreage of wetlands in that region. Therefore, to derive a nationwide estimate of the loss of wetlands one should weight estimates of "percentage loss by region" by actual wetland acreages in the various regions.

A recent study by the National Ocean Service estimates coastal wetland acreage by state (Alexander, Broutman, and Field 1986). We modified those estimates to exclude swamp acreage in regions where Armentano et al. did not investigate swamps. The term "coastal wetland" in this report refers to tidal wetlands and non-tidal wetlands that are hydraulically connected to the sea, such as cypress swamps in Louisiana. The NOS study includes all swamps in coastal counties, some of which are well inland and not hydraulically connected to the sea, particularly in North Carolina and New Jersey.

The first column of Table 1-7 shows the adjusted estimates of wetlands acreage by region. Because the Pacific Coast wetlands represent such a small fraction of the total, we have combined the California and Pacific Northwest regions. The rest of the table shows the implied wetland losses and gains estimated using the percentages reported by Armentano et al. The greatest losses would appear to be in Louisiana and the southern and middle Atlantic coast. However, we caution the reader that the region-specific estimates have less credibility than the nationwide estimate.

Of the estimated 6.9 million acres of coastal wetlands, 3.3 million could be lost under the low scenario. If human activities do not interfere, however, 1.1 million acres might be created. Under the high scenario, 5.7 million acres ( 81 percent) would be lost, while 1.9 million acres could potentially be created. 
These estimates of the nationwide loss of wetlands are based on dozens of assumptions. Nevertheless, they seem to support the simple hypothesis that the area of wetlands today is greater than what would be at the proper elevation for supporting wetlands if sea level rose a meter or two. Thus, if rates of vertical accretion remain constant, a rise of this magnitude in the next century would destroy most U.S. coastal wetlands.

TABLE 1-7

PROJECTED U.S. COASTAL WETLAND LOSS AND POTENTIAL GAIN (thousands of acres)

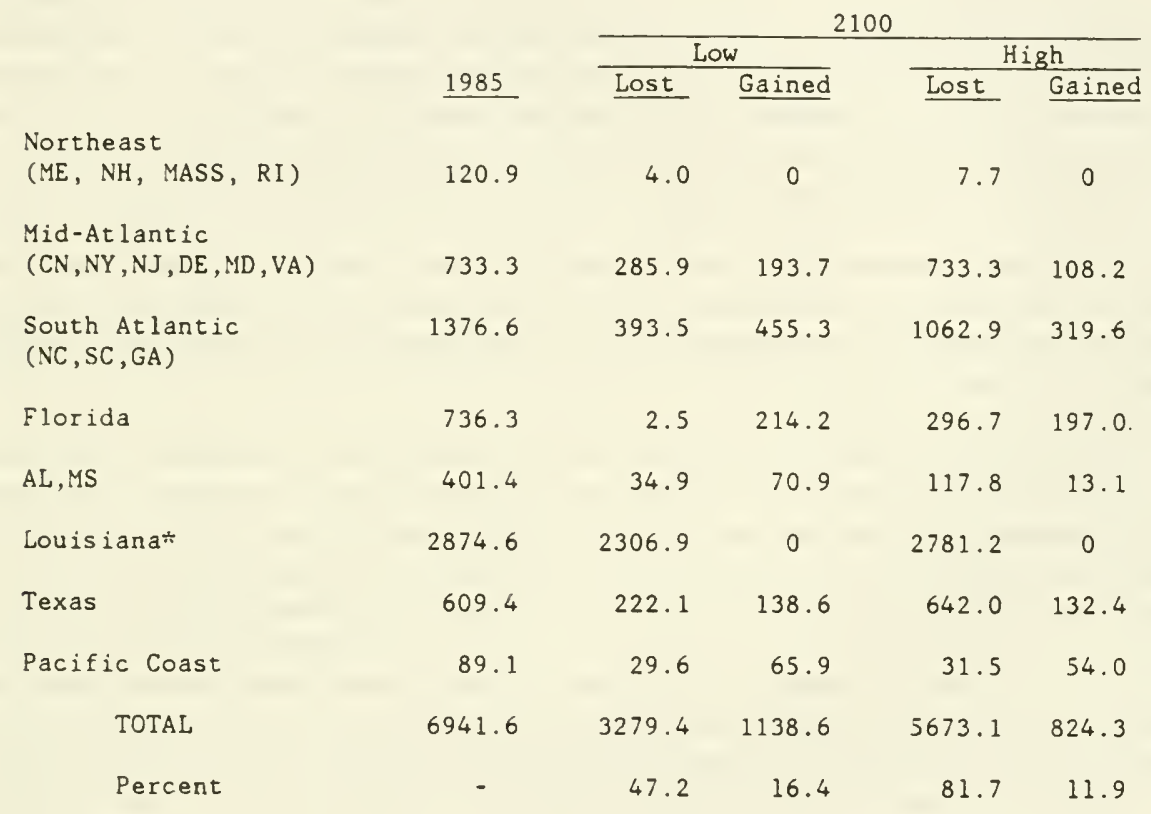

-These estimates do not consider the potential wetland creation that could result from possible diversions of the Mississippi River planned and authorized by the State of Louisiana.

Source: 1985 inventory from Alexander, Broutman, and Field 1986. Nationwide losses calculated by applying percentages from Table 1.5 to 1985 inventory "Lost" refers to wetlands inundated. "Gained" refers to potential increases in wetland acreage if upland areas are not developed or if development is removed.

\section{PREVENTING FUTURE WETLAND LOSSES}

Future losses of wetlands from sea level rise could be reduced by (1) slowing the rate of sea level rise, (2) enhancing wetlands' ability to keep pace with sea level rise, (3) decreasing human interference with the natural processes by which wetlands adapt to sea level rise, or (4) holding back the sea while maintaining the marshes artificially. ${ }^{14}$

Society could curtail the projected future acceleration of sea level rise by limiting the projected increases in concentrations of greenhouse gases. Seidel and Keyes (1983) projected 
that reducing $\mathrm{CO}_{2}$ emissions with bans on coal, shale oil, and synfuels (but not oil and gas) would delay a projected two degree (C) warming from 2040 to 2065; because of the thermal delay of the oceans, the resulting thermal expansion of ocean water would be delayed ten to fifteen years. ${ }^{15}$ Other trace gases might also be controlled. Hoffman et al. (1986) showed that the acceleration of sea level rise could be significantly delayed through controls of greenhouse gas emissions.

Although limiting the rise in sea level from the greenhouse effect might be the preferred solution for most parties involved in the wetland protection process, it would also be largely outside of their control. The nations of the world would have to agree to replace many industrial activities with processes that do not release greenhouse gases, perhaps at great cost. A decision to limit the warming would have to weigh these costs against many other possible impacts of the greenhouse warming which are understood far less than wetland loss from a rise in sea level, including the economic impacts of sea level rise; environmental consequences for interior areas, such as an increase in desertification; and possible disruptions of the world's food supply. Perhaps the most important challenge related to this option is that it would have to be implemented at least fifty years before the consequences it attempts to avert would have taken place.

Because we may have passed the time when it would be feasible to completely prevent an accelerated rise in sea level, wetland protection officials may also want to consider measures that would enable wetlands to adapt to rising sea level. Enhancing the ability of wetlands to keep pace with sea level rise has the advantage that such measures, which include marsh building, enhanced sedimentation, and enhanced peat formation, would not have to be implemented until sea level rise has accelerated.

Current environmental policies often require marsh building to mitigate destruction of wetlands. Although this measure will continue to be appropriate in many instances, it can cost tens of thousands of dollars per acre, which would imply tens of billions of dollars through 2100 if applied universally. Enhanced sedimentation may be more costeffective; it is generally cheaper to save an acre of marsh than to create an acre of new marsh. Technologies that promote vertical growth of marshes generally spray sediment in a manner that imitates natural flooding (Deal 1984). Although these technologies look promising, they are barely past the development stage and may also prove too costly to apply everywhere. Although processes for enhancing peat formation might prove feasible, reduced peat formation might also result from climate change.

Allowing wetlands to adapt naturally to sea level rise would not prevent a large reduction in acreage, but might allow the ecosystems themselves to survive. This option would consist primarily of removing human impediments to sedimentation and the landward migration of wetlands. The sediment washing down the Mississippi River, for example, would be sufficient to sustain a large part of Louisiana's wetlands, if human activities do not continue to force sediment into the deep waters of the Gulf of Mexico. However, the costs of restoring the delta would be immediate, while the benefits would accrue over many decades. Similarly, measures could be taken to ensure that the wetlands in tidal deltas adjacent to barrier island inlets are not deprived of sediment by groins and jetties built to keep sand on the islands and out of the inlet.

For the extensive mainland marshes not part of a tidal delta, a natural adaptation would require the wetlands to migrate landward and up the coastal plain. Such a policy would also be costly. It would be necessary to either prevent development of areas just upland of existing wetlands, or to remove structures at a later date if and when the sea rises. Preventing the development of the upland areas would require either purchasing all the undeveloped land adjacent to coastal marshes or instituting regulations that curtailed the right to build on this property. The former option would be costly to taxpayers, while the latter option would be costly to property owners and would face legal challenges that might result in requirements for compensation.

Developing upland areas and later removing structures as the sea rises would allow costs to be deferred until better information about sea level rise could be obtained. This option could be 
implemented either through an unplanned retreat or a planned retreat. Howard, Pilkey, and Kaufman (1985) discuss several measures for implementing a planned retreat along the open coast. Although North Carolina and other coastal areas have required houses to be moved inland in response to erosion along the open coast-where shore protection is expensive-it may be more difficult to convince people that the need for wetland protection also justifies removal of structures.

There is also a class of institutional measures that increases the flexibility of future generations to implement a retreat if it becomes necessary, without imposing high costs today. For example, permits for new construction can specify that the property reverts to nature one hundred years hence if sea level rises so many feet. Such a requirement can ensure the continued survival of coastal wetlands, yet is less likely to be opposed by developers than policies that prohibit construction. Moreover, with the government's response to sea level rise decided, real estate markets can incorporate new information on sea level rise into property values. The State of Maine (1987) has adopted this approach, specifying that houses are presumed to be moveable. In the case of hotels and condominiums, the owner must demonstrate that the building would not interfere with natural shorelines in the event of a rise in sea level of up to three feet, or that he or she has a plan for removing the structure if and when such a rise occurs.

Finally, it might be possible to hold back the sea and maintain wetlands artificially. For small amounts of sea level rise, tidal gates might be installed that open during low tide but close during high tide, thereby preventing saltwater intrusion and lowering average water levels. For a larger rise, levees and pumping systems could be installed to keep wetland water levels below sea level. Although these measures would be expensive, they would also help to protect developed areas from the sea. Terrebonne Parish, Louisiana, is actively considering a tidal protection system and a levee and pumping system to prevent the entire jurisdiction from converting to open water in the next century (Edmonson and Jones 1985). They note, however, that effective measures to enable shrimp and other seafood species to migrate between the protected marshes and the sea have not yet been demonstrated.

Measures to ensure the continued survival of wetland ecosystems as sea level rises need to be thoroughly assessed. We may be overlooking opportunities where the cost of implementing solutions in the near term would be a small fraction of the costs that would be required later. Only if these measures are identified and investigated will it be possible to formulate strategies in a timely manner.

\section{CONCLUSIONS}

An increasing body of evidence indicates that increasing concentrations of greenhouse gases could cause sea level to rise one or two meters by the year 2100. If current development and river management practices continue, such a rise would destroy the majority of U.S. coastal wetlands. Yet these losses could be substantially reduced by timely anticipatory measures, including land use planning, river diversion, and research on artificially enhancing coastal wetlands, as well as by a reduction in emissions of greenhouse gases.

Case studies of South Carolina and New Jersey marshes indicate that a two-meter rise would destroy 80 to 90 percent of the coastal marshes, depending on development practices, while a one-meter rise would destroy 50 percent or less. The large body of research previously conducted in Louisiana suggests that its marshes and swamps would be far more vulnerable. Yet anticipatory measures, if implemented soon, could save a large fraction of these wetlands.

For the rest of the nation, no site-specific research has been undertaken. Most of these wetlands are also within one or two meters of sea level. Preliminary analysis by Armentano et al. 
suggests that coastal wetlands throughout the nation would be vulnerable to such a rise, with the possible exception of areas with large tidal ranges or substantial terraces two or three meters above sea level.

Basic and applied research on the ability of wetlands to adjust to rising sea level would be valuable. Because sea level rose one meter per century on average from 15,000 B.C. until 5,000 B.C., it may be possible to better assess the response of wetlands to such a rise in the future. Research on how to artificially promote vertical accretion or control water levels is also important. Such research could benefit coastal states throughout the nation in the long run, although the short-run benefits of protecting Louisiana's wetlands- -40 percent of the total-suggests that such research should be initiated soon.

When is the appropriate time to respond to the potential loss of wetlands to a rising sea? If technical solutions are possible, it might be sufficient to wait until sea level rise accelerates. Where planning measures are appropriate, a thirty- to fifty-year lead time might be sufficient. Where policies are implemented that will determine the subsequent vulnerability of wetlands to sea level rise, it would be appropriate to consider sea level rise when those decisions are made. If society intends to avert a large rise in sea level, a lead time of fifty to one hundred years may be necessary.

Wetland protection policies and related institutions such as land ownership are currently based on the assumption that sea level is stable. Should they be modified to consider sea level rise today, after the rise is statistically confirmed, or not at all? This question will not only require technical assessments, but policy decisions regarding the value of protecting wetlands, our willingness to modify activities that destroy them, and the importance of preparing for a future that few of us will live to see.

\section{NOTES}

${ }^{1}$ Several reviewers suggested that these figures may overstate the decline in wetland loss because they exclude conversion for agriculture and other nonregulated wetland destruction.

${ }^{2}$ U.S. Fish and Wildlife Service, Charleston, South Carolina Office, personal communication, March 1986.

${ }^{3}$ This curve shows the concentration for Mauna Loa, Hawaii, which is sufficiently remote to represent the average northern hemispheric concentration. Measurements at the South Pole suggest that the concentration for the southern hemisphere lags at most a couple of years, since most of the sources are in the northern hemisphere.

${ }^{4}$ Studies on the greenhouse effect generally discuss the impacts of a carbon dioxide doubling. By "effective doubling of all greenhouse gases" we refer to any combination of increases in the concentration of the various gases that causes a warming equal to the warming caused by a doubling of carbon dioxide alone over 1900 levels. If the other gases contribute as much warming as carbon dioxide, the effective doubling would occur when carbon dioxide concentrations have reached $450 \mathrm{ppm}, 1.5$ times the year-1900 level.

${ }^{5}$ These estimates did not consider meltwater from Antarctica or ice discharge from Greenland.

${ }^{6}$ Low marsh is found below mean high tide, which is defined as one-half the tidal range above sea level; high marsh extends up to the spring high tide, generally less than three-quarters of a tidal range above sea level; and transition wetlands are somewhat higher.

${ }^{7}$ Personal communication. U.S. Fish and Wildlife Service, Charleston Office. The estimates exclude.forested wetlands and freshwater marshes, which are cleared for agriculture and silviculture. 
${ }^{8} \mathrm{~A}$ few reviewers noted that this hypothesis remains to be demonstrated. If insufficent flooding limits vertical accretion, a more rapid sea level rise would accelerate wetland accretion. However, there is little doubt that wetlands in Louisiana cannot keep pace with a rise of 1 $\mathrm{cm} /$ year in the absence of substantial sediment nourishment.

${ }^{9}$ For Massachusetts, see M.G.L. Ch. 13, S. 40 Reg. 310 C.M.R. 9.10 (2) of Massachusetts General Laws.

${ }^{10}$ As specified by the New Jersey Administrative Code, Wetland Buffer Policy, 7:7E-3.26.

${ }^{11} \mathrm{~A}$ few reviewers pointed out that coastal protection structures such as snowfences and seawalls can increase the probability of an eventual breakup. However, the longer-term strategy of raising the beach profile and island with fill does not share that liability.

12 The marsh would range from 0 to 2,500 feet from shore, while the ten-foot contour would be 3,500 feet from shore; the midpoint of the marsh would be about 1,200 feet from shore. A linear interpolation implies that this point has a one-meter elevation.

13 The Armentano et al. model has additional complexities, but the factors described here are most important in explaining the discrepancy with the Kana et al. results.

14 This report does not address the issue of whether wetlands should be maintained. It is possible that in some cases open water areas replacing wetlands would support sea grasses that provide ecological benefits as great as the benefits of the metlands they replace.

${ }^{15}$ Computer printout of results from Seidel and Keyes 1983.

\section{REFERENCES}

Alexander, C.E., M.A. Broutman, and D.W. Field, 1986. An Inventory of Coastal Wetlands of the USA. Rockville, MD: National Oceanic and Atmospheric Administration (NOAA), National Ocean Service.

Barnett, T.P., 1983. "Global Sea Level: Estimating and Explaining Apparent Changes.” In Coastal Zone 83, edited by O.T. Magoon, 2777-2795. New York: American Society of Civil Engineers.

Bentley, L., 1983. "The West Antarctic Ice Sheet: Diagnosis and Prognosis." In Proceedings: Carbon Dioxide Research Conference: Carbon Dioxide, Science, and Consensus, DOE Conference 820970. Washington, D.C.: Department of Energy.

Bindschadler, R., 1985. "Contribution of the Greenland Ice Cap to Changing Sea Level." In M.F. Meier, 1985. Glaciers Ice Sheets and Sea Level. Washington, D.C.: National Academy Press.

Boesch, D.F., (ed). 1982. Proceedings of the Conference of Coastal Erosion and Wetland Modification in Louisiana: Causes, Consequences, and Options, FWS-OBS-82/59. Washington, D.C.: Fish and Wildlife Service, Biological Services Program.

Charney, J., Chairman, Climate Research Board, 1979. Carbon Dioxide and Climate: A Scientific Assessment. Washington, D.C.: NAS Press.

Cowardin, L.W., V. Carter, F.C Golet, and E.T. LaRoe, 1979. Classification of Wetlands and Deepwater Habitats of the United States. Washington, D.C.: U.S. Fish and Wildlife Service.

Coleman, J. and Smith, 1964. Geological Society of America, Bulletin 75:833.

Deal, T., 1984. "Jet-Spray Water-Needed, and Water-Vac" (unpublished). Presented to Wetlands Conference of the Louisiana Intracoastal Seaway Association. Lafayette, Louisiana. Orlando: Aztec Development Company.

Donn, W.L., W.R. Farrand, and M. Ewing, 1962. "Pleistocene Ice Volumes and Sea-Level Lowering." Joumal of Ecology 70:206-214.

Edmonson, J. and R. Jones, 1985. Marsh Management in Terrebonne Parish. Terrebonne Parish Council: Houman, LA. 
Galaty, F.W., W.J. Allaway, and R.C. Kyle, 1985. Modern Real Estate Practice. Chicago: Real Estate Education Company.

Gagliano, S.M., K.J. Meyer-Arendt, and K.M. Wicker, 1981. "Land Loss in the Mississippi Deltaic Plain." In Trans. 31st Ann. Mtg., Gulf Coast Assoc. Geol. Soc. (GCAGS), Corpus Christi, Texas, pp. 293-300.

Gornitz, V., S. Lebedeff, and J. Hansen, 1982. "Global Sea Level Trends in the Past Century." Science 215:1611-1614.

Hansen, J.E., A. Lacis, D. Rind, and G. Russell, 1984. "Climate Sensitivity to Increasing Greenhouse Gases." In Greenhouse Effect and Sea Level Rise: A Challenge for This Generation, edited by M.C. Barth and J.G. Titus. New York: Van Nostrand Reinhold, p. 62.

Hardisky, M.A., and V. Klemas, 1983. "Tidal Wetlands Natural and Human-made Changes from 1973 to 1979 in Delaware: Mapping and Results." Envir Manage 7(4): 1-6.

Hays, J.P., and W.C. Pitman III, 1973. "Lithospheric Plate Motion, Sea Level Changes, and Climatic and Ecological Consequences." Nature 246:18-22.

Hicks, S.D., H.A. DeBaugh, and L.E. Hickman, 1983. Sea Level Variation for the United States 1855-1980. Rockville, MD: National Ocean Service.

Hoffman, J.S., D. Keyes, and J.G. Titus, 1983. Projecting Future Sea Level Rise, U.S. GPO \#055-000-0236-3. Washington, D.C.: Government Printing Office.

Hoffman, J.S., J.B. Wells, and J.G. Titus, 1986. "Future Global Warming and Sea Level Rise." In Iceland Coastal and River Symposium, edited by F. Sigbjarnarson. Rekjavik: National Energy Authority.

Howard, J.D., O.H. Pilkey, and A. Kaufman, 1985. "Strategy for Beach Preservation Proposed." Geotimes 30(12):15-19.

Hughes, T., 1983. "The Stability of the West Antarctic Ice Sheet: What Has Happened and What Will Happen." In Proceedings: Carbon Dioxide Research Conference: Carbon Dioxide, Science, and Consensus, DOE Conference 820970. Washington, D.C.: Department of Energy.

Kaye, A. and E.S. Barghoorn, 1964. "Late Quaternary Sea Level Change and Coastal Rise at Boston, Massachusetts, with Notes on the Subcompaction of Peat." Geological Society of America, Bulletin 75:63-80.

Keeling, C.D., R.B. Bacastow, and T.P. Whorf, 1982. "Measurements of the Concentration of Carbon Dioxide at Mauna Loa, Hawaii." Carbon Dioxide Review 1982, edited by W. Clark. New York: Oxford University Press, 377-382.

Lacis, A., J.E. Hansen, P. Lee, T. Mitchell, and S. Lebedeff, 1981. "Greenhouse Effect of Trace Gases, 1970-80." Geophysical Research Letters 8(10):1035-1038.

Leatherman, S.P., 1982. Barrier Island Handbook, College Park, Md: University of Maryland.

Maine Department of Environmental Protection, 1987. Sand Dune Rule 355. Augusta: Department of Environmental Protection.

Meier, M.F., et al. 1984. "Contribution of Small Glaciers to Global Sea Level." Science 226:4681, 1418-21.

Meier, M.F., et al. 1985. Glaciers, Ice Sheets and Sea Level: Effect of a $\mathrm{CO}_{2}$-Induced Climatic Change. Washington, D.C.: National Academy Press.

Mercer, J.H., 1970. "Antarctic Ice and Interglacial High Sea Levels." Science 160:1605-1606.

Milliman, J.D., and R.H. Meade, 1983. "World-Wide Delivery of River Sediment to the Oceans," Joumal of Geology 91(1):1-21.

Milliman, J.D. (in press). "Tropical River Discharge to the Sea: Present and Future Impacts from Man's Activities." Tropical Marine Environments, edited by A.J. Phillips. London: Open University Press.

National Oceanic and Atmospheric Administration (NOAA), 1985. Tide Tables 1986. Rockville, MD: National Ocean Service. 
Nordhaus, W.D., and G.W. Yohe, 1983. "Future Carbon Dioxide Emissions from Fossil Fuels." In Changing Climate. Washington, D.C.: National Academy Press.

Pendland, S., J.R. Suter, and T.S. Maslow, 1986. "Holocene Geology of the Ship Shoal Region, Northern Gulf of Mexico." Baton Rouge: Louisiana Geological Survey. Bulletin \#1.

Ramanathan, V., H.B. Singh, R.J. Cicerone, and J.T. Kiehl, 1985. "Trace Gas Trends and Their Potential Role in Climate Change." Joumal of Geophysical Research (August).

Redelfs, A.E., 1983. "Wetlands Values and Losses in the United States." M.S. Thesis. Stillwater: Oklahoma State University.

Redfield, A. C. 1967. "Postglacial Change in Sea Level in the Western North Atlantic Ocean." Science 157:687.

Revelle, R., 1983. "Probable Future Changes in Sea Level Resulting From Increased Atmospheric Carbon Dioxide." In Changing Climate. Washington, D.C.: National Academy Press (does not include Antarctica).

Seidel, S. and D. Keyes, 1983. Can We Delay a Greenhouse Warming? Washington, D.C.: Government Printing Office.

Smagorinsky, J., Chairman, Climate Research Board, 1982. Carbon Dioxide: A Second Assessment. Washington, D.C.: National Academy Press.

South Carolina Coastal Council, 1985. Performance Report of the South Carolina Coastal Management Program. Columbia, South Carolina: South Carolina Coastal Council.

Terrebonne Parish, 1984. "Terrebonne Parish: The Land, the Sea, and the People." Audio Visual Slide Show available from James Edmonson, Terrebonne Parish Council Staff, Houma, Louisiana.

Teal, J and M. Teal, 1969. Life and Death of the Salt Marsh. New York: Random House.

Thomas, R.H., 1985. "Responses of the Polar Ice Sheets to Climatic Warming." In Meier, 1985. op. cit.

Thomas, R.H., 1986. "Future Sea Level Rise and Its Early Detection by Satellite Remote Sensing." In J.G. Titus (ed.), 1986, Effects of Changes in Stratospheric Ozone and Global Climate, Vol. 4: Sea Level Rise.

Tiner, R.W., 1984. Wetlands of the United States: Current Status and Recent Trends. Washington, D.C.: Government Printing Office; Newton Corner, Massachusetts: U.S. Fish and Wildlife Service.

Titus, J.G., 1986. "Greenhouse Effect, Sea Level Rise, and Coastal Zone Management." Coastal Zone Management Joumal 14:3.

Turner, R.E., R. Costanza, and W. Scaife, 1982. "Canals and Wetland Erosion Rates in Coastal Louisiana. In Boesch, op. cit.

UNEP, WMO, ICSU, 1985. United Nations Environment Programme, World Meteorological Organization, and International Council of Scientific Unions. International Assessment of the Role of Carbon Dioxide and of Other Greenhouse Gases in Climate Variations and Associated Impacts. Geneva, Switzerland: United Nations Environment Programme (Conference Statement).

Untersteiner, N., 1975. "Sea Ice and Ice Sheets: Role in Climatic Variations." Physical Basis of Climate Modeling (April), Series 16:206-224.

U.S. Environmental Protection Agency and Louisiana Geological Survey, 1987. Saving Louisiana's Coastal Wetlands: The Need for a Long-Term Plan of Action (Report of the Louisiana Wetland Protection Panel). Washington, D.C.: USEPA.

Wicker, K., M. DeRouen, D. O'Connor, E. Roberts, and J. Watson, 1980. Environmental Characterization of Terrebonne Parish: 1955-1978. Baton Rouge: Coastal Environments, Inc.

Wuebbles, D.J., M.C. MacCracken, and F.W. Luther, 1984. A Proposed Reference Set of Scenarios for Radiatively Active Atmospheric Constituents. Washington, D.C.: Carbon Dioxide Research Division, U.S. Department of Energy. 



\title{
Chapter 2
}

\section{CHARLESTON CASE STUDY}

\author{
by \\ Timothy W. Kana, Bart J. Baca, and Mark L. Williams \\ Coastal Science \& Engineering, Inc. \\ P.O. Box 8056 \\ Columbia, South Carolina 29202
}

\section{INTRODUCTION}

This chapter examines the potential impact of future sea level rise on coastal wetlands in the area of Charleston, South Carolina, for the year 2075. We investigate the hypothesis from Chapter 1 that a generally concave marsh profile implies that a rise in sea level would cause a net loss of wetlands. The chapter builds upon previous EPA studies that had assessed the potential physical and economic impacts of sea level rise on the Charleston area.

We surveyed twelve wetland transects to determine elevations of particular parts of the marsh, frequency of flooding, and vegetation at various elevations. From these transects, we developed a composite transect representing an average profile of the area. Using this information and estimates of the sediment provided by nearby rivers, we then estimated the shifts in wetland communities and net loss of marsh acreage associated with three possible scenarios of sea level rise for the year 2075: (1) the current trend, which implies a rise of $24 \mathrm{~cm}(0.8 \mathrm{ft})$, relative to the subsiding coast of Charleston; (2) a low scenario of $87 \mathrm{~cm} \mathrm{(3.0} \mathrm{ft);} \mathrm{and} \mathrm{(3)} \mathrm{a} \mathrm{high}$ scenario of a $159-\mathrm{cm}$ rise $(5.2 \mathrm{ft})$. $^{1}$

We examine background information concerning global warming and future sea level rise, the ecological balance of coastal wetlands, and the potential transformation of these ecosystems as sea level rises. Next, we examine the wetlands in the Charleston study area and describe a field study in which we developed wetland transects. Finally, we discuss the potential impact of future sea level rise on Charleston's wetlands, and suggest ways to improve our ability to predict the impact of sea level rise on other coastal wetlands.

\section{Ecological Balance of Wetlands}

Recent attention concerning rising sea level has been focused on the fate of economic development in coastal areas. However, the area facing the most immediate consequences would be intertidal wetlands. Lying between the sea and the land, this zone will experience the direct effects of changing sea levels, tidal inundation, and storm surges.

The intertidal wetlands contain productive habitats, including marshes, tidal flats, and beaches, which are essential to estuarine food webs. The distribution of the wetlands is sensitively balanced for existing tidal conditions, wave energy, daily flooding duration, sedimentation rates (and types), and climate. Their elevation in relation to mean sea level is critical to determining the boundaries of a habitat and the plants within it, because elevation affects the frequency, depth, and duration of flooding and soil salinity. For example, some marsh plants require frequent (daily) flooding, while others adapt to irregular or infrequent flooding (Teal 1958). Along the U.S. East Coast, the terms "low marsh" and "high marsh" are often used to distinguish between zones (Teal 1958; Odum and Fanning 1973) that are flooded at least daily and zones flooded less than daily but at least every 15 days. Areas flooded monthly or less are known as transition wetlands. 
Regularly flooded marsh in the southeast United States is dominated by stands of smooth cordgrass (Spartina alterniflora), which may at first appear to lack zonation. However, work by Teal (1958), Valiela, Teal, and Deuser (1978), and others indicates total biomass varies considerably within the low marsh, ranging from zones of tall S. altermiflora along active creek banks to stunted or short S. altemiflora stands away from creeks and drainage channels. The tall S. alterniflora may be caused by a combination of factors, including more nutrients, a higher tolerance for the reductions in oxygen that result from subtle increases in elevation along levees (DeLaune, Smith, and Patrick 1983), and differences in drainage created by variations in the porosity of sediment. The zone where $S$. alterniflora grows is thought by many to be limited in elevation to mean high water. This is probably too broad a simplification according to Redfield (1972), who emphasized that the upper boundary of the low marsh is, at best, indistinct.

High marsh, in contrast, consists of a variety of species. These include Salicomia spp. (glassworts), Distichlis spicata (spikegrass), Juncus spp. (black needlerush), Spartina patens (saltmarsh hay), and Borrichia frutescens (sea oxeye). Teal (1958) reports that Juncus marsh tends to be found at a slightly higher elevation than the Salicomia/Distichlis marsh.

The high marsh can also be distinguished from low marsh on the basis of sediment type, compaction, and water content. High-marsh substrate tends to be firmer and dryer and to have a higher sand content. Low-marsh substrate seldom has more than 10 percent sand (except where barrier-island washover deposits introduce an "artificial" supply) and is often composed of very soft mud. Infrequent flooding, prolonged drying conditions, and irregular rainfall within the high marsh also produce wide variations in salinity. In some cases, salt pannes form, creating barren zones. But at the other extreme, frequent freshwater runoff may allow less salt-tolerant species, such as cattails, to flourish close to the salt-tolerant vegetation. These factors contribute to species diversity in the transition zone that lies between $S$. alterniflora and terrestrial vegetation.

By most reports, low marsh dominates the intertidal areas along the southeast (Tumer 1976), but the exact breakdown can vary considerably from place to place. Wilson (1962) reported S. alterniflora composes up to 28 percent of the wetlands in North Carolina, whereas Gallagher, Reimold, and Thompson (1972) report for one estuary in Georgia that the same species covers 94 percent of the "marsh" area. Low marsh is thought by many to have a substantially higher rate of primary productivity than high marsh (Turner 1976). Data presented in Odum and Fanning (1973) for Georgia marshes support this notion. However, Nixon (1982) presents data for New England marshes that indicate above-ground biomass production in high marshes comparable to that of low marshes. Some data from Gulf Coast marshes also support this view (Pendleton 1984).

\section{Potential Transformation of Wetlands}

The late Holocene (last several thousand years) has been a time of gradual infilling and loss of water areas (Schubel 1972). During the past century, however, sedimentation and peat formation have kept pace with rising sea level over much of the East Coast (e.g., Ward and Domeracki 1978; Duc 1981; Boesch et al. 1983). Thus, apart from the filling necessary to build the city of Charleston, the zonation of wetland habitats has remained fairly constant there. Changes in the rate of sea level rise or sedimentation, however, would alter the present ecological balance.

If sediment is deposited more rapidly than sea level rises, low marsh will flood less frequently and become high marsh or upper transition wetlands, which seems to be occurring at the mouths of some estuaries where sediment is plentiful. The subtropical climate of the southeastern United States produces high weathering rates, which provide a lot of sediment to the coastal area. Excess supplies of sediment trapped in estuaries have virtually buried wetlands around portions of the Chesapeake, such as the Gunpowder River, where a colonial port is now landlocked.

If sea level rises more rapidly in the future, increased flooding may cause marginal zones close to present low tide to be under water too long each day to allow marshes to flourish. Unless 
sedimentation rates are high wetlands can maintain the distribution of their habitats only if they shift along the coastal profile-moving landward and upward, to keep pace with rising sea levels. Total marsh acreage can only remain constant if slopes and substrate are uniform above and below the wetlands, and inundation is unimpeded by human activities such as the construction of bulkheads. Titus, Henderson, and Teal (1984), however, point out that there is usually less land immediately above wetland elevation than at wetland elevation (See Figure 1-5). Therefore, significant changes in the habitats and a reduction in the area they cover will generally occur with accelerated sea level rise. Moreover, increasing development along the coast is likely to block much of the natural adjustment in some areas.

Louisiana is an extreme example. Human interference with natural sediment processes and relative sea level rise are resulting in the drowning of $100 \mathrm{sq} \mathrm{km}$ of wetlands every year (Gagliano, Meyer Arendt, and Wicker 1981; Nummedal 1982). There is virtually no ground to which the wetlands can migrate. Thus, wetlands are converting to open water; high-marsh zones are being replaced by low marsh, or tidal flats; and saltwater intrusion is converting freshwater swamps and marsh to brackish marsh and open water.

\section{COASTAL HABITATS OF THE CHARLESTON STUDY AREA}

As shown in Figure 2-1, the case study area, stretching across 45,500 acres, is separated by the three major tidal rivers that converge at Charleston: the Ashley, Cooper, and Wando Rivers. In addition, the study area covers five land areas:

- West Ashley, which is primarily a low-density residential area with expansive boundary marsh;

- Charleston Peninsula, which contains the bulkheaded historic district built partly on landfiil;

- Daniel Island, which is an artificially embanked dredge spoil island;

- Mount Pleasant, which derives geologically from ancient barrier island deposits oriented parallel to the coast; and

- Sullivans Island, which is an accreting barrier island at the harbor entrance.

Six discrete habitats are found in the Charleston area, distinguished by their elevation in relation to sea level and, thus, by how often they are flooded (Figure 2-2):

- highland - flooded rarely (47 percent of study area)

- transition wetlands - flooding may range from biweekly to annually (3 percent)

- high marshes - flooding may range from daily to biweekly (5 percent)

- low marshes - flooded once or twice daily (12 percent)

- tidal flats - flooded about half of the day (6 percent)

- open water - (27 percent)

This flooding, in turn, controls the kinds of plant species that can survive in an area. In Charleston, the present upper limit of salt-tolerant plants is approximately $1.8-2.0 \mathrm{~m}(6.0-6.5 \mathrm{ft})$ above mean sea level (Scott, Thebeau, and Kana 1981). This elevation also represents the effective lower limit of human development, except in areas where wetlands have been destroyed. The zone below this elevation (delineated on the basis of vegetation types) is referred to as a critical area under South Carolina Coastal Zone Management laws and is strictly regulated (U.S. Department of Commerce 1979). 
Although most of the marsh in this area is flooded twice daily, the upper limit of salt-tolerant species is considerably above mean high water. Because of the lunar cycle and other astronomic or climatic events, higher tides than average occur periodically. Spring tides occur approximately fortnightly in conjunction with the new and full moons. The statistical average of these, referred to as mean high water spring, has an elevation of $1.0 \mathrm{~m}(3.1 \mathrm{ft})$ above mean sea level in Charleston (U.S. Department of Commerce 1981).

Less frequent tidal flooding occurs annually at even higher elevations ranging upwards of $1.5 \mathrm{~m}(5.0 \mathrm{ft})$ above mean sea level. In a South Carolina marsh near the case study area, the flooding of marginal highland occurred at elevations of 1.5-2 m above mean sea level (approximately $80 \mathrm{~cm}$ above normal). The peak astronomic tide that was responsible for the flooding included an estimated wind setup of $15-20 \mathrm{~cm}(0.5-1.0 \mathrm{ft})$ under $7-9 \mathrm{~m} / \mathrm{s}(13-17 \mathrm{mph})$ northeast winds.

\section{FIGURE 2-1}

\section{CHARLESTON STUDY AREA}
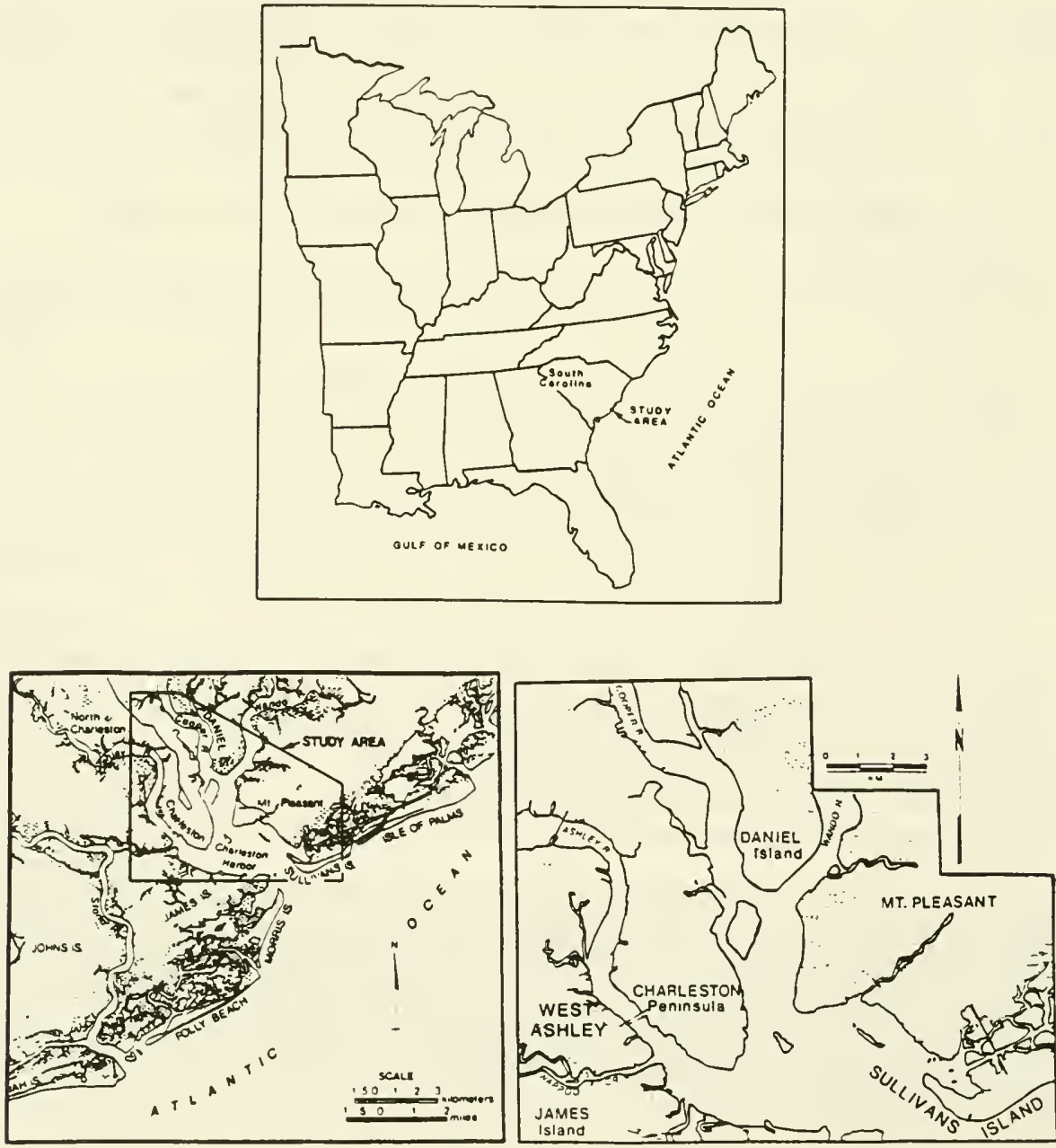


\section{COASTAL WETLAND HABITATS}

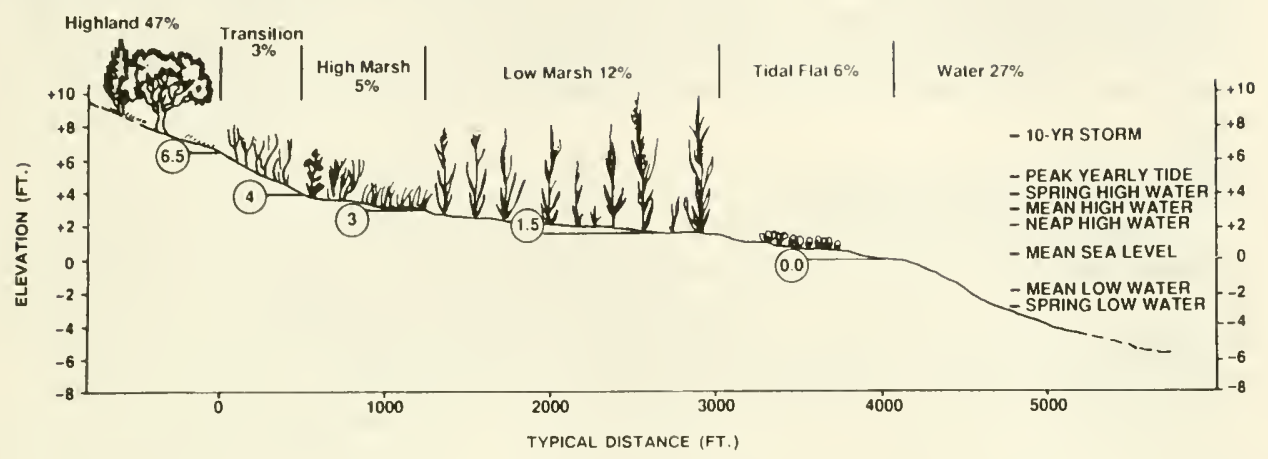

The Charleston area has a complex morphology. Besides the three tidal rivers that converge in the area, numerous channels dissect it, exhibiting dendritic drainage patterns typical of drowned coastal plain shorelines.

A back-barrier, tidal creek/marsh/mud-flat system near Kiawah Island, approximately $20 \mathrm{~km}$ south of Charleston, has a typical drainage pattern. Throughout the area, highlands are typically

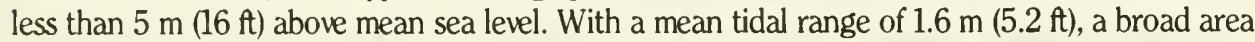
along the coastal edge is flooded twice each day. The natural portions of Charleston Harbor are dominated by fringing salt marshes from several meters to over one kilometer wide.

The upper limit of the marsh can usually be distinguished by an abrupt transition from upland vegetation to marsh species tolerant of occasional salt-water flooding. Topographic maps of Charleston generally show this break to have an elevation of about $1.5 \mathrm{~m}(+5 \mathrm{ft})$. Along the back side of Kiawah Island, just south of the case study area, one can observe such an abrupt transition between highland terrestrial vegetation and the marsh area. Where the waterfront is developed, the transition from marsh or tidal creeks to highland can be very distinct because of the presence of shore-protection structures, such as vertical bulkheads and riprap. Another marsh/tidal-flat system located behind Isle of Palms and Dewees Island, just outside of the Charleston study area, contains a mud flat and circular oyster mounds near the marsh and tidal channels. Oyster mounds were found at a wide range of elevations along tidal creek banks, but over tidal flats most were common at elevations of $30-46 \mathrm{~cm}(1.0-1.5 \mathrm{ft})$.

Large portions of the back-barrier environments of Charleston consist of tidal flats at lower elevations than the surrounding marsh. The most extensive intertidal mud flats around Charleston generally occur in the sheltered zone directly behind the barrier islands. They are thought to represent areas with lower sedimentation rates (Hayes and Kana 1976) away from major tidal channels or sediment sources.

Much of the Charleston shoreline has accreted (advanced seaward and upward) during the past 40 years (Kana et al. 1984). Marshes accrete through the settling of fine-grained sediment on the marsh surface, as cordgrass (Spartina alterniflora) and other species baffle the flow adjacent to tidal creeks. Marsh sedimentation has generally been able to keep up with or exceed recent sea level rises along this area of the eastern U.S. shoreline (Ward and Domeracki 1978). Much of the sediment into the Charleston area derives from suspended sediment originating primarily from the Cooper River, which carries the diverted flow of the Santee River (until planned rediversion in 1986; U.S. Army Corps of Engineers, unpublished general design memorandum). 


\section{WETLANDS TRANSECTS: METHOD AND RESULTS}

To determine how an accelerated rise in sea level would affect the wetlands of Charleston, one needs to know the portions of land at particular elevations and the plant species found at those elevations. To characterize the study area, we randomly selected and analyzed twelve transects (sample cross sections, each running along a line extending from the upland to the water). This section explains how the data from each transect were collected and analyzed, presents the results from each transect, and shows how we created a composite transect based on those results.

\section{Data Collection and Analysis}

For budgetary and logistical reasons, we had to use representative transects near, but not necessarily within, the study area. For example, a limiting criterion was nearness to convenient places where reliable elevations, or benchmarks, had already been established. The marshes behind Kiawah Island and Isle of Palms are similar to the marshes behind Sullivans Island, but are more accessible. As Figure 2-3 shows, all the transects were within $20 \mathrm{~km}$ (12 mi) of the study area.

Each transect began at a benchmark located on high ground near a marsh's boundary, and ended at a tidal creek or mud flat, or after covering $300 \mathrm{~m}(1,000 \mathrm{ft})$-whichever came first. The length of the transects was limited because of the difficulty of wading through very soft muds. Although this procedure may have biased the sample somewhat, logistics prevented a more rigorous survey.

\section{FIGURE 2-3}

\section{LOCATIONS OF STUDY AREA'S TWELVE TRANSECTS}

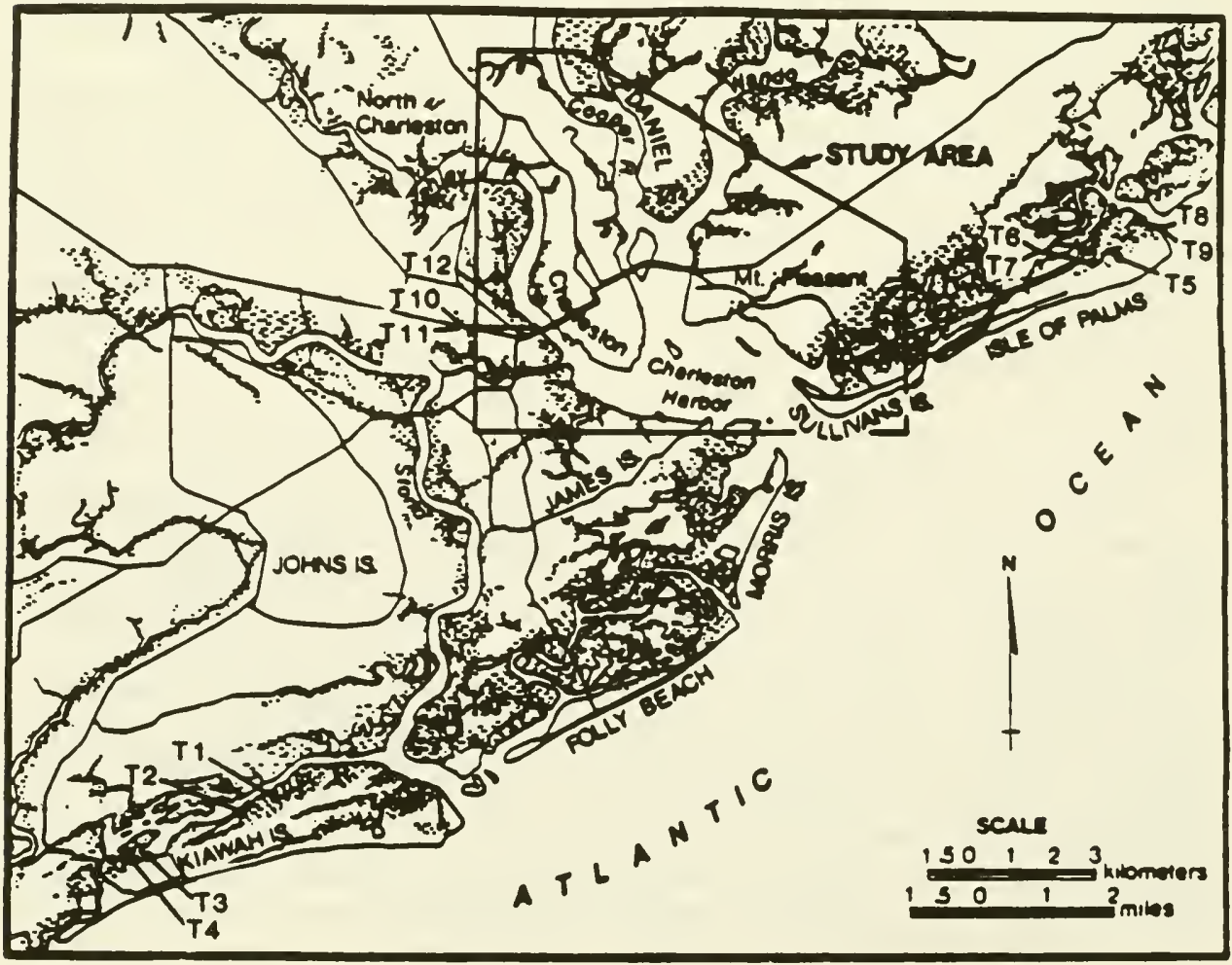


For each transect, we measured elevation and distance from a benchmark using a rod and level. Elevations were sunveyed wherever there was a noticeable break in slope or change in species. The average distance between points was about $7.5 \mathrm{~m}(25 \mathrm{ft})$. Along each transect we collected and tagged samples of species for laboratory typing and verification, noting such information as the elevation of the boundaries between different species. By measuring the length of the transect that a species covered and dividing it by the transect's total length, we computed percentages for the distribution of each species along a transect.

\section{Results of Individual Transects}

Table 2-1 (see page 44) summarizes the results of the twelve transects. ${ }^{2}$ It presents the principal species observed along each transect, their "modal"-or most common-elevations, the percentage of each transect they covered, and the length of each transect. For example, in transect number 6 , Borrichia frutescens was found at a modal elevation of $118 \mathrm{~cm}(3.86 \mathrm{ft})$ and covered 40 percent of the transect, or about $37 \mathrm{~m}(120 \mathrm{ft})$.

Because species often overlapped, the sums of the percentages exceed 100. In addition, to omit any marginal plants that exist at transition zones, a modal elevation differs slightly from the arithmetic or weighted mean.

\section{Composite Transect}

To model the scenarios of future sea level rise, we had to develop a composite transect from the data in Table 2-1. Thus, for each species, one modal elevation was estimated from the various elevations in Table 2-1. Similarly, the percent of each transect covered by an individual species was used to estimate an average percent coverage for all transects (Table 2-2, p. 45).

This information allowed us to choose for our composite the five species that dominated the high and low marshes in all the transects: Spartina alterniflora, Salicomia virginica, Limonium carolinianum, Distichlis spicata, and Borrichia frutescens. We call these the indicator species. Figure $2-4$ shows the modal elevations for these five species, for two other salt-tolerant plants found in the transects (Juncus roemerianus and Spartina patens), and for a species found in tidal flats and under water (Crassostrea virginica). The primary zone where each species occurs is indicated by the shaded area; occasional species occurrence outside the primary zone is indicated by the unshaded, dashed-line boxes. Figure $2-4$ also outlines the boundaries for the six habitats and indicates the estimated percentage of the study area that each covers.

\section{FIGURE 2-4}

\section{COMPOSITE TRANSECT-CHARLESTON, S.C.}

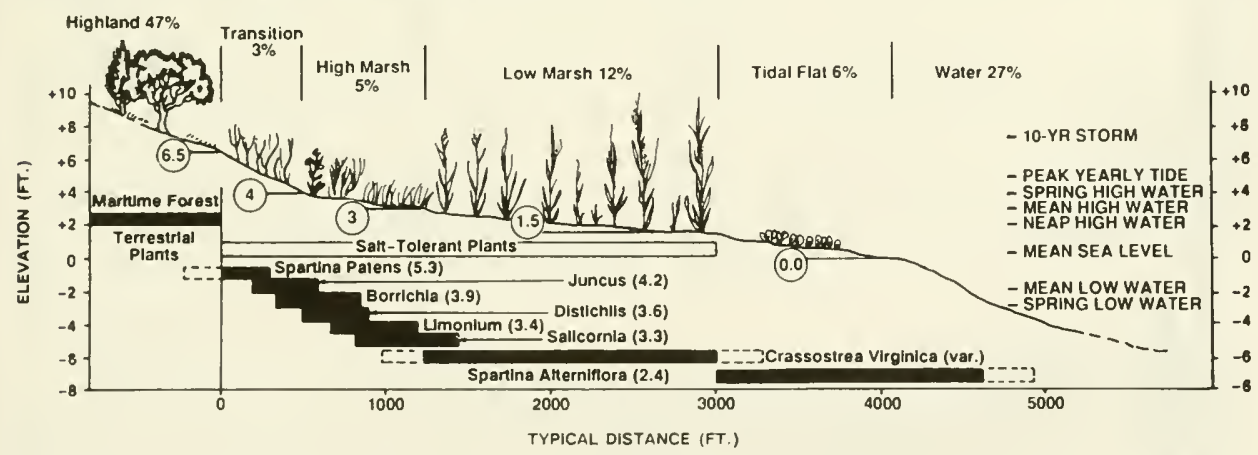

Composite wetlands transect for Charleston illustrating the approximate percent occurrence and modal elevation for key indicator species or habitats based on results of 12 surveyed transects. Minor species have been omitted. Elevations are with respect to NGVD, which is about $15 \mathrm{~cm}$ lower than current sea level. Current tidal ranges are shown at right. 


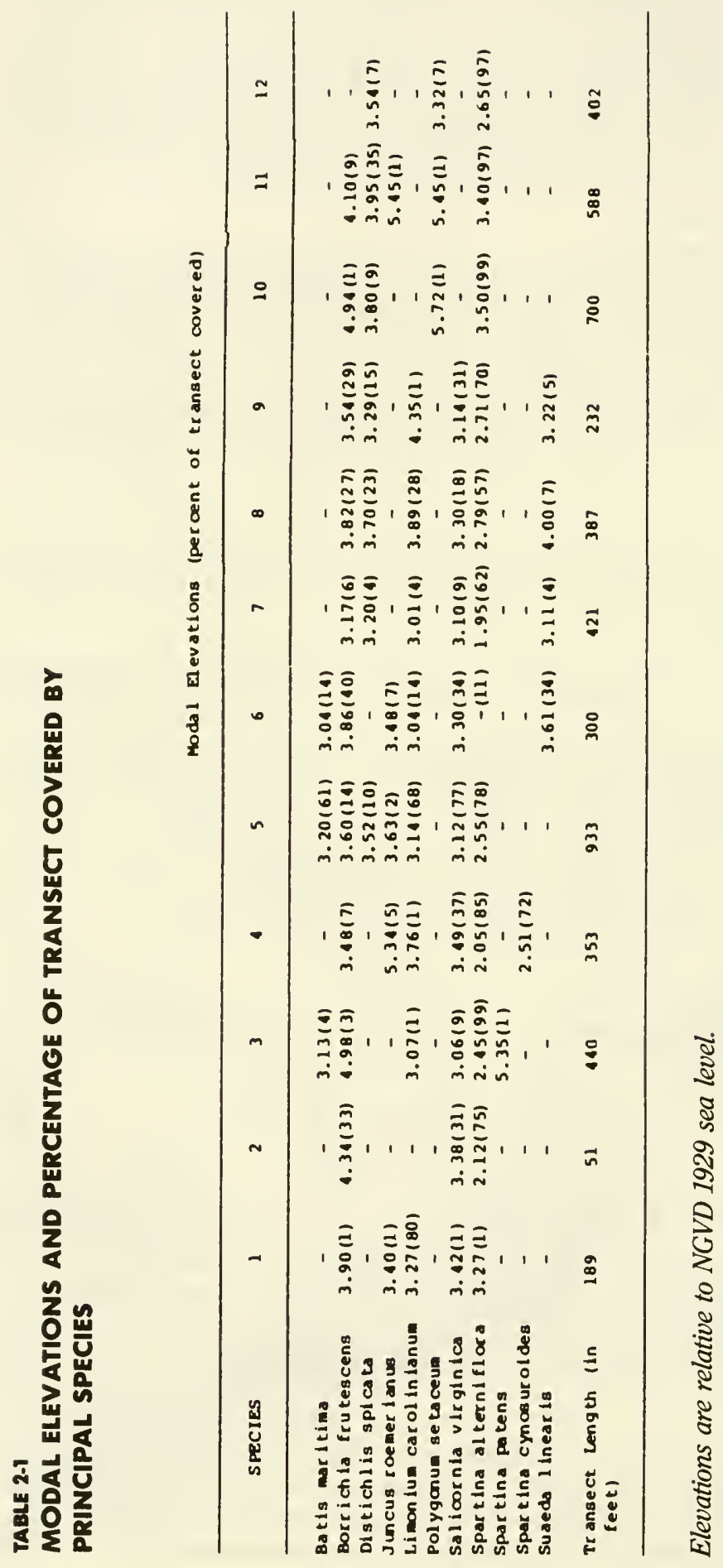




\begin{tabular}{|c|c|c|c|c|}
\hline SPECIES & $\begin{array}{c}\text { Weighted Mean } \\
\text { (feet above NGVD) }\end{array}$ & $\begin{array}{c}\text { Standard } \\
\text { Deviation } \\
( \pm f t)\end{array}$ & $\begin{array}{l}\text { Modal } \\
\text { Elevation }\end{array}$ & $\begin{array}{c}\text { Percent } \\
\text { Occurrence } \\
\text { Composite }\end{array}$ \\
\hline Batis maritima & - & - & 3.17 & 7 \\
\hline Borrichia frutescens & 3.76 & .53 & $3.16+7$ & $14 \% \div$ \\
\hline Distichlis spicata & 3.71 & .27 & $3.71 \div$ & $9 *+4$ \\
\hline Juncus roemerianus & - & - & 4.17 & 1 \\
\hline Limonium carolinianum & 3.38 & .46 & $3.38+t x$ & $16 \div \div$ \\
\hline Polygonum setaceum & - & - & 3.32 & 1 \\
\hline Salicornia virginica & 3.18 & .20 & $3.16 \div$ & $21 \div$ \\
\hline Spartina alterniflora & 2.59 & .59 & $2.45 * *$ & 69-69) \\
\hline Spartina patens & - & - & 5.35 & $<1$ \\
\hline Spartina cynosuroides & - & - & 2.51 & 6 \\
\hline Suaeda linearis & - & - & 3.59 & 4 \\
\hline
\end{tabular}

Excludes anomalous values in some cases and observations courring less than 2 percent of transect.

- Recommended indicator species.

While this profile is by no means precise, it gives some insight into the expected habitat for a given elevation and the tolerances various species have for flooding. For example, it establishes the general lower limit of marsh for Charleston, where it is presumed that too frequent flooding kills low-marsh species and transforms the marsh to unvegetated mud flats.

The low-marsh plant Spartina altemiflora was the most dominant species, making up 69 percent of the composite transect. Its modal elevation was $75 \mathrm{~cm}(2.45 \mathrm{ft})$, close to today's neap high tide. For Charleston, this is about $15 \mathrm{~cm}(0.5 \mathrm{ft})$ below mean high water. Figure $2-4$ shows that $S$. altemiflora extends beyond the limits of low marsh into both high marsh and tidal flat; however, this species occurs primarily at low-marsh elevations.

The other indicator species are generally considered to be high-marsh species. These include Distichlis spicata, Borrichia frutescens, Limonium carolinianum and Salicomia virginica. Spartina patens, while having been found to coexist with Distichlis spicata in Maryland and North Carolina marshes (E.C. Pendleton, personal communication, December 1984), is uncommon in Charleston at elevations less than $122 \mathrm{~cm}$ (Scott, Thebeau, and Kana 1981). The apparent inconsistency in these observations may be related to the significant difference in tidal range between central South Carolina and North Carolina.

\section{Area Estimates}

Two sources of information were available for land area estimates: United States Geological Survey (USGS) 7.5-minute quadrangles and digitized computer maps prepared in an earlier EPAsponsored case study (Kana et al. 1984). Using topographic and contour maps, we estimated the number of acres of each habitat in the Charleston area (see Figure 2-1). ${ }^{4}$

Our results were graphically determined and spot-checked by a second investigator to ensure they were consistent to within \pm 15 percent for each measurement. Thus, the error limits for the overall study area are estimated to be a maximum of \pm 15 percent by subenvironment. ${ }^{5}$ 
Tidal-flat areas were estimated using aerial photos and shaded patterns shown on USGS topographic sheets. The marsh was initially lumped together (high and low marsh) to determine representative areas for each Charleston community. The total number of acres for this zone was divided into high- and low-marsh areas by applying the typical percentage of each along the composite transect ( 70 percent low marsh and 30 percent high marsh). The transition zone areas were estimated from the digitized computer maps.

\section{WETLAND SCENARIOS FOR THE CHARLESTON AREA: MODELING AND RESULTS}

After establishing the basic relationships among elevation, wetland habitats, and occurrence of species for Charleston, the next steps in our analysis were to develop a conceptual model for changes in saltwater wetlands under an accelerated rise in sea level and to apply the model to the case study area.

\section{Scenario Modeling}

Based on an earlier EPA study (Barth and Titus 1984), we chose three scenarios of future sea level rise (described in Chapter 1, page 9): baseline (current trends), low, and high. ${ }^{6}$ To be consistent with the study, we projected the scenarios to the year 2075-95 years after the baseline date of 1980 used to determine "present" conditions; we also assumed that the current rate of relative sea level rise in Charleston is $2.5 \mathrm{~mm} / \mathrm{yr}$, although more recent studies suggest 3.4 $\mathrm{mm} / \mathrm{yr}$.

The model for future wetland zonation also accounted for sedimentation and peat formation, which partially offset the impact of sea level rise by raising the land surface. Sedimentation rates are highly variable within East Coast marsh/tidal-flat systems, with published values ranging from 2 to $18 \mathrm{~mm}$ (.08 to .71 in) per year (Redfield 1972; Hatton, DeLaune, and Patrick 1983). Ward and Domeracki (1978) established markers in an intertidal marsh $20 \mathrm{~km}(12$ mi) south of the Charleston case study area and measured sedimentation rates of 4-6 mm (.16-.24 in) per year. Hatton, DeLaune, and Patrick (1983) reported comparable values $(3-5 \mathrm{~mm}$, or .12-20 in, per year) for Georgia marshes. Although the rate of marsh accretion will depend on proximity to tidal channels (sediment sources) and density of plants (baffling effect and detritus), we believe the published rate of $4-6 \mathrm{~mm}$ per year is reasonably representative for the case study area (Ward and Domeracki 1978). Thus, for purposes of modeling, we assumed a sedimentation rate of $5 \mathrm{~mm}$ per year. Obviously, the actual rate will vary across any wetland transect, so this assumed value represents an average. Lacking sufficient quantitative data and considering the broad application of our model, we found it was more feasible to apply a constant rate for the entire study area.

As shown in Table 2-3, the combined sea level rise scenarios and sedimentation rates yield a positive change in substrate elevation for the baseline and a negative change for the low and high scenarios. The positive change for baseline conditions follows the recent trend of marsh accretion in Charleston.

For each of these three scenarios, we considered four alternatives for protecting developed uplands from the rising sea: no protection, complete protection, and two intermediate protection options. Protective options consist of bulkheads, dikes, or seawalls constructed at the lower limit of existing development, which is generally the upper limit of wetlands (S.C. Coastal Council critical area line). Figure 2-5 illustrates the various options. If all property above today's wetlands is protected with a wall, for example, the wetlands will be squeezed between the wall and the sea. Table $2-4$ illustrates the intermediate protection options, whose economic implications were estimated by Gibbs (1984). 
SEA LEVEL RISE SCENARIOS TO THE YEAR 2075

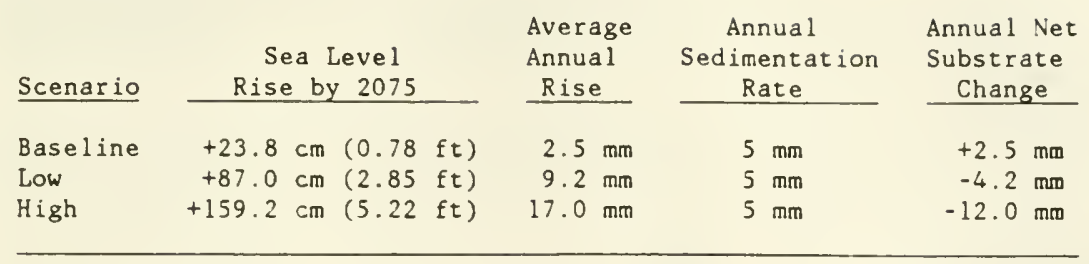

ILLUSTRATION OF HOW SHORE PROTECTION AFFECTS WETLANDS

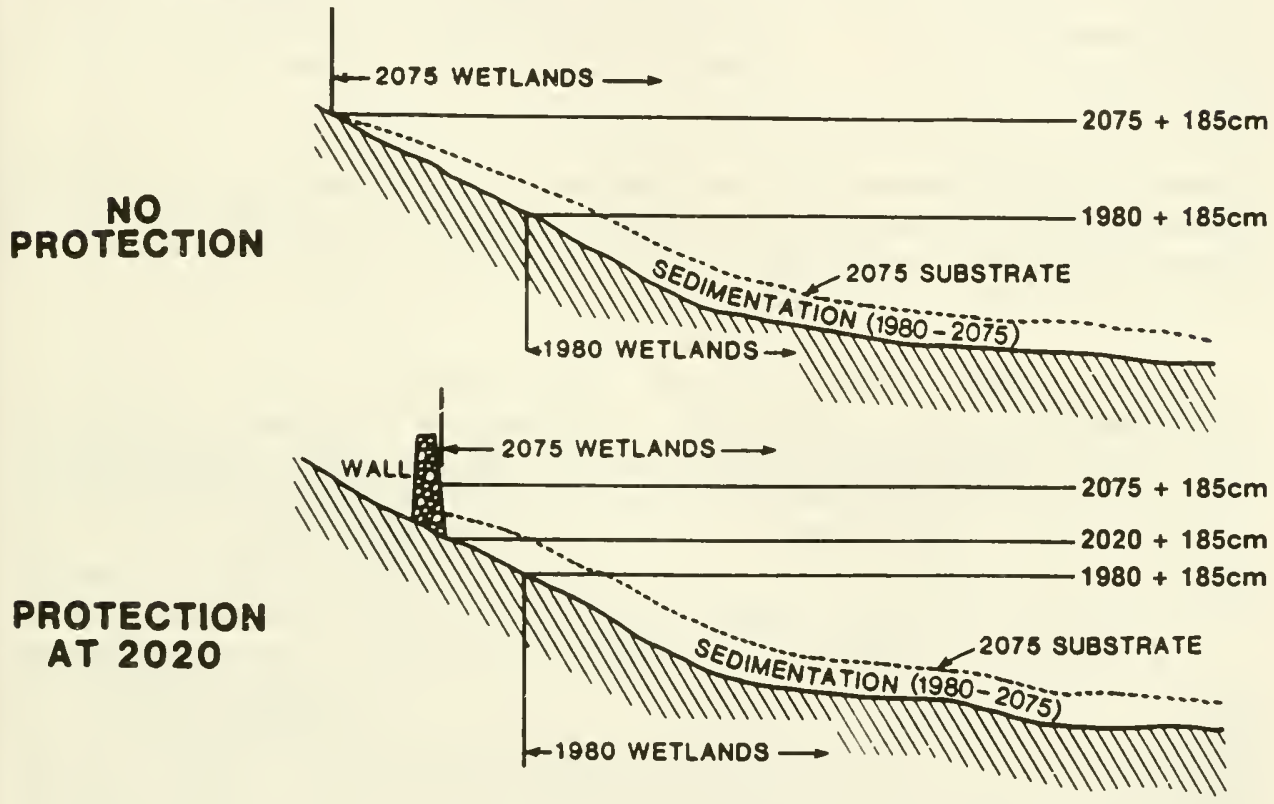

PROTECTION

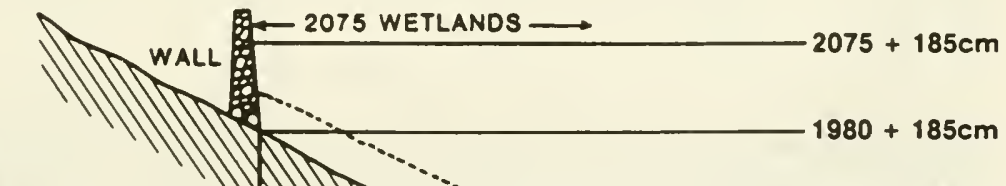
AT 1980

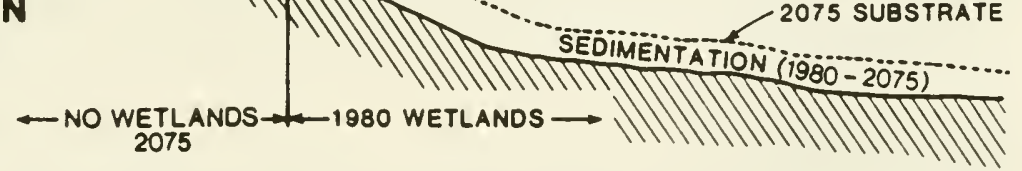

If people build walls to protect property from rising sea level, the marsh will be squeezed between the wall and the sea. Sketches show only the upper part of the wetlands which would be affected by shore-protection structures. Mean sea level is off the diagram to the right. 


\begin{tabular}{|c|c|c|}
\hline Area & $\begin{array}{l}\text { Without Anticipating } \\
\text { Sea Level Rise } \\
\end{array}$ & $\begin{array}{l}\text { With Anticipating } \\
\text { Sea Level Rise } \\
\end{array}$ \\
\hline \multicolumn{3}{|l|}{ Low Scenario } \\
\hline $\begin{array}{l}\text { Peninsula } \\
\text { West Ashley/James Is land }\end{array}$ & $\begin{array}{l}\text { Protection after } 2050 \\
\text { Protection after } 2050\end{array}$ & $\begin{array}{l}\text { Protection after } 2030 \\
\text { Protect half of area } \\
\text { after } 2050\end{array}$ \\
\hline $\begin{array}{l}\text { Mt. Pleasant } \\
\text { Sullivans Is land }\end{array}$ & $\begin{array}{l}\text { None } \\
\text { None }\end{array}$ & $\begin{array}{l}\text { Protection after } 1990 \\
\text { None }\end{array}$ \\
\hline \multicolumn{3}{|l|}{ High Scenario } \\
\hline $\begin{array}{l}\text { Peninsula } \\
\text { West Ashley/James Island }\end{array}$ & $\begin{array}{l}\text { Protection after } 2020 \\
\text { Protection after } 2020\end{array}$ & $\begin{array}{l}\text { Protection after } 2010 \\
\text { Protect half of area } \\
\text { after } 2030\end{array}$ \\
\hline $\begin{array}{l}\text { Mt. Pleasant } \\
\text { Sullivans Is land }\end{array}$ & $\begin{array}{l}\text { Protection after } 2050 \\
\text { None }\end{array}$ & $\begin{array}{l}\text { Protection after } 1990 \\
\text { None }\end{array}$ \\
\hline
\end{tabular}

Note: In West Ashley/James Island, less protection is necessary if sea level rise is anticipated, because more of the low-lying areas are subject to an orderly abandonment.

Source: Gibbs 1984. (Note that Gibbs called our high scenario "medium.")

For our modeling, we used the composite habitat elevations we derived from the twelve transects (see Figure 2-4). The cutoff elevation for highland around Charleston was assumed to be an elevation of $200 \mathrm{~cm}(6.5 \mathrm{ft})$. In general, land above this elevation around Charleston is free of yearly flooding and is dominated by terrestrial (freshwater) vegetation. Although terrestrial vegetation occurs at lower elevations that are impounded between dikes or ridges, this information is less relevant for sea level rise modeling. The zone of concern is the area bordering tidal waterways, where slopes are assumed to rise continuously without intermediate depressions.

The transition zone is defined as a salt-tolerant area between predominant, high-marsh species and terrestrial vegetation. This area is above the limit of fortnightly (spring) tides but is generally subject to flooding several times each year. If storm frequency remains constant, it is reasonable to assume that storm tides will shift upward by the amount of sea level rise (Titus et al. 1984). However, most climatologists expect the greenhouse warming to alter storm patterns significantly. Nevertheless, because no predictions are available, we assumed that storm patterns will remain the same.

High marsh is defined here by a narrow elevation range of 90 to $120 \mathrm{~cm}$ ( 3 to $4 \mathrm{ft}$ ), and low marsh ranges from 45 to $90 \mathrm{~cm}(1.5$ to $3.0 \mathrm{ft}$ ). This delineation follows the results of surveyed transects and species zonation described earlier. The lower limit of the marsh was estimated from the typical transition to mud flats. Sheltered tidal flats actually occur between mean low water and mean high water but were found to be more common in Charleston in the elevation range of $0-46 \mathrm{~cm}(0-1.5 \mathrm{ft})$. This somewhat arbitrary division was also based on the contours available on USGS maps, which enabled estimates of zone areas within the case study region.

\section{Scenario Results}

Based on the shore-protection alternatives for the five suburbs around Charleston, we computed area distributions under the baseline, low, and high scenarios. Figure 2-5 illustrates shore-protection scenarios and their effects on the wetland transect. Our basic assumption was that the wetland habitats' advance toward land ends at $200 \mathrm{~cm}$ NGVD $(185 \mathrm{~cm}$ above mean sea 
level). Dikes or bulkheads would be constructed under certain protection scenarios at that elevation on the date in question to prevent further inundation.

Because the results are fairly detailed for the five separate subareas and four protection scenarios within the Charleston case study area, we have only listed the overall changes in Tables $2-5$ and 2-6 (complete protection and no protection, see p. 50). Results by subarea for all four protection scenarios, given in Appendix 2-B, illustrate the variability of land, water, and wetland acreage from one subarea to another. For example, the peninsula currently has a much lower percentage of low marsh than all other areas. Tidal flat distribution was also variable, ranging from 3.2 percent of the Mt. Pleasant zone to 8.6 percent of the Sullivans Island zone. The summary percentages given in Table 2-6 are appropriately weighted for the five subareas within the study area.

Table 2-5 lists the number of acres for each elevation zone in 1980 (existing) and for the baseline, low, and high scenarios with and without structural protection by the year 2075. The percentage of the total study area that a habitat covers is given in parentheses in Table 2-5 and graphically presented in Figure 2-6, below. Table 2-5 indicates losses under all scenarios with no protection for the four upper habitats and gains in area for tidal flats and water areas. For example, without protection, highland would decrease from 46.6 percent of the total area in 1980 to 41.7 percent in 2075 under the high scenario. This represents a loss of over 2,200 acres or 10 percent of the present highland area. Land that is now terrestrial would be transformed into transition-zone or high-marsh habitats a century from now. Under the 2075 high scenario with no protection, high and low marsh, combined, would decrease from 7,700 acres to 1,535 acres-a reduction of almost 80 percent. While highland and marsh areas would decrease under the no-protection scenarios, water areas would increase dramatically-from 27.4 percent to as much as 48.7 percent-under the high scenario of 2075 .

\section{FIGURE 2.6}

\section{SHIFT IN WETLANDS ZONATION ALONG A SHORELINE PROFILE}

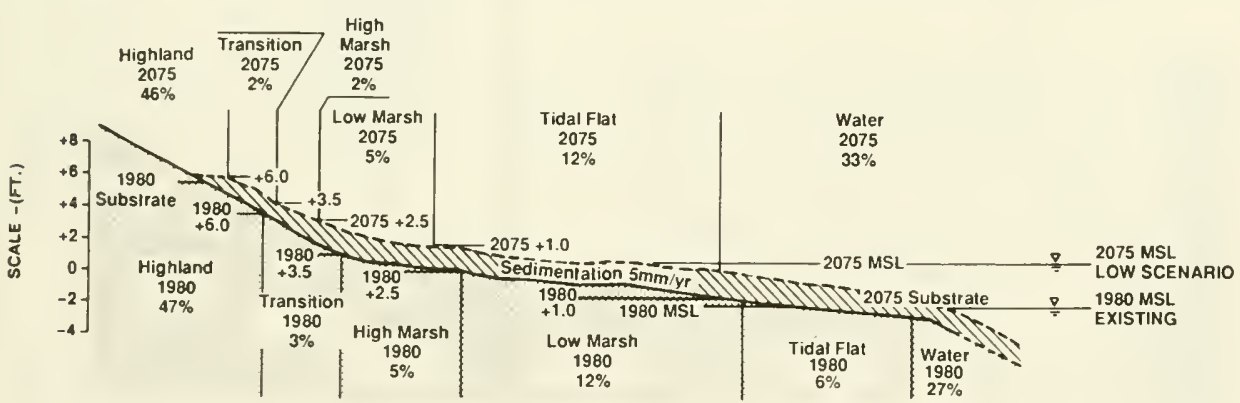

Conceptual model of the shift in wetlands zonation along a shoreline profile if sea level rise exceeds sedimentation by $40 \mathrm{~cm}$. In general, the response will be a landward shift and altered areal distribution of each habitat because of variable slopes at each elevation interval.

With structural protection implemented at different times for each community (see Table 2-4), highland areas would be maintained at a constant acreage, but transition and high-marsh habitats would be completely eliminated by 2075 under the high scenario (because of the lack of area to accommodate a landward shift). Total marsh acreage would decrease from 7,700 acres to 3,925 acres (2075 low scenario), or 750 acres (2075 high scenario), under the assumed mitigation in Table $2-4$. 


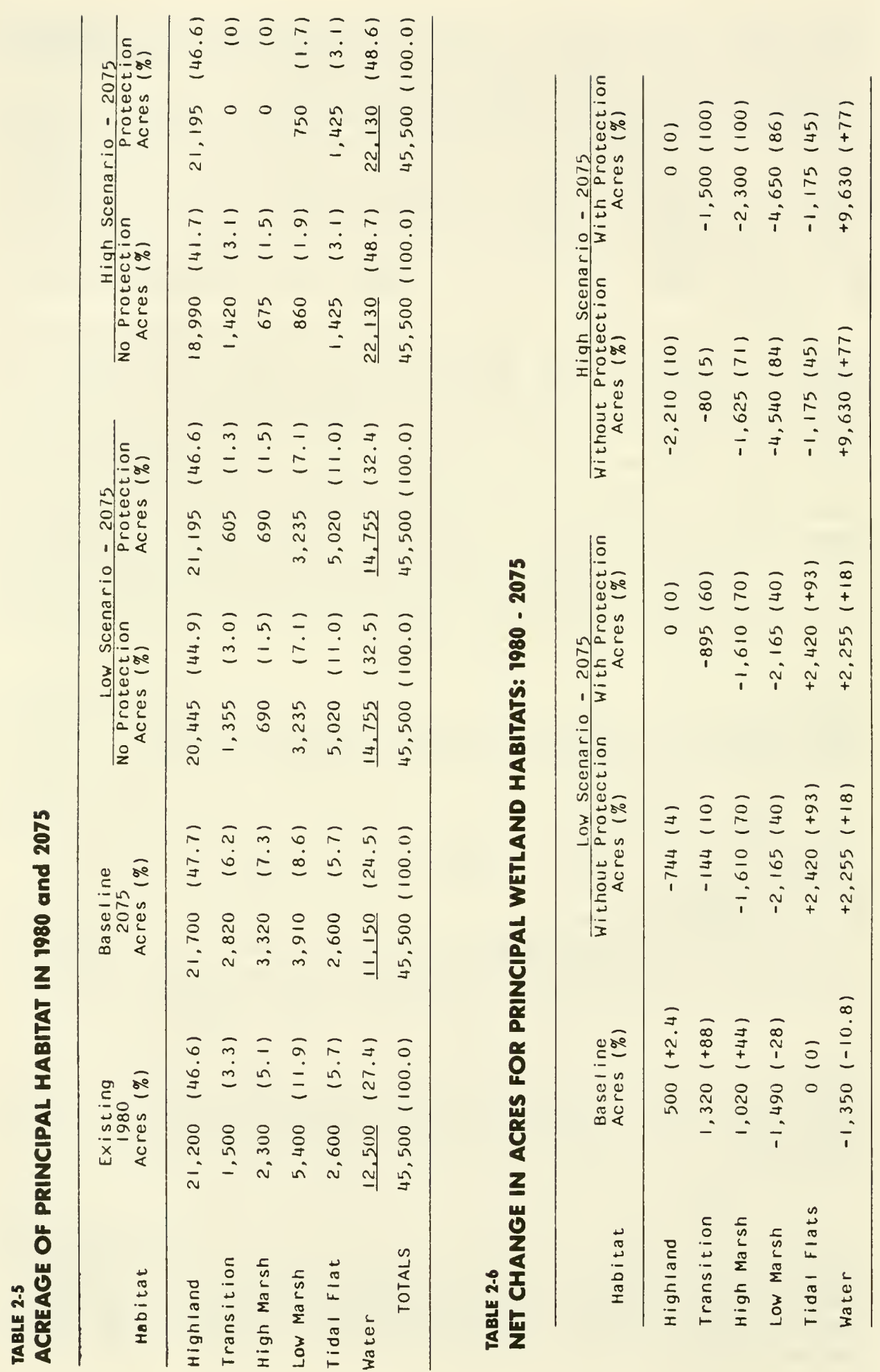


The net change in areas under the various scenarios listed in Table 2-6 indicates that all habitats would undergo significant alteration. Even under the baseline scenario, which assumes historical rates of sea level rise, 20-35 percent losses of representative marsh areas are expected by 2075. Protection under the low scenario (as outlined by Gibbs 1984) would have virtually no effect on high or low marsh coverage; but it would cause a substantially increased loss of transition wetlands. Under the high scenario with protection, highland would be saved at the expense of all transition and high marsh areas and almost 90 percent of the low marsh. Even under the low scenario, sea level rise would become the dominant cause of wetland loss in the Charleston area.

\section{RECOMMENDATIONS FOR FURTHER STUDY}

This study is a first attempt at determining the potential impact of accelerated sea level rise on wetlands; there remains a need for case studies of other estuaries. Louisiana provides a present-day analog for the effect of rapid sea level rise on wetlands because of high subsidence rates along the Mississippi Delta (see Gagliano 1984). Additional studies in that part of the coast should attempt to document the temporal rate of transformation from marsh to submerged wetlands.

Accurate wetland transects with controlled elevations are required to determine the preferred substrate elevations for predominant wetland species. With better criteria for elevation and vegetation, we can use remote-sensing techniques and aerial photography to delineate wetland contours on the basis of vegetation. Scenario modeling can then proceed using computer-enhanced images of wetlands and surrounding areas, for more accurate delineation of marsh habitats. Using historical aerial photos, it may also be possible to infer sedimentation rates by changes in plant coverage or species type, which could be related to elevation using some of the criteria provided in this report.

Another problem that remains with this type of study is the frame of reference for mean sea level. For practical reasons, mean sea level for a standard period (18.6 years generally) cannot be computed until after the period ends. Therefore, fixed references, such as the NGVD of 1929, are used. But sea level in Charleston has an elevation of about $15 \mathrm{~cm}$ (NGVD). If everyone uses the same reference plane for present and future conditions, the problem may be minor. But it does not allow us to determine modal elevations with respect to today's sea level. The transects surveyed for the present study suggest that $S$. alterniflora (low marsh) grows optimally at an elevation of $75 \mathrm{~cm}(2.45 \mathrm{ft}$ ) above mean sea level, close to mean high water (U.S. Department of Commerce 1981). Compared with today's mean sea level in Charleston, S. alterniflora probably tends to grow as much as $15 \mathrm{~cm}$ below actual mean high water, which may confuse the reader who forgets that the NGVD is $15 \mathrm{~cm}$ below today's sea level.

The basic criteria for delineating elevations of various wetland habitats in this study can be easily tested in other areas. By applying normalized flood probabilities (similar to those depicted in Figure 2-7), it will be possible to measure marsh transects in other tide-range areas and relate them to the results for Charleston.

\section{Normalized Elevations}

The absolute modal elevation for each species is site-specific for Charleston. Presuming that the zonation is controlled primarily by tidal inundation, it is possible to normalize the data for other tide ranges based on frequency curves for each water level. Figure 2-7 contains two such "tide probability" curves, based on detailed statistics of Atlantic Coast water levels given in Ebersole (1982) and summarized in Appendix 2-A. The graph of Figure 2-7A gives the probability of various water levels for Charleston. In Figure 2-7B, the data have been normalized 
for the mean tide range of $156 \mathrm{~cm}(5.2 \mathrm{ft})$ in Charleston and given as a cumulative probability distribution. These graphs are applicable to much of the southeastern U.S. coast by substituting different tide ranges. Each graph provides a measure of the duration of time over the year that various wetland elevations are underwater.

In the case of Salicomia virginica $(+3.16 \mathrm{ft}$ for Charleston), the cumulative frequency of flooding is approximately 4 percent (Figure 2-7B and Appendix 2-A). If one wanted to apply

\section{FIGURE 2-7}

\section{TIDE PROBABILITY CURVES}
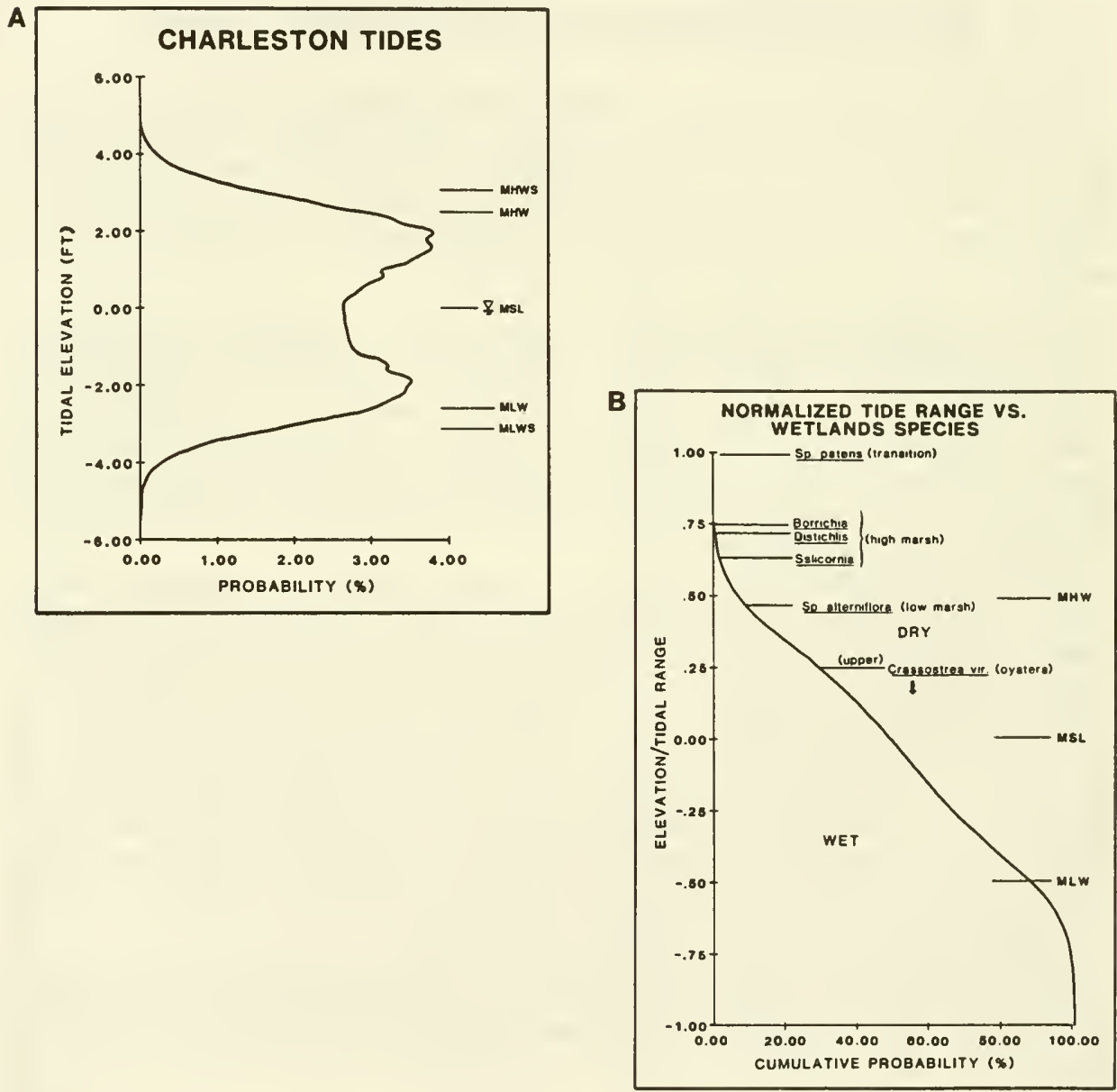

Tide-probability curves based on statistics for Charleston given in Ebersole (1982).

(A) Probability distribution for the range of astronomic tides.

(B) "Normalized" cumulative probability distribution, indicating the preferential elevation for various wetland species.

Abbreviations: MHWS (mean high water spring); MHW (mean high water); MSL (mean sea level); MLW (mean low water); MLWS (mean low water spring). 
these results for an area with a different tide range but similar species occurrence, such as Sapelo Island (Georgia), the flooding frequency for $S$. virginica could be used to estimate its modal elevation at the locality. With a mean tide range of $8.5 \mathrm{ft}$ at Sapelo, $\mathrm{S}$. virginica is likely to occur around $+5.3 \mathrm{ft} \mathrm{MSL}$ (based on substitution of the tide range in Figure 2-7B). This procedure can be applied for other southeastern U.S. marshes as a preliminary estimate of local modal elevations.

We do not consider elevation results for the transects to be definitive because of the relatively small sample size. However, the results are sufficiently indicative of actual trends to allow scenario modeling. With the tide-probability curves presented, it should be possible to check these results against other areas with similar climatic patterns, but different tide ranges.

\section{CONCLUSIONS}

Our results appear to confirm the hypothesis that there would be less land for wetlands to migrate onto if sea level rises, than the current acreage of wetlands in the Charleston area.

Wetlands in the Charleston area have been able to keep pace with the recent historical rise in sea level of one foot per century. However, a three- to five-foot rise in the next century resulting from the greenhouse effect would almost certainly exceed their ability to keep pace, and thus result in a net loss of wetland acreage.

The success with which coastal wetlands adjust to rising sea level in the future will depend upon whether human activities prevent new marsh from forming as inland areas are flooded. If human activities do not interfere, a three-foot rise in sea level would result in a net loss of about 50 percent of the marsh in the Charleston area. A five-foot rise would result in an 80 percent loss.

To the extent that levees, seawalls, and bulkheads are built to prevent areas from being flooded as the sea rises, the formation of new marsh will be prevented. We estimate that 90 percent of the marsh in Charleston-including all of the high marsh-would be destroyed if sea level rises five feet and walls are built to protect existing development.

This study represents only a preliminary investigation into an area that requires substantial additional research. The methods developed here can be applied to estimate marsh loss in similar areas with different tidal ranges without major additional field work. Nevertheless, more field surveys and analysis will be necessary to estimate probable impacts of future sea level rise on other types of wetlands.

The assumptions used to predict future sea level rise and the resulting impacts on wetland loss must be refined considerably so that one can have more confidence in any policy responses that are based on these predictions. The substantial environmental and economic resources that can be saved if better predictions become available soon will easily justify the cost (though substantial) of developing them (Titus et al. 1984). However, deferring policy planning until all remaining uncertainties are resolved is unwise.

The knowledge that has accumulated in the last twenty-five years has provided a solid foundation for expecting sea level to rise in the future. Nevertheless, most environmental policies assume that wetland ecosystems are static. Incorporating into environmental research the notion that ecosystems are dynamic need not wait until the day when we can accurately predict the magnitude of the future changes. 
${ }^{1}$ These scenarios were originally used by Kana et al. (1984). They are based on local subsidence and the Hoffman et al. (1983) mid-low and mid-high scenarios. See Titus et al. (1984) for further explanation.

${ }^{2}$ Plots of the profile of each transect, showing the modal elevations of the substrate and zonation of plant species, can be found in Appendix A of an earlier publication of this study: T. Kana, B. Baca, M. Williams, 1986, Potential Impacts of Sea Level Rise on Wetlands Around Charleston, North Carolina, U.S. Environmental Protection Agency, Washington, D.C.

${ }^{3}$ Kurz and Wagner (1957) and Stalter (1968) found lower elevation limits for S. altemiflora growth in the Charleston area. However, we found these marshes to be highly variable and often terminated in oyster reef or steep dropoffs which precluded the growth of vegetation. The lack of vegetation in these areas and the inherent variability of area marshes may explain these discrepancies with earlier works.

${ }^{4}$ For budgetary reasons, we could not rigorously calculate areas using a computerized planimeter. This level of precision would be questionable anyway, in light of the imprecision of USGS topographic maps in delineating marshes and tidal flats near mean water levels.

${ }^{5}$ Because the standard error of a sum is less than the sum of individual standard errors, the errors are likely to be less. Unfortunately, we had no way of rigorously testing these results within the time and budget constraints of the project.

${ }^{6}$ The scenario referred to as "medium" in Barth and Titus is called "high" in this report.

\section{REFERENCES}

Barth, M.C., and J.G. Titus (Eds.), 1984. Greenhouse Effect and Sea Level Rise. Van Nostrand Reinhold Co., New York, N.Y., 325 pp.

Boesch, D.F., D. Levin, D. Nummedal, and K. Bowles, 1983. Subsidence in Coastal Louisiana: Cases, Rates and Effects on Wetlands. U.S. Fish and Wildlife Serv., Washington, D.C., FWS/OBS-83/26, 30 pp.

DeLaune, R.D., C.J. Smith, and W.H. Patrick, Jr., 1983. "Relationship of marsh elevation, redox potential, and sulfide to Spartina altemiflora productivity." Soil Science Amer. Jour., Vol. 47, pp. 930-935.

Duc, A.W., 1981. "Back barrier stratigraphy of Kiawah Island, South Carolina." Ph.D. Dissertation, Geol. Dept., University of South Carolina, Columbia, 253 pp.

Ebersole, B.A., 1982. Atlantic Coast Water-level Climate. WES Rept. 7, U.S. Army Corps of Engineers, Waterways Experiment Station, Vicksburg, Miss., 498 pp.

Gagliano, S.M., 1984. Independent reviews (comments of Sherwood Gagliano). In M.C. Barth and J.G. Titus (Eds.), Greenhouse Effect and Sea Level Rise. Van Nostrand Reinhold Co., New York, N.Y., Chap. 10, pp. 296-300.

Gagliano, S.M., K.J. Meyer Arendt, and K.M. Wicker, 1981. "Land loss in the Mississippi deltaic plain." In Trans. 31st Ann. Mtg., Gulf Coast Assoc. Geol. Soc. (GCAGS), Corpus Christi, Texas, pp. 293-300.

Gallagher, J.L., R.J. Reimold, and D.E. Thompson, 1972. "Remote sensing and salt marsh productivity." In Proc. 38th Ann. Mtg. Amer. Soc. Photogrammetry. Washington, D.C., pp. $477-488$.

Gibbs, M.J., 1984. "Economic analysis of sea level rise: methods and results." In M.C. Barth and J.G. Titus (Eds.), Greenhouse Effect and Sea Level Rise. Van Nostrand Reinhold Co., New York, N.Y., Chap. 7, pp. 215-251. 
Hatton, R.S., R.D. DeLaune, and W.H. Patrick, 1983. "Sedimentation, accretion and subsidence in marshes of Barataria Basin, Louisiana." Limnol. and Oceanogr., Vol. 28, pp. 494-502.

Hayes, M.O., and T.W. Kana (Eds.), 1976. Terrigenous Clastic Depositional Environments, Tech. Rept. NO. 11-CRD. Coastal Research Division, Dept. Geol., Univ. South Carolina, 306 pp.

Hicks, S.D., H.A. DeBaugh, and L.E. Hickman, 1983. Sea Level Variations for the United States 1855-1980. National Ocean Service, U.S. Department of Commerce, Rockville, Maryland.

Kana, T.W., J. Michel, M.O. Hayes, and J.R. Jensen, 1984. "The physical impact of sea level rise in the area of Charleston, South Carolina. In M.C. Barth and J.G. Titus (Eds.), Greenhouse Effect and Sea Level Rise. Van Nostrand Reinhold Co., New York, N.Y., Chap. 4, pp. 105-150.

Kana, T.W., B.J. Baca, M.L. Williams, 1986. Potential Impacts of Sea Level Rise on Wetlands Around Charleston, South Carolina. U.S. EPA, Washington, D.C., 62 pp.

Kurz, H., and K. Wagner. 1957. Tidal Marshes of the Gulf and Atlantic Coasts of Northern Florida and Charleston, South Carolina. Florida State Univ. Stud. 24, 168 pp.

Nixon, S.W., 1982. The Ecology of New England High Salt Marshes: A Community Profile. U.S. Fish and Wildlife Serv., Washington, D.C., FWS/OBS-81/55, 70 pp.

Nummedal, D., 1982. "Future sea level changes along the Louisiana coast." In D.F. Boesch (Ed.), Proc. Conf. Coastal Erosion and Wetland Modfification in Louisiana: Causes, Consequences and Options. U.S. Fish and Wildlife Serv., Washington, D.C., FWS/OBS-82/59, pp. 164-176.

Odum, E.P., and M.E. Fanning, 1973. "Comparisons of the productivity of Spartina altemiflora and Spartina cynosuroides in Georgia coastal marshes." Bull. Georgia Acad. Sci., Vol. 31, pp. 1-12.

Pendleton, E.C., 1984. Personal communication. U.S. Fish and Wildlife Serv., National Coastal Ecosystems Team, Slidell, LA.

Redfield, A.C., 1972. "Development of a New England salt marsh." Ecol. Monogr., Vol. 42, pp. 201-237.

Schubel, J.R., 1972. "The physical and chemical conditions of the Chesapeake Bay." Jour. Wash. Acad. Sci., Vol. 62(2), pp. 56-87.

Scott, G.I., L.C. Thebeau, and T.W. Kana, 1981. "Ashley River marsh survey - Phase I." Prepared for Olde Charleston Partners; RPI, Columbia, S.C., 43 pp.

South Carolina Coastal Council, 1985. Performance Report of the South Carolina Coastal Management Program. South Carolina Coastal Council, Columbia, South Carolina.

Stalter, R. 1968. "An ecological study of a South Carolina salt marsh." Ph.D. Dissertation. Univ. South Carolina, Columbia, $62 \mathrm{pp}$.

Teal, J.M., 1958. "Energy flow in the salt marsh ecosystem." In Proc. Salt Marsh Conf., Mar. Inst., Univ. Georgia, pp. 101-107.

Titus, J.G., T.R. Henderson, and J.M. Teal, 1984. "Sea level rise and wetlands loss in the United States. National Wetlands Newsletter, Environmental Law Inst., Washington, D.C., Vol. 6(5).

Titus, J.G., "Sea Level Rise and Wetlands Loss." In O.T. Magoon (ed.) Coastal Zone '85. American Society of Civil Engineers, New York, New York, pp. 1979-1990.

Titus, J.G., M.C. Barth, M.J. Gibbs, J.S. Hoffman, and M. Kenney, 1984. "An overview of the causes and effects of sea level rise." In M.C. Barth and J.G. Titus (Eds.), Greenhouse Effect and Sea Level Rise. Van Nostrand Reinhold Co., New York, N.Y., Chap. 1, pp. 1-56.

Turner, R.E., 1976. "Geographic variations in salt marsh macrophyle production: a review." Contributions in Marine Science, Vol. 10, pp. 47-48.

U.S. Department of Commerce, 1979. State of South Carolina Coastal Zone Management Program and Final Environmental Impact Statement. Office of Coastal Zone Management, National Oceanic and Atmospheric Administration, Washington, D.C. 
U.S. Department of Commerce, 1981. "Tide tables, east coast of North and South America." NOAA, National Ocean Survey, Rockville, MD., 288 pp.

Valiela, I., J.M. Teal, and W.G. Deuser, 1978. "The nature of growth forms in the salt marsh grass Spartina altemiflora." American Naturalist, Vol. 112(985), pp. 461-470.

Ward, L.G., and D.D. Domeracki, 1978. "The stratigraphic significance of back-barrier tidal channel migration." Geol. Soc. Amer., Abs. with Programs, Vol. 10(4), p. 201.

Wilson, K.A., 1962. North Carolina Wetlands: Their Distribution and Management. North Carolina Wildlife Resources Commission, Raleigh, N.C.

\section{APPENDIX 2-A}

\section{TIDE ELEVATION PROBABILITY DISTRIBUTION FOR CHARLESTON, SOUTH CAROLINA}

(Based on data given by Ebersole, 1982)

\begin{tabular}{|c|c|c|c|c|}
\hline $\begin{array}{c}\text { Common } \\
\text { Reference* }\end{array}$ & $\begin{array}{l}\text { Elevation } \\
\text { (ft, MSL) }\end{array}$ & $\begin{array}{c}\text { Normalized Elev. } \\
\text { (Elevation/ } \\
\text { Tidal Range) }\end{array}$ & $\begin{array}{c}\text { Probability } \\
(\%)\end{array}$ & $\begin{array}{c}\text { Cumulative } \\
\text { Probability } \\
(\%)\end{array}$ \\
\hline & 5.2 & 1.000 & 0.00 & 0.00 \\
\hline & 5.0 & 0.962 & 0.01 & 0.01 \\
\hline & 4.8 & 0.923 & 0.02 & 0.03 \\
\hline & 4.6 & 0.885 & 0.03 & 0.06 \\
\hline & 4.4 & 0.846 & 0.08 & 0.14 \\
\hline & 4.2 & 0.808 & 0.13 & 0.27 \\
\hline & 4.0 & 0.769 & 0.26 & 0.53 \\
\hline & 3.8 & 0.731 & 0.44 & 0.97 \\
\hline & 3.6 & 0.692 & 0.72 & 1.69 \\
\hline & 3.4 & 0.654 & 1.01 & 2.70 \\
\hline \multirow[t]{3}{*}{ MHWS } & 3.2 & 0.615 & 1.54 & 4.24 \\
\hline & 3.0 & 0.577 & 2.02 & 6.26 \\
\hline & 2.8 & 0.538 & 2.55 & 8.81 \\
\hline \multirow[t]{9}{*}{ MHW } & 2.6 & 0.500 & 2.97 & 11.78 \\
\hline & 2.4 & 0.462 & 3.20 & 14.98 \\
\hline & 2.2 & 0.423 & 3.40 & 18.38 \\
\hline & 2.0 & 0.385 & 3.47 & 21.85 \\
\hline & 1.8 & 0.346 & 3.48 & 25.33 \\
\hline & 1.6 & 0.308 & 3.22 & 28.55 \\
\hline & 1.4 & 0.269 & 3.18 & 31.73 \\
\hline & 1.2 & 0.231 & 2.89 & 34.62 \\
\hline & 1.0 & 0.192 & 2.76 & 37.38 \\
\hline
\end{tabular}




\begin{tabular}{|c|c|c|c|c|}
\hline $\begin{array}{c}\text { Common } \\
\text { Reference* }\end{array}$ & $\begin{array}{l}\text { Elevation } \\
\text { (ft, MSL) }\end{array}$ & $\begin{array}{c}\text { Normalized Elev. } \\
\text { (Elevation/ } \\
\text { Tidal Range) }\end{array}$ & $\begin{array}{c}\text { Probability } \\
(\%)\end{array}$ & $\begin{array}{c}\text { Cumulative } \\
\text { Probability } \\
(\%)\end{array}$ \\
\hline & 0.8 & 0.154 & 2.71 & 40.09 \\
\hline & 0.6 & 0.115 & 2.69 & 42.78 \\
\hline & 0.4 & 0.077 & 2.66 & 45.44 \\
\hline & 0.2 & 0.038 & 2.65 & 48.09 \\
\hline & 0.0 & 0.000 & 2.66 & 50.75 \\
\hline & -0.2 & -0.038 & 2.67 & 53.42 \\
\hline & -0.4 & -0.077 & 2.80 & 56.22 \\
\hline & -0.6 & -0.115 & 2.94 & 59.16 \\
\hline & -0.8 & -0.154 & 3.13 & 62.29 \\
\hline & -1.0 & -0.192 & 3.17 & 65.46 \\
\hline & -1.2 & -0.231 & 3.47 & 68.93 \\
\hline & -1.4 & -0.269 & 3.64 & 72.57 \\
\hline & -1.6 & -0.308 & 3.78 & 76.35 \\
\hline & -1.8 & -0.346 & 3.72 & 80.07 \\
\hline & -2.0 & -0.385 & 3.77 & 83.84 \\
\hline & -2.2 & -0.423 & 3.39 & 87.23 \\
\hline & -2.4 & -0.462 & 3.14 & 90.37 \\
\hline \multirow[t]{3}{*}{ MLW } & -2.6 & -0.500 & 2.54 & 92.91 \\
\hline & -2.8 & -0.538 & 2.13 & 95.04 \\
\hline & -3.0 & -0.577 & 1.67 & 96.71 \\
\hline \multirow[t]{11}{*}{ MLWS } & -3.2 & -0.615 & 1.16 & 97.87 \\
\hline & -3.4 & -0.654 & 0.86 & 98.73 \\
\hline & -3.6 & -0.692 & 0.53 & 99.26 \\
\hline & -3.8 & -0.731 & 0.35 & 99.61 \\
\hline & -4.0 & -0.769 & 0.21 & 99.82 \\
\hline & -4.2 & -0.808 & 0.12 & 99.94 \\
\hline & -4.4 & -0.846 & 0.03 & 99.97 \\
\hline & -4.6 & -0.885 & 0.02 & 99.99 \\
\hline & -4.8 & -0.923 & 0.01 & 100.00 \\
\hline & -5.0 & -0.962 & 0.00 & 100.00 \\
\hline & -5.2 & -1.00 & 0.00 & 100.00 \\
\hline
\end{tabular}

"MHW - mean high water

MLW - mean low water

MSL - mean sea level

MHWS - mean high water spring

MLWS - mean low water spring 

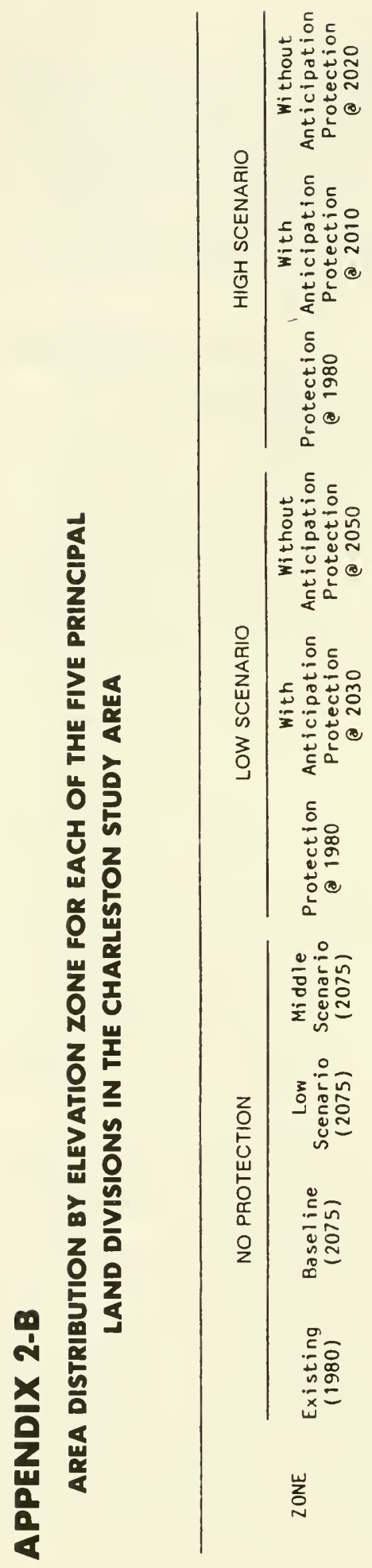

$\mathbb{\Sigma}, 1,1$,

$\mathbb{\Sigma}, 1,1,1$,

$\frac{\pi}{2} \cdot 1,1$

$\Sigma, 1,1$,

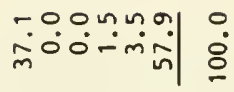

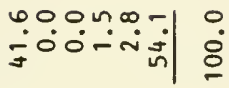

|

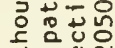

능 중

王뭉

荌市

足 돈

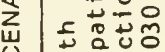

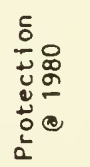

온

r

₹, , 1, ,

0
0
5
5

文, 1, 1

n

茨

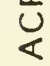

$\stackrel{5}{\leftarrow}$

\& $1,1,1$

II

㟧

$\frac{2}{2} \div \frac{0}{5}$

음 웅

造

z

$\ddot{z} \quad \ddot{m} \because \because \dot{\sigma} \dot{0} \dot{0}$

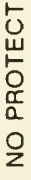
虫

$\therefore \frac{\pi}{n}$

옹

車

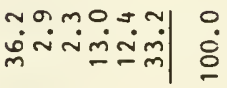

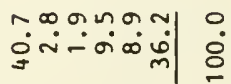

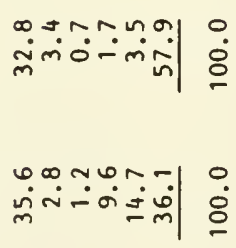

㕰

$\mathbb{z}, 1,1$,

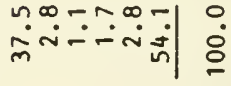

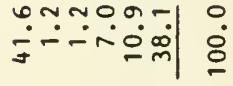

$\frac{0}{2}$
$\frac{1}{n}$
$\frac{1}{z}$
$\frac{1}{0}$

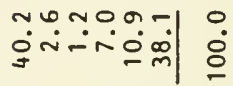

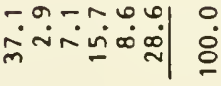

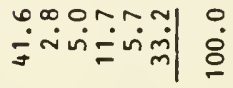

0

岁

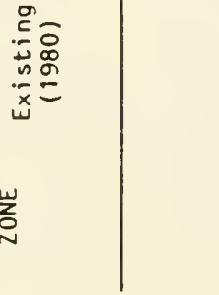

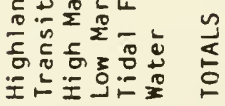

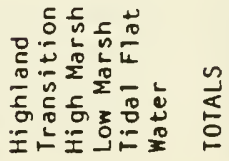




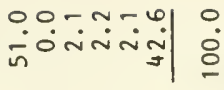

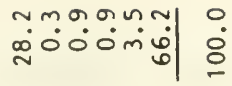

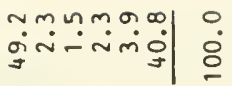

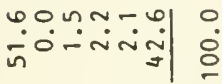

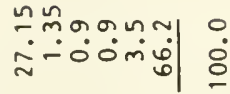

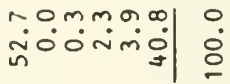

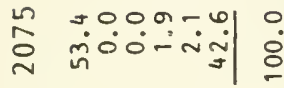

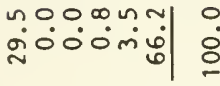

$\because \stackrel{0}{\circ}$

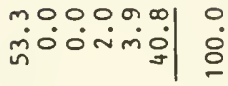

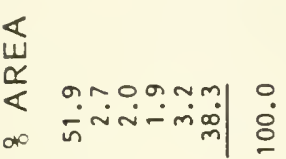

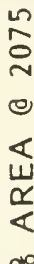

$\frac{a}{0} \quad \frac{1}{\alpha}$

क $<$

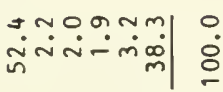

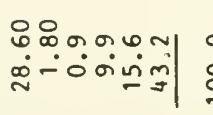

c

0

ᄋ

ก)

น

$\underset{4}{\alpha}$

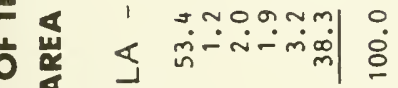

8

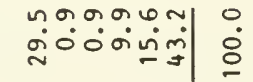

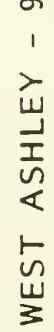

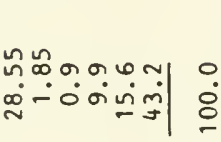

$<$

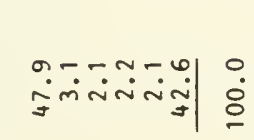

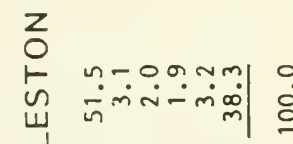

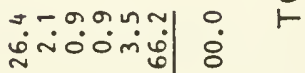

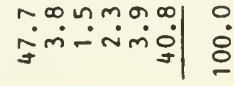

$\ddot{\vdash}$

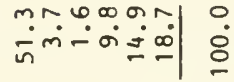

do

in

$n$

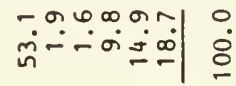

in

$\underset{\alpha}{\alpha}$

ஸ்

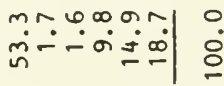

$\frac{1}{<}$

占

$z$

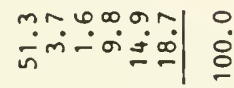

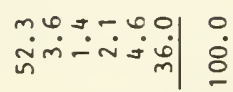

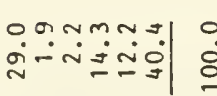

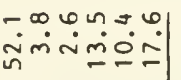

웅

mंm-ñ்

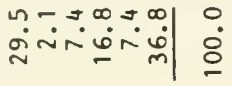

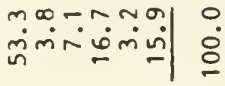

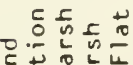

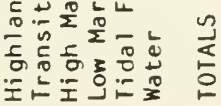

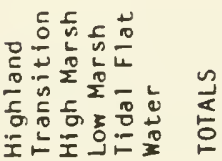

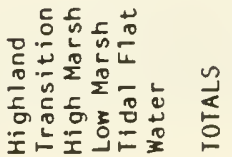





\title{
Chapter 3
}

\section{NEW JERSEY CASE STUDY}

\author{
by \\ Timothy W. Kana, William C. Eiser, \\ Bart J. Baca, and Mark L. Williams \\ Coastal Science \& Engineering, Inc. \\ P.O. Box 8056 \\ Columbia, South Carolina 29202
}

\section{INTRODUCTION}

We applied the same method developed for Charleston to the area around Tuckerton, New Jersey. We gathered data on the vegetation at various elevations within the marsh, and then developed a composite transect representing an average profile of the area. Using this information and estimates of the sediment provided by nearby marshes, we then estimated the shifts in wetland communities and net loss of marsh acreage associated with three possible scenarios of sea level rise for the year 2075: the current sea level trend and worldwide rises in sea level of 66 and 138 centimeters $(\mathrm{cm})(2.2$ and $4.5 \mathrm{ft}$ ) by 2075, which would imply rises of 87 and $159 \mathrm{~cm}(2.9$ and $5.2 \mathrm{ft})$ around South Central New Jersey, allowing for local effects. While emphasizing site-specific data, the results presented in this study provide some interesting contrasts with higher tidal range areas, which should prove useful in studies of other wetlands in microtidal settings.

Numerous researchers have surveyed the distribution of plants and species diversity within intertidal salt marshes throughout the United States (Teal 1958; Wilson 1962; Good 1965; Stroud and Cooper 1968; Reimold et al. 1975; Turner 1976; and Nixon 1982). It was not the intent of this study, or of the Charleston study, to provide a detailed species inventory or a refined model of marsh zonation and primary productivity. Rather, our concern was to develop some applicable relationships between the predominant marsh species and corresponding intertidal elevations. Our field surveys were site-specific for the Tuckerton/Little Egg Harbor area but can be applied generally to other microtidal marsh environments by normalizing absolute elevations for the local tide range.

\section{CHARACTERISTICS OF THE STUDY AREA}

The study area encompasses the town of Tuckerton, Little Egg Harbor Inlet, and Long Beach Island, New Jersey (Figure 3-1). To facilitate our analysis, we chose boundaries to coincide with the U.S. Geological Survey (USGS) topographic map of Tuckerton. The total area covered is 14,000 hectares $(34,700$ acres $)$.

Major elements of the study area are the mainland surrounding Tuckerton (northwest portion of the quadrangle); the barrier lagoons of Great Bay (southwest portion) and Little Egg Harbor (northeast portion); and the barrier spits of Long Beach Island, Little Egg Inlet, Beach Haven Inlet, and the Atlantic Ocean in the southeast portion. 

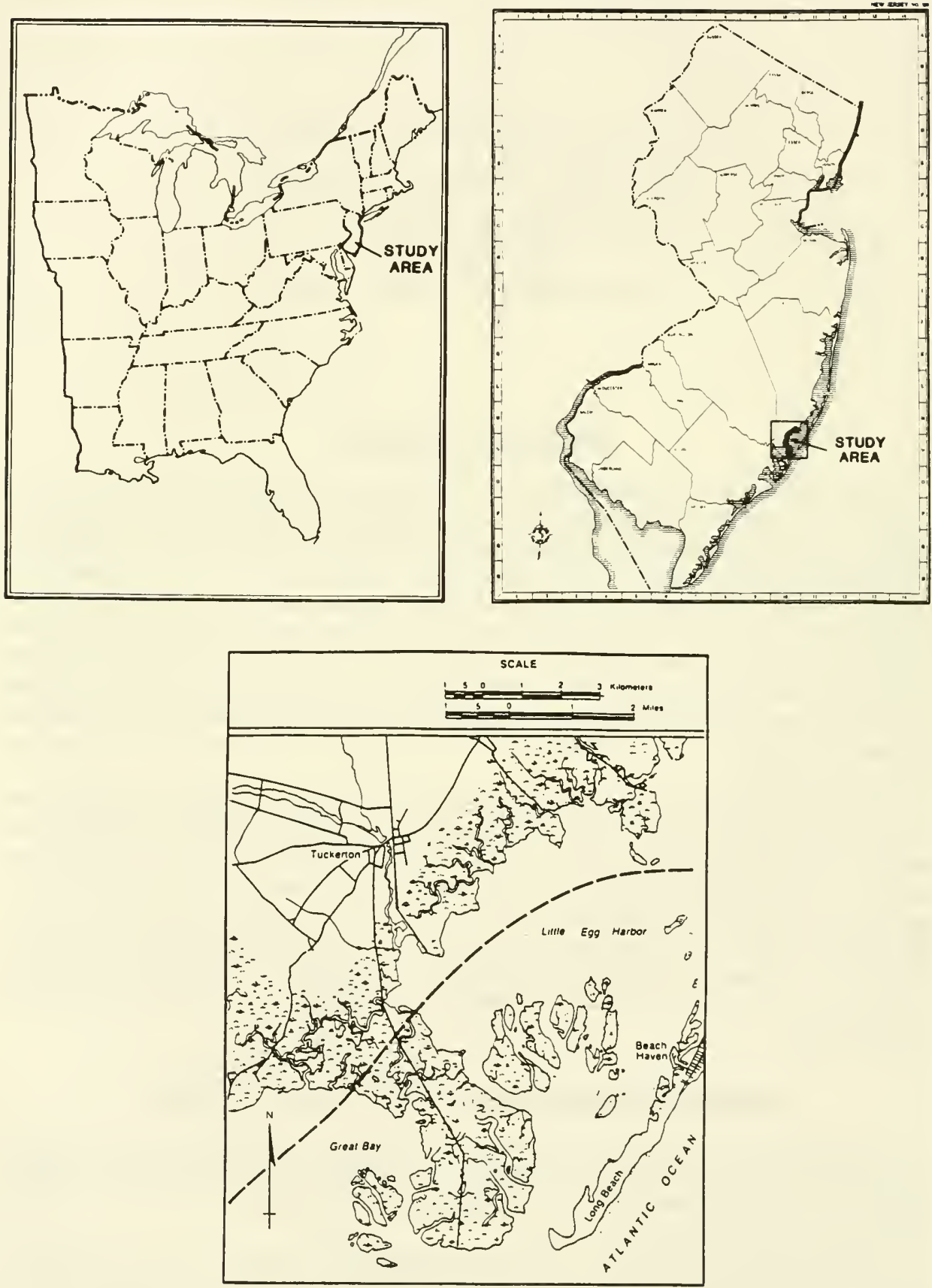


\section{The Inlet and Barrier Lagoon Systems}

Extensive marsh fringes the mainland adjacent to Tuckerton-in some areas, exceeding one mile across. A peninsular marsh, referred to locally as the Great Bay Boulevard marsh, bisects Great Bay and Little Egg Harbor lagoons. Based on its geomorphic configuration, the marsh has most likely formed on part of the flood-tidal delta for the Little Egg and Beach Haven Inlets system. Flood-tidal deltas or landward shoals are common depositional features of microtidal bamier lagoon systems (Hayes and Kana, 1976).

The inlet within the study area is unusual compared to many microtidal inlets because of its large throat width between adjacent barrier beaches. It is locally referred to as two inlets-Beach Haven to the north, which flushes Little Egg Harbor lagoon, and Little Egg Inlet to the south, which flushes Great Bay. However, for all intents and purposes, the two form one system over $3,000 \mathrm{~m}(10,000 \mathrm{ft})$ wide, and there appears to be essentially free exchange of waters between Great Bay and Little Egg Harbor.

Great Bay Boulevard marsh is probably the largest and one of the only untouched marshes in New Jersey. ${ }^{1}$ The marsh adjacent to Tuckerton has been altered by numerous mosquito ditches that crisscross it every 50-100 m (165-330 ft). Long Beach Island, across Little Egg Harbor lagoon, is developed and essentially devoid of fringing marsh, except for the southern tip, which is part of Brigantine National Wildlife Refuge.

\section{Tides and Wetlands}

In contrast to the Charleston, South Carolina, study area, the Tuckerton/Little Egg Harbor area is typical of a microtidal bamier lagoon system. Little Egg Harbor and Great Bay are lagoons enclosed by barier islands that have formed within the past several thousand years after the last deglaciation. Microtidal barrier islands, such as Long Beach Island, are generally separated by widely spaced tidal inlets, which provide the principal flow between the lagoon and the ocean (Hayes 1979). Tidal deltas typicaily form seaward and landward of the inlet as sediments become trapped in low-velocity zones. Of primary interest here is the landward deposit, or "flood-tidal delta," which derives its name from the tidal currents that supply most of the sediment (Hayes 1972). The flood-tidal delta of which Great Bay Boulevard marsh forms a portion is exposed to higher tides because of its proximity to the inlet. Lagoon tidal range drops quickly away from the inlet because of the relatively large volume of water in the basin with respect to the volume that can flow through the inlet over one tidal cycle. Therefore, in microtidal settings, tidal range close to the inlet will almost equal the ocean tidal range but in remote parts of the lagoon, it will be much less.

\section{Tidal Frequencies and Coastal Habitats}

As in the Charleston area, six discrete habitats are found in the Tuckerton study area. They are distinguished by their elevation in relation to sea level and, thus, by how often they are flooded:

- highland - flooded rarely

- transition wetlands - flooding may range from biweekly to annually

- high marshes - flooding may range from daily to biweekly

- low marshes - flooded once or twice daily up to one-half of the time

- tidal flats - flooded about half of the day

- open water - flooded more than half of the day

The distribution of coastal wetlands within the New Jersey study area is balanced for tides occurring twice each day. Because of the lunar cycle and other astronomic or climatic events, 
higher tides than average occur periodically. Spring tides occur approximately fortnightly in conjunction with the new and full moons. The statistical average of these, referred to as mean high water spring (MHWS), has an elevation of $69 \mathrm{~cm}(2.25 \mathrm{ft}$ ) above local mean sea level (MSL) in Little Egg Inlet (U.S. Department of Commerce 1985). Less frequent tidal inundation occurs at even higher elevations at least several times each year.

The frequency of this flooding controls the kinds of plant species that can survive in an area. Unlike the intertidal areas of the southeastern United States, the salt marshes of New Jersey are predominantly high marsh. High marsh has been reported to be over seven times more common than low marsh in the state (Spinner 1969). From the standpoint of primary productivity (organic accumulation per square meter), certain high marshes appear to be as productive as low marshes (Nixon 1982). However, the export of produced organic matter is low from high marsh, indicating its productivity values are less important than those of low marsh.

The marsh wetlands in south-central New Jersey are generally divided into transition zones. The most extensive of these zones occurs between (1) the upland and normal monthly tide level, high marsh, which receives weekly flooding, and (2) the low marsh, which tolerates daily flooding. Near local MSL, prolonged inundation inhibits plant growth and the marsh gives way to intertidal sand and mud flats. The most sheltered areas (with the least wave action) contain the muddiest sediments (Hayes and Kana 1976). The upper limit of salt-tolerant plants appears to be at about the $5.0 \mathrm{ft}$ (about $1.5 \mathrm{~m}$ ) contour shown on USGS topographic maps. This is an important elevation because it represents the lower limit of human development that could occur without altering existing wetlands. The zone below this elevation (delineated on the basis of vegetation types) is a critical area, subject to strict Coastal Zone Management laws of New Jersey.

The pannes, potholes, and depressions within the marsh are unique habitats and have been investigated in certain East Coast marshes (Redfield 1972). The lack of emergent vegetation has been credited to a lack of favorable sediment characteristics (Redfield 1972). The low circulation, depth, and exposure to temperature or salinity extremes may also be factors preventing marsh colonization of the areas once the topographic features are formed.

Mosquito ditches affect the ecology of the East Coast marshes, although there is inadequate information on how extreme these effects may be (Daiber 1974). In the New Jersey sites, ditches increase the flushing of the high marsh and may be enhancing the growth of certain species. More important, substantial low marsh composed of tall $S$. alterniflora is created along the edges of the ditches. Spoil from the ditches is uncommon, but where it occurs, it provides elevation for the growth of Iva frutescens and other high-marsh transitional species. The depth and sediment characteristics of the ditches limit growth of seagrass or tall $S$. alterniflora.

Roads and house lots also affect local marsh ecology. The raised elevations of the roads increase the abundance of high-marsh transitional species, many of which are the dominant roadside vegetation (e.g., Panicum species and Phragmites communis). The lots are covered with material that prevents marsh growth. Sediments from the sand and gravel also enter the nearby marsh and probably influence vegetative growth.

\section{DATA GATHERING AND ANALYSIS}

Before we could model how the rising seas under the three scenarios would affect the coastal wetlands of south central New Jersey, we needed to determine the types, elevation, and productivity of the plant species currently in the marshes. However, as in the Charleston study, there is little data on the elevation range that contains most of the coastal wetlands in New Jersey. For this reason, we surveyed a series of sixteen field transects across representative marshes and tidal flats near Tuckerton. 


\section{Data Collection and Analysis}

Each transect was a sample cross section of an area of the marsh. It began at a benchmark located on high ground near a marsh's boundary, and ended at a tidal creek or mud flat, or after covering $300 \mathrm{~m}(1,000 \mathrm{ft})$-whichever came first. The New Jersey Department of Environmental Protection provided three benchmarks. One was Station E55, located within the mainland near the fringing marsh northeast of Tuckerton, where the mean tidal range is $61 \mathrm{~cm} \mathrm{(2.0} \mathrm{ft).} \mathrm{As}$ Figure 3-2 shows, transects T9-T16 were suneyed there. The other two benchmarks were Stations M55 and P55, located along the Great Bay Boulevard marsh, where the mean tidal range is $96.9 \mathrm{~cm}$ (3.18 ft). These benchmarks were used for transects T1-T8.

The dashed line in Figure 3-2 shows how we arbitrarily subdivided the study area into these two primary survey areas to account for the significant variations in tidal range. The indicated subdivision is not exact, since a continuum exists, but it was necessary for scenario modeling, which is described later in the report. These two ranges represent the typical excursion of water levels between mean high water and mean low water. Since they are statistical averages, they can be related to local mean sea level by definition. In other words, mean high water at the Great Bay Boulevard marsh would be $48.5 \mathrm{~cm}$ (1.59 ft) above local mean sea level, while mean low water would be $48.5 \mathrm{~cm}$ below it. Similarly, in the Tuckerton marsh, mean high water would average 31 $\mathrm{cm}(1.0 \mathrm{ft})$ above local mean sea level. These tides compare with a mean ocean tidal range of $1.1 \mathrm{~m}$ $(3.7 \mathrm{ft})$ in Little Egg inlet.

Because of the difficulty of wading through very soft muds, we had to limit the length of the transects. Although this biased the sample somewhat, logistics prevented a more rigorous approach. Nevertheless, very detailed information on marsh zonation and boundaries in New Jersey is available on 1:2,400 photo maps prepared by the New Jersey Department of Environmental Protection. We used portions of these maps in our study to estimate areal coverage of each marsh type. Budget limitations prevented us from determining all areas by planimetry, so we substituted representative grid squares.

For each transect, we measured the elevation and distance from the benchmark using a rod and level. Data points were surveyed wherever there was a noticeable break in slope or change in species. Typically, we recorded at least 20 survey points along each transect, with the average distance between points being about $7.5 \mathrm{~m}$ ( $25 \mathrm{ft}$ ). Our field team of three people included a biologist who kept parallel notes with the surveyors on the actual species at and between each survey point. Along each transect we collected and tagged samples of species for laboratory typing and verification, noting such information as the elevation of the boundaries between different species. By measuring the length of the transect that a species covered and dividing it by the transect's total length, we computed percentages for the distribution of each species along a transect.

The demarcation between terrestrial plants and salt-tolerant species can often be abrupt because of a sudden change in slope at that point. Wetland transects commonly consist of a series of low-relief steps between areas of more or less constant elevation, with each step representing the upper or most landward deposit of detritus for a particular tide level. However, we have also observed areas where slopes are almost uniform from highland to tidal flats (Kana, Baca, and Williams 1986).

\section{Results of Individual Transects}

Table 3-1 summarizes the results of the sixteen transects, dividing them between the Tuckerton marsh's $61 \mathrm{~cm}$ (2.0 ft) tidal range and the Great Bay Boulevard marsh's $96.9 \mathrm{~cm}(3.18$ $\mathrm{ft}$ ) range. It presents the principal species observed along each transect, their "modal"-or most common-elevations, the percentage of each transect they covered, and the length of each transect. For example, in transect number 3 , short $S$. altemiflora was found at a modal elevation of $86.9 \mathrm{~cm}(2.85 \mathrm{ft})$ and covered 94 percent of the transect. 


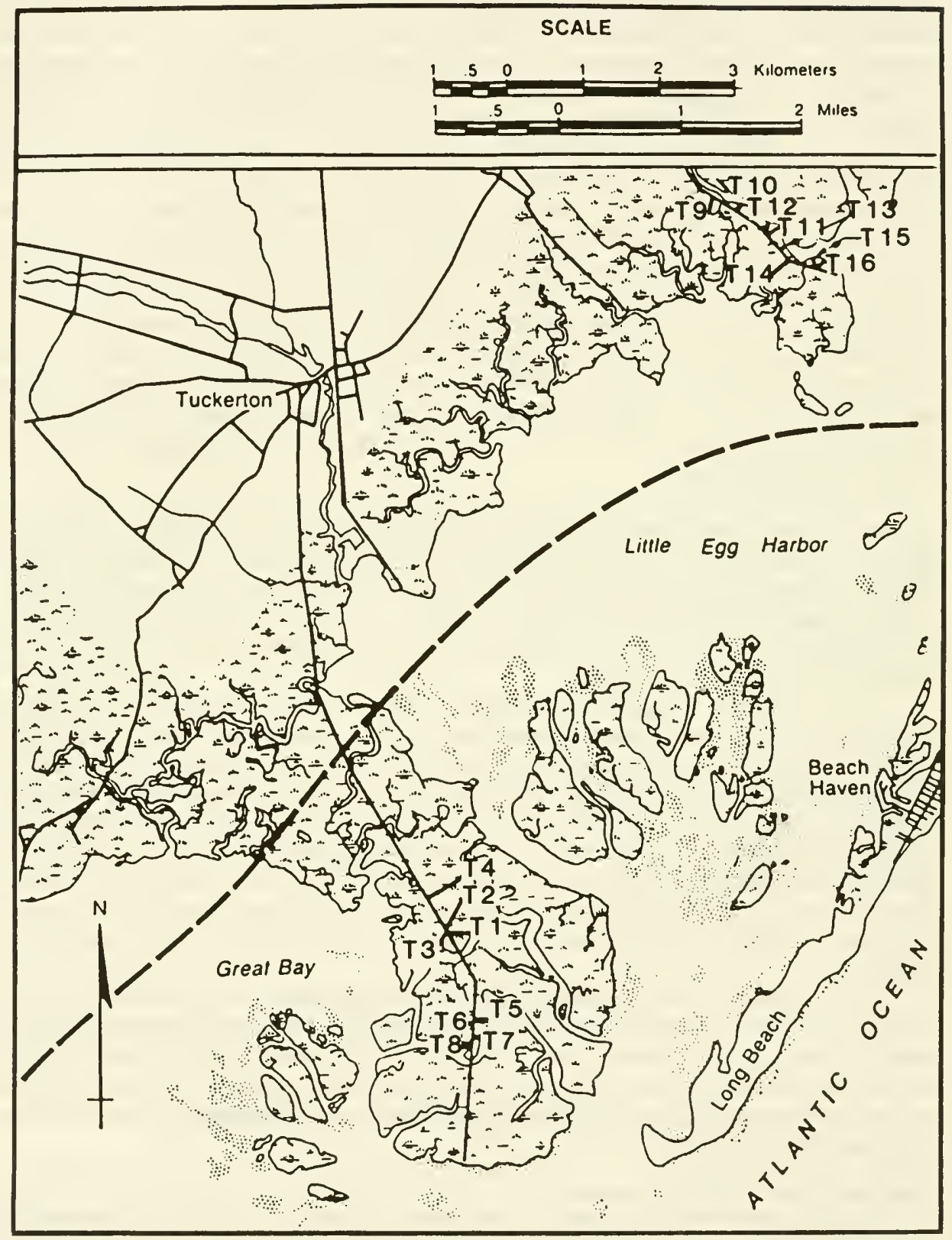

Because species often overlapped, the sums of the percentages exceed 100. In addition, to omit any marginal plants that exist at transition zones, a modal elevation differs slightly from the arithmetic or weighted mean. Appendix 3-A contains histograms of species occurrence. Plots of the profiles of each transect, showing the modal elevations of the substrate and zonation of plant species are available from the authors. 


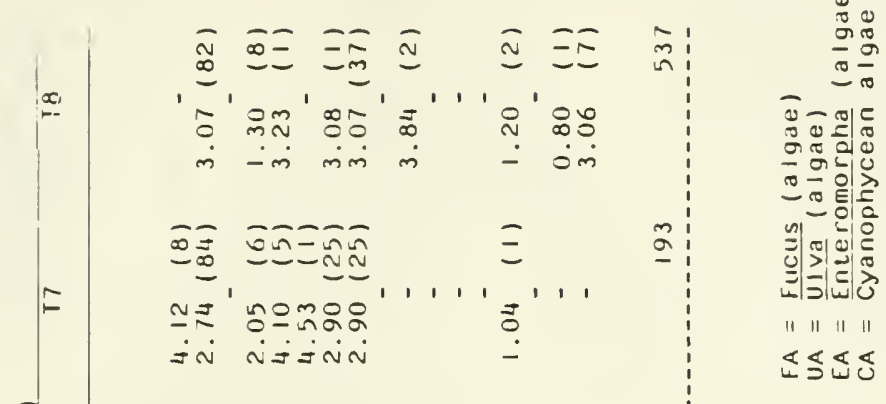

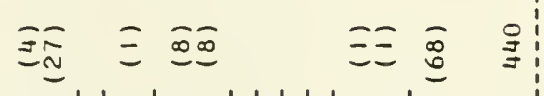

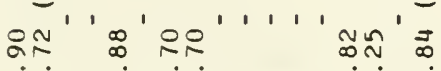

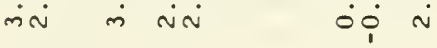

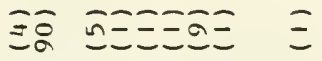

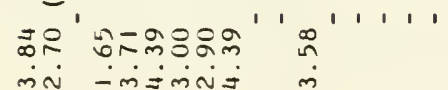
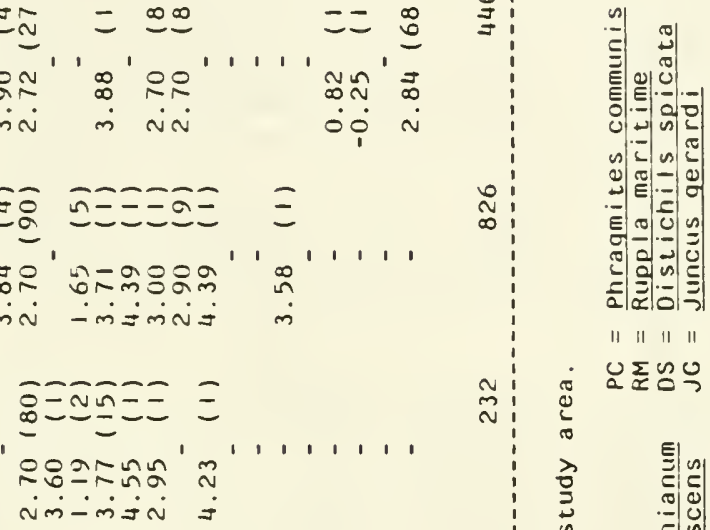

1| $\mid$ || ॥

- $0 \sum^{2} \cong 0$

Ni

马

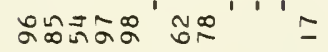

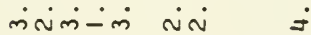

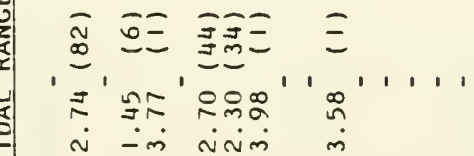

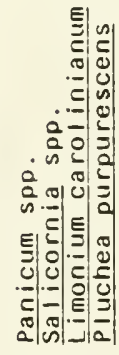

s:

" | |

궁

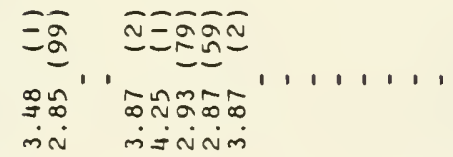




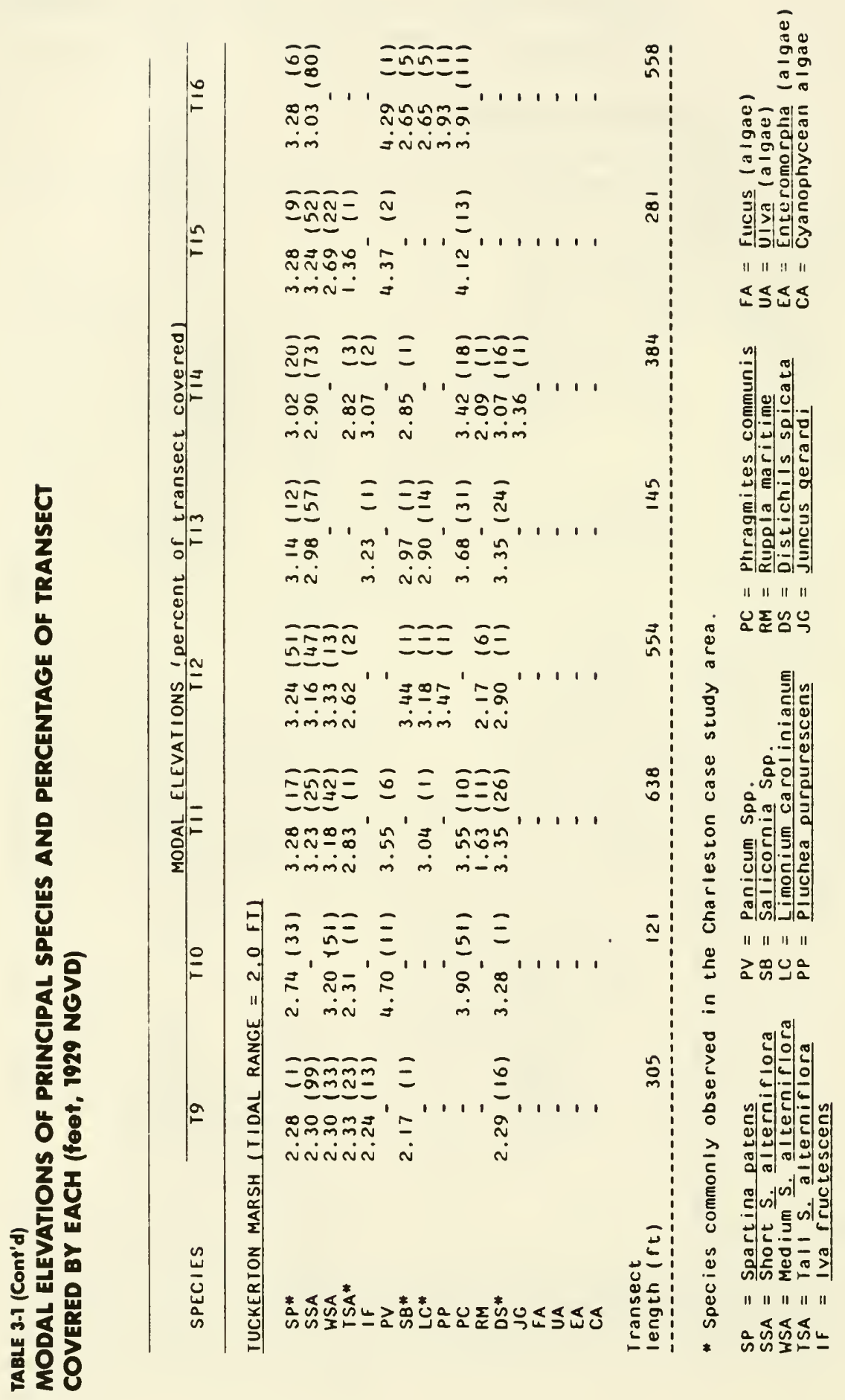




\section{WETLAND TRANSECTS}

The individual components of the New Jersey salt marsh occupy zones consistent with other East Coast areas (reviewed in Nixon 1982). The major zones differentiated in our study are high, low, and transitional marsh. S. altemiflora is frequently dominant in terms of plants per square meter. In transects for this study, the plant occurred in three growth forms: tall, medium, and short. The tall plants occur as the dominant low marsh species, usually as a fringe along the outer periphery of the high marsh. Short $S$. alterniflora is often the dominant plant in the high marsh, and the less common medium S. altermiflora is found in the low marsh, or in high marsh with adequate water circulation. The distinction between medium and short S. alterniflora and other growth sizes is imprecise, but was made in the field to add more insight into zonation.

The dominant high-marsh species in the Tuckerton transects (in decreasing order of abundance) were short S. altermiflora, Spartina patens, medium S. alterniflora, and Distichlis spicata. In the Great Bay Boulevard marsh where tide range is higher, short S. altermiflora was again dominant with Limonium carolinianum and Salicomia spp. next in importance. Although less than $20 \mathrm{~cm}(7.9 \mathrm{in})$ in height, short $S$. altemiflora is a mature plant capable of producing abundant seeds. It was often codominant with $S$. patens, which was at slightly higher elevations. While pure stands of windblown $S$. patens were common, it is decreasing in abundance because of manmade (Gosselink and Baumann 1980) and natural causes (Niering and Warren 1980) and is often being replaced by short S. altemiflora. Distichlis spicata and Salicomia spp. were commonly associated with either high-marsh species-the former more frequently with $S$. patens and the transition zone, and the latter with short $S$. altermiflora. Due to its salinity tolerance, Salicomia spp. was common throughout the study area as well as in shallow pannes where it grew in association with a mat of Cyanophycean algae.

Transitional species occur in zones between high marsh and terrestrial vegetation, between high and low marsh, and between low marsh and water. Panicum spp., Iva frutescens, Pluchea purpurescens, Juncus gerardi, and Phragmites communis occur at the upper limit, or transition zone, of high marsh. The last species is less salt-tolerant and grows at lower elevations only in brackish and freshwater areas. Iva frutescens is a conspicuous plait found wherever adequate elevation exists, whether on the upper high marsh or on elevated areas produced by spoil. No other plant is as common in both elevated situations, and it was also the only woody plant found in the transects. Other plants in the upper high-marsh transition zone were Panicum spp. (usually $P$. amarum and $P$. virgatum). The plants formed belts on the highest elevated marsh areas, frequently as roadside vegetation. Pluchea purpurascens appeared at moderate elevations, frequently with Iva frutescens and Distichlis spicata. Juncus gerardi was uncommon in the transects, usually occurring in the upper zone of high marsh. Phragmites communis was found at the upper elevation of high marsh, frequently along the roadside, when in coastal areas. However, in coastai rivers, it was often dominant in the low marsh, where it formed dense stands.

Cyanophycean algae were the principal submerged plants in the high marsh where they existed as thick mats in pannes and low-lying areas. The seagrass, Ruppia maritima, was common in deeper potholes of the high marsh. The dominant plants at the outer margin of the low marsh were the Chlorophycean alga, Enteromorpha spp. and Ulva spp., and the Phaeophycean alga, Fucus spp. These were submerged at high tide and were attached to rocks and shells.

\section{Composite Transects}

Because of the complexity and varied tidal ranges of the intertidal wetlands in the New Jersey study area, we developed two typical transects to model the scenarios of future sea level rise. The approach we used was similar to the approach used for Charleston (Kana, Baca, and Williams 1986). We used the weighted average percentage of transects covered by each species 
and their modal elevations and then selected the "indicator," or dominant, species for the Tuckerton and Great Bay Boulevard marshes according to the following steps:

1) Interpolate elevations, at $7.5 \mathrm{~m}(25 \mathrm{ft})$ horizontal increments, along each transect.

2) Based on the "distribution of species" graphs (Appendix 3-A) for each transect, determine what species are found, at 25-ft horizontal increments, along each transect.

3) If the total number of occurrences is greater than ten for any given species, construct a frequency histogram for that species. From the histogram, determine the modal elevation for that species.

4) If the total number of occurrences is less than eleven for any species, determine the modal elevation by graphically averaging the transect cross-section.

We prepared frequency histograms for six species and tidal range combinations having a sufficient number of data points (Appendix 3-A). We also computed the mean elevation and corresponding standard deviation for all species. After weighting the "percentage occurrence" or percentage of transects covered by all species, we compiled a summary, or composite list. Table 3-2 gives the results by tidal range for each portion of the study area.

The dominant plant was $S$. alterniflora in both tidal-range zones, with the short variety covering 49-77 percent of the composite transects. Its modal elevation $(86.6-99.1 \mathrm{~cm}$ [2.81-3.25 $\mathrm{ft}$, Table 3-2) in the Tuckerton Marsh was similar to that in the Great Bay Boulevard marsh despite a difference in mean high water of over $15 \mathrm{~cm}(0.5 \mathrm{ft})$. In fact, the mode was reversed for the lower tidal-range marsh, being slightly above the Great Bay Boulevard marsh elevation. One would expect just the opposite, since high-marsh elevation normally increases with tidal range. Since the difference is subtle here, we believe it may be due to the altered drainage of the Tuckerton marsh, which is dissected by numerous ditches. Mosquito-control ditches or similar features increase circulation and may also impound water over the marsh, possibly elevating mean water levels or increasing the duration of flooding. A subtle change such as this could alter flooding frequency and displace marsh habitats upward. Unfortunately, there is no way to confirm this hypothesis for the Tuckerton marsh. However, we believe the difference is real for the present data set.

Second in importance was $S$. patens (23 percent) in the Tuckerton marsh and $L$. carolinianum (23 percent) and Salicomia spp. (20 percent) in the Great Bay Boulevard marsh. S. patens was less common in the Great Bay Boulevard marsh but occurred at significantly higher elevations as we expected: $122 \mathrm{~cm}$ (3.99 ft) versus $92.7 \mathrm{~cm}(3.04 \mathrm{ft})$ in the Tuckerton marsh (Table 3-2). All of these species are indicative of high marsh or the transition above high marsh. While much less common than in South Carolina, tall S. altermiflora nevertheless is an important indicator species of low marsh for New Jersey. We found that it occurred over 4 percent of the composite transect but at higher elevations in the lower tidal range Tuckerton marsh $(+73 \mathrm{~cm}$ [2.4 ft] than in the Great Bay Boulevard marsh $(+48.5 \mathrm{~cm}[1.59 \mathrm{ft}])$. This apparent opposite trend may be related to its occurrence along the banks of mosquito ditches and the possible superelevated mean water levels within the Tuckerton marsh.

Phargmites communis (giant reed) was almost absent in the Great Bay Boulevard marsh but was very common as a fringing species along the Tuckerton marsh. Its modal elevation of $1.15 \mathrm{~cm}$ $(3.78 \mathrm{ft})$ provides a good indicator of the upper limit of yearly tides for the area, since it requires fresh to brackish water.

Figures 3-3 and 3-4 illustrate two hypothetical composite transects for the principal tidal range areas around the Tuckerton and Great Bay Boulevard marshes based on the results in Table 3-2. Each includes elevation divisions, species zonation, and representative tidal levels. The profiles are by no means precise, but they provide an indication of the relationships between each wetland subenvironment. 


$\begin{array}{ccccc} & \text { Modal } & & \text { Number of } & \\ & \text { Elevation* } & & \text { Transects } & \text { Percentage } \\ \text { (ft, 1929 } & \text { Standard } & \text { Observed } & \text { Occurrence } \\ \text { Species } & \text { NGVD) } & \text { Deviation } & >1 \% & \text { Composite }\end{array}$

TUCKERTON MARSH (TIDAL RANGE $=2.0 \mathrm{FT}$ )

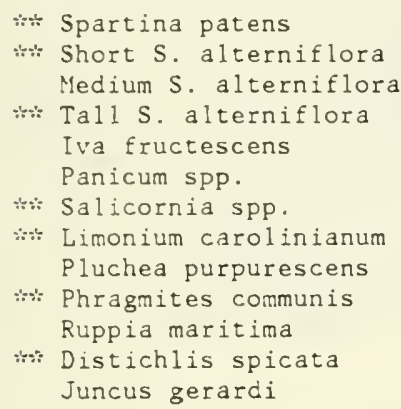

$\begin{array}{ll}3.04 / 3.25 \% & 0.36 / 0.36 \% \\ 2.98 / 3.25 * & 0.27 / 0.33 \% \\ 2.99 / 3.15 \% & 0.37 / 0.35 \% \\ 2.40 & 0.18 \\ 2.75 & 0.31 \\ 4.30 & 0.51 \\ 2.85 & 0.23 \\ 2.83 & 0.12 \\ - & - \\ 3.78 & 0.23 \\ 1.82 & 0.25 \\ 3.09 & 0.38 \\ - & -\end{array}$

$\begin{array}{rr}8 & 23 \\ 7 & 49 \\ 5 & 20 \\ 3 & 4 \\ 2 & 2 \\ 3 & 3 \\ 2 & 2 \\ 2 & 3 \\ 0 & <1 \\ 6 & 17 \\ 2 & 2 \\ 4 & 11 \\ 0 & <1\end{array}$

GREAT BAY BOLLEVARD MARSH (TIDAL RANGE $=3.18 \mathrm{FT}$ )

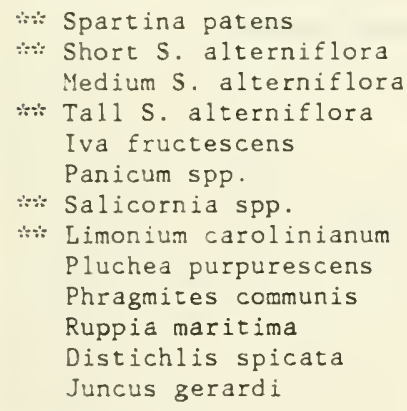

1.59
3.85
$2.89 / 2.95 \%$
$2.83 / 3.00 \%$
3.87
3.84
$=$
$=$

$0.12 / 0.26 *$

- By histogram.

* Recommended indicator, or dominant species.

Note: These results exclude species observed to cover less than 2 percent of a transect.

In comparison to the composite transect for Charleston (Kana, Baca, and Williams 1986) Tuckerton's transects are more terraced, with abrupt changes in slope at transitions between tidal flat, low marsh, and high marsh. The circled elevations in Figures 3-3 and 3-4 are the interpreted upper and lower limits of each subenvironment, based on data from profiles of sixteen transects of the Tuckerton and Great Bay Boulevard marshes. ${ }^{2}$ The transects establish the effective lower

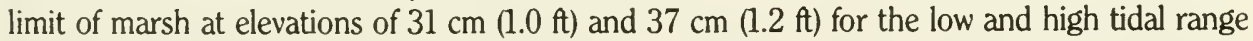
areas, respectively. A major difference between the Tuckerton and the Great Bay Boulevard marshes is the distribution of tidal flats. Tuckerton's fringing marsh has very little, whereas the Great Bay Boulevard marsh is bordered by wide flats representing fully one-third of the wetland areas. 


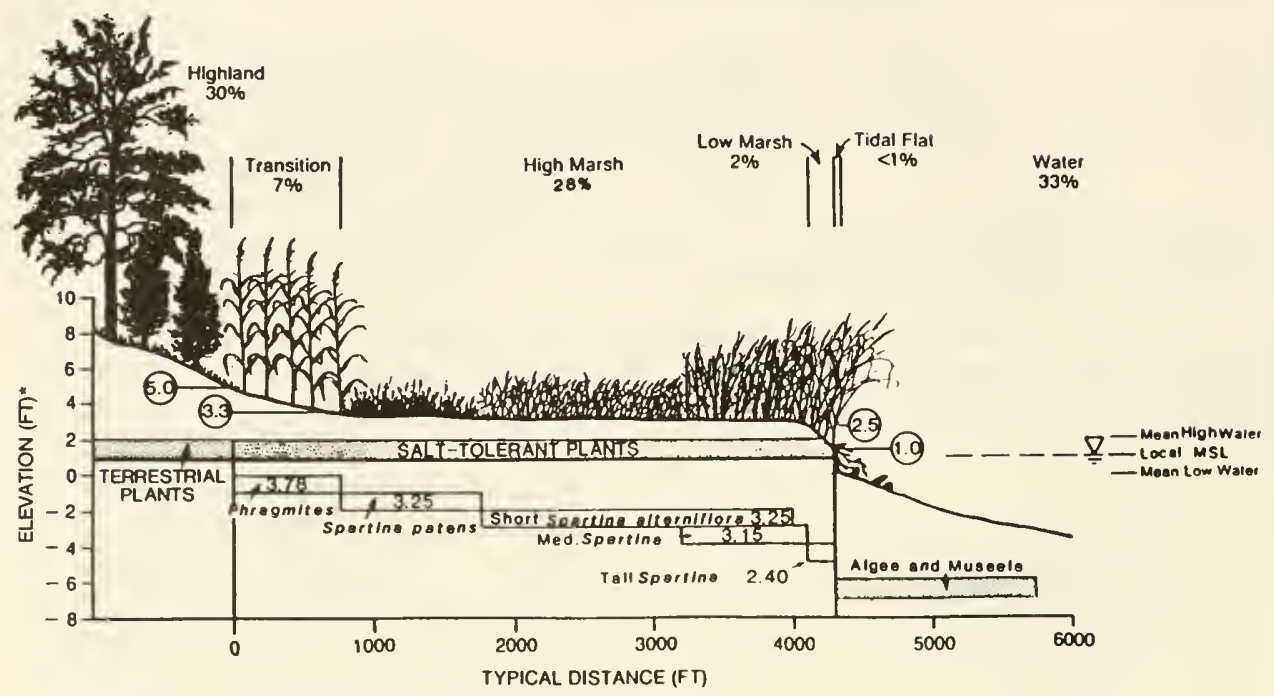

- Elevations are relative to the 1929 NGVD sea level.

\section{FIGURE 3-4}

\section{COMPOSITE TRANSECT OF THE GREAT BAY BOULEVARD MARSH} (Tidal Range $=3.18 \mathrm{ft}$ )

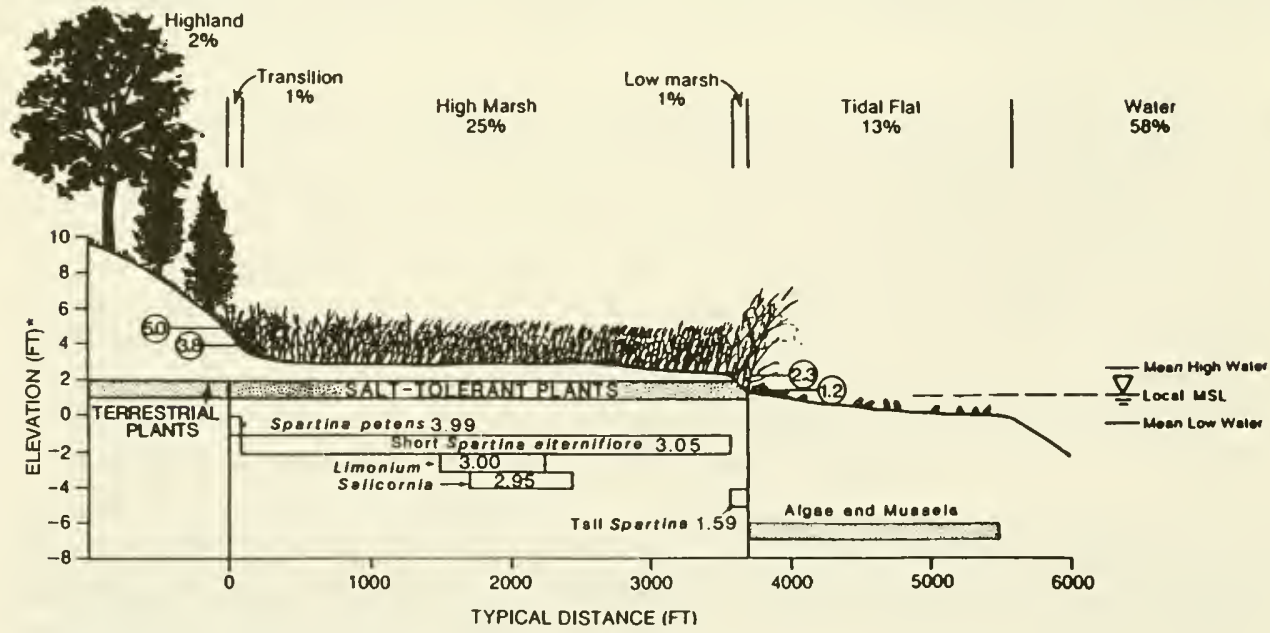

- Elevations are relative to the 1929 NGVD sea level.

The overall zonation given on the composite transects is empirical for central New Jersey and does not presume exact inundation tolerances for each wetland species. A more comprehensive study would be required to establish the elevation ranges and frequency of occurrence of all species-a difficult undertaking, considering the problem of accessing this or any marsh. 


\section{Estimation of Areas}

Two sources of information were available for estimating areas of land, water, and wetlands within the New Jersey study area: (1) USGS 7.5-minute quadrangles and (2) New Jersey Department of Environmental Protection (1:2,400 scale) wetland photo maps with marsh types delineated.

Using the topographic and wetland zonation maps, we estimated the number of acres of each subenvironment for each tide-range zone. For budgetary reasons, it was not possible to analyze the 100 wetland maps that make up the study area. Instead, several of these representative 1:2,400 photo maps were chosen for detailed area checks on the ratio of high marsh to low marsh and tidal flats. These ratios were checked against our surveys to ensure consistency with the composite transects. As in the Charleston case study, the level of precision is limited, but reasonable for scenario modeling. In contrast to Charleston, the New Jersey study area had a more even mix of highland, marsh, and water. In the Tuckerton subdivision, highland, high marsh, and water areas each made up about 30 percent of the area. The next highest area, with 7 percent coverage, was the transition zone. Interestingly, low marsh comprises barely 2 percent of the low tidal-range zone.

With the Great Bay Boulevard subdivision, water, high marsh, and tidal flats dominate in a 4:2:1 ratio, comprising 96 percent of the area. Little highland, transition zone, or low marsh occurs. The total area of the study subdivisions was 16,400 acres (Tuckerton marsh) and 18,300 acres (Great Bay Boulevard marsh), compared with 45,500 acres for the Charleston study area.

\section{SCENARIO MODELING AND RESULTS}

After establishing the basic relationships among elevation, wetland habitats, and species occurrence for Tuckerton/Little Egg Harbor, we developed a conceptual model for changes in marsh under accelerated sea level rise and applied the model to the case study area.

\section{Assumptions Used for Scenario Modeling}

The major assumptions we used for scenario modeling concerned the annual rise in sea level, the average sedimentation rate, and the cutoff elevations for the various subenvironments.

Rise in Sea Level. Based on an earlier study (Barth and Titus 1984), we chose three scenarios of future sea level rise: baseline, low, and high (described in Chapter 1). ${ }^{3}$ To be consistent with the previous study, we projected the scenarios to the year 2075-95 years after the baseline date of 1980 used to determine "present" conditions.

Sedimentation Rate. The model for future wetlands zonation also accounted for sedimentation and peat formation which raise the substrate (absolute elevation) in concert with sea level rise. Sedimentation and peat formation have kept pace with rising relative sea level of $3 \mathrm{~mm}$ (.1 in) per year during the past century over much of the East Coast [e.g., Ward and Domeracki (1978), Duc (1981), Boesch et al. (1983)]. If sea level rises much more rapidly than vertical accretion rates, however, wetland zones will migrate landward.

Weathering rates in the middle Atlantic states are generally lower than the southeastern United States. Nevertheless, after review of the literature on marsh sedimentation, we found no substantial difference between the Charleston and New Jersey study areas. For the Charleston case study, we assumed for modeling purposes an average annual rate of $5 \mathrm{~mm}$ (.2 in) per year based on limited reports by Ward and Domeracki (1978) and summaries by Hatton et al. (1983). Similarly, limited results are available for the New Jersey region. Meyerson (1972) reported a rate of $5.8 \mathrm{~mm}$ (.23 in) per year for a marsh in Cape May, New Jersey. In nearby Delaware, rates of $5.0-6.0 \mathrm{~mm}$ (.20-.24 in) per year were reported by Stearns and MacCreary (1957) in S. altermiflora marsh and by Lord (1980) in short S. altemiflora marsh. Richard (1978) reported rates of 2.0$4.2 \mathrm{~mm}(.08-.17 \mathrm{in})$ per year in a Long Island (New York) S. alterniflora marsh. Although the rate 
of marsh accretion will depend on proximity to tidal channels (sediment sources) and density of plants (baffling effect and detritus), we believe these published rates are reasonably representative for the case study area. Thus, for purposes of modeling, we assumed a sedimentation rate of $5 \mathrm{~mm}(.2 \mathrm{in})$ per year. Obviously, the actual rate will vary across any wetland transect, so this assumed value represents an average. Lacking sufficient quantitative data and considering the broad application of our model, we found it was more feasible to apply a constant rate for the entire study area, even though this assumption may overestimate the rate of vertical accretion in the irregularly flooded transition zone between low marsh and terrestrial highland.

Elevation Zones. Transformation of wetland environments under various sea level rise and sedimentation scenarios also required assumptions regarding existing elevation zonations. The field transects provided criteria for delineating the upper and lower limits of several subenvironments that could be considered as discrete zones for area estimation.

We assumed the cutoff elevation for highland around Tuckerton is $1.5 \mathrm{~m}(5.0 \mathrm{ft})$ NGVD, based on results of the transects and observations in the field. In general, this area is free of yearly flooding and tends to mark the transition from salt-tolerant species to terrestrial vegetation. Although terrestrial vegetation occurs at lower elevations that are impounded between dikes or ridges, this situation is less relevant for sea level rise modeling. The zone of concerm is the area bordering tidal waterways where slopes are assumed to rise continuously without intermediate depressions (see composite transects in Figures 3-3 and 3-4).

The transition zone is defined as a salt-tolerant area between predominant, high-marsh species and terrestrial vegetation. This area is above the limit of fortnightly (spring) tides, but is generally subject to tidal and storm flooding several times each year. The indicator species for this zone were found to be Panicum spp. and Phragmites communis in the low-tidal-range Tuckerton marsh and S. patens and Iva frutescens in the Great Bay Boulevard marsh.

High marsh is defined for the study areas by variable elevation ranges of 70 to $120 \mathrm{~cm}$

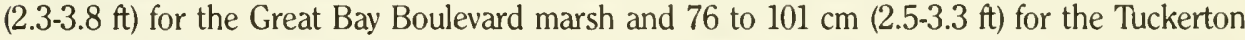
marsh, based on the transects. Dominant species include short $S$. alterniflora at $93.0 \mathrm{~cm}$ (3.05 ft), Limonium carolinianum at $92 \mathrm{~cm}(3.0 \mathrm{ft})$, and Salicomia spp. at $89.9 \mathrm{~cm}(2.95 \mathrm{ft})$ for

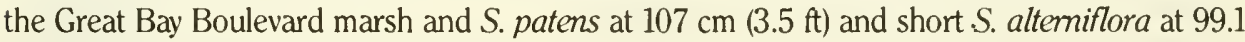
$\mathrm{cm}(3.25 \mathrm{ft})$ for the Tuckerton marsh.

Low marsh ranges from +31 to $+76 \mathrm{~cm}(1.0$ to $2.5 \mathrm{ft})$ based on results of the transects, with a narrower range of elevations (37 to $70 \mathrm{~cm}[1.2-2.3 \mathrm{ft}]$ ) in the higher tidal-range Great Bay Boulevard marsh. The principal indicator species, tall $S$. alterniflora, occurred at 48.5 and $73.2 \mathrm{~cm}$ (1.59 and $2.40 \mathrm{ft}$ ), respectively, in the Great Bay Boulevard and Tuckerton marshes. Sheltered tidal flats actually occur between mean low water and mean high water but were found to be more common in the elevation range of zero to 31 or $37 \mathrm{~cm}(1.0$ or $1.2 \mathrm{ft})$.

\section{Results for Central New Jersey}

From these scenarios and the sedimentation rate of $5 \mathrm{~mm}(.2$ in) per year, we computed the net substrate elevation change for the year 2075, as shown in Table 3-3. Note in Table 3-3 that the combined sea level rise scenarios and sedimentation rate yield a positive change in substrate elevation for the baseline and a negative change for the low and high scenarios. The results of the scenario models for the New Jersey study area are given in Tables 3-4 and 3-5. Table 3-4 divides the number of acres in the study area and the percent of the area they cover according to principal zones. It shows existing coverage (1980) and the predicted coverage for the baseline, low, and high scenarios for the year 2075. Table 3-5 lists the net change in acres for each scenario compared with the coverage in 1980 . The baseline 2075 results are a projection of recent historical trends in sea level rise. 


\begin{tabular}{lcccccc} 
Scenario & \multicolumn{1}{c}{$\begin{array}{c}\text { Sea } \\
\text { Level Rise by } 2075\end{array}$} & $\begin{array}{c}\text { Average } \\
\text { Annual Rise }\end{array}$ & $\begin{array}{c}\text { Annual } \\
\text { Sedimentation } \\
\text { Rate }\end{array}$ & $\begin{array}{c}\text { Annual Net } \\
\text { Substrate } \\
\text { Change }\end{array}$ & $\begin{array}{c}\text { Substrate } \\
\text { Change } \\
\text { by } 2075\end{array}$ \\
Baseline & $+26.6 \mathrm{~cm}(0.87 \mathrm{ft})$ & $2.8 \mathrm{~mm}$ & $5 \mathrm{~mm}$ & $+2.6 \mathrm{~cm}$ & $+21 \mathrm{~cm}$ \\
Low & $+87.2 \mathrm{~cm}(2.86 \mathrm{ft})$ & $9.2 \mathrm{~mm}$ & $5 \mathrm{~mm}$ & $-4.2 \mathrm{~cm}$ & $-40 \mathrm{~cm}$ \\
High & $+163.4 \mathrm{~cm}(5.36 \mathrm{ft})$ & $17.2 \mathrm{~mm}$ & $5 \mathrm{~mm}$ & $-12.2 \mathrm{~cm}$ & $-116 \mathrm{~cm}$
\end{tabular}

TABLE 3-4

\section{NUMBER OF ACRES (PERCENT COVERAGE) FOR PRINCIPAL ZONES UNDER VARIOUS SCENARIOS AND DATES}

\begin{tabular}{|c|c|c|c|c|}
\hline Zone & Existing 1980 & Baseline 2075 & Low Scenario 2075 & High Scenario 2075 \\
\hline \multicolumn{5}{|c|}{ TUCKERTON MARSH (TIDAL RANGE $=2.0 \mathrm{FI})$} \\
\hline $\begin{array}{l}\text { Highland } \\
\text { Transition } \\
\text { High Marsh } \\
\text { Low Marsh } \\
\text { Tidal Flat } \\
\text { Water }\end{array}$ & $\begin{array}{rr}4,900 & (30) \\
1,200 & (7) \\
4,600 & (28) \\
300 & (2) \\
10 & (<1) \\
5,400 & (33) \\
\end{array}$ & $\begin{array}{rr}5,600 & (34) \\
4,600 & (28) \\
600 & (4) \\
200 & (1) \\
10 & (<1) \\
5,400 & (33) \\
\end{array}$ & $\begin{array}{rr}4,300 & (26) \\
1,100 & (7) \\
500 & (3) \\
4,800 & (29) \\
300 & (2) \\
5,400 & (33) \\
\end{array}$ & $\begin{array}{rr}2,600 & (16) \\
1,100 & (7) \\
500 & (3) \\
1,000 & (6) \\
700 & (4) \\
10,500 & (64) \\
\end{array}$ \\
\hline TOTAL & $16,400(100)$ & $16,400(100)$ & $16,400(100)$ & $16,400(100)$ \\
\hline \multicolumn{5}{|c|}{ GREAT BAY BOULEVARD MARSH (TIDAL RANGE $=3.18 \mathrm{FT})$} \\
\hline $\begin{array}{l}\text { Highland } \\
\text { Transition } \\
\text { High Marsh } \\
\text { Low Marsh } \\
\text { Tidal Flat } \\
\text { Water }\end{array}$ & $\begin{array}{rr}300 & (2) \\
200 & (1) \\
4,600 & (25) \\
200 & (1) \\
2,400 & (13) \\
10,600 & (58) \\
\end{array}$ & $\begin{array}{rr}500 & (3) \\
2,000 & (11) \\
2,700 & (15) \\
1,500 & (8) \\
2,400 & (13) \\
9,200 & (50) \\
\end{array}$ & $\begin{array}{rr}200 & (1) \\
200 & (1) \\
700 & (14) \\
3,300 & (18) \\
900 & (5) \\
13.000 & (71) \\
\end{array}$ & $\begin{array}{rr}30 & (<1) \\
30 & (<1) \\
30 & (<1) \\
200 & (11) \\
200 & (1) \\
17,800 & (97) \\
\end{array}$ \\
\hline TOTAL & $18,300(100)$ & $18,300(100)$ & $18,300(100)$ & $18,300(100)$ \\
\hline
\end{tabular}

Baseline 2075 and Low Scenario. Under existing trends, the model developed for this study, similar to Charleston, predicts a net increase in substrate elevation under the baseline condition where sedimentation rate exceeds sea level rise. As Tables 3-4 and 3-5 indicate, the biggest changes would be an increase in the transition zone area in the Tuckerton marsh and creation of more low marsh along Great Bay Boulevard. The percentage of highland would increase significantly with the addition of 900 acres, or 3 percent of the entire study area.

The low scenario implies a much different change in character of the study area. Under this model, net substrate elevation would decrease by the year 2075, but the change would be relatively small-around $40 \mathrm{~cm}$. A review of Tables $3-4$ and 3-5 and of Figures 3-5 and 3-6 shows the major impact would be a replacement of high marsh with comparable areas of low marsh. Overall, the number of acres of transition marsh, high marsh, and low marsh would almost exactly balance out. Most of today's tidal flats in the Great Bay Boulevard marsh subdivision would become inundated and add to the open water area. Higher mean water levels would displace approximately 700 acres of highland, killing plant species that cannot tolerate frequent tidal inundation (high-marsh species) but promoting growth of other species that can (low-marsh species).

Both the baseline and low scenario models represent relatively minor and gradual changes within the New Jersey study area. The net change in overall wetland acreage is insignificant. However, the distribution of each subenvironment will undergo major changes and profoundly affect marsh ecology. Since recent studies place a high probability on the low scenario in the future (Titus et al. 1984), the major trend in New Jersey would be replacement of high marsh with low marsh. Current low marsh and certain transition zones would be eliminated. 
TABLE 3-5

\section{NET CHANGE IN ACRES (AND PERCENTAGE) BETWEEN 1980 AND 2075 FOR PRINCIPAL ZONES UNDER VARIOUS SCENARIOS}
Zone
Baseline
Low Scenario
High Scenario

TUCKERTON MARSH (Tidal Range $=61 \mathrm{~cm}[2.0 \mathrm{FT}]$ )

$\begin{array}{lrrrrrr}\text { Highland } & +700 & (14) & -600 & (12) & -2,300 & (47) \\ \text { Transition } & +3,400 & (283) & -100 & (8) & -100 & (8) \\ \text { High Marsh } & -4,000 & (87) & -4,100 & (89) & -4,100 & (89) \\ \text { Low Marsh } & -100 & (33) & +4,500 & (1,500) & +700 & (233) \\ \text { Tidal Flats } & 0 & (0) & +300 & (3,000) & +700 & (7,000) \\ \text { Water } & 0 & (0) & 0 & (0) & +5,100 & (94)\end{array}$

TOTAL

GREAT BAY BOULEVARD MARSH (Tidal Range $\left.=96.9 \mathrm{~cm}\left[\begin{array}{ll}3.18 & \mathrm{FT}\end{array}\right]\right)$

$\begin{array}{lrrrrrr}\text { Highland } & +200 & (67) & -100 & (33) & -270 & (90) \\ \text { Transition } & +1,800 & (900) & 0 & (0) & -170 & (85) \\ \text { High Marsh } & -1,900 & (41) & -3,900 & (85) & -4,570 & (99) \\ \text { Low Marsh } & +1,300 & (650) & +3,100 & (1,550) & 0 & (0) \\ \text { Tidal Flats } & 0 & (0) & -1,500 & (63) & -2,200 & (92) \\ \text { Water } & -1,400 & (13) & +2,400 & (23) & +7,200 & (68)\end{array}$

TOTAL

FIGURE 3-5

CONCEPTUAL MODEL OF A LOW-SCENARIO SEA LEVEL RISE IN THE

TUCKERTON MARSH (Tidal Range $=2.0 \mathrm{ft}$ )

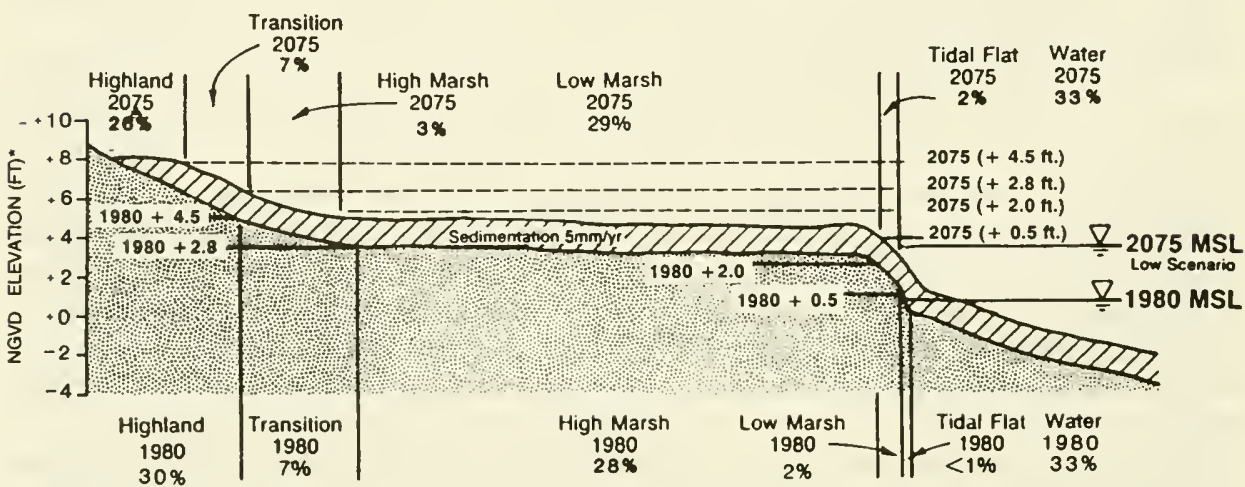

*Axis on left shows NGVD elevation; spot elevations are relative to 1980 or 2075 mean sea level. 


\section{CONCEPTUAL MODEL OF A LOW-SCENARIO SEA LEVEL RISE IN THE GREAT BAY BOULEVARD MARSH (Tidal Range $=3.18 \mathrm{ft}$ )}

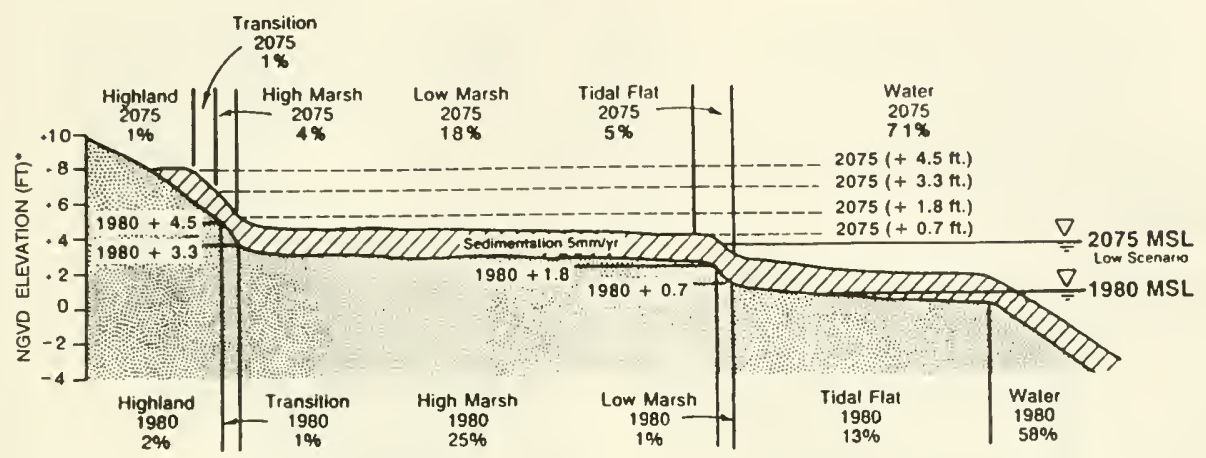

*Axis on left shows NGVD elevation; spot elevations are relative to 1980 or 2075 mean sea level.

In a gradual scenario, this change would be facilitated by the present distribution of species in the study area. Short S. alterniflora (present high marsh) would increase in area and adjust to rising sea level easily as taller forms. $S$. patens, which is currently dominant in many high-marsh areas, would recede inland since it is not adaptable to high water levels. It and many other highmarsh species would most likely disappear as they lost suitable high-marsh habitat and were compressed in narrowing zones between rising sea level and coastal development. A similar situation is now occurring where $S$. patens is declining in coastal areas and is being replaced by short S. alterniflora and Juncus gerardi is declining throughout (Niering and Warren, 1980). Seagrasses would also be affected and might increase in abundance as present stagnant depressions increased in depth and circulation.

A summary of the predicted effects of gradual sea level rise (low scenario), without human intervention and based on the adaptability of the plants, is presented in Table 3-6. Short $S$. alterniflora is listed as a significant loss; however, the plants would simply adapt to become taller forms. The critical losses in the high marsh would be Spartina patens, Distichlis spicata, and Juncus gerardi. Losses in Phragmites communis would be attributable to increased salinity as well as rising sea level.

High Scenario. The high scenario predicts a net decrease in substrate elevation of over one meter $(3.3 \mathrm{ft})$ by the year 2075 . Under this scenario, major land and marsh losses would occur throughout the study area. In the Tuckerton marsh, 2,300 acres of present highland would become inundated and almost 3,500 acres of marsh ( 57 percent) would be lost. Open water would almost double by 2075. In the Great Bay Boulevard marsh, over 90 percent of the existing wetlands would be lost. The percentage of open water would increase from 58 percent to 97 percent of the subdivision area. Overall for the New Jersey study area, about 50 percent of existing highland would become inundated, water areas would increase by over 75 percent, and marsh wetlands would decrease by over 70 percent. Figures 3-7 and 3-8 are conceptual models of the marsh loss in these two areas.

All of these estimates assume that wetlands form inland as sea level rises. For the Great Bay Boulevard marsh, this is reasonable. However, for much of the case study area, the land immediately inland of the marsh either is developed or could be developed in the next few decades. These areas would have to be abandoned for new marsh to form inland. Otherwise, the wetlands could be completely squeezed between an advancing sea and development, which does not retreat. 


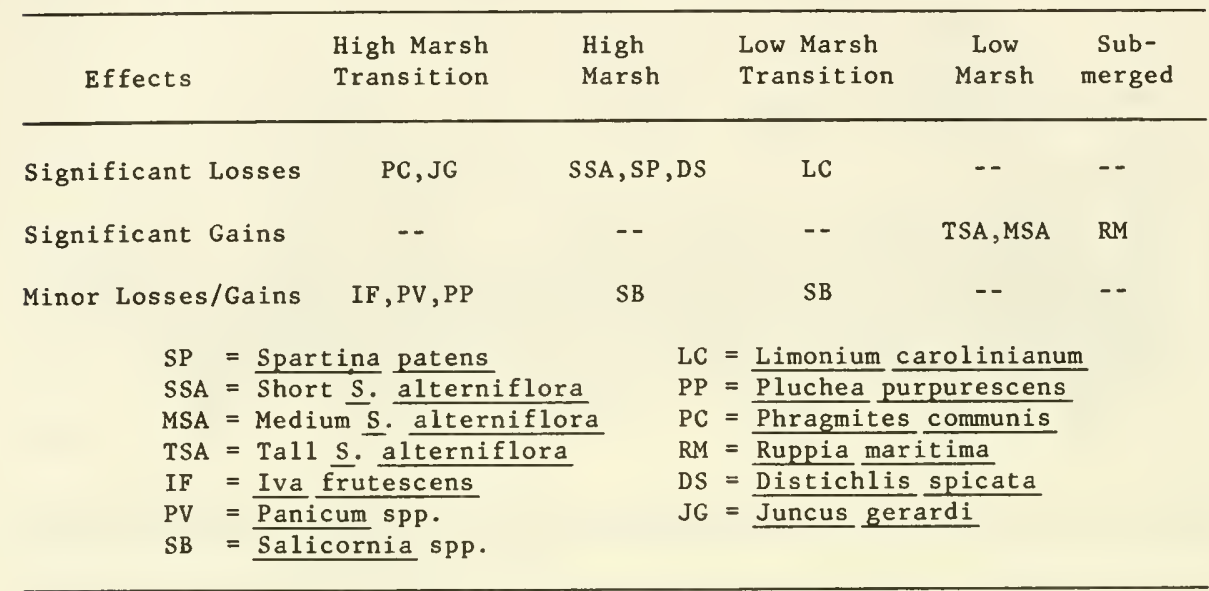

\section{FIGURE 3-7}

\section{CONCEPTUAL MODEL OF A HIGH-SCENARIO SEA LEVEL RISE IN THE TUCKERTON MARSH (Tidal Range $=2.0 \mathrm{ft}$ )}

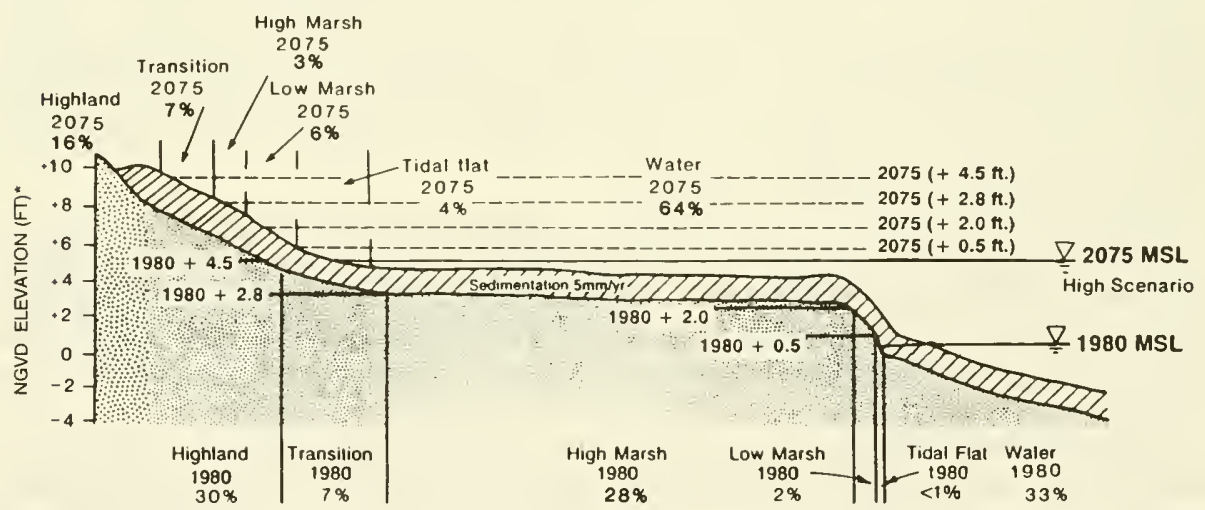

*Axis on left shows NGVD elevation; spot elevations are relative to 1980 or 2075 mean sea level.

Comparison with Charleston. The major difference between the responses of the New Jersey and Charleston coastal areas to accelerated sea level rise would be under the low scenario. In the case of Charleston, the more productive S. altemiflora low marsh would suffer significant net loss, whereas New Jersey would possibly gain slightly by a transformation from high marsh to low marsh. This difference is, of course, related to the significant difference in present distribution of high and low marsh for each area. Low marsh, which at present dominates in Charleston, would most likely become tidal flats; high marsh, which at present dominates the New Jersey study area wetlands, would become low marsh and actually promote the tall growth form of $S$. altemiflora.

Under the high scenario for both areas, 70-80 percent of existing wetlands would become submerged or transformed into tidal flats. There are significant potential impacts to highlands 


\section{CONCEPTUAL MODEL OF A HIGH-SCENARIO SEA LEVEL RISE IN THE GREAT BAY BOULEVARD MARSH (Tidal Range $=3.18 \mathrm{ft}$ )}

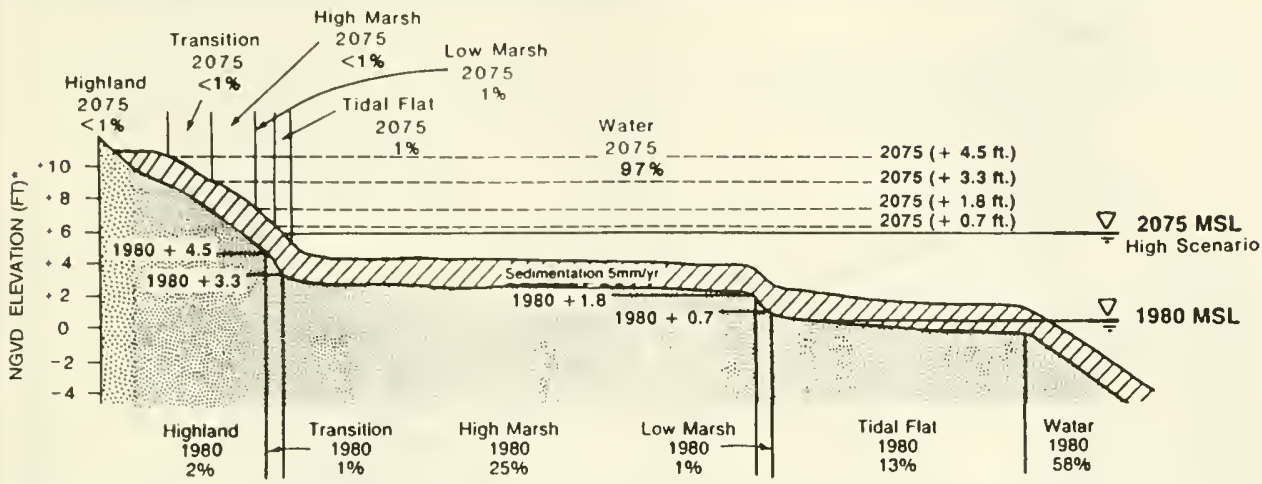

*Axis on left shows NGVD elevation; spot elevations are relative to 1980 or 2075 mean sea level.

suggesting that shore-protection measures would be considered in both study areas to protect existing developed land at marginal elevations above the marsh transition zone. The critical

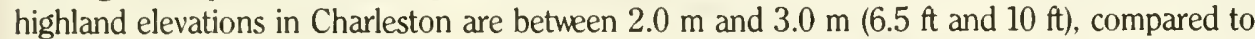

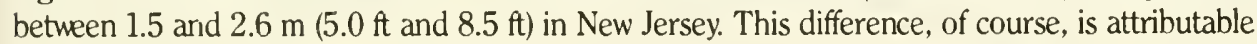
to the lower tidal range in New Jersey.

\section{Normalized Elevations}

The absolute modal elevation for each species is site-specific for the two marsh areas near Tuckerton. Presuming that the zonation is controlled primarily by tidal inundation, it is possible to normalize the data for variable tidal ranges based on frequency curves for each water level. Figure 3-9 contains a tide probability curve for Atlantic City, New Jersey, near the study area, based on detailed statistics of Atlantic Coast water levels given in Ebersole (1982). The left axis gives the absolute elevation with respect to local MSL, and the right axis has normalized the data as a function of the tidal range. Note that MHW and MLW, the average high and low water levels, respectively, plot at $\pm 0.50 \mathrm{ft}$ on the right-hand axis. This curve has been transformed in Figure 3-10 into a cumulative probability curve which is a measure of the relative duration of flooding at various tide levels.

The data are also normalized for the two specific tidal range areas in the New Jersey study area. Superimposed on the curves are the normalized modal elevations for key wetland species. The relative position of each species is the same, but note the displacement of the entire suite to higher levels in the 2.0-ft $(61-\mathrm{cm})$ tidal range marsh. Tall S. alterniflora occurs at predicted MHW in the Great Bay Boulevard marsh (elevation/tidal range $=0.50$ ), but at a much higher relative elevation in the Tuckerton fringing marsh (elevation/tidal range $=1.20 \mathrm{ft}[36.6 \mathrm{~cm}]$ ) -a difference of $0.7 \mathrm{ft}(21 \mathrm{~cm})$. Similarly, short S. alterniflora is displaced by an elevation/tidal range ratio of approximately 0.7 .

If marsh vegetation depends primarily on duration of inundation, one or both sets of these data would be immediately suspect. Therefore, we reviewed the data to determine possible sources of error. First, we compared the results with a similar curve for Charleston (Kana, Baca, and Williams, 1986, Figure 2-7B). The Charleston results are in good agreement with the Great Bay Boulevard marsh (96.9 cm [3.18 ft] tidal range) area. Tall S. alterniflora in New Jersey and low marsh $S$. alterniflora in Charleston both plotted at MHW. The cumulative duration of inundation (probability percentage) in both areas is $10-14$ percent. This is very close, given the limit of accuracy in the surveys. 


\section{TIDE-PROBABILITY CURVE-ATLANTIC CITY}

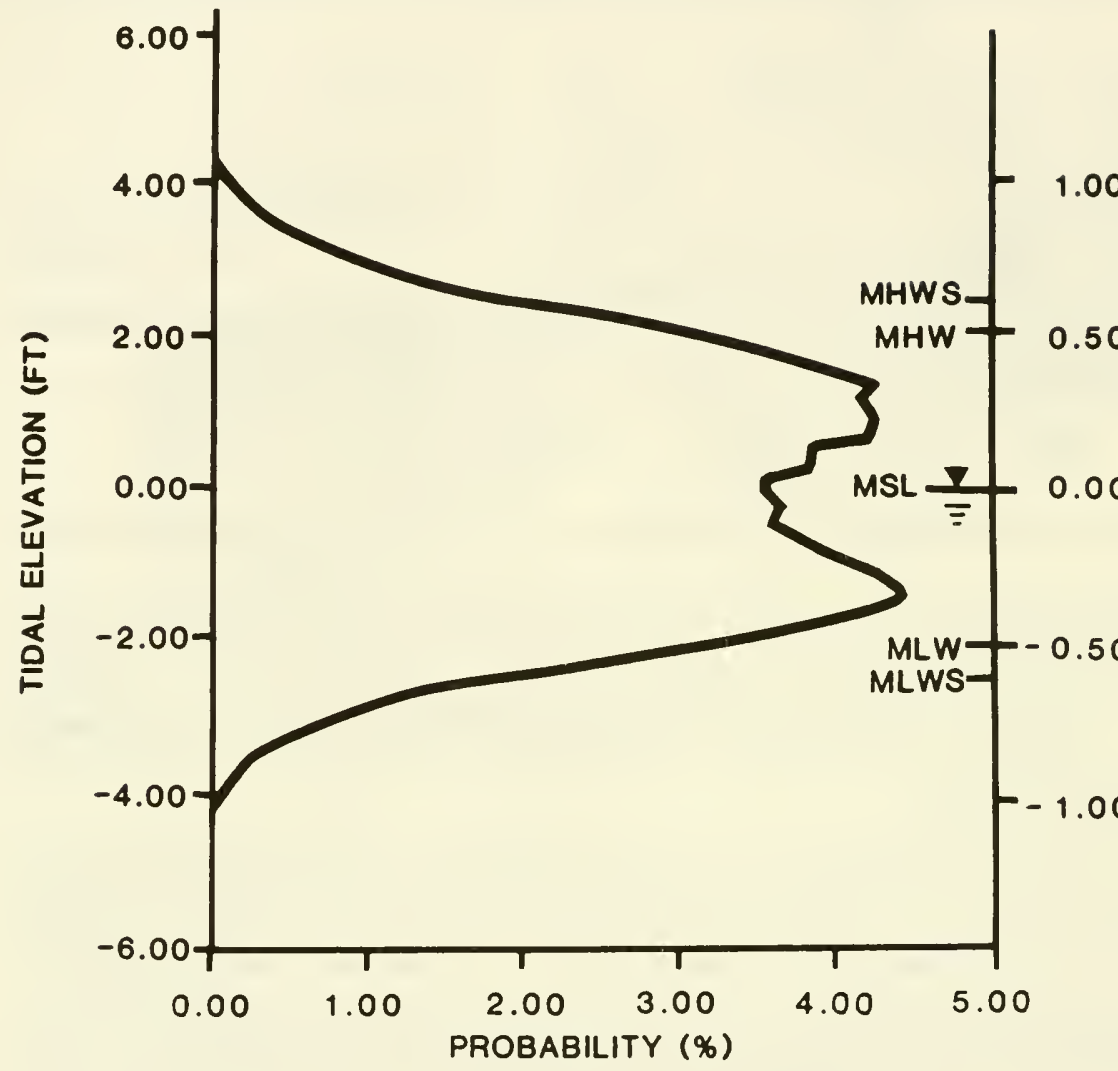

Tide-probability curve based on statistics for Atlantic City, New Jersey (near the study area), given in Ebersole (1982). The data are normalized on the right-hand axis for the local tide range. Abbreviations: MHWS (mean high water spring); MHW (mean high water); MSL (mean sea level); MLW (mean low water); MLWS (mean low water spring); Using local MSL as datum.

The Tuckerton marsh then does not seem to fit the model. This could be due to errors in the benchmark (E55) or tidal records used for the mainland marsh. However, after verifying the records with the National Oceanic and Atmospheric Administration (NOAA), we do not think this is a source of error. Also, tidal data were directly recorded in the immediate vicinity of the Tuckerton marsh transects at three localities as a check on each other by NOAA. The benchmark and tidal data are sufficiently modern to reflect present conditions so that subsidence or other factors are unlikely to account for the observed differences. This leaves the possibility that while the tidal range is less in the Tuckerton marsh, it is displaced upward as a result of impoundment of water or a difference in water flushing caused by extensive drainage canals. If this were the case, it would be a significant observation indicating the indirect but important effect of canalization on alteration of marsh zonation. 

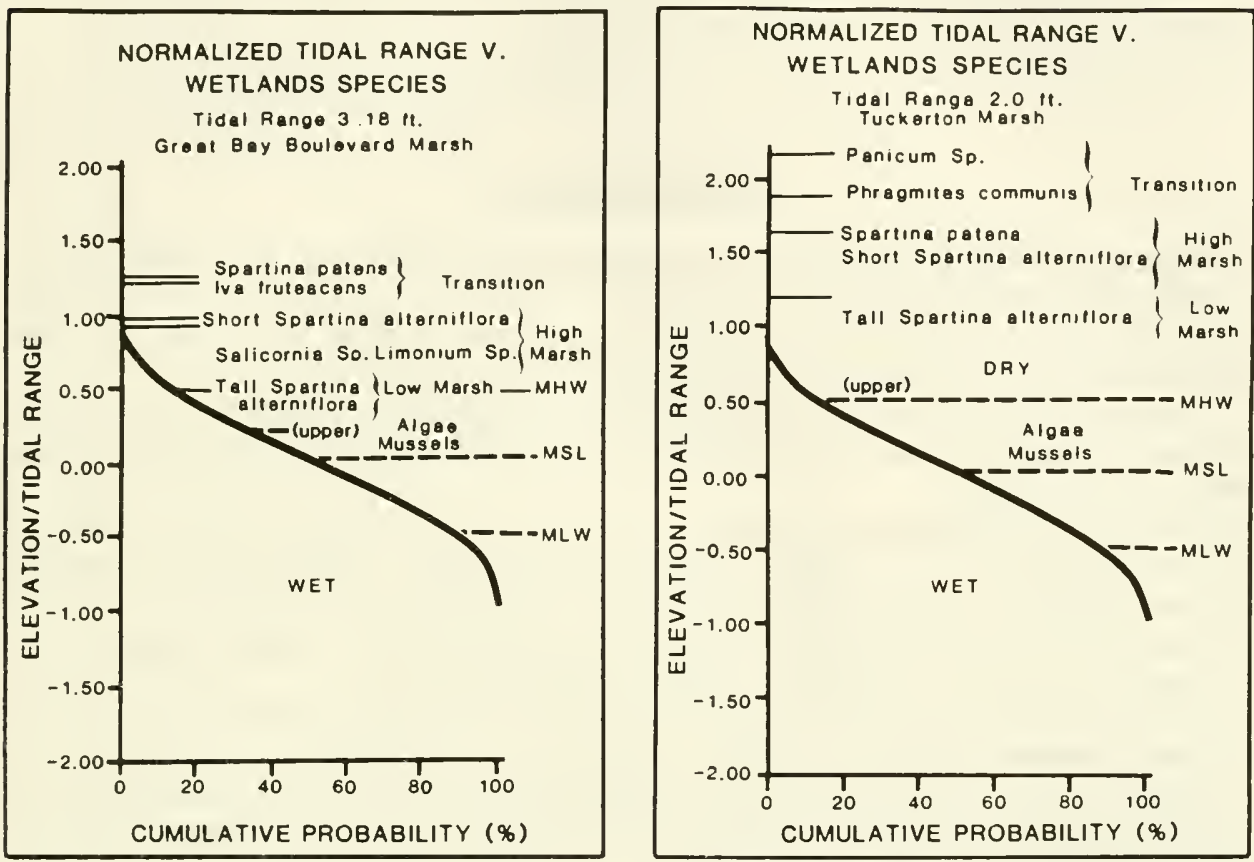

\section{CONCLUSIONS}

New Jersey's wetlands have been able to keep pace with the recent historical rise in sea level of thirty centimeters (one foot) per century. However, a one- to one-and-one-half-meter (three- to five-foot) rise would almost certainly be beyond the wetlands' ability to keep pace with the sea.

We estimate that a ninety-centimeter (three-foot) rise in relative sea level would result in a conversion of 90 percent of the study area's marsh from high marsh to low marsh. A large majority of the area's tidal flats could be expected to convert to open water. Although such changes would represent a substantial transformation, the predominance of high marsh in some sense provides a buffer against the impact of sea level rise. Many would view the conversion of high marsh to low marsh as acceptable.

The impact of a one-and-one-half-meter (five-foot) rise in sea level would be more severe. Such a rise would result in an 85 percent reduction of marsh and substantial reductions in the area of transition wetlands and tidal flats. The loss of marsh could be even greater if development just above today's marsh precludes the formation of new marsh as sea level rises.

This study did not examine options for increasing the proportion of coastal wetlands that survive an accelerating sea level rise. The institutional pressures to consider this issue may not be great until wetland loss from sea level rise accelerates. Nevertheless, our long-run efforts to protect coastal wetlands may be more successful if some thought is given to long-term measures while the issue is still far enough in the future for planning to be feasible. 


\section{NOTES}

${ }^{1}$ According to William Maddux of the New Jersey Department of Environmental Protection (personal communication, November 1984).

2 Plots of these profiles are available from the authors.

${ }^{3}$ The scenario referred to as "medium" in Barth and Titus is called "high" in this report.

\section{REFERENCES}

Adams, D.A., 1963. Factors influencing vascular plant zonation in North Carolina salt marshes. Ecol., Vol. 44, pp. 445-456.

Barth, M.C., and J.G. Titus (Eds.), 1984. Greenhouse Effect and Sea Level Rise. Van Nostrand Reinhold Co., New York, N.Y., 325 pp.

Boesch, D.F., D. Levin, D. Nummedal, and K. Bowles, 1983. Subsidence in Coastal Louisiana: Cases, Rates and Effects on Wetlands. U.S. Fish and Wildlife Serv., Wash., D.C., FWS/OBS-83/26, $30 \mathrm{pp}$.

Daiber, F.C., 1974. Salt march plants and future coastal salt marshes in relation to animals. R.J. Reimold and W.H. Queen (Eds.), Ecology of the Halophytes. Academic Press, New York, N.Y., pp. 475-508.

Duc, A.W., 1981. Back barrier stratigraphy of Kiawah Island, South Carolina. Ph.D. Dissertation, Dept. Geol., Univ. South Carolina, Columbia, 253 pp.

Ebersole, B.A., 1982. Atlantic Coast water-level climate. WES Rept. 7, U.S. Army Corps of Engineers, Waterways Experiment Station, Vicksburg, Miss., 498 pp.

Gagliano, S.M., 1984. Chap. 10, Independent reviews (comments of Sherwood Gagliano). In M.C. Barth and J.G. Titus (Eds.), Greenhouse Effect and Sea Level Rise, Van Nostrand Reinhold Co., New York, N.Y., Chap. 10, pp. 296-300.

Good, R.E., 1965. Salt marsh vegetation, Cape May, New Jersey. Bull. New Jersey Acad. Sci., Vol. 10, pp. 1-11.

Gosselink, J.G., and R.J. Baumann, 1980. Wetland inventories: wetland loss along the United States coast. Z. Geomorph., Suppl. 34, pp. 173-187.

Hatton, R.S., R.D. DeLaune, and W.H. Patrick, 1983. Sedimentation, accretion and subsidence in marshes of Barataria Basin, Louisiana. Limnol. and Oceanogr., Vol. 28, pp. 494-502.

Hayes, M.O., 1972. Forms of sediment accumulation in the beach zone. In R.E. Meyer (Ed.). Waves on Beaches, Academic Press, New York, N.Y., pp. 297-356.

Hayes, M.O., 1975. Morphology of sand accumulations in estuaries. In L.E. Cronin (Ed.). Estuarine Research. Vol. 2, Academic Press, New York. N.Y., pp. 3-22.

Hayes, M.O., 1979. Barrier island morphology as a formation of tidal and wave regime. In S.P. Leatherman (Ed.), Barrier Islands, Academic Press, New York, N.Y., pp. 1-27.

Hayes, M.O., and T.W. Kana (Eds.), 1976. Terrigenous Clastic Depositional Environments. Tech. Rept. No. 11-CRD. Coastal Research Division. Dept. Geol., Univ. South Carolina, 306 pp.

Hinde, H.P., 1954. The vertical distribution of salt marsh phanerogams in relation to tide levels. Ecol. Monogr., Vol. 24, pp. 209-225.

Kana, T.W., J. Michel, M.O. Hayes, and J.R. Jensen, 1984. The physical impact of sea level rise in the area of Charleston, South Carolina. In M.C. Barth and J.G. Titus (Eds.). Greenhouse Effect and Sea Level Rise. Van Nostrand Reinhold Co., New York, N.Y., Chap. 4. pp. 105-150.

Kana, T.W., B.J. Baca, and M.L. Williams, 1986. Potential Impacts of Sea Level Rise on Wetlands Around Charleston, South Carolina. Washington, D.C.: U.S. EPA. 
Lord, J.C., 1980. The chemistry and cycling of iron, manganese, and sulfur in salt marsh sediments. Ph.D. Dissertation. Univ. Delaware.

Meyerson, A.L., 1972. Pollen and paleosalinity analyses from a Holocene tidal marsh sequence. Cape May County, New Jersey. Marine Geology. Vol. 12, pp. 335-357.

Neiring, W.A., and R.S. Warren, 1980. Vegetation patterns and processes in New England salt marshes. BioScience, Vol. 30, pp. 301-307.

Nixon, S.W., 1982. The Ecology of New England High Salt Marshes: A Community Profile. U.S. Fish and Wildlife Serv., Wash., D.C., FWS/OBS-81/55, 70 pp.

Redfield, A.C., 1972. Development of a New England salt marsh. Ecol. Monogr., Vol. 42, pp. 201-237.

Reimold, R.J., J.L. Gallagher, C.A. Lindhurst, and W.J. Pfeiffer, 1975. Detritus production in coastal Georgia salt marshes. In L.E. Cronin (Ed.). Estuarine Research. Vol. 1. Academic Press, New York, N.Y., pp. 217-228.

Richard. G.A., 1978. Seasonal and environmental variations in sediment accretion in a Long Island marsh. Estuaries, Vol. 1. pp. 29-35.

Spinner, G.P., 1969. A plan for the marine resources of the Atlantic coastal zone. Amer. Geographical Society, $80 \mathrm{pp}$.

Stearns, L.A., and B. MacCreary, 1957. The case of the vanishing brick dust. Mosquito News, Vol. 17, pp. 303-304.

Stroud, L.M., and A.W. Cooper, 1968. Color infrared aerial photographic interpretation and net primary productivity of a regularly flooded North Carolina salt marsh. Water Resources Res. Inst., Rept. No. 14.

Teal, J.M., 1958. Energy flow in the salt marsh ecosystem. In Proc. Salt Marsh Conf., Inst., Univ. Georgia, pp. 101-107.

Titus, J.G., M.C. Barth, M.J. Gibbs, J.S. Hoffman, and M. Kenney, 1984. An overview of the causes and effects of sea level rise. In M.C. Barth and J.G. Titus (Eds.). Greenhouse Effect and Sea Level Rise. Van Nostrand Reinhold Co., New York, N.Y., Chap. 1, pp. 1-56.

Tumer, R.E., 1976. Geographic variations in salt marsh macrophyle production: a review. Contributions in Marine Science, Vol. 10, pp. 47-48.

U.S. Department of Commerce, 1979. State of South Carolina Coastal Zone Management Program and Final Environmental Impact Statement. Office of Coastal Zone Management, National Oceanic and Atmospheric Administration, Washington, D.C.

U.S. Department of Commerce, 1981. "Tide tables, east coast of North and South America." NOAA, National Ocean Survey, Rockville, MD., 288 pp.

Ward, L.G., and D.D. Domeracki, 1978. The stratigraphic significance of back-barrier tidal channel migration (Abs.). Geol. Soc. Amer., Abs. with Programs, Vol. 10(4), p. 201.

Wilson, K.A., 1962. North Carolina Wetlands: Their Distribution and Management. North Carolina Wildlife Resources Commission, Raleigh, N.C.

\section{APPENDIX 3-A}

\section{HISTOGRAM OF SPECIES OCCURRENCE}

Pages 84-86 show histograms of species occurrence for various species and tidal-range combinations based on the sixteen transects in the New Jersey study area. Only species having more than ten occurrences at $7.5-\mathrm{m}(25-\mathrm{ft})$ intervals were plotted. 
SHORT SPARTINA ALTERNIFLORA FREQUENCY HISTOGRAM

Tidal Range $=2.0 \mathrm{Ft}$.

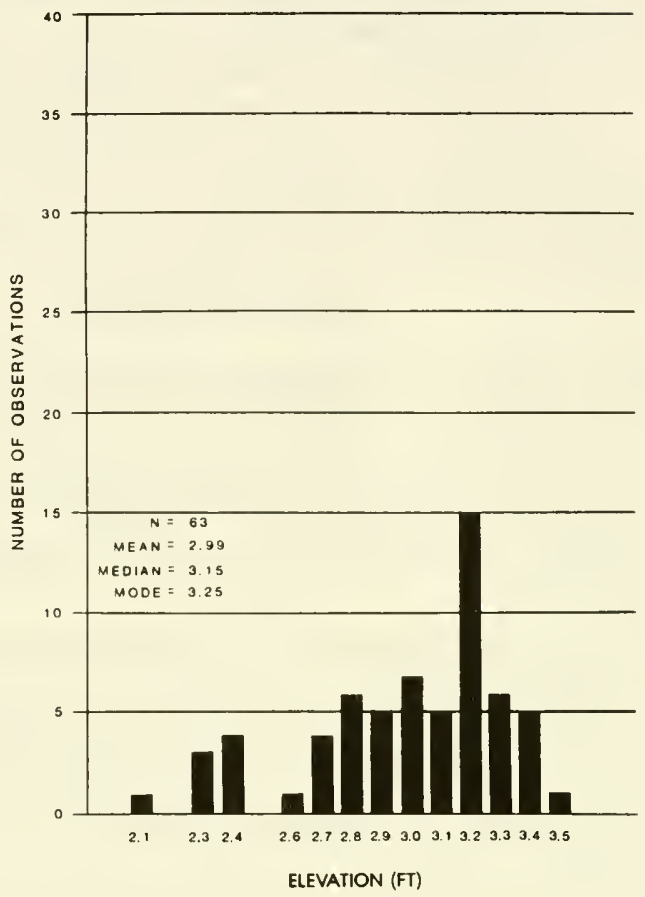

MEDIUM SPARTINA ALTERNIFLORA FREQUENCY HISTOGRAM

Tidal Range $=2.0 \mathrm{Ft}$.

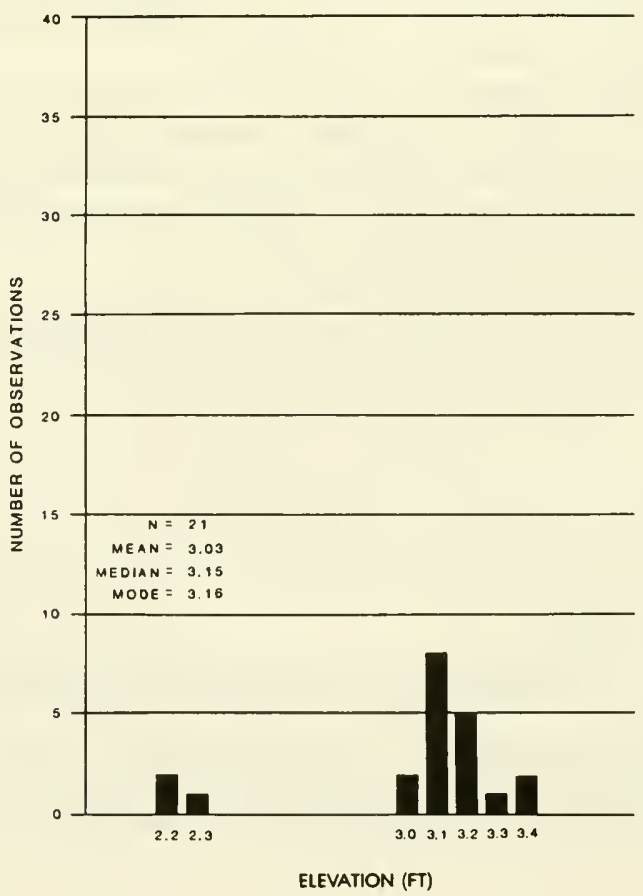


SPARTINA PATENS FREQUENCY HISTOGRAM

Tidal Range $=2.0 \mathrm{Ft}$.

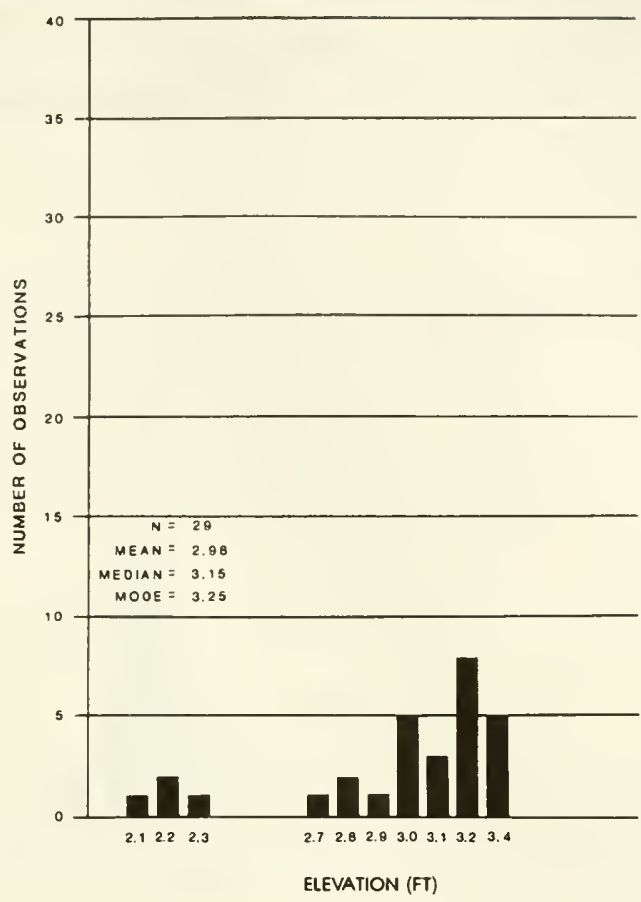

SHORT SPARTINA ALTERNIFLORA FREQUENCY HISTOGRAM Tidal Range $=3.18 \mathrm{Ft}$.

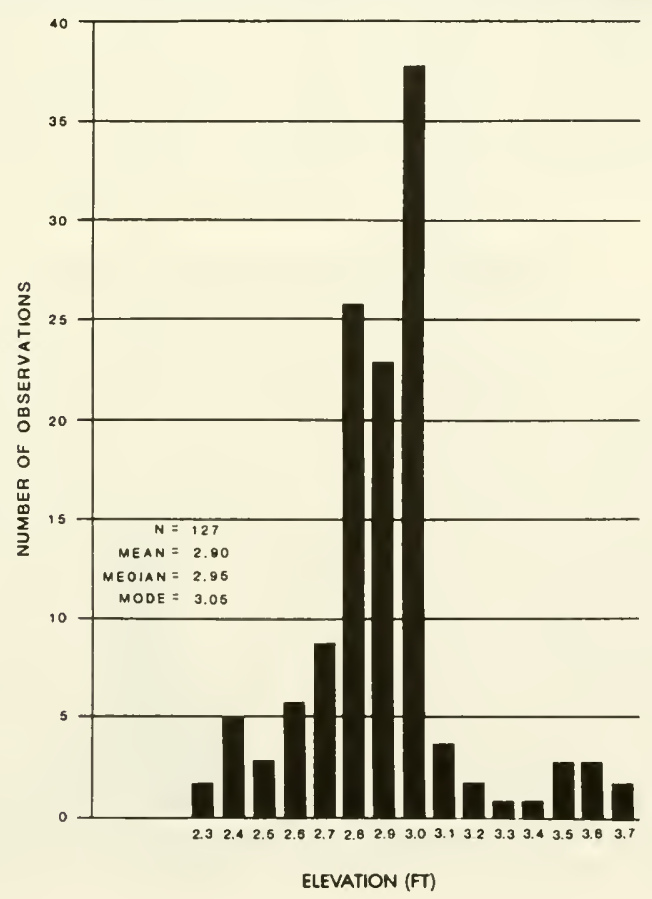


SALICORNIA SP. FREQUENCY HISTOGRAM

Tidal Range $=3.18 \mathrm{Ft}$.

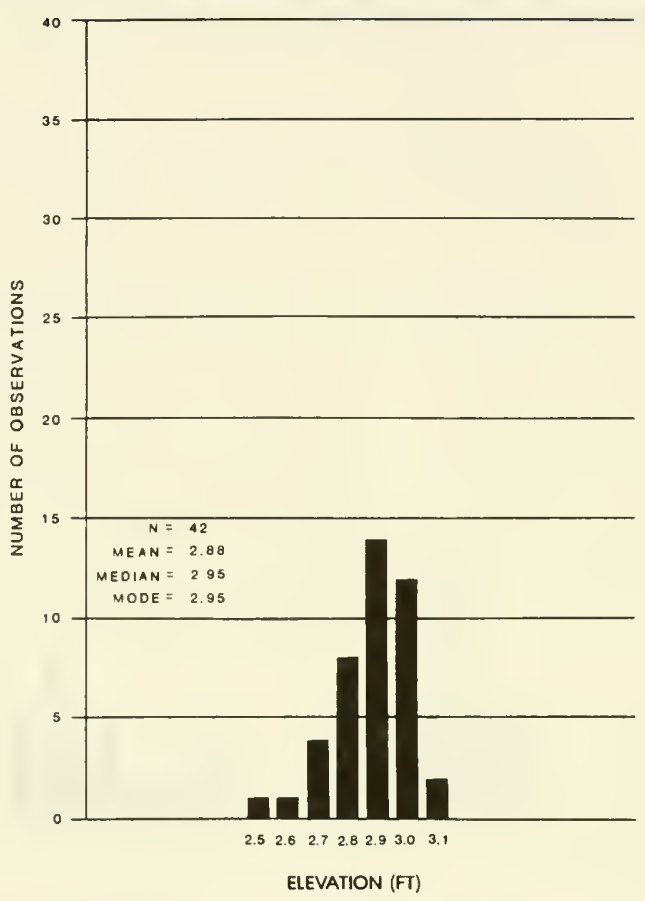

LIMONIUM CAROLINIANUM FREQUENCY HISTOGRAM

Tidal Range $=3.18 \mathrm{Ft}$.

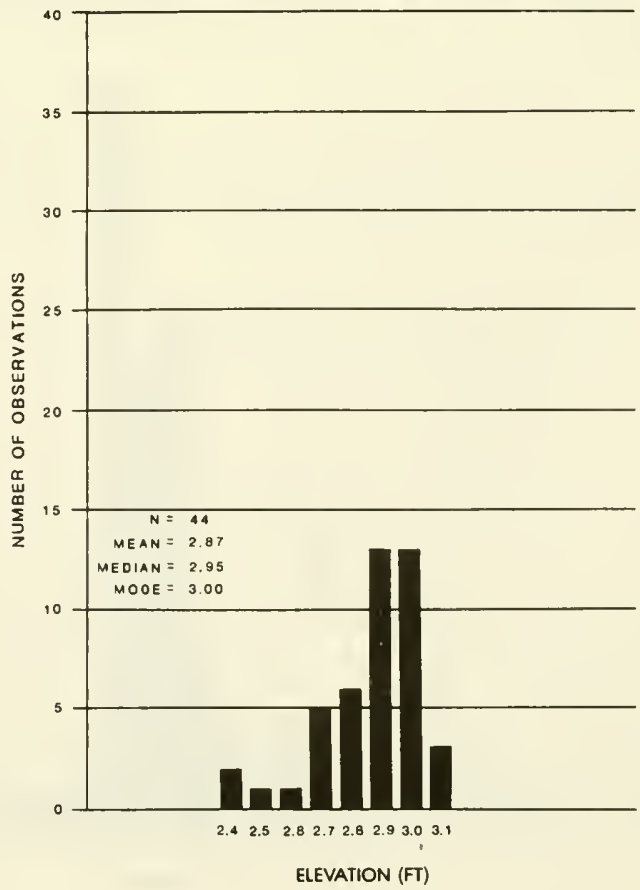




\title{
Chapter 4
}

\section{IMPACTS ON COASTAL WETLANDS THROUGHOUT THE UNITED STATES}

\author{
by \\ Thomas V. Armentano, Richard A. Park, C. Leslie Cloonan \\ Holcomb Research Institute \\ Butler University \\ 4600 Sunset Avenue \\ Indianapolis, Indiana 46208
}

\section{INTRODUCTION}

Although wetland responses to sea level rise can be estimated only in association with uncertainties inherent in making future projections, the major factors controlling wetland sea level responses can be modeled. This chapter considers possible coastal wetland responses to future sea level rise in the conterminous United States, in order to provide information needed to understand future threats to coastal resources during an anticipated period of unprecedented climatic change.

Our primary objectives have been to interpret our present understanding of wetland adjustments to sea level rise in terms of a future acceleration of present sea level rise rates, and to outline a method for projecting future regional-level responses that could result from global warming. The research focuses on relatively large-scale spatial patterns as opposed to specific site responses. Therefore, local features often are subsumed within more widespread characteristics in order to detect regional trends.

\section{SCOPE AND BACKGROUND}

The present study considers all coastal wetlands below $3.5 \mathrm{~m}$ elevation along the Atlantic, Gulf, and Pacific coasts of the conterminous United States. Among the wetland types considered, salt marshes predominate, although important brackish and freshwater marshes occur in each coastal region. In subtropical Florida, mangrove swamps usually replace salt marshes. Although all wetland types meeting the elevation criterion are considered, shifts between wetland types are not explicitly treated, for reasons given later.

The chief information base for this study consists of current knowledge of wetland adjustments to sea level rise inferred for the past several thousand years, particularly during the present century. The sedimentary sequence laid down under salt marsh conditions forms a record of coastal history, thus providing a basis for dating the location of the intertidal zone at various times in the past. In many areas, reconstruction of past shorelines and of sediment profiles reveals that the wetlands and sea level have been in approximate equilibrium for the past several millennia. This condition appears typical of many Atlantic coast wetlands. However, the pattern is not universal, and departures from this trend would be expected to influence wetland responses to accelerated sea level rise. Thus, in recent decades, Texas and Louisiana wetlands have been 
inundated by rising sea levels in response to land subsidence and reduced sediment supply (Davis 1985). Net loss of wetland area in Louisiana has resulted despite rapid vertical accretion rates (Hatton, Delaware, and Patrick 1983). Elsewhere, at various times in the recent past, expansion of wetlands has occurred (e.g., Redfield 1972).

Similarly, Johannesson (cited in Seliskar and Gallagher 1983) reports that the marsh advanced seaward into an Oregon estuary at over $21 \mathrm{~m}$ per year during 1887-1939, but has since slowed to about $0.15 \mathrm{~m}$ per year. However, in the current era such expansion appears restricted to local sites. Important factors determining wetland response to sea level rise include the topography of the wetland bottom, changes in upstream sediment supply and in growth rates of marsh vegetation, and more recently, the presence of artificial structures such as sea walls.

Salt marshes (saline wetlands) typically occupy zones bordering landward freshwater environments and marine or brackish bays and estuaries, except in highenergy tidal areas directly facing the open sea. However, under low energy conditions (e.g., the Florida panhandle), marshes may front the open sea. All salt marshes are technically defined as vegetated saline intertidal flats. Atlantic Gulf marshes originally covered about $2.02 \times 10^{6}$ ha (Davis 1985), and in the United States as a whole, about $3 \times 10^{6}$ ha in 1922 (Teal and Teal 1969). Since then, U.S. coastal wetlands were lost at a rate of 0.2 percent per year through 1954 , and 0.5 percent per year through 1974 (Gosselink and Bauman 1980). More recently, loss rates have diminished as a consequence of protective legislation (Tiner 1984).

Three major salt marsh groups are recognized in North America: (1) Bay of Fundy, New England, (2) Atlantic-Gulf Coastal Plain, and (3) Pacific. Along the Pacific coast only 10-20 percent of the coastal area is suitable for marsh buildup because marsh development has been limited by coastal uplift. In contrast, about 71 percent of the shoreline of the Atlantic and Gulf coasts is associated with mud deposits in estuaries, lagoons, or salt marshes (Emery and Uchupi 1972).

Salt marshes can be grouped into distinct vegetation zones determined by the extent of tidal inundation (Figure 4-1). In the Atlantic and Gulf areas, low marsh zones subject to protracted daily tidal flooding are dominated by Spartina altemiflora, except in subtropical latitudes. Along

\section{FIGURE 4-1}

\section{CROSS-SECTION OF A TYPICAL NORTHEASTERN ATLANTIC COAST SALT MARSH (from Tiner 1984)}

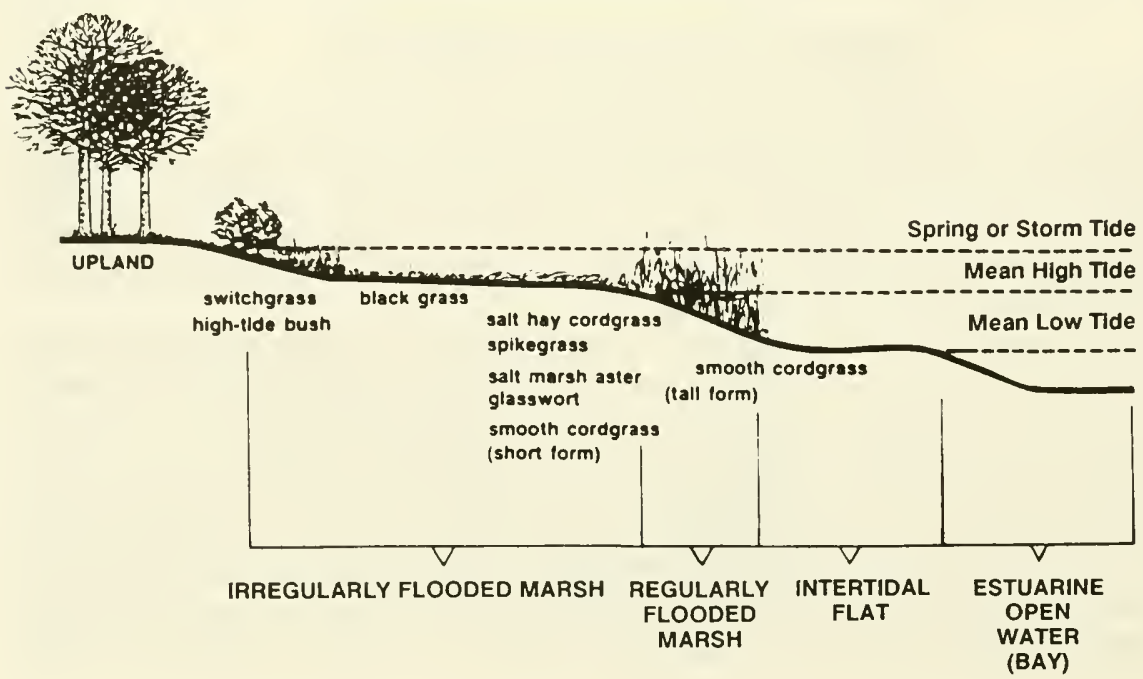


the Pacific, several species are found, including Salicomia virginica, Spartina califomicus, and Distichlis spicata. High marsh zones situated above daily high tides, but subject to spring and storm tides, are dominated by Spartina patens and Distichlis spicata in the east, Juncus roemerianus along the Gulf of Mexico, and by several species in the west, including Distichlis spicata, Juncus balticus, and Deschampsia caespitosa. Landward of the saline marshes, brackish and tidal freshwater marshes are found; these are particularly diverse and a number of subtypes have been defined for both the Atlantic and Pacific coasts. They are typified by salinities below $0.5 \mathrm{ppt}$ and often can be distinguished from freshwater marshes found beyond tidal influence along the Atlantic Coast (Odum and Fanning 1973). Tidal freshwater marshes are especially extensive in Louisiana, which contains 210,000 ha, or 30 percent of the total marsh area of the Mississippi Delta (Gosselink 1984).

\section{REGIONAL WETLAND DIFFERENCES RELEVANT TO SEA LEVEL ADJUSTMENTS}

Tidal range, tidal regularity, and substrate type influence marsh boundaries in relation to a specific tidal datum and therefore help determine adjustments to rising sea levels. Atlantic tides are regular and nearly equal in semidiumal range, whereas in the Pacific, tides exhibit a diurnal inequality. Gulf Coast tides are irregular but of small amplitude; thus the distinction between high and low marshes is less significant and the general marsh surface approximates mean high water. In Massachusetts, however, the low marsh corresponds to the upper-middle intertidal zone beginning between half-tide level and mean highwater neap. Along the Pacific coast, the low marsh ends at the landward edge at about mean highwater neap.

Regions also differ in their proportion of salt marsh types. Thus, New England marshes consist mostly of high marsh meadow, with low marsh plants found mostly along tidal creek borders (Miller and Egler 1950). South of Chesapeake Bay, low marshes increase in frequency. In Georgia about 60 percent of the marsh area is stream side-levee marsh and low-marsh meadow (Odum and Fanning 1973).

Along the Gulf, however, irregularly flooded Juncus roemerianus marsh may predominate. In southern Califormia, marshes exhibit a conspicuous middle-marsh zone between low and high zones. Despite the smaller marsh areas of the Pacific coast, its marsh floras are more diverse, tidal ranges are greater, and the resulting zonation more complex.

Northeastern Atlantic marshes commonly are dominated by brown or gray silt and clay overlain by thin peat. In New England, because most glacially derived silts and clays have been deposited in lakes and swamps or have been swept out to sea, less inorganic material remains available for marsh deposition (Meade 1969). Instead, thick peat beds have accumulated (Redfield $1965,1972)$ to depths as great as $59 \mathrm{~m}$ in offshore Pleistocene deposits. Inorganic sediments often dominate sediments where glacial deposits have been reworked or coarse materials have been ice-rafted to the marsh. Elsewhere in this region, however, organic material predominates in marsh peat (Armentano and Woodwell 1975).

South of Chesapeake Bay, peat substrates are relatively rare, except in Louisiana and Florida. In California, thick peat layers are rare and sediments contain little carbon. In the southeast, tidal flushing prevents peat accumulations as do rapid decay rates and slow rates of coastal submergence.

\section{PAST SEA LEVEL RISE AND MARSH ACCRETION}

Although scientists differ as to rates of sea level rise, all agree that the Holocene Epoch has been marked by a long-term trend of rising sea level (Figure 4-2). This transgression followed a great lowering of sea level during the Pleistocene when cooling climate triggered the advance of 


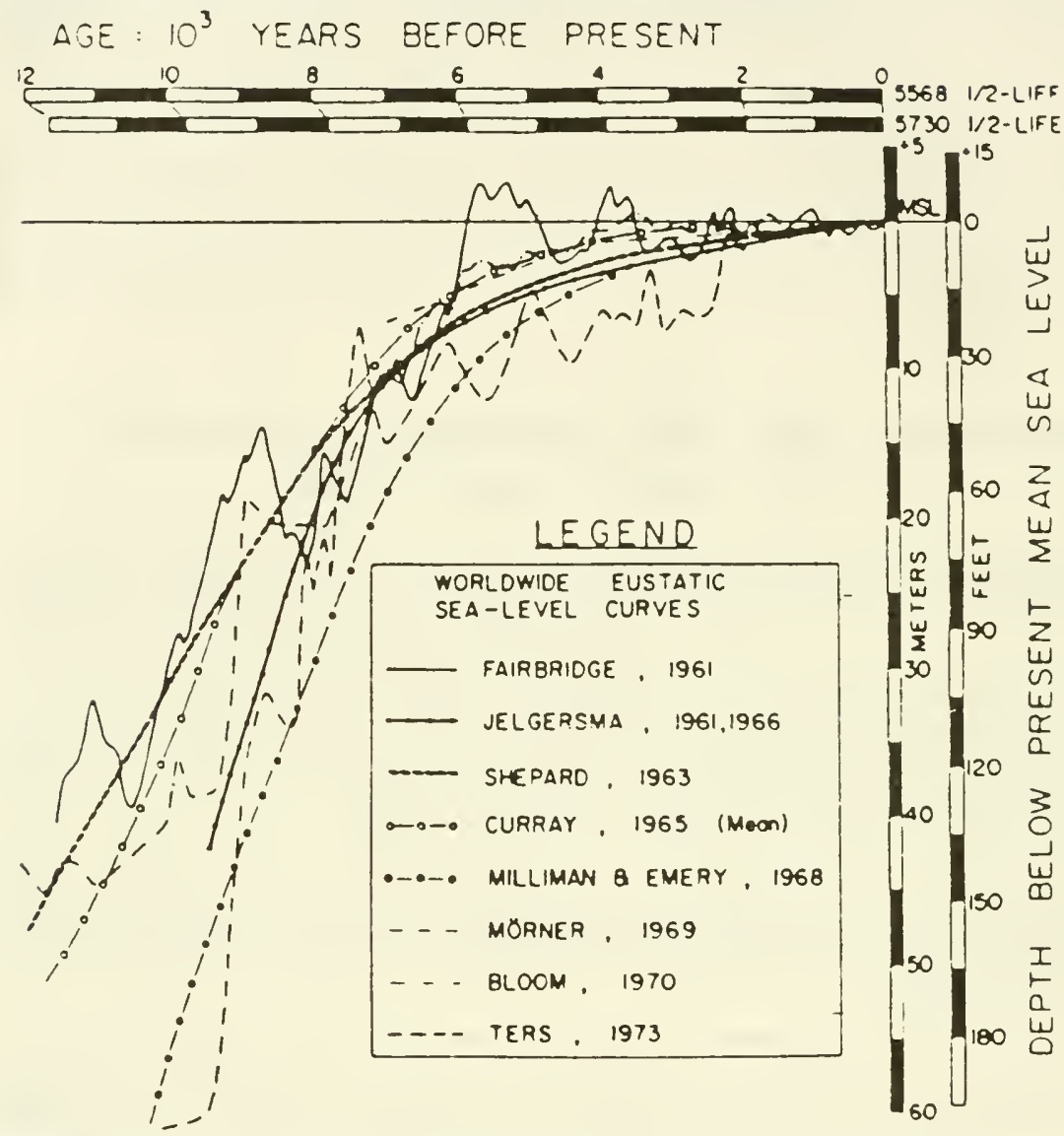

Estimates by various geologists as to the world's sea level over the past Holocene Epoch. The dominant cause of change is climatic, although tectonics and compaction effects are also involved (from Davis 1985).

polar ice sheets. Within the long-term pattern, short-term fluctuation in sea level, including temporary regression, occurred in response to shifts in climate and glacial movements. Overall, however, a period of rapid eustatic sea level rise, lasting about 4,000-5,000 years, accompanied the melting of Pleistocene glaciers. During this period, river valleys and adjacent coastal areas were drowned and marsh vegetation developed inland, but not extensively as long as sea level continued to rise rapidly. Thereafter, sea level rise slowed to near zero, but has continued gradually throughout, creating conditions favorable for marsh development and long-term accretion at rates equaling or exceeding sea level rise (Emery and Uchupi 1972, Redfield 1972, Davis 1985).

During the period of rising sea level, opposing isostatic uplift of the land surface in response to reduced glacial overload has occurred in some places, at rates sufficient to cause emergence of subtidal areas despite the rising sea level (Holmes 1965). Elsewhere (e.g., The Netherlands), land subsidence reinforces sea level rise effects. Typically, sea level records report only net heights that incorporate land surface movements. The relative significance of isostatic and eustatic effects is spatially variable; but in New England, based on carbon-14 dating of marsh peat, eustatic sea 
level rise has accounted for about 80 percent of the rising shoreline over the past 2-3,000 years (Nixon 1982).

The rate of sea level rise during the rapid phase beginning 11-12,000 years ago reached as high as $16 \mathrm{~mm}$ per year over the Texas coastal shelf and $8 \mathrm{~mm}$ per year over the Atlantic coastal shelf (Emery and Uchupi 1972). These values are mean rates determined from regression lines of radiocarbon dating for the period from 1,000 to 15,000 years ago. The Atlantic rate appears typical of most shelf areas of the world. The Texas rate suggests that the shelf itself has subsided relative to most other shelf areas (Emery and Uchupi 1972).

Results from a variety of radiocarbon studies of peat deposits from present subtidal areas show that during the past 4,000 years, sea level has risen 3-6 m (Emery and Uchupi 1972). In general, during the past several thousand years, eustatic sea level rise has averaged around $1 \mathrm{~mm}$ per year. Intervals of no net rise have been deduced from past records, as have periods of more rapid rise. Typical rates as measured at several northeastern tidal stations in the United States are given in Table 4-1. A larger number of tidal station records, broken down regionally and corrected for latitudinal effects, is available in Hicks (1978) for the entire country. These records show that sea level rise over the period 1940-1975 has averaged $1.5 \mathrm{~mm}$ per year for the conterminous United States. However, within regions and shorter time periods, deviations from the mean are common. Thus, submergence of the Connecticut coast has averaged $2.6 \mathrm{~mm}$ per year from 1940 to 1972, with an anomalous rate of $10 \mathrm{~mm}$ per year from 1964 to 1972 , a rate approaching late glacial eustatic transgression (Harrison and Bloom 1977).

\section{TABLE 4-1 \\ RATES OF Net SEA LEVEL RISE ALONG the NORTHEAST ATLANTIC COAST (from Nixon 1982)}

LONG-TERM RATES (over the past $2-3,000$ years). Data of Bloom and Stuiver (1963), Redfield (1967), Keene (1971), Oldale and O'Hara (1980), and Rampino and Sanders (1980).

$\mathrm{ft} /$

$\begin{array}{lcc}\text { Location } & \mathrm{mm} / \mathrm{yr} & \text { century } \\ \text { New Hampshire } & & \\ \text { Northeastern MA (probably also NH and ME) } & 0.1 & 0.36 \\ \text { Southeastern MA: } & 1.0 & 0.26 \\ \text { Cape Code to Virginia } & 1.1 & 0.33 \\ \text { Connecticut } & 0.9 & 0.36 \\ \text { Long Island, NY } & 1.0 & 0.33\end{array}$

SHORT-TERM RATES (1940-1975) from tidal gauge records. From Hicks (1978).

Location

$\mathrm{ft} /$

$\mathrm{mm} / \mathrm{yr}$ century

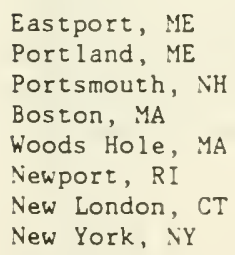

$\begin{array}{ll}3.5 & 1.15 \\ 2.0 & 0.66 \\ 1.8 & 0.60 \\ 1.5 & 0.49 \\ 2.9 & 0.95 \\ 2.5 & 0.82 \\ 2.6 & 0.85 \\ 3.1 & 1.02\end{array}$

*The published value of $0.01 \mathrm{~m} / 00 \mathrm{yr}$ is a typographical error in Oldale and O'Hara (1980) [Nixon 1982]. 
Under conditions of slow sea level rise or short-term equilibrium, salt marsh establishment and growth can occur. In fact, some observers conclude that marsh formation can occur only under these conditions. However, others have noted that salt marshes generally, with the exception of Gulf Coastal areas, have kept pace with sea level rise even in the past 35 years when the rate of sea level rise has increased noticeably (Nixon 1982). Under favorable conditions, young salt marshes can accrete at very high rates. Redfield (1972) found that Spartina altemiflora sediments accreted at over $50 \mathrm{~mm}$ per year in Barnstable marsh (Massachusetts). Generally, however, rates are far slower and may exceed measured sea level rise rates by only a small amount (Table 4-2). According to McCaffrey (cited in Nixon 1982), salt marshes may continue to accrete even during a short period of sea level decline.

The factors principally responsible for determining accretion rates are sediment loads, current velocity, and flooding frequency and duration. Local site differences in these factors account for differences among and within marshes. Thus, in low, silty Oregon marshes, accretion rates varied between 5 and $17 \mathrm{~mm}$ per year (Seliskar and Gallagher 1983). Five high marshes in Connecticut varied in sediment accretion from $2.0-6.6 \mathrm{~mm}$ per year in correlation with tidal range and therefore increased flooding (Harrison and Bloom 1977). Year-to-year differences were attributed to storm frequency, with greater accretion during storm years. Conditions are similar along the Pacific coast where studies in British Columbia and Oregon showed that most deposition occurred during a few annual storms (Seliskar and Gallagher 1983).

Based on Table 4-2, accretion rates do not appear to increase with decreasing latitude, although marsh productivity does. However, Mississippi Delta marshes appear to accrete at exceptionally high rates, suggesting that local sedimentation and sea level rise rates may be more important than climate in determining accretion rates. Most studies indicate that low marsh zones, in contrast to high marsh zones, have been accreting over the measurement period at a rate clearly exceeding sea level rise rate. Conspicuous exceptions are found throughout the Mississippi Deltaic Plain, at least in interdistributary back marshes (Table 4-2), although on levees rapid accretion exceeds the sea level rise rate. Particularly in Louisiana, and to a lesser extent elsewhere, measured sea level rise clearly is a net rate that includes a significant downwarping effect from coastal overburden. Furthermore, the potential capacity of Louisiana salt marshes to accrete cannot be determined from measured rates because of significant interruption of normal fluvial sedimentation processes by human alteration of Mississippi River flowages (Hatton, DeLaune, and Patrick 1983; Gosselink 1984).

Accretion in high marshes has seldom been studied, but as found by Harrison and Bloom (1977), rates are below those of low marshes probably because delivery of suspended sediment in tidal waters is greatly reduced. Although increasing sea level rise might be expected to increase sediment supplies and in situ productivity in high marsh, gradual conversion to low marsh might occur when the threshold tolerance for exposure and flooding of Spartina alterniflora and $S$. patens, respectively, is exceeded.

Few data are available on sedimentation rates in coastal brackish and freshwater marshes. In Louisiana, accretion in freshwater marshes appears to be only marginally less than in salt marshes, indicating the continuing (although reduced) importance of fluvial sediment sources as well as high productivity rates (Table 2, Hatton, DeLaune, and Patrick 1983). In other areas, sedimentation in coastal freshwater marshes can be inferred for sites of considerable age, given the influence of rising sea levels. However, further data must be sought on fresh and brackish sites before conclusions can be drawn as to their capacity for responding to accelerated sea level rise. 


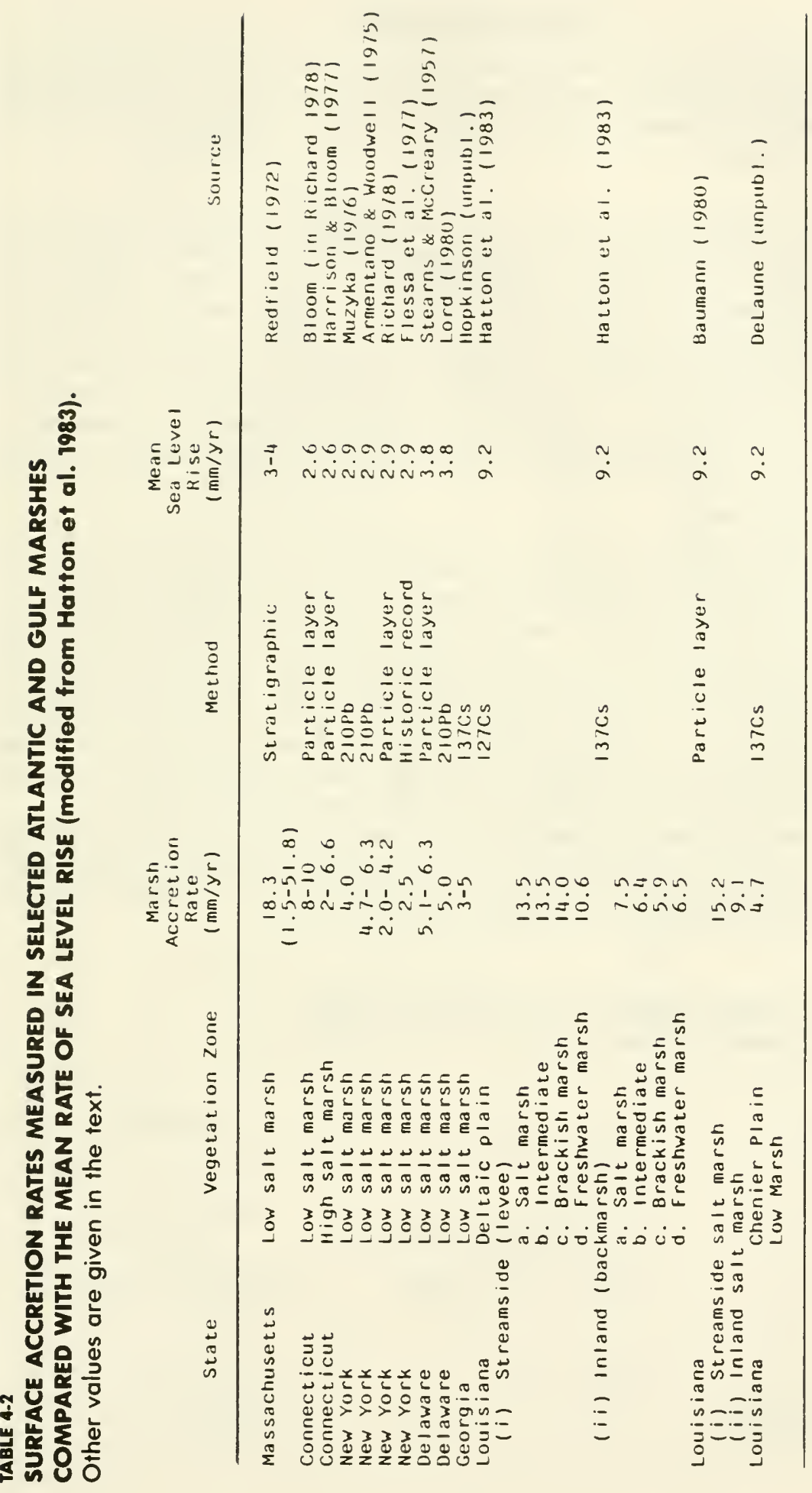




\section{METHODOLOGY}

The objectives of the present study were met in a two-step procedure: (1) interpretation of the present distribution of coastal land categories and their attributes pertinent to sea level rise, and (2) development of a computer model to simulate the future response of the coastal land categories to postulated rates of sea level rise. Both are described in detail below.

\section{Data}

To develop a regional/national analysis of U.S. coastal wetland responses to sea level rise, stratified sampling of the continuous U.S. coastline was undertaken for nine regions (Figure 4-3). Selected 7.5-minute quadrangles were characterized as to coastal features, elevation, and development. The quadrangles were selected to capture, to the extent possible, the variation in coastal landscapes within each region. In addition, within each region, important lagoonal and deltaic wetlands were analyzed (Table 4-3). The sites interpreted for the present study are shown for each region of the United States in Figures 4-4 through 4-7. A total of 183 quadrangles were used for the 57 sites depicted. The entire case study data set is presented as Appendix 4-A. Although the sites are representative of the coastal wetlands, they do not constitute a statistical sample from which probabilistic inferences can be made concerning all coastal areas of the contiguous United States.

The data were collected from each $1 \mathrm{~km}^{2}$ cell registered on the Universal Transwerse Mercator (UTM) grid so that re-inventorying would be routine. Of the sixteen categories of coastal types, each is based on the dominant category within the square-kilometer cell. They are summarized in Table 4-4. The type of coastline is defined as one of the following: (1) steep slope, (2) low slope, terraced, (3) deltaic, and (4) low slope, unterraced. The height of low coastal terrace is estimated for each site and region from the literature (e.g., Richards 1962); however, it is not used in the current version of the simulation model. The mean elevation is based on the dominant category in the cell. Although this introduces an element of imprecision, if a large enough area is considered, the estimate is not biased. Tidal range for both open sea and sheltered areas is taken from the topographic maps, or if necessary from tide tables.

The presence of naturally sheltered areas (e.g., bays) is coded, as are major protective structures such as levees. Finally, the extent to which the cell can be classified as residentially or commercially developed is noted. The extent of freshwater and brackish wetlands cannot be determined at the regional level from topographic maps.

\section{TABLE 4-3}

\section{REGIONAL CLASSIFICATION OF COASTAL WETLANDS AND REPRESENTATIVE SAMPLE SITES}

\begin{tabular}{lll}
\hline \multicolumn{1}{c}{ Region } & \multicolumn{1}{c}{ Deltaic } & Lagoonal \\
\hline New England & Narragansett Bay (RI) & Barnstable Marsh (MA) \\
Atlantic & $\begin{array}{l}\text { Charleston area (SC) } \\
\text { James River/Chesapeake Bay }\end{array}$ & Sapelo Island (GA) \\
Gulf Coast & $\begin{array}{l}\text { Apalachicola Bay (FL) } \\
\text { Mississippi River (LA) }\end{array}$ & $\begin{array}{l}\text { Fort Walton Beach (FL) } \\
\text { Galveston Bay (TX) }\end{array}$ \\
$\begin{array}{l}\text { Pacific } \\
\text { Temperate } \\
\text { Dry Mediterranean }\end{array}$ & $\begin{array}{l}\text { Yaquina (OR) } \\
\text { Tropical-Subtropical } \\
\text { Santa Ynez River (CA) }\end{array}$ & $\begin{array}{l}\text { Coos Bay (OR) } \\
\text { Cabillo NM (CA) }\end{array}$ \\
\hline
\end{tabular}




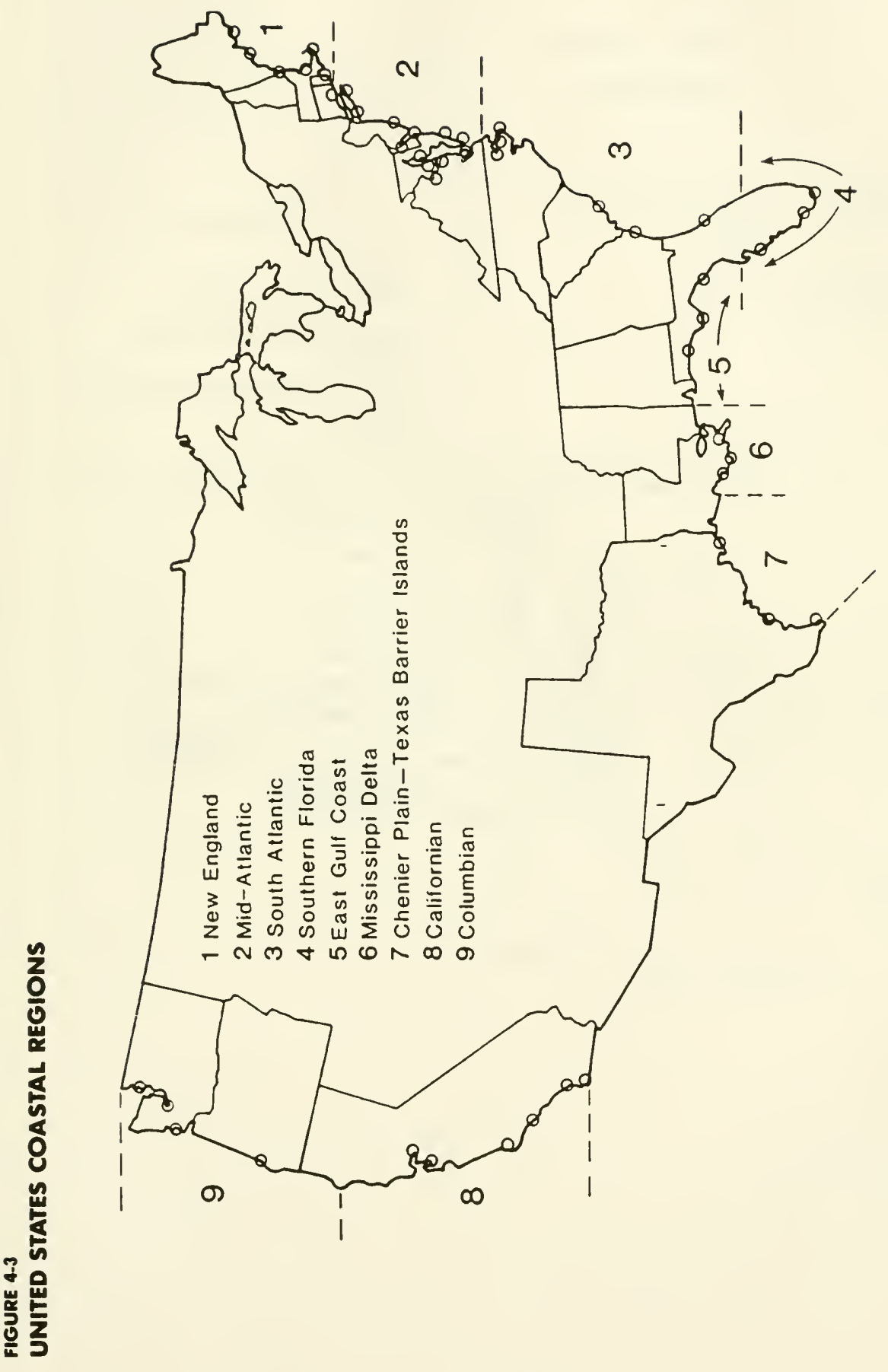


1 New England

2 Mid-Atlantic

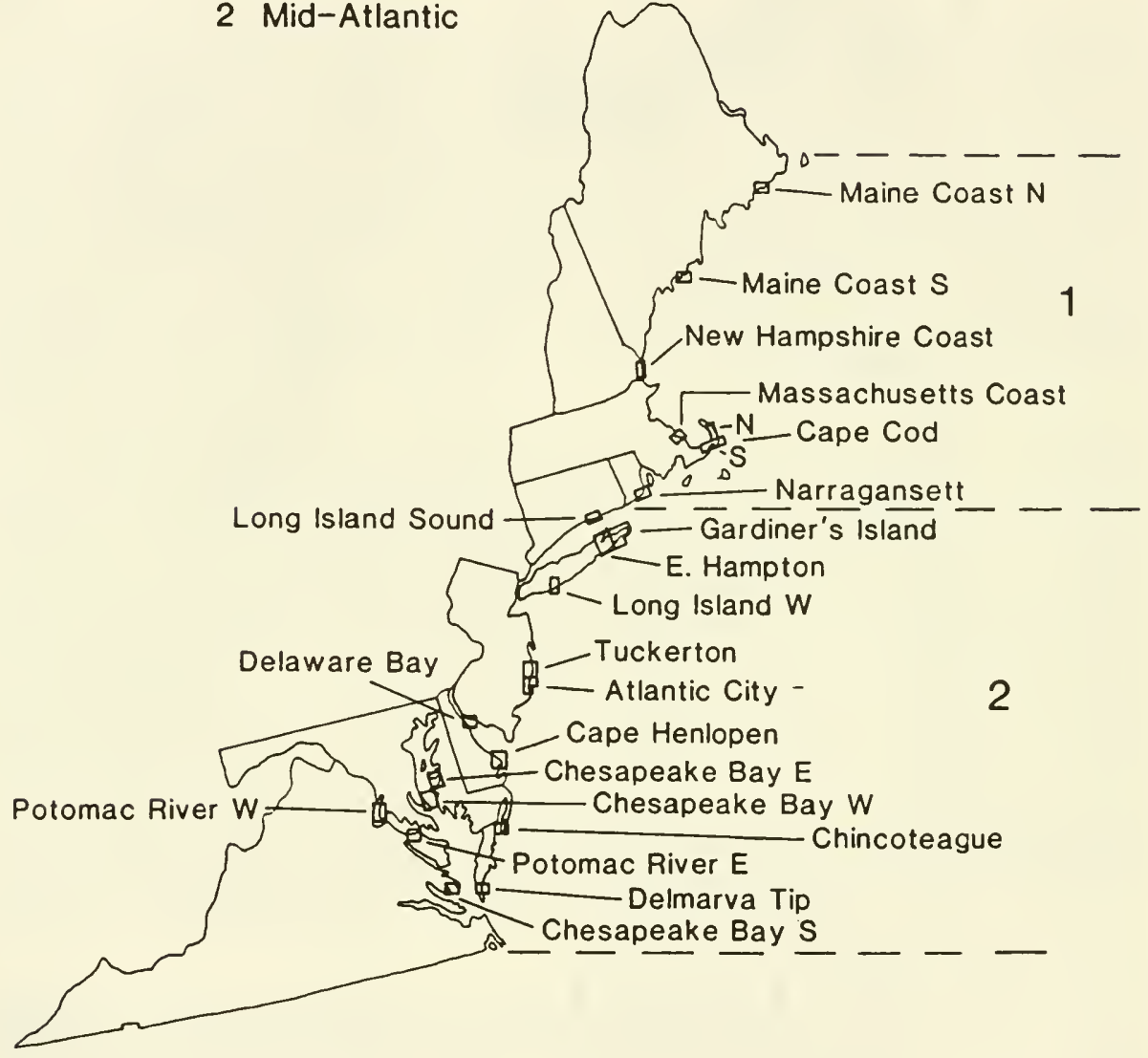


3 South Atlantic

4 Southern Florida

5 East Gulf Coast

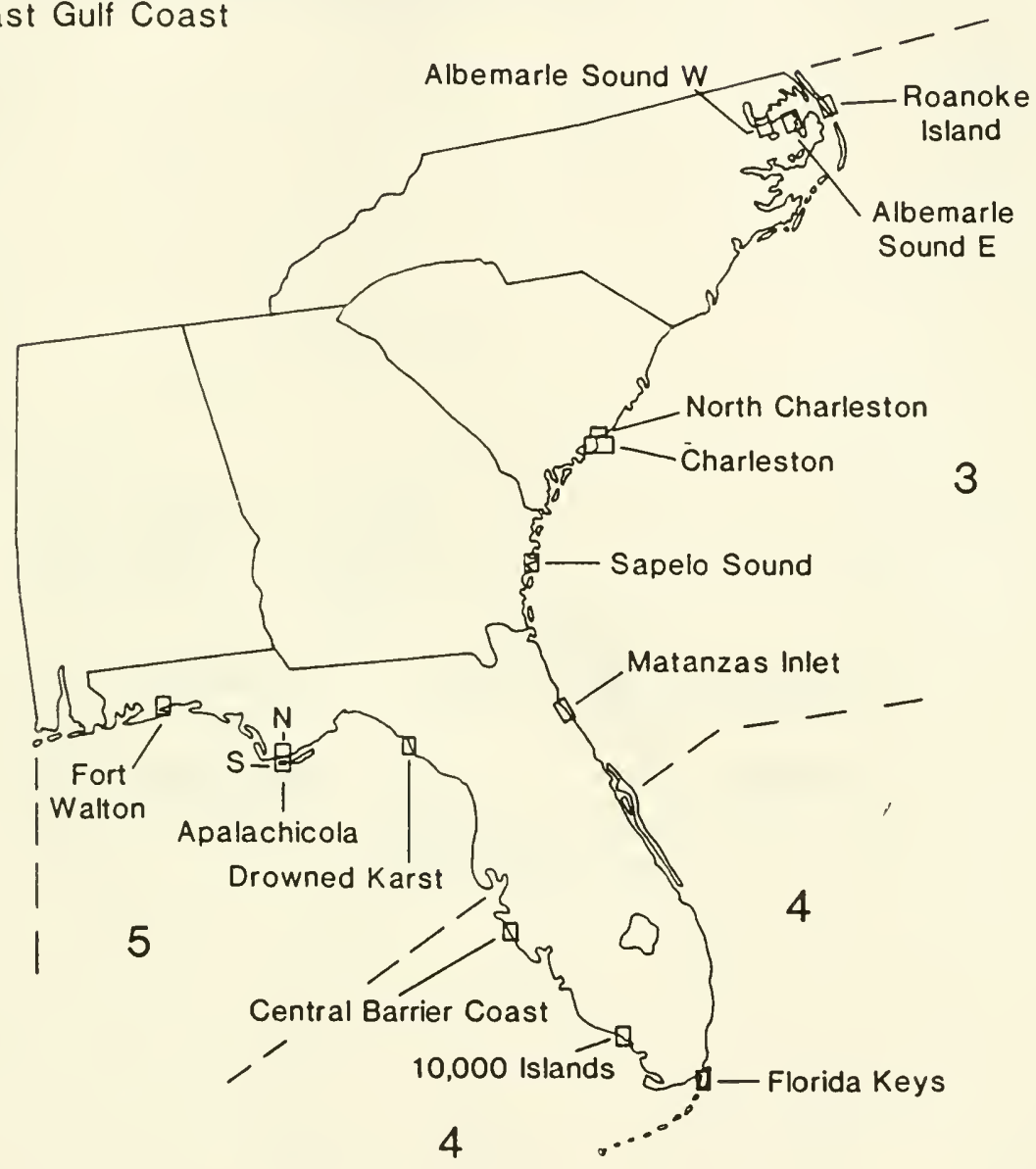


6 Mississippi Delta

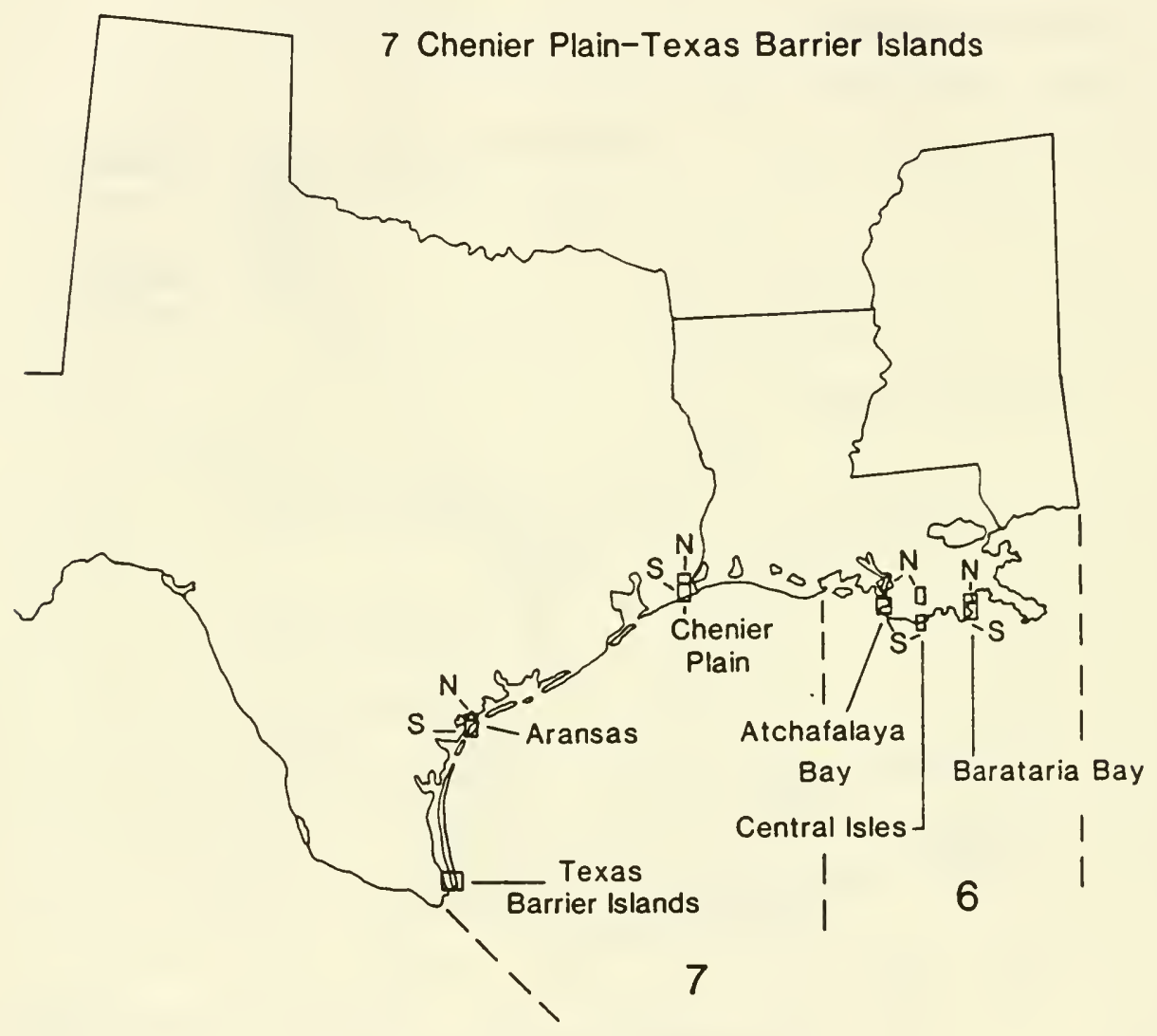




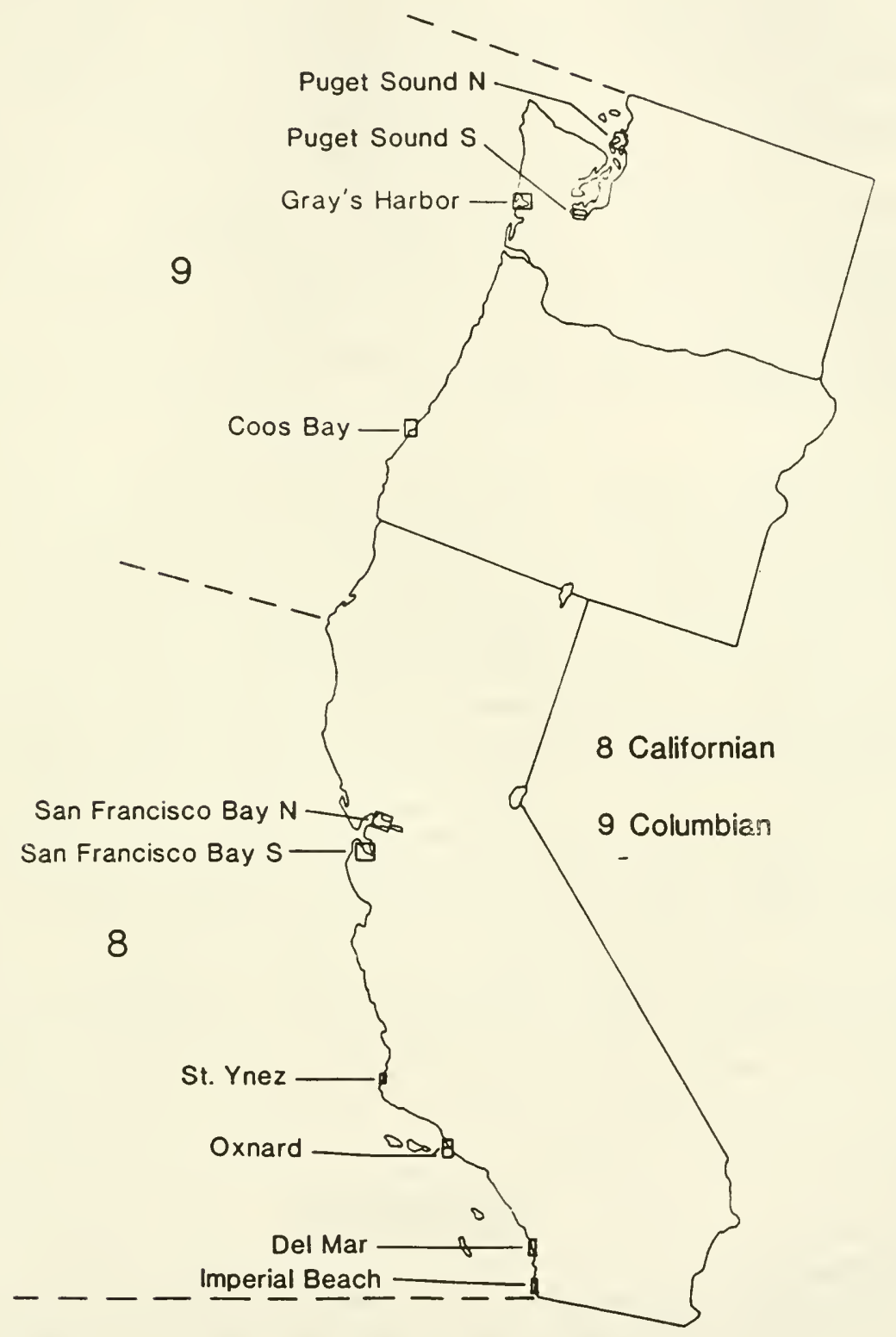


Undeveloped Upland

Developed Upland

Undeveloped Lowland

Developed Lowland

Protected Lowland

High Dunes

Exposed Beach

Sheltered Beach

Developed Exposed Beach

Developed Sheltered Beach

Freshwater Marsh

Salt Marsh

Mangrove Swamp

Tidal Flat

Sheltered Water

Open Water
Undeveloped upland above $3.5 \mathrm{~m}$ elevation

Upland with significant residential or commercial development

Land below $3.5 \mathrm{~m}$ elevation and above mean high water spring tide (MHW Spring)

Lowland with significant residential or commercial development

Low land protected from inundation by a dike or levee

Extensive, large sand dunes

Beach exposed to the open sea

Beach sheltered from the open sea

Exposed beach with significant residential or commercial development

Sheltered beach with significant residential or commercial development

Wetland having species intolerant of salt water

Wet land having herbaceous species tolerant of salt water

Wet land composed of mangrove trees

Muddy or rocky intertidal zone

Water protected from the open sea

Water not protected from the open sea

\section{MODELING}

\section{Prior Models}

A large number of models have been constructed for fresh- and saltwater wetlands (Day et al. 1973; Wiegert et al. 1975; Costanza et al. 1983; Mitsch et al. 1982; Costanza and Sklar 1985). However, few of these models incorporate the spatial resolution desired in the present study. Two notable exceptions are recent papers by Browder, Bartley, and Davis (1985) and Sklar, Costanza, and Day (1985) on disintegration and habitat changes in the Louisiana coastal wetlands. No previous models provided both the spatial resolution and the generality required for the present study. 


\section{The SLAMM Model}

Description. Because no previous researchers had developed a satisfactory model, it was necessary for us to develop a simulation model suitable for analyzing the impact of sea level rise on coastal wetlands. The model, called SLAMM (Sea Level Affecting Marshes Model), simulates the long-term change in coastal areas due to rising sea level. The model employs a reasonably straightforward but complex set of decision rules to predict the transfer of map cells from one category to another (Figure 4-8). These rules embody assumptions of linear, average responses. They may not apply in detail for any particular area; however, they are suitable for policy development on a regional basis, providing an estimate of the magnitude of the problems and suggesting the nature of the regional policies needed to mitigate those problems.

Figure $4-8$ summarizes the model. The average elevation for a cell is determined by subtracting the sea level rise for a five-year time step from the previous average elevation for that cell. When the average elevation drops below $3.5 \mathrm{~m}$ above mean sea level, undeveloped and developed upland are transferred to undeveloped and developed lowland, respectively. Developed lowland is considered to be "protected lowland" if it incorporates a protective dike or levee (a characteristic noted in the input data) or if the user has chosen the option of having all developed areas protected automatically. Protected lowlands are not permitted to change by the year 2100 , even under the scenario of the highest projected sea level rise.

Undeveloped lowlands and developed but unprotected lowlands are subject to inundation when the average elevation is less than the mean high water (MHW) during spring tides (MHWS), which is approximated as half-again as high as MHW. An inundated cell becomes "tidal flat" (actually rocky intertidal, but the two are combined) if the coast is rocky. If the cell is adjacent to open water it becomes exposed beach; otherwise, it can become one of three categories: tidal flat if erosion is greater than low (as determined by the average fetch of the adjacent sheltered water); mangrove swamp if the region is tropical (as indicated by the presence of mangroves in the map area); or salt marsh. High and low salt marsh are not distinguished nor are differences in levee versus back-marsh accretion rates where the latter two have been differentiated in the literature; accretion rates from back marsh areas have been employed because levee marshes occupy relatively small areas.

The average elevation of wetlands is a function of relative sea level and accretion due to sedimentation and accumulation of organic material. As a simplification, accretion is considered to be an approximate function of the areal extent of existing wetlands; extensive wetlands are considered to indicate high sedimentation and accretion rates (Table 4-5). The influence of this assumption has been tested for several locations and is described in the Results section. When the average elevation of a marsh is less than the level of the embayed MHWS tide plus $0.25 \mathrm{~m}$, the wetland is considered to be saltwater; otherwise it is considered freshwater. (The embayed tide is taken from the source map or, if unavailable, is estimated to be two-thirds the oceanic tidal range; it is assumed that tidal ranges that are amplified by embayments will be noted on the map.) Because freshwater and salt marshes cannot be distinguished using topographic maps, this algorithm is applied to the input data as well as being used during the simulation. However, if the cell is initially freshwater marsh and is protected by a dike or levee, the cell remains freshwater marsh regardless of its elevation. In some areas (especially southern Florida and Louisiana), the extent of freshwater marshes may be underestimated significantly because the influence of freshwater discharge and a coastal freshwater lens is not considered. If the area is tropical, the saltwater wetland is considered to be mangrove swamp; otherwise, it is considered to be salt marsh. Table 4-6 illustrates accretion and subsidence rates for the study areas.

If a salt marsh is adjacent to open ocean or if erosion is heavy (as indicated by the average fetch) or if the average elevation is below mean sea level, the cell is converted to tidal flat. If the average elevation is less than embayed mean low water (MLW) and the marsh is adjacent to water, or if the average elevation is below MLW (which is assumed to be lower than embayed MLW) 
SLAMM FLOW CHART SHOWING TRANSFERS AMONG CATEGORIES

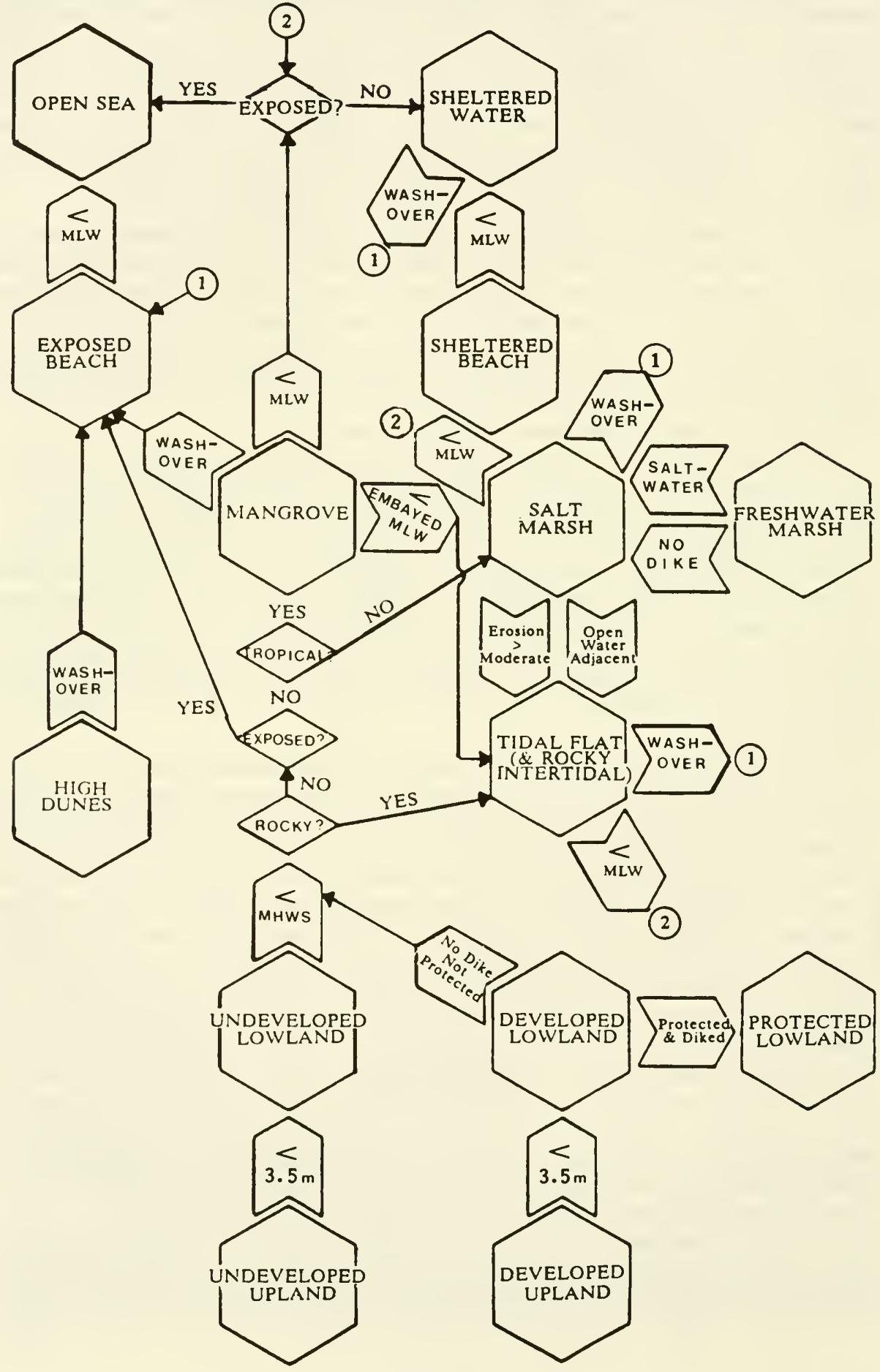


Process

Sea Level Rise

low

high

\section{Accretion of Wetlands}

low

moderate

high

Sedimentation

nondeltaic

deltaic

$\underline{\text { Erosion }}$

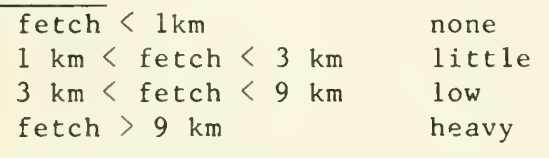

Comments

\section{$1.444 \mathrm{~m}$ by 2100}

$2.166 \mathrm{~m}$ by 2100

$$
\begin{array}{r}
2 \mathrm{~mm} / \mathrm{yr} \\
5 \mathrm{~mm} / \mathrm{yr} \\
10 \mathrm{~mm} / \mathrm{yr}
\end{array}
$$

half of accretion same as accretion
See Chapter 1

See Chapter 1
Low value reported

Common midrange

Approx. highest value observed

cf. Bartberger 1976

cf. Delaune et al. 1983 calibrated and

personal observation

without water adjacent to it), the cell becomes open or sheltered water, depending on its exposure. This algorithm permits the gradual erosion of the edge of an extensive marsh until such time as the entire marsh is inundated. By testing for adjacent water only in the direction of dominant waves for 7 out of 8 cycles ( 35 out of 40 years), the protection afforded wetlands in the lee of obstructions is modeled reasonably well. As more water occurs in the map area, the qualitative erosion rate increases, mimicking the lateral scour due to increased fetch that has been obsened in deteriorating wetlands (Baumann, Day, and Miller 1984).

Mangrove swamp is treated in much the same way as salt marsh except that it can occur on exposed coasts. If the average elevation is less than embayed MLW and there is adjacent water, the cell becomes tidal flat. If the average elevation is less than MLW, the cell becomes open sea or sheltered water, depending on its exposure.

If a cell is tidal flat, its average elevation is a result of sea level rise and sedimentation. If the cell is protected by a dike, it does not change. Otherwise, when the elevation is less than embayed MLW, the cell becomes sheltered water (which can convert to open sea if there is adjacent open sea). If the average elevation is above mean sea level, if erosion is not heavy, and if the coast is not rocky, the cell becomes mangrove swamp or salt marsh.

Undeveloped sheltered beaches become tidal flats if the average elevation is below mean sea level but above embayed MLW; if the average elevation is below embayed MLW, these beaches become sheltered water. If there is essentially no erosion (due to lack of fetch for waves), a sheltered beach is converted to tidal flat. Exposed beaches become open sea when the average elevation becomes less than mean sea level. Developed beaches are treated the same as undeveloped beaches unless they are protected by dikes or the user has chosen the option of protecting all developed areas. It is assumed that fast-rising sea level will not result in significant new dune fields. High dunes become beach when the average elevation becomes less than MHWS. 


\begin{tabular}{|c|c|c|c|c|c|c|}
\hline Location & 1975 & Accret is & $\frac{\text { on Rate (m }}{2050}$ & $\frac{n / y r) \text { a/ }}{2075}$ & 2100 & $\begin{array}{l}\text { Subs idence } \\
(\mathrm{mm} / \mathrm{yr})\end{array}$ \\
\hline Maine Coast $\mathrm{N}$ & 2 & - & - & - & - & 0 \\
\hline Maine Coast $\mathrm{S}$ & 2 & - & - & - & - & 0 \\
\hline New Hampshire Coast & 5 & - & $2(5)$ & 2 & - & 0 \\
\hline Massachusetts Coast & 2 & - & - & - & - & 0 \\
\hline Cape Cod N & 2 & - & - & - & - & 0 \\
\hline Cape Cod S & 2 & - & - & - & - & 0 \\
\hline Narraganset $t$ & 2 & - & - & - & - & 0 \\
\hline Long Is land Sound $\mathrm{CN}$ & 2 & $5(2)$ & 5 & - & - & 0 \\
\hline E. Hampton, NY & 2 & - & - & - & - & 0 \\
\hline Gardiner's Is land, NY & 2 & - & - & - & - & 0 \\
\hline Long Is land $W, N Y$ & 5 & - & - & - & - & 0 \\
\hline At lantic City, NJ b/ & 5 & - & $10(5)$ & 10 & $2(10)$ & 1.2 \\
\hline Tuckerton, NJ b/ & 5 & - & - & $2(5)$ & 2 & 1.2 \\
\hline Delaware Bay, $\bar{R} I$ & 5 & - & - & - & 10 & 2.9 \\
\hline Cape Henloper, DE & 5 & - & - & - & $2(5)$ & 3.0 \\
\hline Chesapeake E., MD & 2 & - & - & - & - & 2.0 \\
\hline Chesapeake W., MD & 2 & - & - & - & - & 2.2 \\
\hline Potomac River E., VA & 2 & - & - & - & - & 1.8 \\
\hline Potomac River $W .$, MD & 2 & - & - & - & - & 1.6 \\
\hline Chincoteague, VA b/ & 5 & - & - & $2(5)$ & 2 & 1.9 \\
\hline Delmarva, VA & 5 & - & - & 5 & $2(5)$ & 1.2 \\
\hline Chesapeake Bay S., VA & 2 & - & - & - & - & 2.8 \\
\hline Roanoke Is land, NC b/ & 5 & - & $2(5)$ & 2 & 1 & 1.2 \\
\hline Albemarle E., NC & 10 & - & - & 10 & 5 & 0 \\
\hline Albemarle W., NC & 5 & - & - & 5 & $2(5)$ & 0 \\
\hline N. Charleston, SC & 5 & - & - & - & 5 & 1.2 \\
\hline Charleston, SC $\underline{b} /$ & 2.5 & $.62(2.5)$ & $.02(.08)$ & $5(0)$ & 2.5 & 1.2 \\
\hline Sape lo Sound, $F \bar{L}$ & 10 & - & - & - & - & 0 \\
\hline Matanzas, FL & 5 & - & - & - & - & 0 \\
\hline Florida Keys & 10 & - & - & 10 & $2(10)$ & 0 \\
\hline 10,000 Is lands, FL & 10 & - & - & - & - & 0 \\
\hline Cntrl. Barrier Coast, FL & 2 & - & - & - & - & 0 \\
\hline Drowned Karst, FL & 10 & - & - & - & - & 0 \\
\hline Apalachicola N., FL & 10 & - & - & - & - & 0 \\
\hline Apalachicola S., FL & 10 & - & - & - & - & 0 \\
\hline Fort Walton, FL & 2 & - & - & - & - & 0 \\
\hline Barataria Bay N., LA & 10 & $5(10)$ & $2(5)$ & 2 & - & 11.0 \\
\hline Barataraia Bay S., LA & 10 & - & $2(10)$ & 2 & - & 11.0 \\
\hline Central Islands N., LA b/ & 10 & - & - & - & $5(10)$ & 4.0 \\
\hline Central Islands S., LA b/ & 10 & - & - & - & $5(10)$ & 4.0 \\
\hline Atchafalaya N., LA b/ & 0 & - & 25 & $1(2.5)$ & 1 & 3.5 \\
\hline Atchafalaya S., LA $\underline{b} /$ & 5 & - & - & $1(2.5)$ & 1 & 3.5 \\
\hline Chenier Plain N., TX & 2 & - & $5(2)$ & 5 & $5(2)$ & 3.5 \\
\hline Chenier Plain S., TX & 10 & - & - & - & $5(10)$ & 3.5 \\
\hline Aransas NWR N., TX & 2 & - & - & - & - & 3.5 \\
\hline Aransas NWR S., TX & 5 & - & - & 2 & - & 3.5 \\
\hline Texas Barrier Is land & 2 & - & - & - & - & 0 \\
\hline Imperial Beach, CA & 2 & - & - & - & - & 0 \\
\hline Del Mar, CA & 2 & - & - & - & - & 0 \\
\hline Oxnard, CA & 2 & - & - & - & - & 0 \\
\hline St. Ynez, CA & 2 & - & - & - & - & 0 \\
\hline SF Bay N., CA & 10 & $5(10)$ & 10 & - & - & 0 \\
\hline SF Bay $S ., C A$ b/ & 2 & $5(2)$ & 5 & - & - & 0 \\
\hline Coos Bay, OR $\underline{\mathrm{b}} /$ & 2 & - & - & - & - & 0 \\
\hline Gray's Harbor, WA b/ & 2 & - & - & - & - & 0 \\
\hline Puget Sound N., WA & 2 & $5(2)$ & 5 & - & - & 0 \\
\hline Puget Sound S., WA & 2 & - & - & - & - & 0 \\
\hline
\end{tabular}

a/ Values in () are for low sea level rise; one value only indicates that the low and high values are the same. A dash means no change. 
Tidal flats, marshes, mangrove swamps, sheltered beaches, high dunes, and sheltered water can become exposed beaches by the process of "washover." If an adjacent exposed beach in the direction of the dominant waves is converted to water or tidal flat, the cell in question becomes beach, with an average elevation slightly above sea level to insure that the beach is not immediately inundated and eroded. This mimics the in-place "drowning" of barrier beaches (Leatherman 1983) and their eventual stepwise retreat over back-barrier marshes and lagoons once they are low enough to be subject to washover (Sanders and Kumar 1975, Rampino and Sanders 1980, Buttner 1981). Washover leads to a migrating beach in seven out of eight cycles; inundation during the other cycle results in a breach in the barrier island.

Each cell category is represented by a pattern and a color, so that the primary output from the model is colored maps for user-specified intervals of years for a given area and rate of rise in sea level. Summary statistics for all categories are provided for 25-year intervals and for wetlands for 5-year intervals so that the progressive impact on coastal wetlands can be assessed.

Assumptions and Simplifications. Because the model is intended to be used for regional analysis of long-term trends, several simplifying assumptions have been made that may not be appropriate for detailed analysis of local and short-term conditions:

- Each square-kilometer cell is represented by only one (dominant) category and by average elevation; this results in pocket beaches and marshes and narrow barrier beaches being under-represented; furthermore, gradual changes seem to occur instantaneously when the threshold average elevation of the cell is reached;

- Continued residential and commercial development of coastal zones is ignored; only those areas developed when the maps were published are subject to protection; given current trends and policies, this may not be a reasonable assumption;

- Freshwater discharge is ignored in distinguishing freshwater from saltwater wetlands; this is most noticeable in the Florida Everglades, which are modeled as mangrove swamp due to their elevation near sea level;

- Sedimentation and accretion rates are related to the extent of existing wetlands; in most areas this results in a decrease in sedimentation as marshes disappear, coinciding with the decrease brought about by sediments "hanging up" further inland in the deepening estuaries; however, in areas where extensive lowlands are inundated and converted into wetlands, this algorithm will predict increased sedimentation-perhaps more than is reasonable;

- No distinction is made among East Coast, West Coast, and Gulf Coast marshes; the same algorithms are used for accretion, erosion, and position within the tidal range for all three regions; SLAMM also does not distinguish between mature and new marshes;

- No provision is made for changing vegetation due to global warming trends; in particular, mangroves will not be simulated in more northerly areas where they do not already occur;

- Cliff retreat is not modeled, nor is the increased supply of sediment to the coastal regime due to cliff erosion; this could affect areas such as Cape Cod, Massachusetts, and Oxnard, California;

- Actual bathymetry is not considered nor is the effect of changing bathymetry on wave energy; beach migration is permitted in sheltered water but not in open sea; this seems to be a reasonable simplification for essentially all areas;

- The change in erosion by tidal currents with changing morphometry and bathymetry is not modeled;

- Changes in storm tracks and in the erosive energy of storms concomitant with climatic change are not modeled. 
Although the model is intended for regional forecasts it does not treat effects on subsurface freshwater supplies or storm-surge effects.

Application. The use of the model may be best understood through application to a particular site. Because Tuckerton, New Jersey, was used as a case study (Kana et al. 1988 and Chapter 3 , this report), it is used as an example here. We simulated the change in squarekilometer cells; three representative cells are emphasized in the following discussion. These are shown in Figure 4-9.

The open-ocean and inland tidal ranges of 3 feet and 2 feet were taken directly from the map. The area was not designated as deltaic, although a small delta is adjacent to the area.

Cell A contains part of a barrier island and adjacent bay and open ocean. Because the barrier island is the dominant element, the cell is encoded as "beach," ignoring the fact that water constitutes almost 40 percent of the area. (The portion of the barrier island immediately to the north does not constitute the dominant element in either of two cells, so both cells are encoded as water.) The average elevation of the island in cell A is estimated to be $1.0 \mathrm{~m}$; with a contour interval of 10 feet and only the dunes shown as exceeding 10 feet, the determination of elevation is admittedly imprecise. Furthermore, the elevation of the dominant category is used, rather than the average elevation for the cell; otherwise, a conflict might arise between the category elevation and the cell elevation used in the simulation.

Cell $\mathrm{B}$ is approximately 50 percent marsh and 50 percent developed lowland; it is categorized as marsh. Inspection of the map indicates that this "worst case" occurrence of two equally distributed categories is uncommon. More often cells are dominated by a single category. Furthermore, over large areas, error compensation would be expected. Based on a linear interpolation, the average elevation is assumed to be $0.5 \mathrm{~m}$. It is not possible to tell from the topographic map whether cell B is salt marsh or fresh marsh, but, given the elevation and the tidal range, we assume it would be salt marsh. Although the cell is developed, because it is salt marsh the development is ignored in the simulation (the assumption being that developed marsh is not valuable enough to be protected).

Cell $\mathrm{C}$ is partly developed lowland, partly marsh, and partly undeveloped upland; it is categorized as developed lowland. The elevation varies from near sea level to over 20 feet; it is given as $1.0 \mathrm{~m}$.

We begin the simulation with the year 1975. The datum for mean sea level is $0.00 \mathrm{~m}$. Because the percentage of marsh is greater than 5 percent and less than 25 percent, we assumed that accretion would be at $5 \mathrm{~mm} / \mathrm{yr}$; because the area is not deltaic, we assumed the sedimentation rate to be half that of marsh accretion $(2.5 \mathrm{~mm} / \mathrm{yr})$. The rates were assumed to be half the natural rates, due to engineering projects diverting sediment on rivers. It might have been reasonable to change this default and double the rates.

Based on an interpolation for the high scenario, the initial rate of sea level rise would be 5 $\mathrm{mm} / \mathrm{yr}$; therefore, by 1980 , mean sea level is modeled as $0.03 \mathrm{~m}$ above the datum. This rise has no effect on the distribution of cell categories in the Tuckerton area. In fact, not until 2030, when sea level is close to $0.5 \mathrm{~m}$ above the 1975 datum, is a change observed ( 0.3 percent of the upland, which was originally $4.0 \mathrm{~m}$ in elevation, is converted to lowland). Meanwhile, by 2000 the rate of sea level rise has increased to $10.44 \mathrm{~mm} / \mathrm{yr}$; by 2025 it has increased to $15.72 \mathrm{~mm} / \mathrm{yr}$.

In 2035, due to the position of the spring high water level, the fresh marshes are converted to salt marshes, with mean sea level $0.55 \mathrm{~m}$ above the 1975 datum. In 2060 , with mean sea level at $1.02 \mathrm{~m}$, several changes take place. Undeveloped upland loses 0.1 percent to undeveloped lowland, and 7.3 percent of salt marsh and 0.1 percent of tidal flat are converted to sheltered water. These cells, originally $0.5 \mathrm{~m}$ in elevation, are now inundated even at low tide. With wetlands decreasing to below 5 percent of the map area, accretion of marsh drops to $2.0 \mathrm{~mm} / \mathrm{yr}$ and sedimentation drops to $1.0 \mathrm{~mm} / \mathrm{yr}$, mimicking sedimentation further upstream in estuaries rather than along the coast. 


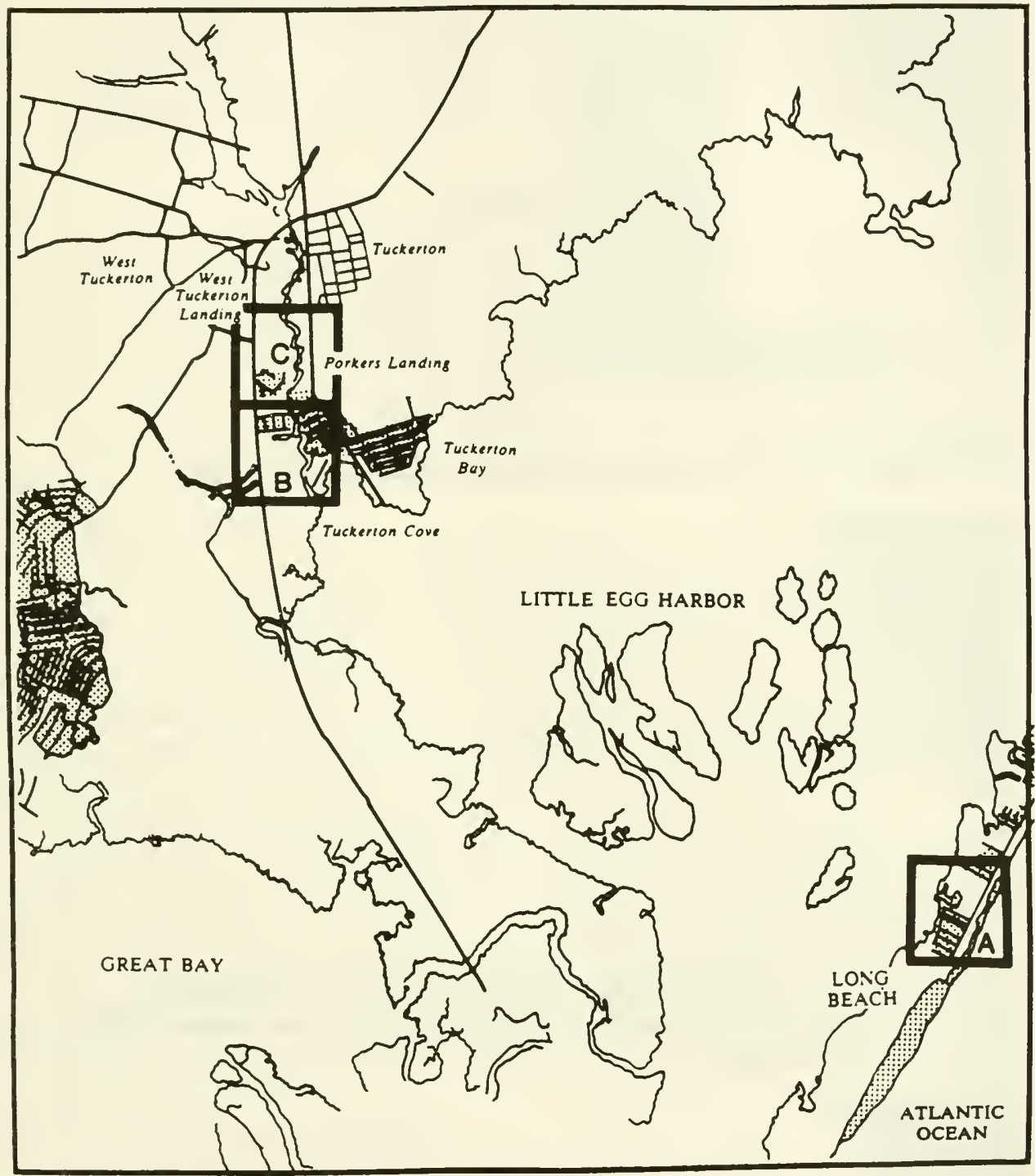

In 2070 another 0.1 percent of salt marsh is converted to sheltered water. In 2080 , with mean sea level $1.53 \mathrm{~m}$ above the 1975 datum, 0.1 percent of undeveloped upland and 0.1 percent of developed upland are converted to undeveloped and developed lowland, respectively; and almost all remaining salt marsh (2.4 percent) and all remaining tidal flat ( 0.4 percent)-cells that were originally $1.0 \mathrm{~m}$ in elevation-are lost to sheltered water. No further changes occur by 2100 (Figures 4-10, 4-11, and 4-12). 


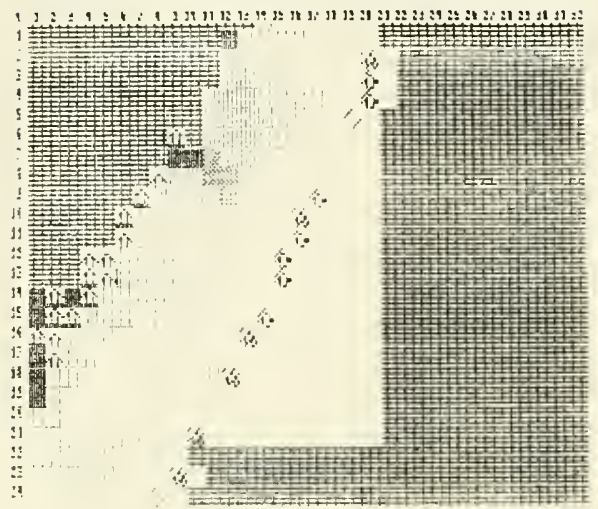

\section{FIGURE 4-11}

TUCKERTON, N.J., IN THE YEAR 2050 WITH HIGH SEA LEVEL RISE

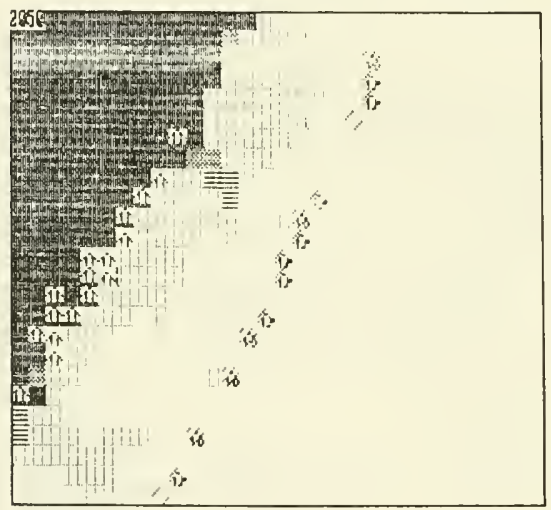

\section{FIGURE 4-12}

TUCKERTON, N.J., AT END OF SIMULATION (Year 2100) WITH HIGH SEA LEVEL RISE, PROTECTION OF DEVELOPED AREAS, AND SUBSIDENCE EQUAL TO $1.2 \mathrm{~mm} / \mathrm{yr}$.

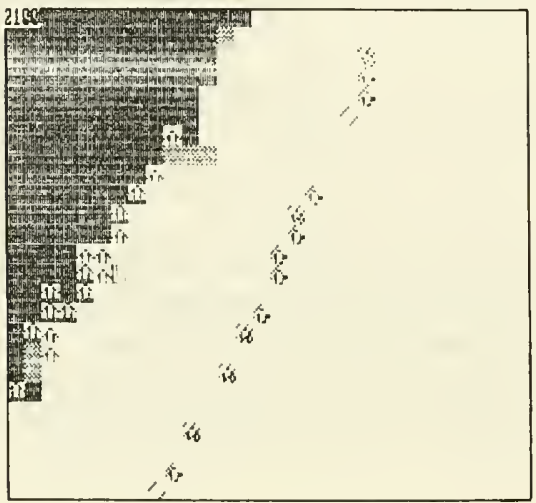

\begin{tabular}{|c|c|c|}
\hline $\begin{array}{l}\text { Undev. Upland } \\
\text { Undev. Lowl and }\end{array}$ & D & $\begin{array}{l}\text { Dev. Upland } \\
\text { Deu. Lowl and }\end{array}$ \\
\hline Prot. Lowl and & $n$ & High Dunes \\
\hline Exp. Beach & , & Shelt. Beach \\
\hline Dev. Exp, Beach & Tp & Dev. She It. B. \\
\hline Fresh Marsh & !ll & Salt Marsh \\
\hline Mangrove & 浖 & Tidal Flat \\
\hline
\end{tabular}


The initial elevation of the exposed beach protected it from inundation. The developed areas were assumed to be protected, so that developed lowland and exposed beaches are not inundated. If the option of not protecting developed areas had been chosen, the pattern would have been quite different: part of the barrier island system would have been breached, resulting in erosion of coastal areas that were previously sheltered from the open sea, and in migration of beaches.

Appendix 4-C describes how to use the program that we used to carry out our simulations. ${ }^{1}$

\section{RESULTS}

In this section the general patterns of the response of wetland regions are summarized for the low and high scenarios. The simulation results are given in detail in Appendices 4-A and 4-B. We show percent change in wetland area from current conditions, rather than absolute area, in order to emphasize that our intent is not to predict expected response at specific locations but to describe one class of response, among several that can be hypothesized, that could develop within a generalized regional coastal environment. Thus, although the text refers to specific map designations, interpretation should be applied only to a general coastal environment similar to the one represented by the designation.

\section{New England Region}

Under the low scenario, the general pattern of salt marsh response in New England involves expansion onto the limited freshwater areas such as those on Cape Cod, or onto unprotected adjacent undeveloped lowland, dunes, or beach. However, where salt marshes with high capacity for lateral erosion are found adjacent to tidal flats immediately landward of open sea, expansion of the flats onto salt marsh also would occur, thus reducing or eliminating existing marshes. (The model may overestimate this effect because attenuation of wave energy is not considered.) This pattern is revealed even by the year 2050 in New Hampshire. These losses, however, are relatively small and/or partially compensated for by expansion of salt marsh onto adjacent freshwater marsh, so that some salt marsh is presenved.

Under the high scenario, however, more rapid rise later would outstrip the adjustment capacity of salt marshes; these would become extensively converted to tidal flats and might be totally lost in some locations where conditions resemble our New Hampshire simulation (Figure 4-13). Even under sheltered conditions, the rise is sufficient to inundate salt marshes in most places with steep slopes and cliffs typical of New England, such as those in Jonesport, Maine, and in Cape Cod, Massachusetts. Thus, for the relatively low accretion rates typical of New England salt marshes and the distribution of land categories found there, a high rate of sea level rise could profoundly reduce the areal distribution of both salt and fresh marshes under conditions stipulated in model simulations.

\section{Mid-and South-Atlantic Region}

Further south from Connecticut to New Jersey, extensive low-lying coastal areas are characteristic. The low scenario predicts salt-marsh distributions similar to the 1975 condition; wetlands could even increase as the intertidal zone encroached onto undeveloped lowlands. Susceptible developed lowlands also might be converted to salt marsh unless protected by dikes. The expansion of salt marsh at the expense of adjacent lowland would already be evident by the year 2050 or before.

${ }^{1}$ The SLAMM program operates on IBM personal computers and is available from the authors. 


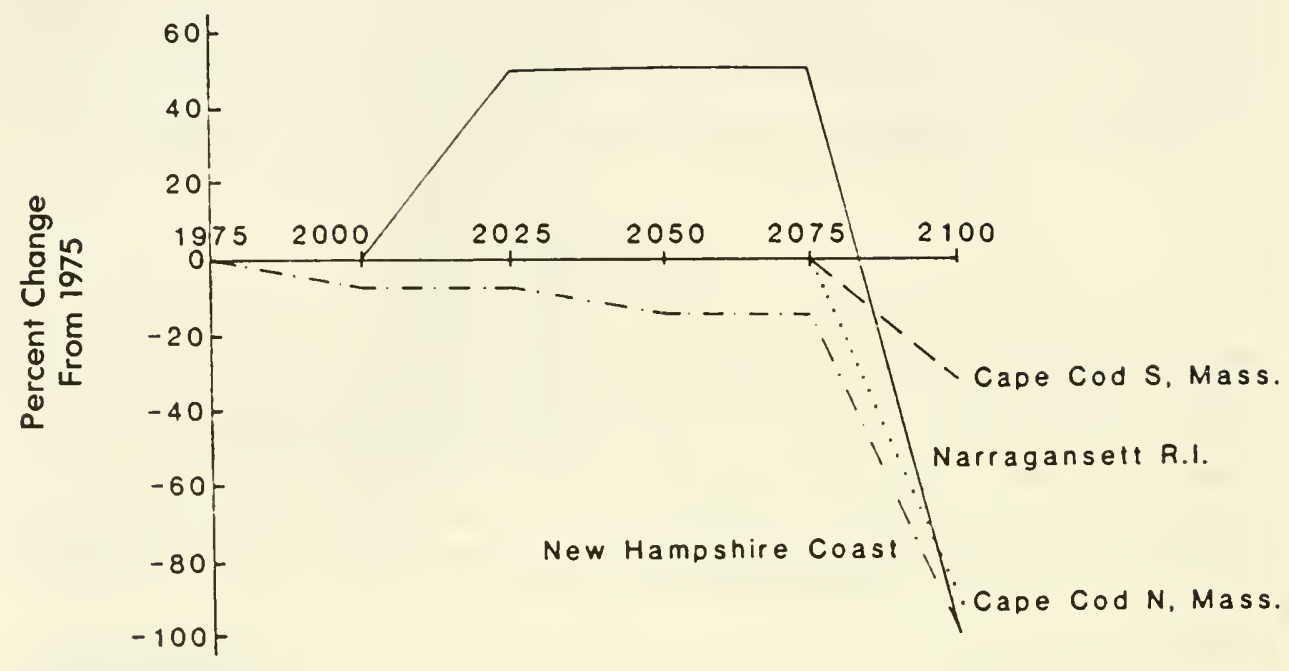

Simulated change in wetland area in New England and mid-Atlantic regions. The high sea level rise scenario is shown. Subsidence is modeled as $0 \mathrm{~mm} / \mathrm{yr}$.

Under the high scenario, salt marsh expansion would accelerate and be more advanced by the year 2050 in certain areas than in the low scenario; but the increased flooding in later decades would inundate exposed seaward salt marsh, thus reducing total marsh area, particularly in the more southerly part of the three-state region (Figure 4-14). On Long Island Sound, however, salt marsh might persist without any loss of area even under the high scenario. However, much of the remaining salt marsh should be recognized as recent and perhaps unstabilized salt marsh developed as a consequence of flooding of lowland nonmarsh areas. Much of the original salt marsh would have been lost to shallow water and tidal flats. Thus marsh properties requiring substantial time to develop might not be evident in many of these newly formed marshes.

In the Maryland-to-Virginia region, a complex pattern of coastal landforms, terraces, and marsh types creates a complex pattern of response. In Delaware, the low scenario reveals the persistence and expansion of marsh as it gains at the expense of undeveloped lowland or fresh marsh until late in the simulation period. But along Chesapeake Bay, where significant subsidence submerges lowland areas and also along parts of the Delmarva Peninsula, tidal flats or sheltered water would replace some salt marsh even by the year 2050. Along the part of Delmarva, Virginia, barrier beaches are breached late in the period, causing the erosion of salt marshes (Figure 4-14).

The high scenario generally predicts acceleration of the processes obsenved under the low scenario. Delaware salt marshes expand through the year 2050 but losses may or may not occur afterward depending on location. At Bombay Hook accretion is projected to rise to $10 \mathrm{~mm} / \mathrm{yr}$, thus reinforcing the maintenance of salt marsh against the sea level rise. At Cape Henlopen lateral erosion increases, causing salt marsh loss. In parts of Virginia, barrier beaches are inundated and breached earlier and salt marsh loss accelerates as these areas decline. Consequently, accretion rate drops, further accelerating salt marsh flooding. Elsewhere (e.g., in Achilles, Virginia) some salt marsh is preserved, even as late as 2100 , partially by the spread of 


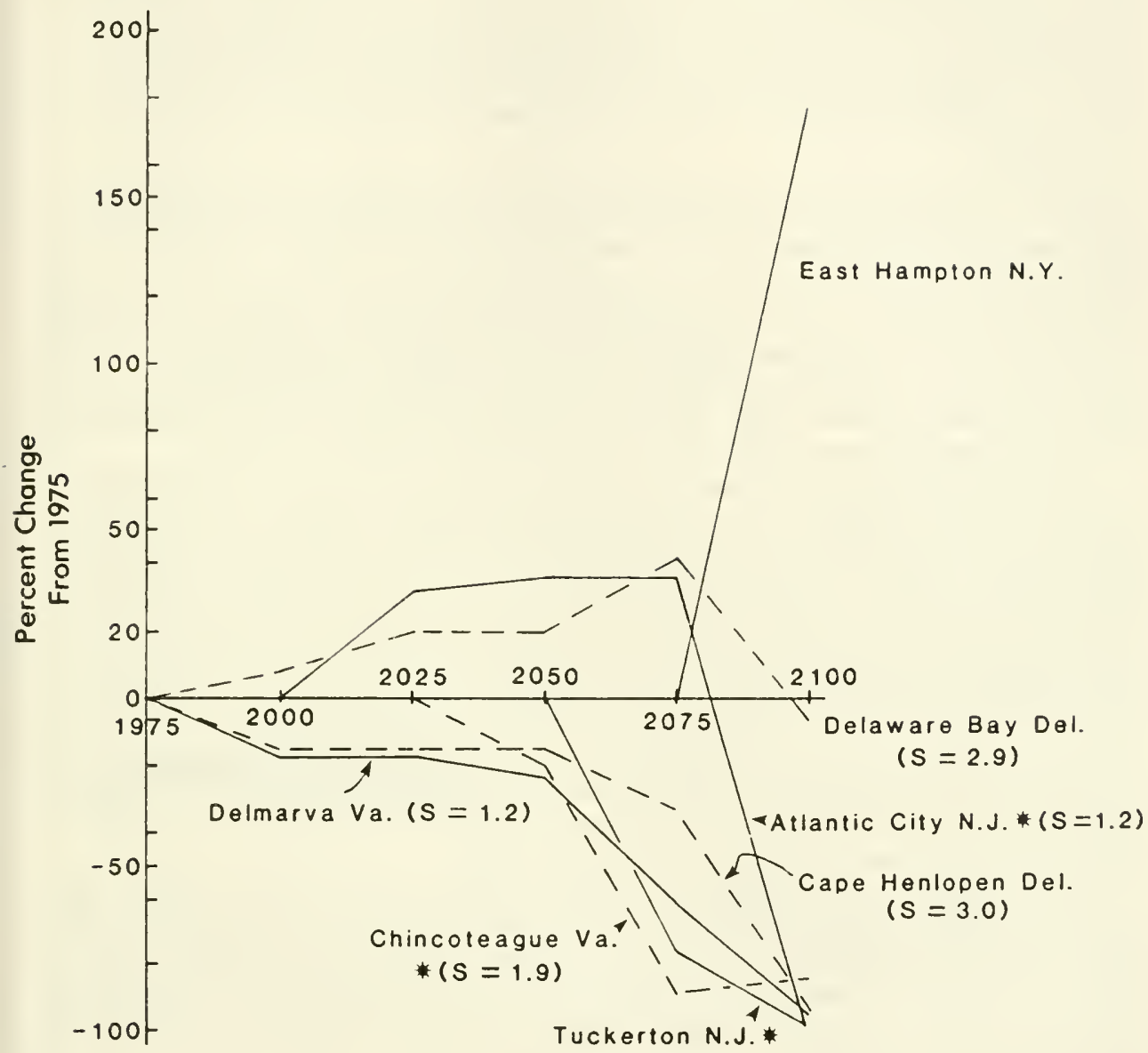

$(S=1.2)$

Change in wetland areas in mid-Atlantic region in SLAMM simulations. The high scenario is shown. Development is protected only on significantly developed sites *. Unless otherwise noted, subsidence (S) is modeled as $0 \mathrm{~mm} / \mathrm{yr}$.

marsh onto adjacent undeveloped lowland late in the simulation period. Overall, however, as expected, a greater net loss of marsh occurs than under the low scenario.

In North Carolina, particularly in and around Albemarle Sound, the abundant marshes would benefit from sea level rise in the low scenario by spreading onto the extensive low terrace (undeveloped lowland) in the first half of the twenty-first century. Thereafter, however, changes vary more clearly with location. At Manteo, for example, wetlands would be completely lost after the year 2075 as seaward wetlands were inundated and landward wetlands were unable to spread to adjacent lowland. Although the high dunes persist through the year 2100 , the wetlands behind them are flooded as are those on the inner edge of the Sound. Only part of this loss can be attributed to a stipulated decline in accretion rate from $5 \mathrm{~mm} / \mathrm{yr}$ to $2 \mathrm{~mm} / \mathrm{yr}$ in 2100 , because the decline began around 2080 before accretion slowed. 
Elsewhere on the Sound (e.g., Columbia), however, wetlands continue to expand, under the low scenario, through the end of the simulation period. In contrast, at Plymouth on the west end of the Sound, wetlands are rapidly replaced by sheltered water over the period 2075 to 2100 . The difference in behavior at the two sites is related to the presence of adjacent lowland. At Plymouth most wetlands are located adjacent to uplands (higher terraces), whereas further east at Columbia, wetlands are located adjacent to undeveloped lowland (low terrace) which can be readily converted to wetlands as mean sea level rises, thus compensating for some wetland loss to sheltered water.

Even under the high scenario, migration of wetlands onto adjacent undeveloped lowland continues as late as 2075 at such sites as Columbia where abundant lowland is available (Figure 4-15). However, after that period, under the assumption that accretion rates declined to $5 \mathrm{~mm} / \mathrm{yr}$ between 2075 and 2100 , wetland area is significantly reduced as rising seas flood out most lowland sites throughout the area. Elsewhere, where less lowland is available, the wetlands maintain themselves at about the same level as under the low scenario until about 2050 . In the second half of the century, however, major losses occur as favorable landward sites for marsh migration become rare. For example, all of the wetlands on Manteo Island are lost to rising seas because no adjacent lowland remains, thus cutting off possible wetland migration.

Wetland behavior at the Charleston, South Carolina, site may not be well simulated by SLAMM because of fine-scale natural and disturbed landscape features that could not be depicted at the scale employed in this study. Charleston harbor is unusual in that the Santee River was diverted into it, causing high sedimentation. In order to maintain this naval port, large amounts of sediments are dredged annually and dumped on the adjacent lowlands. Examination of large-scale maps shows that levees, sea walls, dredge spoil islands, and other alterations of the natural landscape would significantly limit marsh migration. However, because these features are under-represented at the $1 \mathrm{~km}^{2}$ cell scale, our simulations depict higher marsh migration rates than those estimated by fine-scale studies (Kana, Baca, and Williams 1986 and Chapter 2, this report). Under the high scenario, 75 percent of the existing marshes are lost, but 38 percent of the lowland is converted to marsh. Thus, because the model was developed as a regional-scale model, it is of limited use in simulating small-scale patterns.

Marsh behavior in the Georgia environment resembles that of North Carolina. High accretion rates $(10 \mathrm{~mm} / \mathrm{yr})$ enable extensive marshlands to maintain themselves against the rising sea level. The protected marshes on the lee side of undeveloped lowlands can expand onto these lowlands in a seaward movement as well as spread landward onto lowlands further west within the sample area. Elsewhere, however, lowlands replace salt marsh so that the net change is quite small under the low scenario.

Similarly, under the high scenario, because of available lowland and an accretion rate which equals or exceeds the sea level rise rate the first 50 years of the simulation, salt marshes could expand modestly in area. At lower accretion rates, losses of salt marsh would occur relatively quickly under the high scenario. Given that the rate of sea level rise by 2100 exceeds even the high accretion rate by over three times, running the scenario into later years would result in a substantial net loss of salt marsh.

\section{Florida Atlantic and Gulf Coasts}

Although the northeastern part of this region is considered part of the South Atlantic region, it is included here because mangroves could become important if the climate warms.

In north Florida (Matanzas), wetlands are lost by the year 2100 under either low or high sea level rise scenarios, probably reflecting the $5 \mathrm{~mm} / \mathrm{yr}$ accretion rates that are reasonable for this area. Most of the more extensive freshwater marshes here would be lost, but some protected by upland areas would be preserved. 


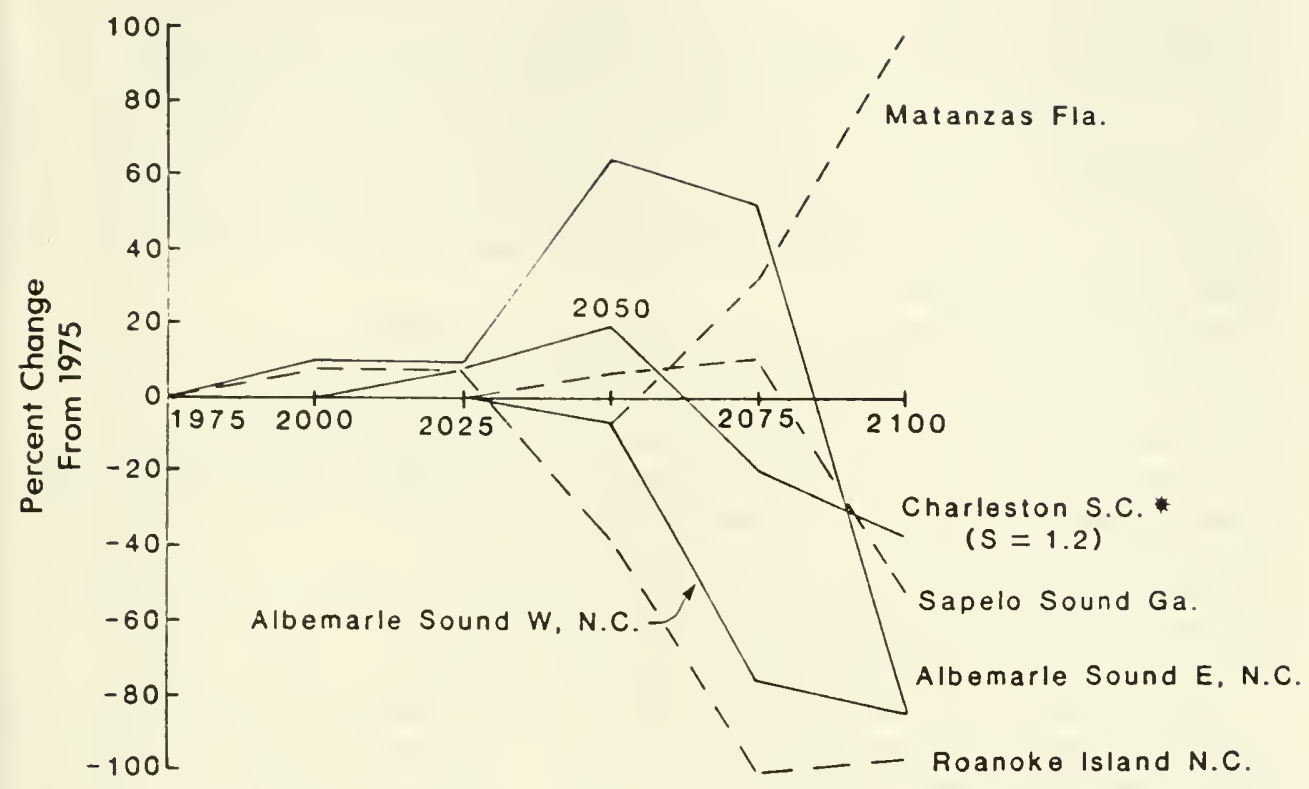

\section{SOUTHERN FLORIDA REGION}

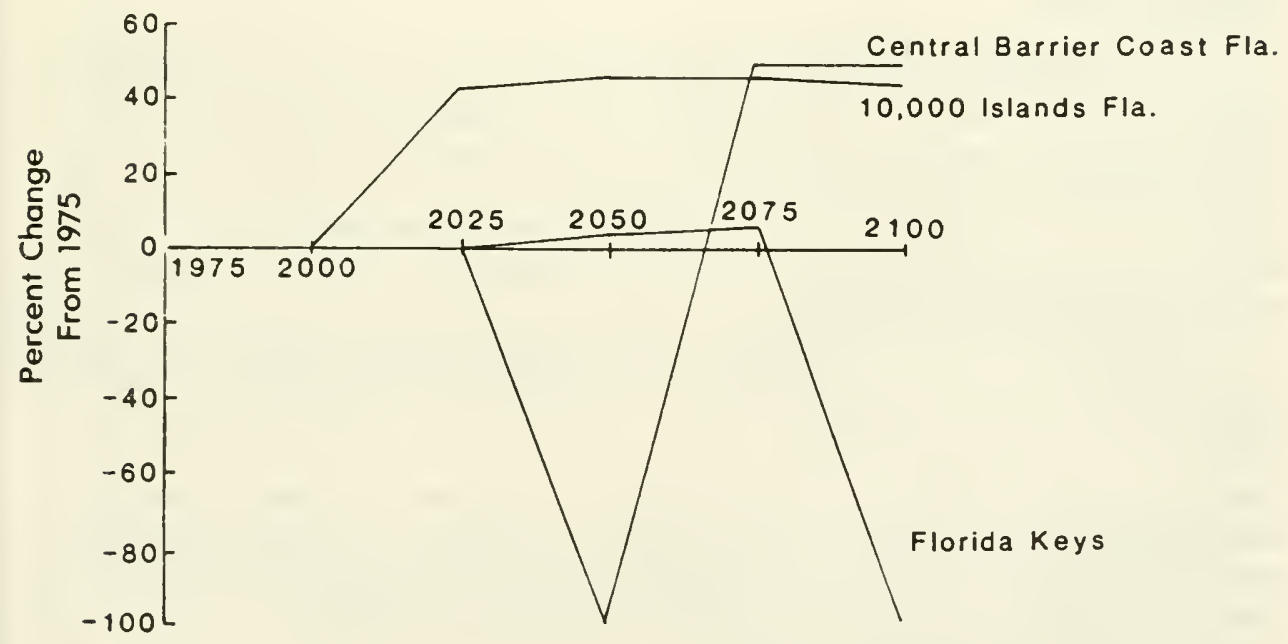

Changes in wetland area in the South Atlantic and southern Florida regions in SLAMM simulations. The high scenario is shown. Unless otherwise noted, subsidence (S) is $0 \mathrm{~mm} / \mathrm{yr}$. 
More interesting, however, is the potential for mangroves to expand into the area, replacing undeveloped and developed lowland. Although the northern limit of mangrove distribution in eastern Florida is about $80 \mathrm{~km}$ south of the Matanzas area, the mangroves here are poorly developed (Odum et al. 1982). The climatic warming that would generate increased sea level rise also would provide favorable conditions for mangrove expansion beyond the center of species distribution in the United States. Because mangrove swamps are modeled as resistant to lateral erosion, a simulation of the area with mangroves is quite different from one with just marsh.

The potential for mangrove expansion is seen more clearly in the response of the 10,000 Islands region of south Florida. Here, under both scenarios through the late twenty-first century, mangroves could become dominant land categories as they moved inland with the advancing tide, replacing marsh and lowlands.

In the Florida Keys simulations, rapid expansion of mangrove onto areas previously occupied by freshwater marsh in the Everglades is also an artifact of the model. Under the low scenario, the replacement of freshwater marsh by mangrove would not occur until near the end of the simulation period. Before then, limited expansion of mangroves onto undeveloped lowland in the Keys would occur. By 2100, however, the extensive freshwater marsh areas on the mainland adjacent to the Keys are inundated at high tide, assuming no influx of freshwater. Under the high scenario, freshwater marsh areas would be subject to tidal water intrusion and conversion to mangrove swamps by the year 2075 unless significant freshwater discharge would inhibit this trend. However, by the year 2100 mangrove areas would be lost due to complete inundation, and only tidal flats would remain on the higher Keys.

Along the Florida Gulf Coast north of the mangrove zone, wetlands would expand inland under both the low and high scenarios. Substantial marsh would remain even as late as 2100 in the high scenario by virtue of available adjacent lowland. Expansion of salt marsh, however, would peak in the high scenario by about 2075, to be followed by increased submergence on the seaward side, greatly slowing down the net increase in wetland area. Under the low scenario, salt marsh would still be expanding fairly rapidly in the year 2100 .

\section{Mississippi Delta}

The response pattern for all the Louisiana wetland simulations was remarkably similar for Barataria Bay, Atchafalaya Delta, and the Central Isles Derniere in the Terrebonne Delta. High subsidence rates (11 mm/yr for Barataria Bay; Hatton, DeLaune, and Patrick 1933) are not entirely offset by high accretion rates. Rising seas thus accelerate loss of seaward salt marshes and disequilibrium is introduced into the salt marsh system. By the year 2100, and often even before (e.g., in the Atchafalaya by 2060), the extensive gains in salt marshes are totally flooded by rising seas and converted to sheltered or open water. By that time, the extensive freshwater and brackish marshes would be long gone.

Although the pattern under the high scenario was similar, trends developed at a faster rate. By 2050 most salt marshes were totally inundated (Figure 4-16). Elsewhere the process was a bit slower but the trends were similar. In those cases complete loss of salt marsh was apparent by the year 2075 in the high scenario (Figure 4-16). These rapid losses occurred despite a simulated accretion rate of $10 \mathrm{~mm} / \mathrm{yr}$ in marshes. The loss rate of salt marshes in the later decades of each scenario can be attributed partly to a lower accretion rate which can be expected as estuarine conditions prevail. However, even with a constant rate of $10 \mathrm{~mm} / \mathrm{yr}$, rapid losses of wetlands in coastal Louisiana would result from accelerated sea level rise, as simulated.

\section{Chenier Plain-Texas Barrier Islands}

In the sample area considered on the Chenier Plain of Texas, extensive freshwater marshes lie behind lowlands which include small salt marsh areas. Under the low sea level rise scenario, the seafront salt marshes are largely lost to tidal flats by the year 2000 , but inland marshes are unaffected. However, in succeeding decades, salt marsh expands onto adjacent freshwater marsh, 
At some sites marshes would expand significantly by the year 2050, spreading onto adjacent undeveloped lowland (Figure 4-17). Generally, however, by the end of the simulation period, these gains have been lost where barrier islands that protect marshes have been breached, or have washed over onto the back-barrier marshes. Most of these regions have become open sea by this time. Yet elsewhere, where tidal fluxes are dampened as in the Chenier Plain North sample area, salt marshes continue to expand through the end of the twenty-first century. In such protected situations, the full effects of sea level rise are delayed relative to more exposed situations.

\section{FIGURE 4.17}

\section{CHENIER PLAIN-TEXAS BARRIER ISLANDS}

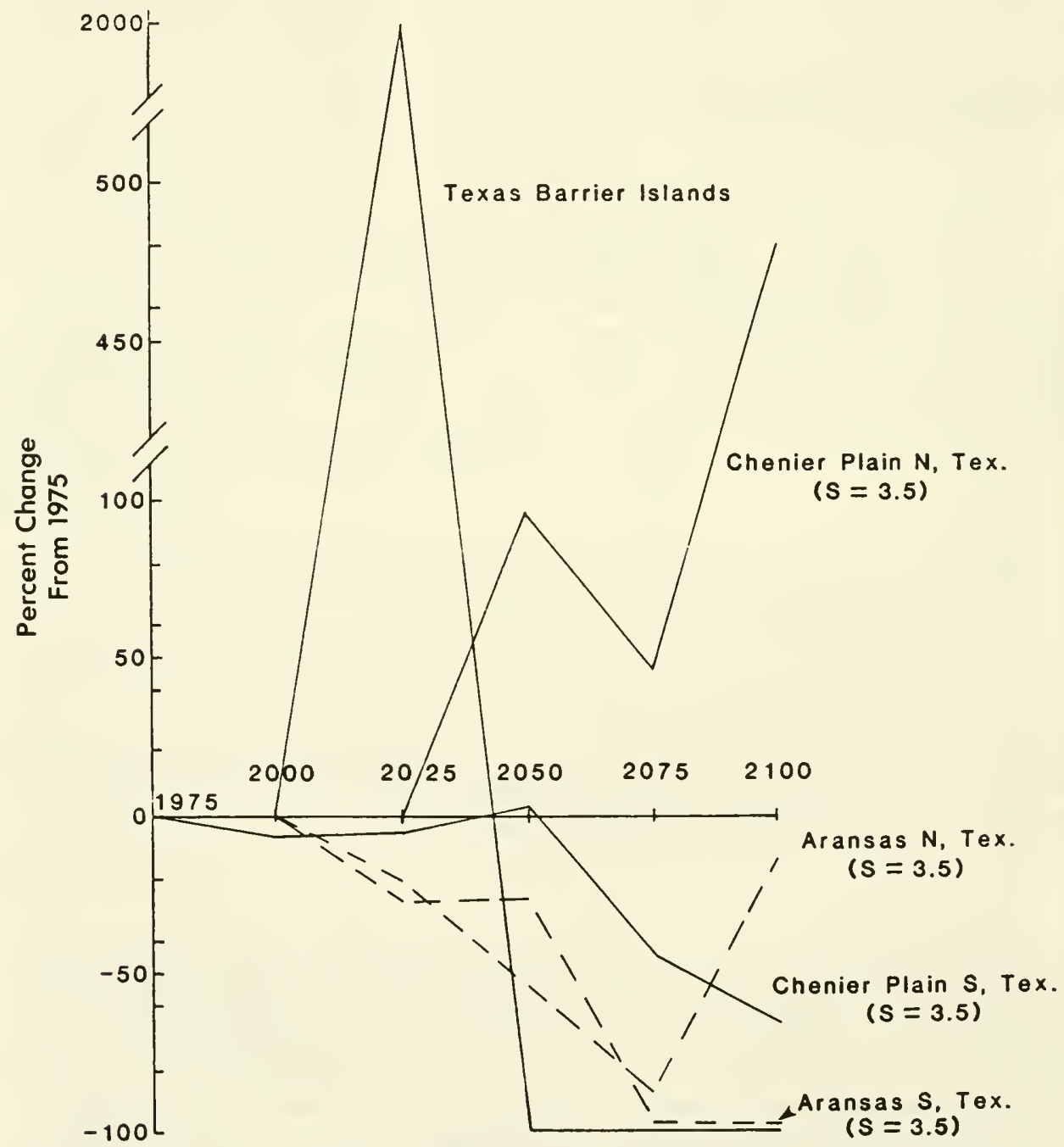

Changes in wetland area in Texan study sites according to, SLAMM high-scenario simulations. Unless otherwise noted, subsidence (S) is $0 \mathrm{~mm} / \mathrm{yr}$. 


\section{Californian Region}

South of San Francisco Bay, most coastal wetlands in California are so small as to be underrepresented at the regional scale used in this study. Thus, at the $1 \mathrm{~km}^{2}$ cell level, no salt marsh appears as a dominant land category except at Oxnard. Here, marsh is lost by the end of the simulation period through formation of tidal flats and eventually total submergence of some cells in both scenarios (Figures 4-18). Elsewhere in southern California, freshwater marshes may persist where they are located in sheltered or protected locations (e.g., Imperial Beach). Salt marsh could persist under both scenarios under unprotected situations (such as Del Mar) so long as adjacent lowland or freshwater marsh could be converted. That the potential for marsh establishment and spread may be limited by abrupt topographic change is seen at Santa Ynez, where no marsh is developed at any time under either scenario.

In San Francisco Bay the presence of large marshlands, many severely modified by human activities, presents a different situation. A large percentage of remaining marshlands in the Bay area has been associated with levees at one time or another and many of these no longer function as typical salt marshes. But the remaining $10-20$ percent of the salt marshes still open to tidal exchange provide a starting point for the expansion of salt marsh onto adjacent lowland and freshwater marsh. However, where any of these areas are protected by levees, salt marsh migration is not possible. Thus, protected marshes may persist while salt marsh expands significantly onto other unprotected lowlands.

Even where accretion is considered to be zero, protection will permit persistence of the marshes. Some losses may occur as a result of rising waters, but this may be offset by marsh migration onto unprotected lowlands. This is seen under the low scenario for both simulations. In the south Bay area, even under the high scenario, salt marshes increase over the entire simulation period, primarily through expansion into lowland areas already near sea level through subsidence due to groundwater withdrawal (Figures 4-18). At the north Bay site, the same situation holds well into the second half of the twenty-first century; but by the end of the simulation period, flooding begins to exceed the continued spread of salt marsh and a net decrease occurs. However, the loss, compared to the 1975 condition, is only about 39 percent of the total marsh area because of the protection afforded by levees.

\section{Columbian Region}

Although coastal topography in the Columbian region limits wetland area and would be expected to do so if sea level rise accelerated, simulations of sites with significant metlands suggest that for low and high sea level rise scenarios, salt marsh area would expand (Figure 4-19). Expansion would be seen both along the coast in bays and harbors as well as under conditions similar to those of the northern and southern ends of Puget Sound. In fact, under both scenarios at all sites examined, salt marsh would begin expanding early in the simulation period and continue for the most part until 2100, even in the high scenario; however, the total areas involved are small. Only under conditions such as those found at Coos Bay would rising seas begin to exceed the spread of salt marsh, and this reversal would develop only in the last quarter of the twenty-first century (Figure 4-19). At that time undeveloped lowland for colonization by salt marsh becomes limited. Elsewhere, where important undeveloped lowland areas remain which could convert to salt marsh, marsh areas continue to expand, sometimes rapidly, as in our simulation of Puget Sound North. Here, in both scenarios, salt marshes are still expanding significantly as of 2100 , but more rapidly in the high scenario because of adjacent undeveloped lowland. However, the more rapid expansion of salt marsh also means more rapid decrease in lowland availability, suggesting that conditions soon would become limiting for further salt marsh expansion here as well. For all our simulations in the Columbian region, wetland areas in the next century would exceed present areas due to the adjacent low terrace; because of the rapid rise in sea level this would not be a continuation of the present tendency of tidal marshes in this region to prograde under twentieth-century conditions (Seliskar and Gallagher 1973). 


\section{CALIFORNIAN REGION}

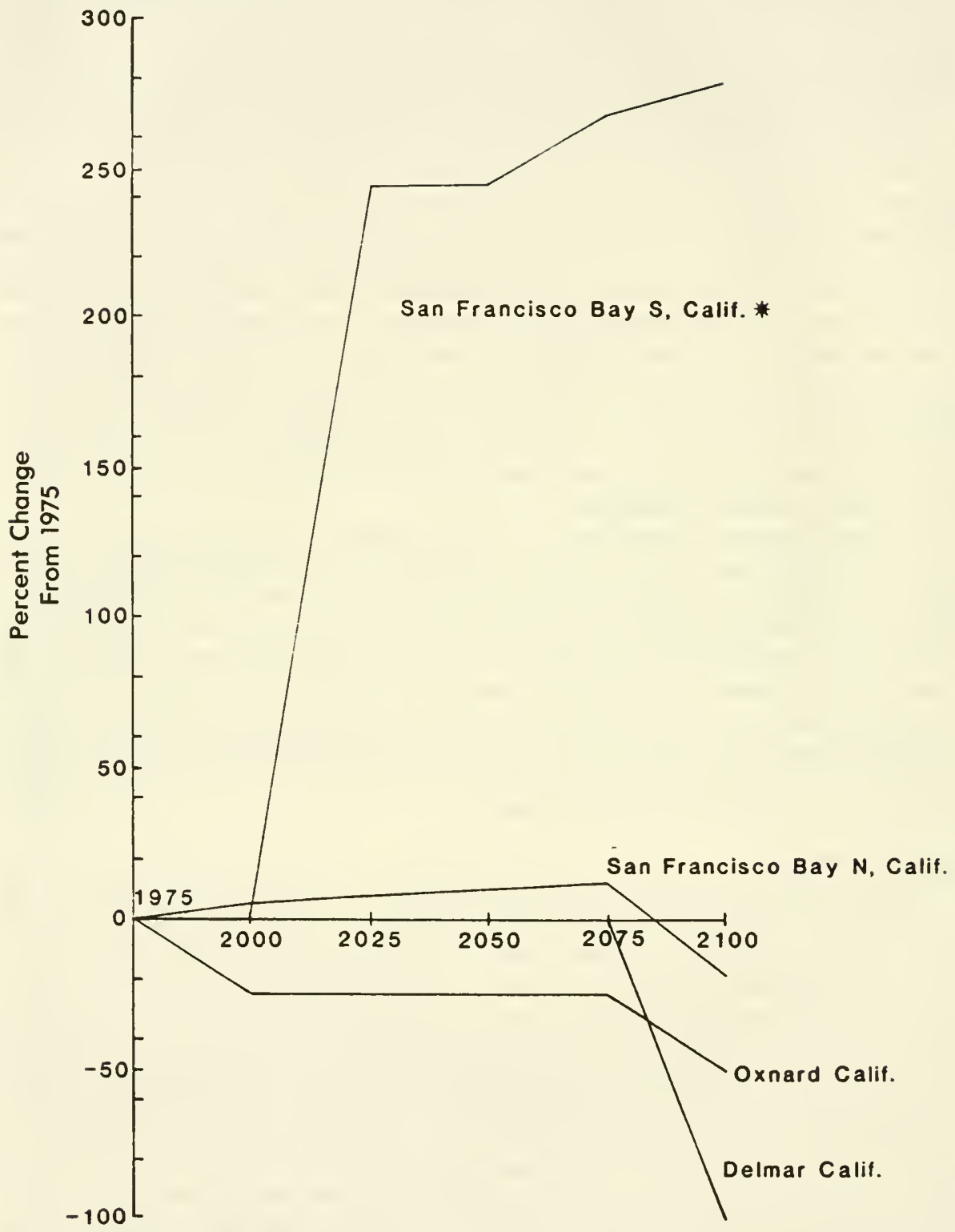

Changes in wetland area in Califomian study sites according to SLAMM high-scenario simulations. Development is protected only on significantly developed sites*. Subsidence is modeled as $0 \mathrm{~mm} / \mathrm{yr}$. 


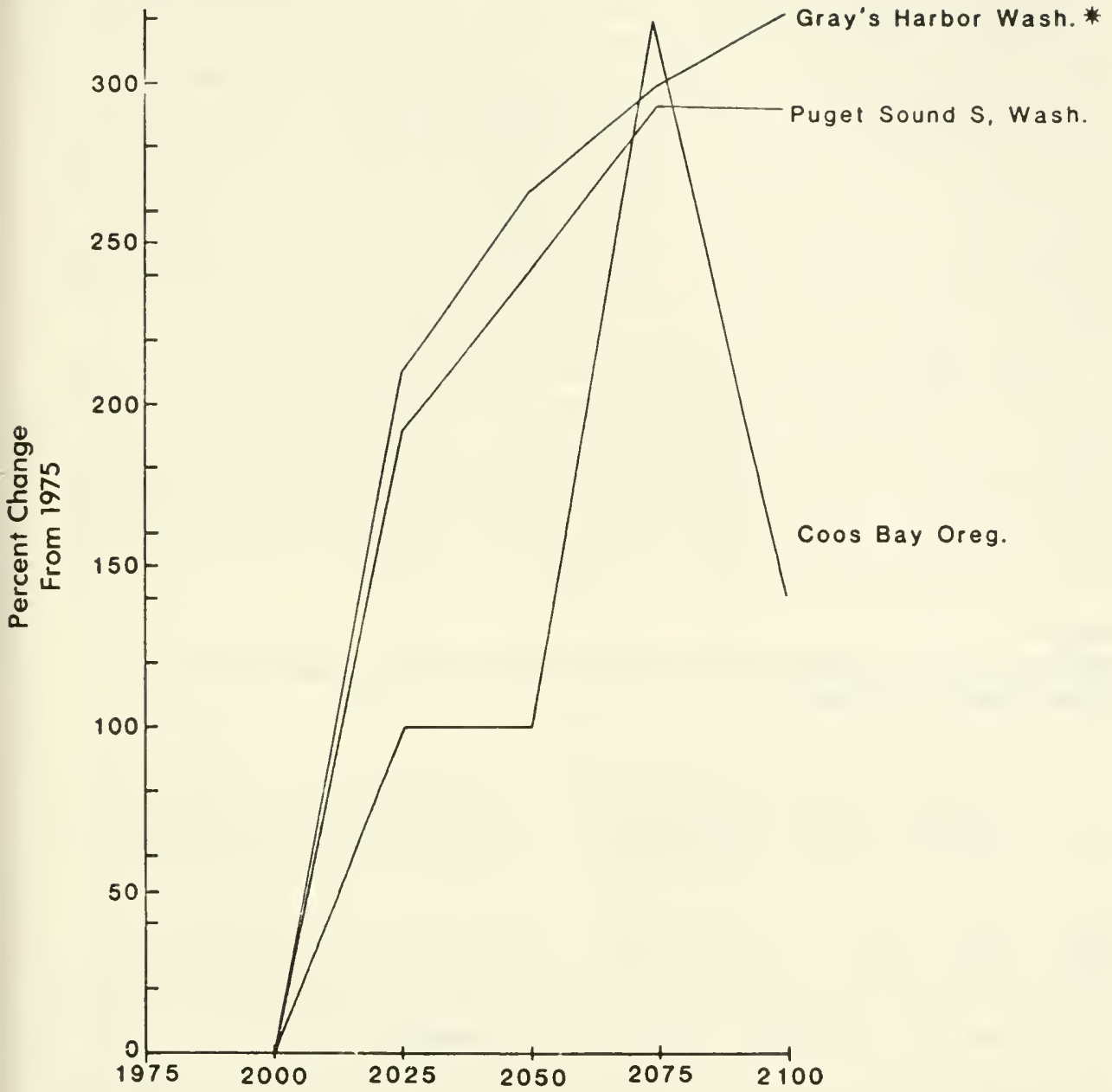

Changes in wetland area in Columbian study sites according to SLAMM high-scenario simulations. Development is protected only on significantly developed sites*. Subsidence is modeled as $0 \mathrm{~mm} / \mathrm{yr}$. 


\section{DISCUSSION}

\section{Effects of Alternate Assumptions}

Geodynamic changes in elevation of land relative to "global" sea level are a function of glacial isostatic rebound affecting large portions of continents, regional adjustments to plate tectonics, subregional isostatic adjustments to sedimentary loading, and local subsidence due to withdrawal of groundwater and oil and compaction of sediments. Because relative sea level at any particular tidal gauge is also affected by barometric pressure, wind direction, and coastal currents, at least 35 years of data are needed to separate the various components of local sea level to detect a $1 \mathrm{~mm} / \mathrm{yr}$ trend with 95 percent confidence (IAPSO 1985). The average rate of glacial isostatic submergence for the East Coast is $0.6 \mathrm{~mm} / \mathrm{yr}$ (IAPSO 1985), which would mean that the simulation would be advanced by approximately three years over a hundred-year period compared with a 0.0 value for subsidence. If a value of $1.2 \mathrm{~mm} / \mathrm{yr}$ is used, based on Hicks et al. (1983), the simulation is advanced by six years over a hundred-year period.

Simulation of sea level response at Bombay Hook, Delaware, shows how subsidence assumptions affect wetland response. If subsidence is considered as negligible (held to 0.0 in computer runs), only a slightly different outcome results by the year 2100 than if subsidence is considered to be $2.9 \mathrm{~mm} / \mathrm{yr}$ (Table 4-7). Under the low scenario, higher subsidence results in a slightly larger wetland area because conversion of lowland occurs. Marsh area expands at the expense of undeveloped lowland by virtue of its $5 \mathrm{~mm} / \mathrm{yr}$ accretion rate beginning around the turn of the century. However, subsidence assumptions make no difference through 2050.

\section{TABLE 4-7}

\section{PERCENT MARSH FOR DIFFERENT MODEL CONDITIONS; DELAWARE BAY: TOTAL AREA $=30,800$ ha}

\begin{tabular}{|c|c|c|c|c|c|c|c|c|}
\hline \multirow[b]{3}{*}{ Year } & \multicolumn{4}{|c|}{ Low } & \multicolumn{4}{|c|}{ High } \\
\hline & \multicolumn{2}{|c|}{$A=5$} & \multicolumn{2}{|c|}{$A=$ Variable } & \multicolumn{2}{|c|}{$A=5$} & \multicolumn{2}{|c|}{$A=$ Variable } \\
\hline & $s=0$ & $0 \quad s=2.9$ & $s=$ & $s=2.9$ & $s=0$ & $s=2.9$ & $s=$ & $s=2.9$ \\
\hline 2050 & 29.2 & 29.2 & 29.2 & 29.2 & 29.2 & 29.2 & 29.2 & 29.2 \\
\hline 2100 & 34.0 & 34.7 & 34.0 & 34.7 & 30.5 & 22.7 & 39.2 & 30.2 \\
\hline
\end{tabular}

$A=$ Accretion Rate in $\mathrm{mm} / \mathrm{yr} ; S=$ Subsidence Rate in $\mathrm{mm} / \mathrm{yr}$

In the Gulf Coast, average subsidence ranges from 0.0 and $1.5 \mathrm{~mm} / \mathrm{yr}$ (Holdahl and Morrison 1974). Subsidence is essentially zero for most of the Gulf Coast areas simulated, except for the northern Texas Coast, where a subsidence value of $3.5 \mathrm{~mm} / \mathrm{yr}$ was used, and for the Mississippi Delta, where values of 3.5 to $11 \mathrm{~mm} /$ year were used. Because the tidal range is $0.3 \mathrm{~m}$ along the Texas Coast, a $3.5 \mathrm{~mm} / \mathrm{yr}$ subsidence doubles the rate of change in coastal features compared to the default of 0.0 . The results of these alternative values are shown in Table 4-8.

As expected, holding accretion rate constant, rather than allowing it to increase as marshes expand, has an impact similar to that of introducing a small subsidence rate (Table 4-7). The net effect is loss of most wetlands that would have been gained under the higher accretion rate by the year 2100 . However, the total wetland area was nearly equal under the two conditions. Differences are more striking under the high scenario. Here the increase in accretion to $10 \mathrm{~mm} / \mathrm{yr}$, which began in 2075, enables salt marsh expansion. In contrast, if the accretion rate is held constant, marsh never accumulates beyond its original area in 2075, and fewer areas are suitable for marsh expansion. Therefore, by the year 2100 the marsh area was reduced to 30.5 percent. In contrast, the total area of wetlands with rising accretion but no subsidence equalled about 39 percent. 


\begin{tabular}{|c|c|c|c|c|c|c|c|}
\hline \multirow[b]{2}{*}{ Region } & \multirow{2}{*}{$\begin{array}{c}1975 \\
\text { Marsh } \\
\text { Area }\end{array}$} & \multicolumn{3}{|c|}{ Low Scenario } & \multicolumn{3}{|c|}{ High Scenario } \\
\hline & & Lost & Gained & Net & Lost & Gained & Net \\
\hline New England & 6.0 & 0.2 & 0 & -0.2 & 3.8 & 0 & -3.8 \\
\hline Mid-Atlantic & 45.4 & 17.7 & 8.9 & -8.8 & 45.5 & 6.7 & -38.8 \\
\hline South Atlantic & 91.3 & 26.1 & 30.2 & 4.1 & 70.5 & 21.2 & -49.3 \\
\hline Florida (subtropical) & 59.8 & 0.2 & 17.4 & 17.2 & 24.1 & 16.0 & -8.1 \\
\hline NE Gulf Coast & 73.6 & 6.4 & 1.3 & -5.1 & 21.6 & 2.4 & -19.2 \\
\hline Mississippi Delta & 150.9 & 121.1 & 0 & -121.1 & 146.0 & 0 & -146.0 \\
\hline Chenier Plain TX & 29.9 & 10.9 & 6.8 & -4.1 & 31.5 & 6.5 & -25.0 \\
\hline Californian Prov. & 26.5 & 9.1 & 8.9 & -0.2 & 9.5 & 10.2 & 4.7 \\
\hline Columbian Prov. & 1.2 & 0.1 & 11.6 & 11.5 & 0.3 & 12.4 & 12.1 \\
\hline TOTAL IN SAMPLE b & 484.6 & 191.8 & 85.1 & -106.7 & 352.8 & 76.4 & -272.4 \\
\hline
\end{tabular}

a/ The projections are not interpretable as statistically valid estimates of regional trends.

$b /$ The number of cells in particular regions were not based on underlying population. Thus, the percent reduction of sample does not necessarily reflect reductions in U.S. wetlands.

When accretion rate is held constant and a subsidence rate of $2.9 \mathrm{~mm} / \mathrm{yr}$ is assumed, conditions are least favorable for maintenance of marshland (Table 4-7). Under the low scenario, total wetland area is reduced to 22.7 percent by the year 2100 , one-third less than without subsidence. Inland marsh would have disappeared by 2100 , but its area is unchanged from assumptions of constant accretion without subsidence through the year 2075. Marsh areas react somewhat similarly under both scenarios, but with subsidence, areas peak by 2075 instead of continuing to expand, and then decline suddenly to the final level as inundation accelerates. Thus the cumulative effect of subsidence becomes most apparent only late in the scenario period.

The importance of accretion rate was examined in the Albemarle Sound East simulations by comparing varying accretion rates with a constant accretion rate of $5 \mathrm{~mm} / \mathrm{yr}$ (Figure 4-20). The high accretion rate allows marshes to be maintained through the year 2050 rather than the year 2000 under a lower accretion rate. By 2050, despite the lower accretion rate, salt marsh initially expands for the next 25 or 30 years. Later, rising waters rapidly inundate the salt marshes, eliminating them completely by the year 2095. In contrast, the $10 \mathrm{~mm} / \mathrm{yr}$ accretion rate allows greater persistence of marshes through the year 2085.

Shortly thereafter, however, the exponentially increasing rise in sea level drowns over 90 percent of the marshes, leaving a situation only marginally improved over conditions prevailing under assumptions of a lower accretion rate. Although the importance of accretion in maintaining marsh elevation against rising seas is seen, an accelerating rise in sea level allows accretion rate to provide only a temporary means for maintaining coastal marshlands. 


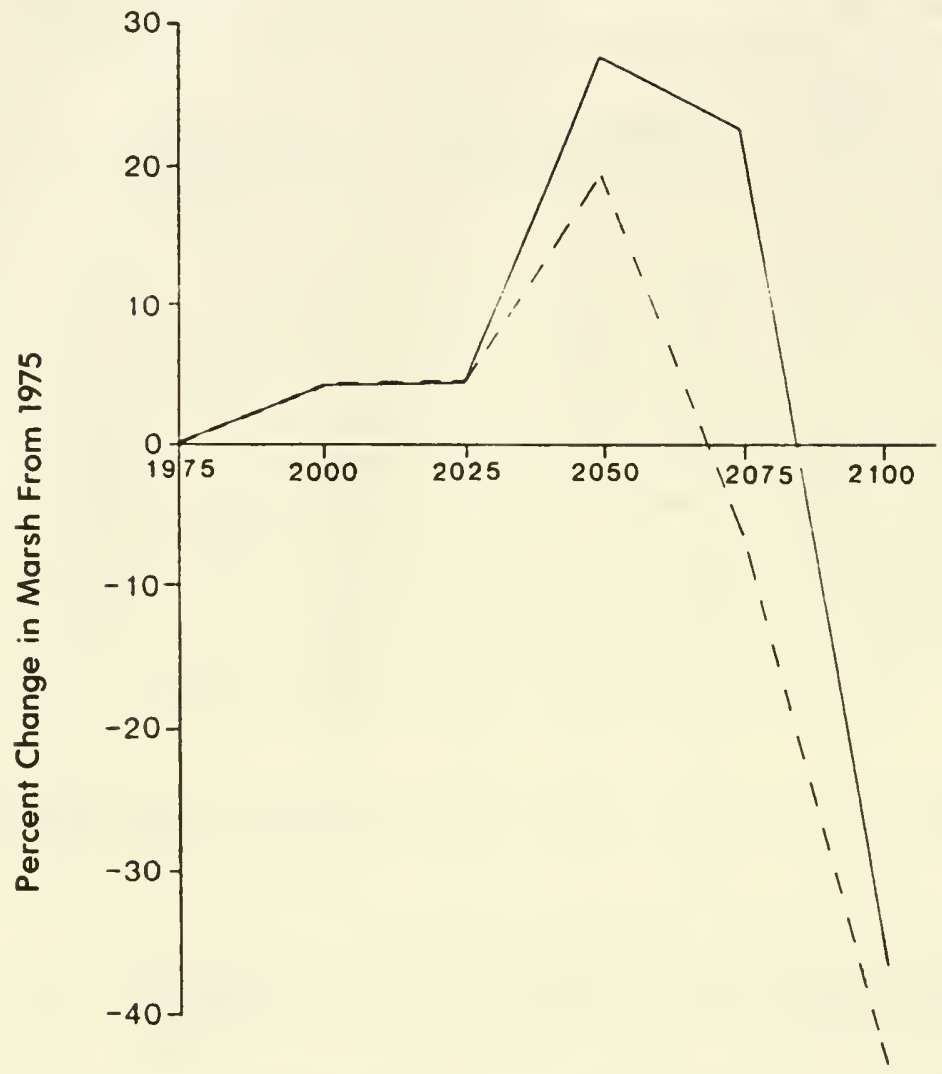

\section{CHARLESTON}

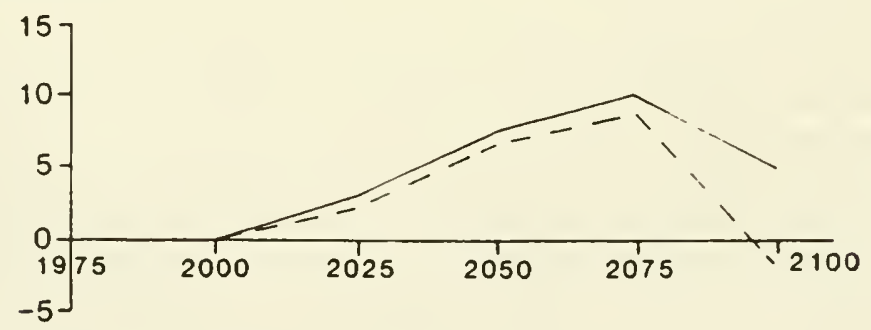

High sea level rise scenario

High accretion: rate allowed to rise

- - - Low accretion: rate not allowed to rise

The effect of altermative accretion-rate assumptions on changes in wetland area at Albemarle Sound East, North Carolina, and Charleston, South Carolina. 


\section{Model Comparisons with Site Assessments}

There are few opportunities for validation of our regional model of coastal response to sea level rise. Knowing that the model has an accuracy definable at a particular level would be of great help in interpreting the findings of the study. One approach to validation, although an imperfect one, is to compare model results with detailed studies of local sites. Two such studies are available-a study of the impact of sea level rise on wetlands in Tuckerton, New Jersey, by Kana et al. (1988 and Chapter 3, this report), and in Charleston, South Carolina, by Kana, Baca, and Williams (1986 and Chapter 2, this report). However, it must be recognized that true validation cannot be obtained because of the radically different approaches being compared. Thus, our simulations for Charleston suggest that a greater capacity for marsh migration exists than fine-scale analysis suggests. As stated above, fine-scale disturbances and landscape complexity, which limit marsh migration, could not be simulated using a square kilometer grid. The New Jersey site, however, with greater landscape homogeneity on a coarser scale, provides a quasivalidation of the SLAMM model.

Several of the major differences in methodology of the regional model and site-specific approaches should be understood before making comparisons. First of all, the model approach operates at a much larger geographic scale and consequent loss of local scale accuracy, in keeping with the major objectives of the study. Thus, for example, high and low salt marsh are not distinguished in the model as they are in the site studies. The $1 \mathrm{~km}^{2}$ cell which forms the spatial unit of the model is defined only by the predominant land category type present. Therefore, in areas where salt marsh may be an important but secondary land category, it will be underrepresented in the regional analysis. Similarly, where salt marsh predominates, it could be overrepresented as the only category present, and if conditions for migration are favorable, an overestimate of migration results. In the comparisons to follow, this latter situation is believed to be more significant than the former.

The data limitations in the modeling approach are defined by the accuracy and timeliness of the USGS 7 and 1/2 minute (and occasionally 15 minute) quadrangle topographic map series. Necessarily, then, a set of generalized properties results. This is most apparent with elevation because the quadrangle series frequently presents elevational contours at five- or ten-foot intervals, which are quite coarse for subdividing coastal land categories. Consequently, subtle differences which show up in a detailed study as a loss or gain of one category or another are not recognized in the regional analysis.

Freshwater and saltwater marshes are not distinguishable based on the USGS maps. Therefore, the raw data recognizes only "marsh," and our model used an algorithm based on elevation with respect to spring high tide to differentiate the two types.

Other aspects affect both regional and local interpretations. These include limited data on subsidence rates and accretion rates as well as on actual marsh migration rates, and lack of any empirical knowledge of coastal land responses to sea level rise at a rate as rapid as that projected for the next century.

The major response at the New Jersey wetland site to the low scenario through 2075 is the replacement of high salt marsh with low salt marsh (Kana et al. 1988 and Chapter 3, this report). Also projected is the loss of over half the transition marsh in the Tuckerton area, but an increase of the same area in the Great Bay Boulevard area. However, at both locations no change in overall wetland area is projected under the low scenario. The conversion of high to low salt marsh noted by Kana et al. would not be detected in our model; furthermore, because the distinction between saltwater and freshwater marsh cannot be made in the input data but is based on imprecise elevation determinations, we prefer to consider total wetland changes. Adjustments to transitional marsh in the New Jersey and South Carolina studies would occur within the framework of our general freshwater marsh category. We project a 9 percent decline in total wetland area by 2075 , growing rapidly to a 75 percent decline by the year 2100 . For the year 
2075 , Kana et al. project a slight increase in the total marsh area, whereas we project a 9 percent decline. However, as late as 2045 we project a 1.0 percent decline in wetland area, a figure not significantly different from theirs given the limits of both studies. Our simulation through the year 2100 , however, suggests that the trend toward migration onto adjacent lowland would soon come to an end and that many of the gains would be lost.

Agreement is more pronounced under the high scenario. Kana et al. project an 86 percent decline in salt marshes of the Tuckerton area by 2075, compared to a loss of 75 percent by 2075 and a loss of 99 percent by 2080 in our study. Consequently, our conclusion with respect to salt marshes in the Tuckerton area is that the two methods, despite being dissimilar in many respects and covering different areas, represent reasonably well an unstable coastal situation which leads to either salt marsh gains or salt marsh losses, depending on rates of sea level rise.

\section{FUTURE RESEARCH NEEDS}

Although the implementation of the SLAMM model has provided a useful analysis of probable coastal wetland responses to accelerated sea level rise, increased accuracy, reliability, and credibility would follow from additional refinement and study. We recommend that the following steps be implemented:

(1) Increase the resolution by using a $0.25 \mathrm{~km}^{2}$ or $0.125 \mathrm{~km}^{2}$ grid cell for most areas. This would avoid the under- or over-representation of categories such as marshes and would permit the elevation of the dominant category to coincide more closely with the average cell elevation. The reliability of results would be significantly increased through these more realistic estimates of the distributions of the major categories.

(2) Obtain statistically unbiased samples of sufficient size for quantitative inferences. To do this, a method for stratified random sampling within each region must be developed which takes into account variation in wetland types and coastal topography. With such a method, large-scale changes could be estimated for specific regions, with a level of accuracy sufficient to guide policymaking at the regional level.

(3) Distinguish among wetland types, including freshwater, transitional, and high and low salt marshes, using the Fish and Wildlife Service habitat classification maps. This would provide a better basis for understanding changing ecological relationships and their implications for future conservation and resource management.

(4) Analyze the change in the boundary between wetland and open sea. Although wetland loss is recognized as deleterious to fisheries and other marine resources, the relationship is not linear. Recent model analysis using a $1 \mathrm{~km}^{2}$ cell grid (Browder, Bartley, and Davis 1985) shows that as the total "interface" of a coastal marsh (area of marsh surface exposed to tidal water) changes as marsh shoreline disintegrates or becomes increasingly indented, nutrient exchange increases to a point and then declines rapidly, affecting the coastal fishery. An analysis of the changing marsh area exposed to tidal waters could be made from the database and SLAMM model used in the present study; such an analysis would help diagnose the changing resource values of the wetlands.

(5) Validate the model, using historic data on changes in coastal wetlands, beaches, and lowlands, accompanying anomalously large subsidence in areas such as the Mississippi Delta in Louisiana, Galveston and Houston, Texas, and San Jose, California.

(6) Use data for remote sensing. This would make it possible to more accurately characterize existing vegetation types. Transect studies could be used to characterize the relationship between vegetation type, frequency of flooding, and elevation, as described by Kana et al. 


\section{CONCLUSION}

Regional pattems of wetland distribution and the potential for loss or gain of wetlands from sea level rise during the next century depend on two principal factors: (1) the tidal range within which wetlands can occur and (2) the extent of the lowest Pleistocene terrace (often found at approximately five feet in elevation above present sea level along tectonically stable coasts).

Thus in New England, where there is virtually no low terrace, marshes occur in association with pocket beaches in small coves and behind small sand spits. Although the tidal range is high and thus favors maintenance of marshes, there is little lowland to be inundated and colonized by marshes. Consequently, after 2075, when sea level rise exceeds the present spring high tide level, present salt marshes will be lost with no compensating gain in new marsh area.

In contrast, from Long Island to southem Florida, coastal slopes are gentle, barrier beaches are common, and the low terrace is widespread. Tidal ranges are also moderately high. Therefore, wetlands are an important component of the coastal system. Furthermore, in many areas, unless development of resort communities precludes inundation of the low terrace, some marshes will expand throughout much of the twenty-first century, decreasing only after the protective beach ridges are breached. However, marshes will be lost in areas that have high coastal dunes or that lack the low terrace.

The Florida Keys and Everglades owe their existence to carbonate deposits that accumulated in shallow water during higher stands of sea level in the Pleistocene. As the Keys are inundated (in the absence of protective measures), a slight increase in mangrove swamps can be anticipated; but after 2075 the region will rapidly become open water. The southern Everglades will also disappear.

The Gulf Coast is also a region of low slopes and barrier coastlines; but, unlike the Atlantic, it has higher terraces along the coast and has very low tidal ranges. Therefore, the marshes are more vulnerable to inundation and cannot migrate inland as readily as the marshes of the Atlantic Coast. With few exceptions, the Gulf Coast marshes will gradually disappear until the barrier islands are breached, at which time the marshes will decline precipitously. A notable exception to this pattem is in the Mississippi Delta, where rapid subsidence is already overwhelming high sedimentation and accretion rates. In general, large-scale loss of marshes (far exceeding the current rate) can be expected in this area early in the next century.

Most of the West Coast is similar to New England: steep, rocky slopes predominate. Wetlands are of minor extent but occupy a wide tidal range, so that they can be expected to persist through most of the next century. The more extensive marshes in the tectonic lowlands of San Francisco Bay and the Washington coast will probably expand onto adjacent lowlands unless restricted by protective structures.

Aggregating the individual case studies provides a convenient way to detect commonalities in wetland response trends throughout the diverse U.S. regions. However, although the study sites were chosen to achieve a representative sample of wetland types without a priori bias as to expected responses, the case study sites were not randomly chosen nor was adequacy of sample size assured. Therefore, the apparent patterns in any area cannot be interpreted as statistically valid estimates of region-wide responses to sea level rise. Instead, the aggregated data are best viewed as indicative of the class of responses likely to occur in coastal areas similar to the case study areas.

The percent change in wetland area at each study site is given in Appendix 4-B. These regional data have been summarized in Table 4-8, shown earlier. The aggregated data illustrate the clear trend toward diminished wetlands in the next century as an overall response to increased sea level rise (Table 4-8). 
Nationally, the 57 sites selected for study include 485,000 ha of coastal wetlands. Under the high scenario, about 73 percent $(192,000$ ha) of the sample wetlands would be lost by 2100 . However, formation of new wetlands reduced the loss to 56 percent of the 1975 wetland area. Under the low scenario, about 40 percent of the 1975 wetlands would be inundated, but new wetlands extended over 85,100 ha, leaving a net reduction by 2100 of 107,000 ha or 22 percent of the 1975 wetlands. The apparent national pattern is dominated by the Gulf Coast, especially the Mississippi Delta, and by the South Atlantic regions where the largest wetland areas are found.

Wetland decline occurred at case study sites from all regions under high scenario conditions except for the relatively small wetland areas considered in the Californian and Columbian provinces. However, in San Francisco Bay, which contains by far the largest area of wetlands, both major losses and gains occurred, depending on local conditions and whether or not wetlands were allowed to migrate. Also, the complex shoreline of Puget Sound probably was not adequately characterized by the selected case studies.

Further east, relatively large wetland losses predominated everywhere under the high scenario. New England and Mississippi Delta study areas lost much, or nearly all, of 1975 wetlands with no compensating gains of new wetlands. Elsewhere along the Atlantic and Gulf Coasts, small-to-low landward gains fell well short of the 1975 wetland losses. Trends under the low scenario were similar for most regions, showing substantial but smaller wetland losses. Clear exceptions occurred, however, in the south Atlantic and in subtropical Florida. In both regions, gains in certain study areas balance significant losses in other areas; thus, values averaged over these regions impart little information.

In summary, some areas may exhibit an increase in wetlands if lowlands are permitted to be inundated by sea level rise; and in some areas existing wetlands may persist well into the next century. Over extensive areas of the United States, however, virtually all wetlands may be lost by 2100 if adjacent lowlands are developed and protected, instead of being reserved for wetland migration.

\section{REFERENCES}

Armentano, T.V., and G.M. Woodwell. 1975. Sedimentation rates in a Long Island marsh determined by $210 \mathrm{~Pb}$ dating. Limnology and Oceanography 20:452-456.

Barth, M.C., and J.G. Titus. 1984. Greenhouse Effect and Sea Leve1 Rise. New York, New York: Van Nostrand-Reinhold Company Inc.

Bartberger, C.E. 1976. Sediment sources and sedimentation rates, Chincoteague Bay, Maryland and Virginia. Joumal of Sedimentary Petrology 46(2):326-336.

Baumann, R.H. 1980. Mechanisms of maintaining marsh elevation in a subsiding environment. M.S. thesis, Louisiana State University, $90 \mathrm{pp}$.

Baumann, R.H., J.W. Day, Jr., and C.A. Miller. 1984. Mississippi deltaic wetland survival: sedimentation versus coastal submergence. Science 224:1093-1094. 334.

Bloom, A.L., and M. Stuvier. 1963. Submergence of the Connecticut coast. Science 139:332

Browder, J.A., H.A. Bartley, and K.S. Davis. 1985. A probabilistic model of the relationship between marshland-water interface and marsh disintegration. Ecological Modelling 29:245-260.

Buttner, P.J.R. 1981. New York's barrier island system. The Conservationist 35(6):26-30.

Costanza, R., C. Neill, S.G. Leibowitz, J.R. Fruci, L.M. Bahr, Jr., and J.W. Day, Jr. 1983. Ecological Models of the Mississippi Deltaic Plain Region: Data Collection and Presentation. U.S. Fish and Wildlife Service, Division of Biological Services, Washington, D.C. FWS/OBS-82/68, 342 pp.

Costanza, R. and F.H. Sklar. 1985. Articulation, accuracy and effectiveness of mathematical models: a review of freshwater wetland applications. Ecological Modelling 27:45-68. 

Verlag.

Davis, R.A. 1985. Coastal Sedimentary Environments. New York, New York: Springer

Day, J.W., Jr., W.G. Smith, P.R. Wagner, and W.C. Stowe. 1973. Community structure and carbon budget of a salt marsh and shallow bay estuarine system in Louisiana. Center for Wetland Resources, Louisiana State University, Baton Rouge. Publ. No. LSU-SG-72-04.

DeLaune, R.D., R.H. Baumann, and J.G. Gosselink. 1983. Relationships among vertical accretion, coastal submergence, and erosion in a Louisiana Gulf Coast Marsh. Joumal of Sedimentary Petrology 53(1):147-157.

Emery, K.0., and E. Uchupi. 1972. Western North Atlantic Ocean Memoir 17. American Association of Petroleum Geologists. Tulsa, Oklahoma.

Flessa, K.W., K.J. Constantine, and M.K. Kushman. 1977. Sedimentation rates in a coastal marsh determined from historical records. Chesapeake Science 18:172-176.

Gosselink, J.G. 1984. The Ecology of Delta Marshes of Coastal Louisiana: A Community Profile. U.S. Fish and Wildlife Service. Washington, D.C. FWS/OBS-84/09.

Gosselink, J.G., and R.H. Baumann. 1980. Wetland Inventories: Wetland loss along the United States coast. Z. Geomorphol. N.F. 34:173-187.

Harrison, E.Z., and A.L. Bloom. 1977. Sedimentation rates on tidal marshes in Connecticut. Joumal of Sedimentary Petrology 47:1484-1492.

Hatton, R.S., R.D. DeLaune, and W.H. Patrick. 1983. Sedimentation, accretion and subsidence in marshes of Barataria Basin, Louisiana. Limnology and Oceanography 28:494-502.

Hicks, S.D. 1978. An average geopolitical sea level series for the United States. Joumal of Geophysical Research 83:1377-1379.

Hicks, S.D., H.A. DeBaugh, and L.E. Hickman. 1983. Sea Level Variation for the United States 1855-1980. Rockville, MD: National Ocean Service.

Holdahl, S.R., and N.L. Morrison. 1974. Regional investigations of vertical crustal movements in the U.S., using precise relevelings and mareograph data. In Recent Crustal Movements and Associated Seismic and Volcanic Activity, R. Green, ed., Tectonophysics 23(4):373-390.

Holmes, A. 1965. Principles of Physical Geology. Second Edition. New York, New York: The Ronald Press Company.

IAPSO Advisory Committee on Tides and Mean Sea Level. 1985. Changes in Relative Mean Sea Level. Eos, Transactions, American Geophysical Union, 66:45:754-756.

Kana, T.W., B.J. Baca, and M.L. Williams. 1986. Potential Impact of Sea Level Rise on Wetlands Around Charleston, South Carolina. Washington, D.C.: U.S. EPA. (Also see Chapter 2 , this report.)

Kana, T.W., W.C. Eiser, B.J. Baca, and M.L. Williams. 1988. "New Jersey Case Study." In Greenhouse Effect, Sea Level Rise, and Coastal Wetlands. Washington, D.C., U.S. Environmental Protection Agency. Chapter 3, this report.

Keene, H.W. 1971. Postglacial submergence and salt marsh evolution in New Hampshire. Maritime Sediments 7:64-68.

Leatherman, S.P. 1983. Barrier island evolution in response to sea level rise: A discussion. Joumal of Sedimentary Petrology 53:1026-1033.

Lord, J.C. 1980. The chemistry and cycling of iron, manganese, and sulfur in salt marsh sediments. Ph.D. thesis, University of Delaware.

Meade, R.H. 1969. Landward transport of bottom sediments in estuaries of the Atlantic coastal plain. Journal of Sedimentary Petrology 39:222-234.

Miller, W.B. and F.E. Egler. 1950. Vegetation of Wequetequock-Pewcatuck tidal-marshes, Connecticut. Ecological Monographs 20:143-172.

Mitsch, W.J., J.W. Day, Jr., J.R. Taylor, and C.H. Madden. 1982. Models of North American freshwater wetlands. International Joumal of Ecology and Environmental Science 8:109-104. 
Muzyka, L.J. 1976. $210 \mathrm{~Pb}$ chronology in a core from the Flax Pond marsh, Long Island. M.S. thesis, SUNY, Stony Brook, 73 p.

Nixon, S.W. 1982. The Ecology of New England High Salt Marshes: A Community Profile. U.S. Fish and Wildlife Service, Office of Biological Services. Washington, D.C. FWS/PBS-81/55.

Odum, E.P., and M.E. Fanning. 1973. Comparison of the productivity of Spartina altermiflora and Spartina cynosuroides in Georgia coastal marshes. Georgia Academy of Science Bulletin 31:1-12.

Odum, W.E., C.C. Mclvor, and T.J. Smith. 1982. The Ecology of the Mangroves of South Florida: A Community Profile. U.S. Fish and Wildlife Services. Washington, D.C. FWS/OBS-81/24.

Oldale, R.N., and C.J. O'Hara. 1980. New radiocarbon dates from the inner continental shelf off southeastern Massachusetts and a local sea-level-rise curve for the past 12,000 years. Geology 8:102-106.

Park, R.A., and D.P. Carlisle. 1976. A Model for Projecting Land Uses and their Impacts on Ecosystems. In Ecosystem Impacts of Urbanization Assessment Methodology, edited by D.L. Jameson, pp. 2.1-2.12. U.S. Environmental Protection Agency. Washington, D.C. EPA-600/ 3-76-072.

Rampino, M.E., and J.E. Sanders. 1980. Holocene transgression in south-central Long Island, New York. Joumal of Sedimentary Petrology 50(4):1063-1080.

Redfield, A.C. 1965. The thermal regime in salt marsh peat at Barnstable, Massachusetts. Tellus 16:246-259.

Redfield, A.C. 1967. Postglacial change in sea level in the western North Atlantic Ocean. Science 157:687-692.

Redfield, A.C. 1972. Development of a New England salt marsh. Ecological Monograph 42:201-237.

Richard, G.A. 1978. Seasonal and environmental variations in sediment accretion in a Long Island salt marsh. Estuaries 1(1):29-35.

Richard, H.G. 1962. Studies on the Marine Pleistocene. Part 1: The Marine Philosophical Society, New Series 52. American Philosophical Society, Philadelphia.

Sanders, J.E., and N. Kumar. 1975. Evidence of shoreface retreat and inplace "drowning" during Holocene submergence of barriers, shelf off Fire Island, New York. Geological Society of America Bulletin 86:65-76.

Seliskar, D.M., and J.L. Gallagher. 1983. The Ecology of Tidal Marshes of the Pacific Northwest Coast: A Community Profile. U.S. Fish and Wildlife Service. Washington, D.C. FWS/OBS-82/32.

Sklar, F.H., R. Costanza, and J.W. Day, Jr. 1985. Dynamic spatial simulation modeling of coastal wetland habitat succession. Ecological Modelling 29:261-281.

Stearns, L.A., and D. McCreary. 1957. The case of vanishing brick dust. Mosquito News 17:303-304.

Teal, J., and M. Teal. 1969. Life and Death of the Salt Marsh. New York, New York: National Audubon Society.

Tiner, R.W., Jr. 1984. Wetlands of the United States: Current Status and Recent Trends. U.S. Fish and Wildlife Service. Washington, D.C.

Wiegert, R.G., R.R. Christian, J.L. Gallagher, J.R. Hall, R.D.H. Jones, and R.L. Wetzel. 1975. A preliminary ecosystem model of a coastal Georgia Spartina marsh. In Estuarine Research, Vol. 1, edited by L.E. Cronin, 583-601. New York, New York: Academic Press. 
COASTAL SITES USED IN MODEL

(See page 138 for explanation of abbreviations and key to column entries)

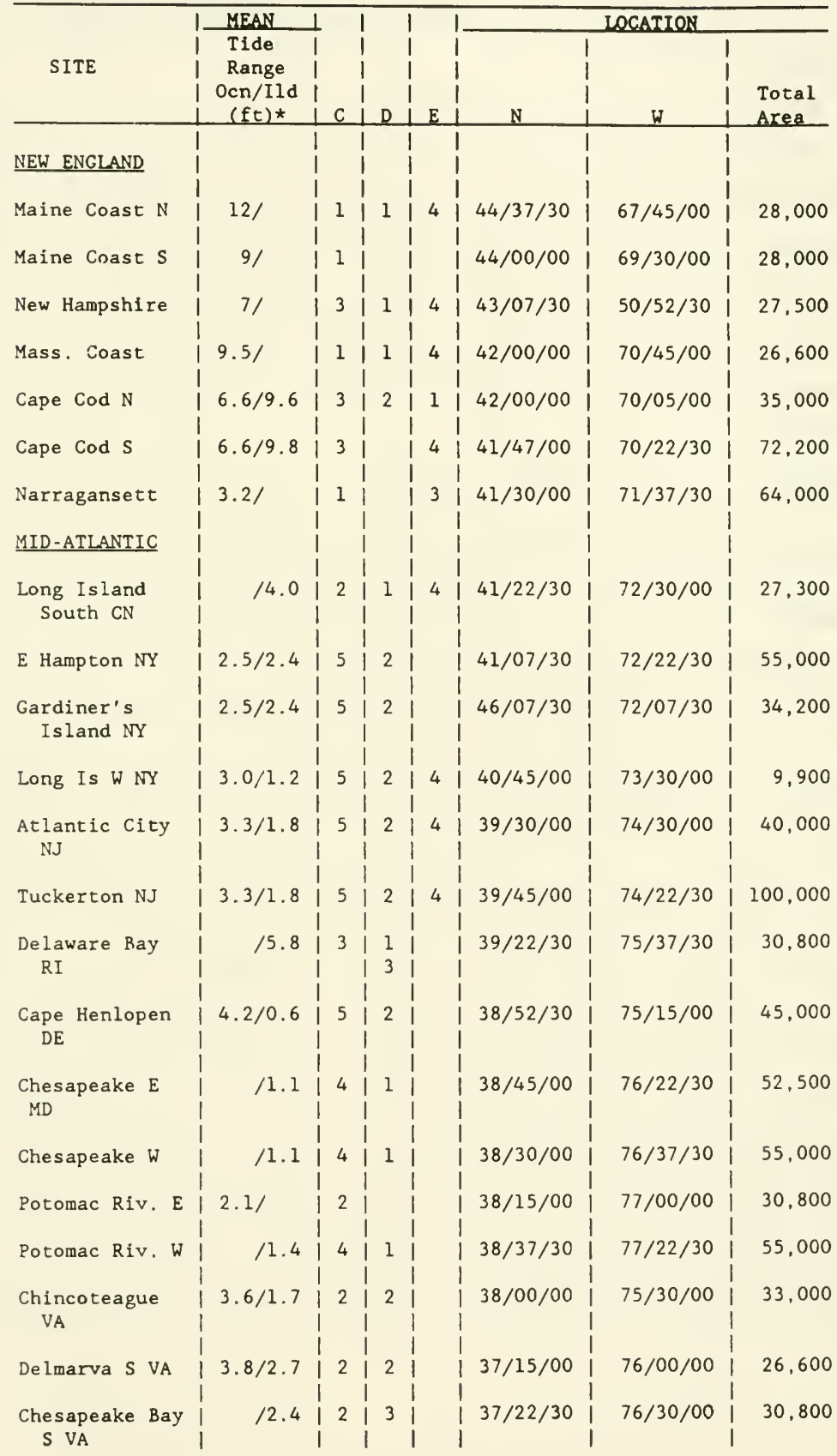




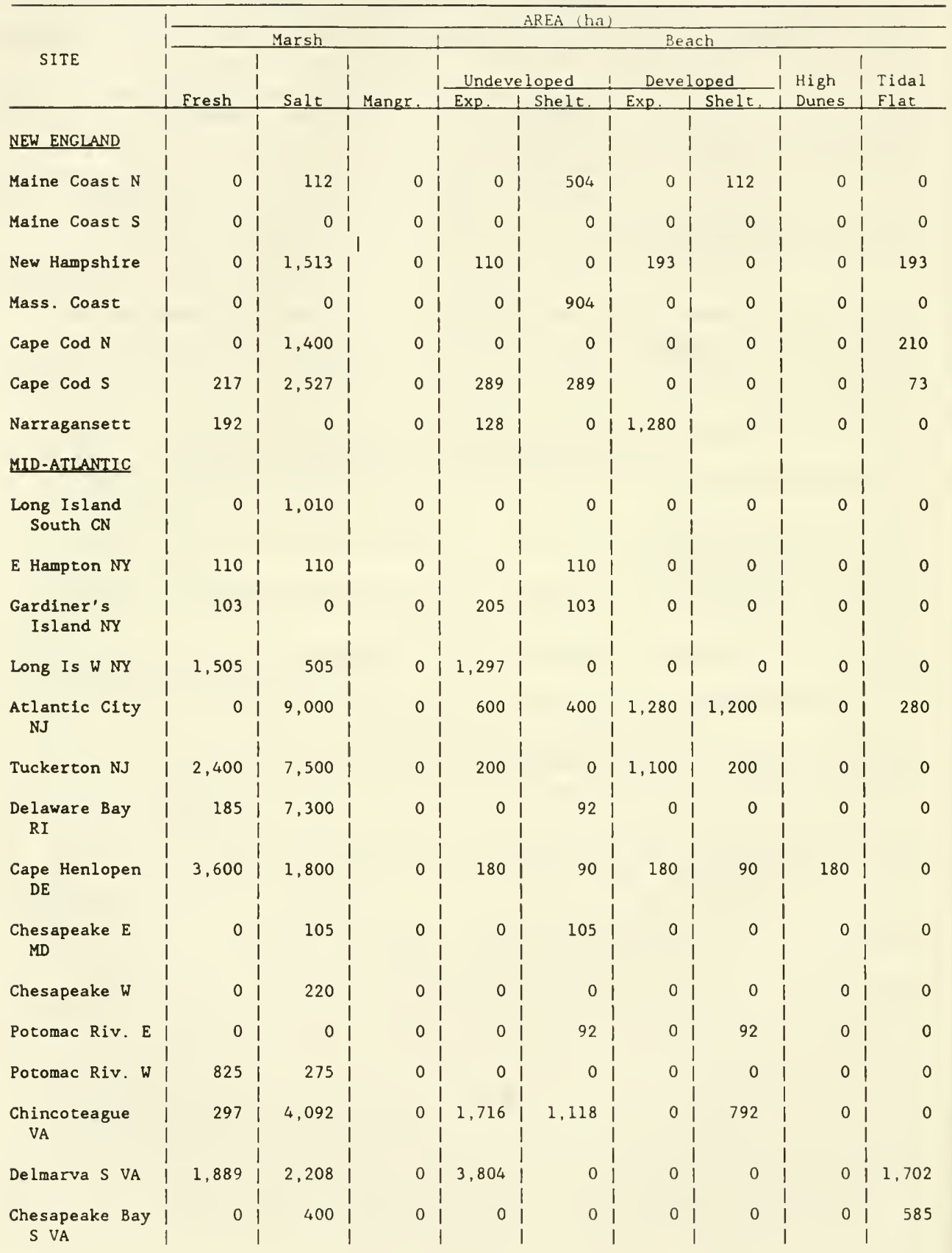




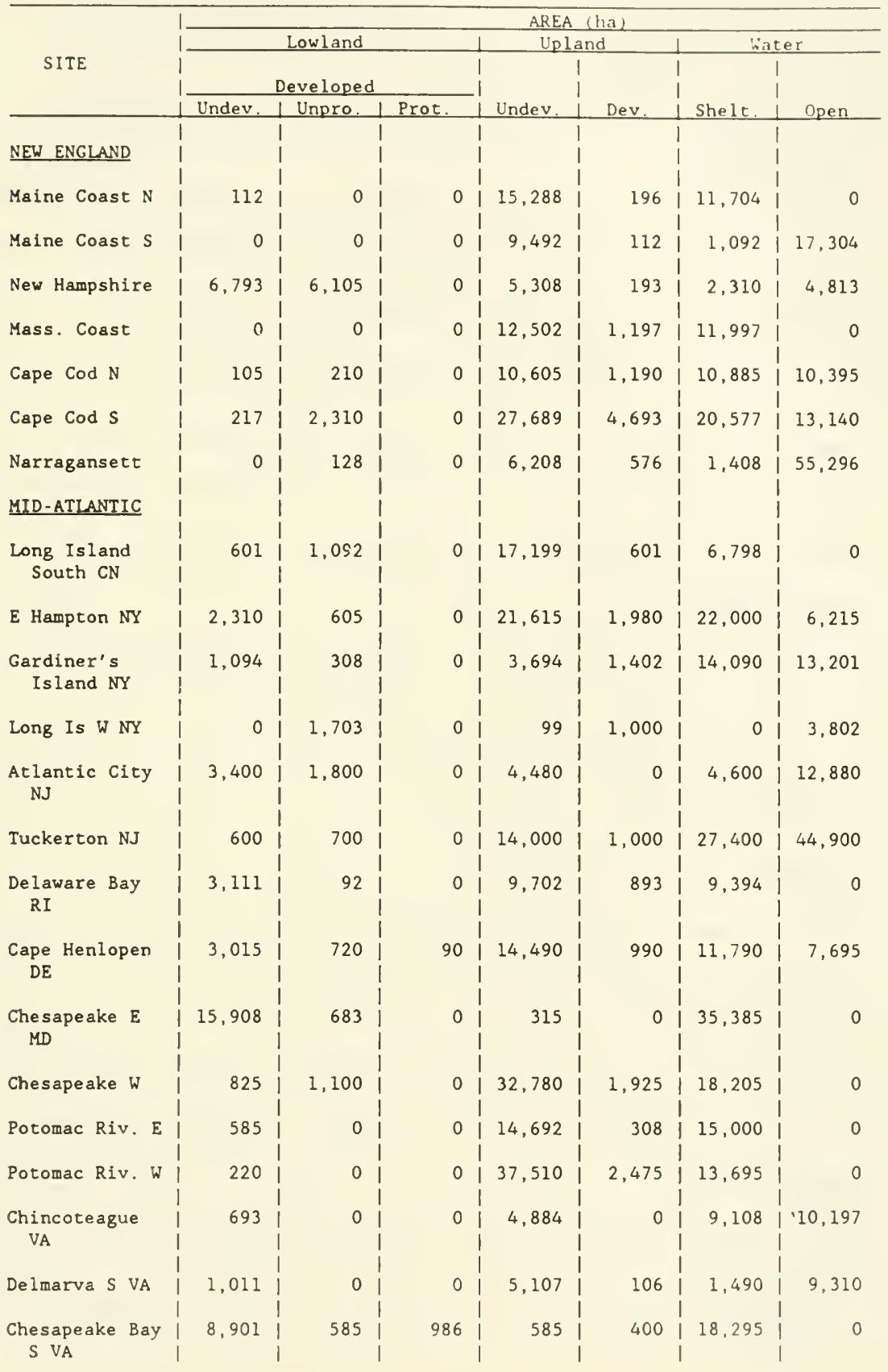




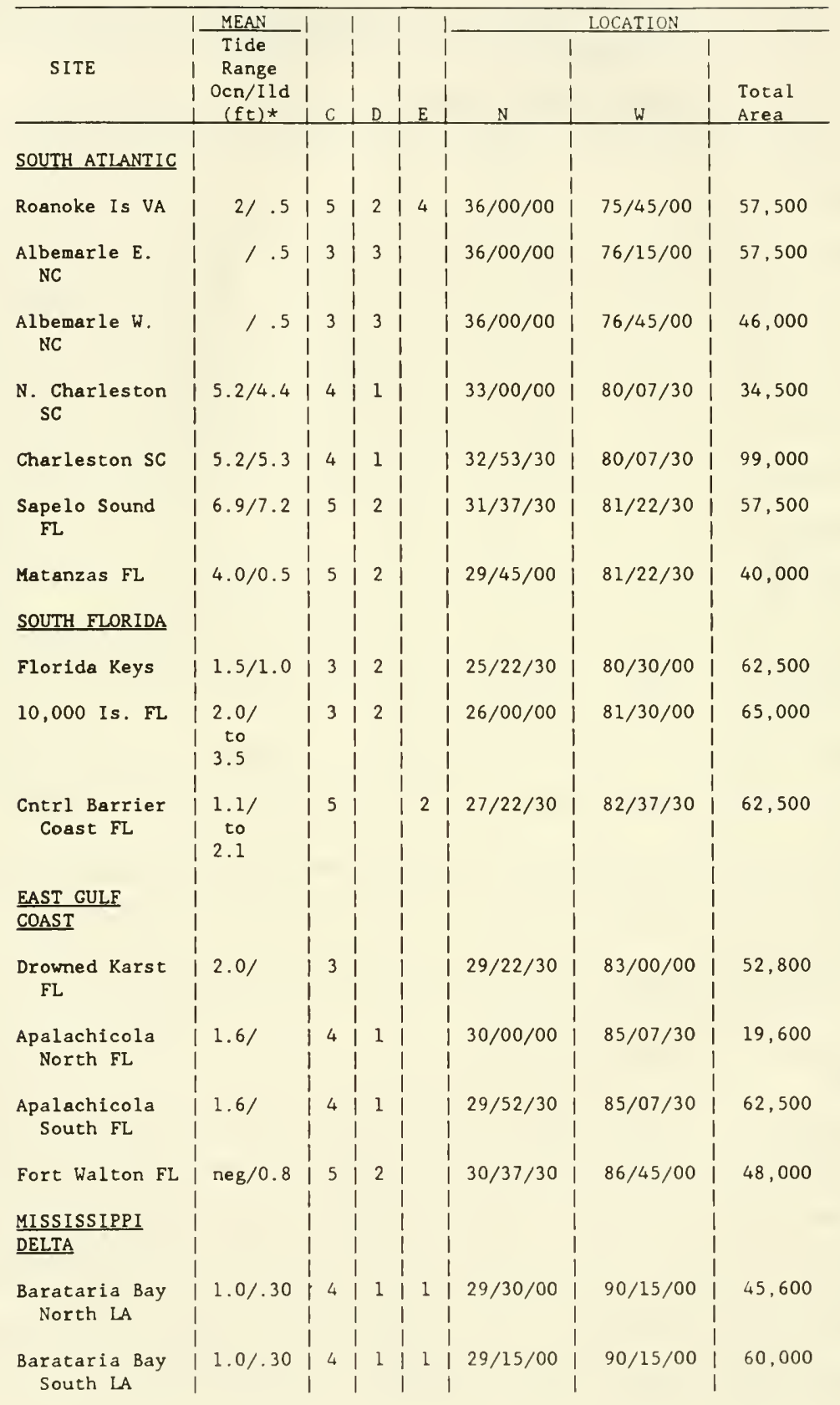




\section{COASTAL SITES USED IN MODEL (Continued)}

\begin{tabular}{|c|c|c|c|c|c|c|c|c|c|}
\hline \multirow{5}{*}{ SITE } & \multicolumn{9}{|c|}{ AREA (ha) } \\
\hline & \multicolumn{3}{|c|}{ Marsh } & \multicolumn{6}{|c|}{ Beach } \\
\hline & \multirow{3}{*}{ Fresh } & \multirow[b]{3}{*}{ Salt } & 1 & \multirow{2}{*}{\multicolumn{2}{|c|}{ Undeveloped }} & \multirow{2}{*}{\multicolumn{2}{|c|}{ Developed }} & \multirow{3}{*}{$\begin{array}{l}\text { High } \\
\text { Dunes }\end{array}$} & \\
\hline & & & i & & & & & & Tidal \\
\hline & & & 1 Mangr. & Exp. & 1 Shelt. & Exp. & 1 Shelt. & & 1 Flat \\
\hline & I & 1 & 1 & 1 & 1 & I & 1 & 1 & 1 \\
\hline SOUTH ATLANTIC & i & j & i & i & i & i & I & i & i \\
\hline & i & i & i & i & i & i & i & i & i \\
\hline Roanoke Is VA & 1,495 & 3,278 & 0 & 115 & 215 & 0 & i & 2,013 & 0 \\
\hline & i & i & $\mathrm{i}$ & i & i & i & $i$ & i & i \\
\hline Albemarle $\mathbf{E}$. & I 20,298 & 4,773 & 0 & 173 & 0 & 0 & i & 0 & 0 \\
\hline NC & I & i & i & i & i & i & i & i & i \\
\hline & i & $i$ & i & i & i & i & i & i & i \\
\hline Albemarle $W$. & 3,910 & 1,196 & 0 & 0 & 0 & 0 & $i$ & 0 & 0 \\
\hline NC & i & i & i & i & i & i & i & i & i \\
\hline & 1 & $\mathrm{i}$ & 1 & i & I & 1 & 1 & | & | \\
\hline N. Charleston & 3,312 & 4,899 & 0 & 0 & 104 & 0 & i & 0 & 0 \\
\hline SC & i & $\mathrm{i}$ & i & i & i & i & i & 1 & i \\
\hline & $\mathrm{i}$ & i & $\mathrm{i}$ & i & i & i & $i$ & i & i \\
\hline Charleston SC & 4,500 & i 18,700 & 0 & 700 & 0 & 400 & 100 & 0 & 400 \\
\hline & 1 & i & i & i & i & i & i & i & i \\
\hline Sapelo Sound & 115 & i 21,103 & 0 & 518 & 288 & 0 & i & 0 & 2,013 \\
\hline FL & i & i & i & i & i & i & i & i & i \\
\hline & I & i & i & i & i & 1 & I & i & i \\
\hline Matanzas FL & 2,800 & 80 & 800 & 200 & 0 & 0 & i & 200 & 0 \\
\hline & i & i & i & i & i & i & i & i & i \\
\hline SOUTH FLORIDA & i & $i$ & i & i & i & i & $i$ & i & 1 \\
\hline & i & $\mathrm{i}$ & i & i & i & i & i & i & i \\
\hline Florida Keys & 16,813 & i & 6,438 & 0 & 0 & 0 & i & 0 & 0 \\
\hline & 1 & 1 & 1 & 1 & 1 & I & I & i & i \\
\hline 10,000 Is. FL & i 12,415 & 5,200 & 18,785 & 0 & 0 & 0 & i & 0 & 0 \\
\hline & i & i & i & i & i & i & i & $\mathrm{i}$ & i \\
\hline & i & i & I & I & 1 & I & I & i & i \\
\hline Cntrl Barrier & 0 & i & 125 & 500 & 0 & 1,000 & 313 & 0 & 0 \\
\hline Coast FL & I & i & i & i & i & i & i & i & i \\
\hline & I & i & i & i & i & i & i & i & i \\
\hline EAST GULF & i & i & i & i & i & i & i & i & i \\
\hline COAST & i & i & i & i & i & i & i & i & i \\
\hline & 1 & i & i & i & i & i & i & i & i \\
\hline Drowned Karst & i 26,506 & 2,218 & 0 & 0 & 0 & 0 & I & 0 & 0 \\
\hline FL & i & 1 & i & i & i & i & 1 & i & i \\
\hline & & i & i & i & i & i & i & i & i \\
\hline Apalachicola & | 16,992 & 0 & 0 & 0 & 0 & 0 & I & 0 & 0 \\
\hline North FL & i & i & i & i & i & i & 1 & i & i \\
\hline & i & $\mathrm{i}$ & i & i & i & i & $i$ & i & i \\
\hline Apalachicola & 23,813 & 3,688 & 0 & 0 & 0 & 0 & 1 & 0 & 0 \\
\hline South FL & i & i & i & i & i & i & i & i & i \\
\hline & & i & i & i & i & i & i & i & i \\
\hline Fort Walton FL & 288 & 96 & 0 & | 1,392 & 96 & 192 & i & 0 & i \\
\hline & I & I & i & i & i & 1 & i & $\mathrm{i}$ & i \\
\hline MISSISSIPPI & i & i & $\mathrm{i}$ & i & i & i & i & i & i \\
\hline DELTA & i & i & i & i & i & i & i & i & i \\
\hline & & i & i & i & i & i & i & $\mathrm{i}$ & i \\
\hline Barataria Bay & 10,716 & 8,482 & 0 & 0 & 0 & 0 & i & 0 & i \\
\hline North LA & i & i & i & i & i & i & $i$ & i & i \\
\hline & & i & i & i & i & & $i$ & $\mathrm{i}$ & i \\
\hline Barataria Bay & 28,680 & 11,280 & 0 & 0 & i & i & $i$ & i & i \\
\hline South LA & I & 1 & 1 & I & I & i & 1 & i & i \\
\hline
\end{tabular}


COASTAL SITES USED IN MODEL (Continued)

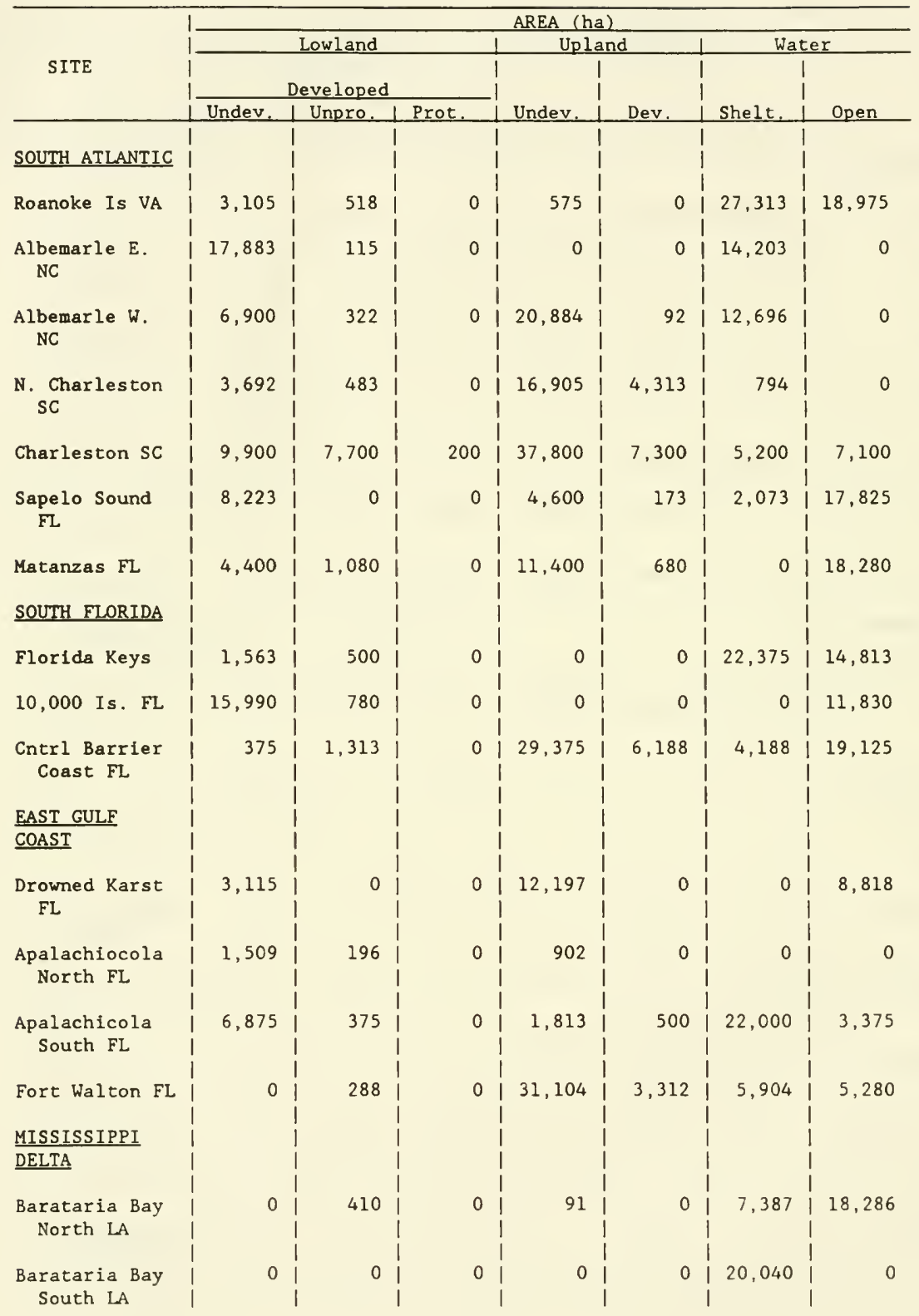









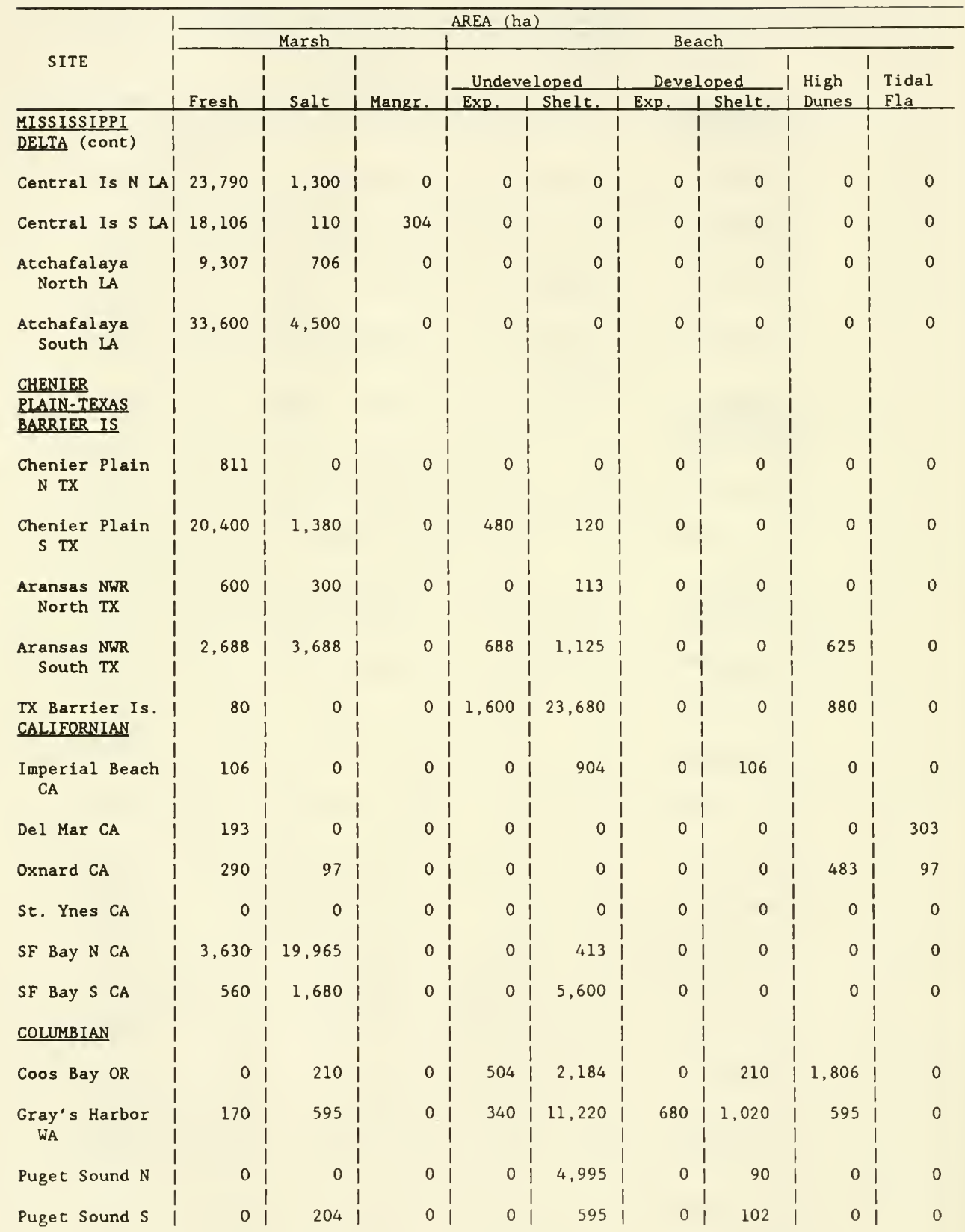


COASTAL SITES USED IN MODEL (Continued)

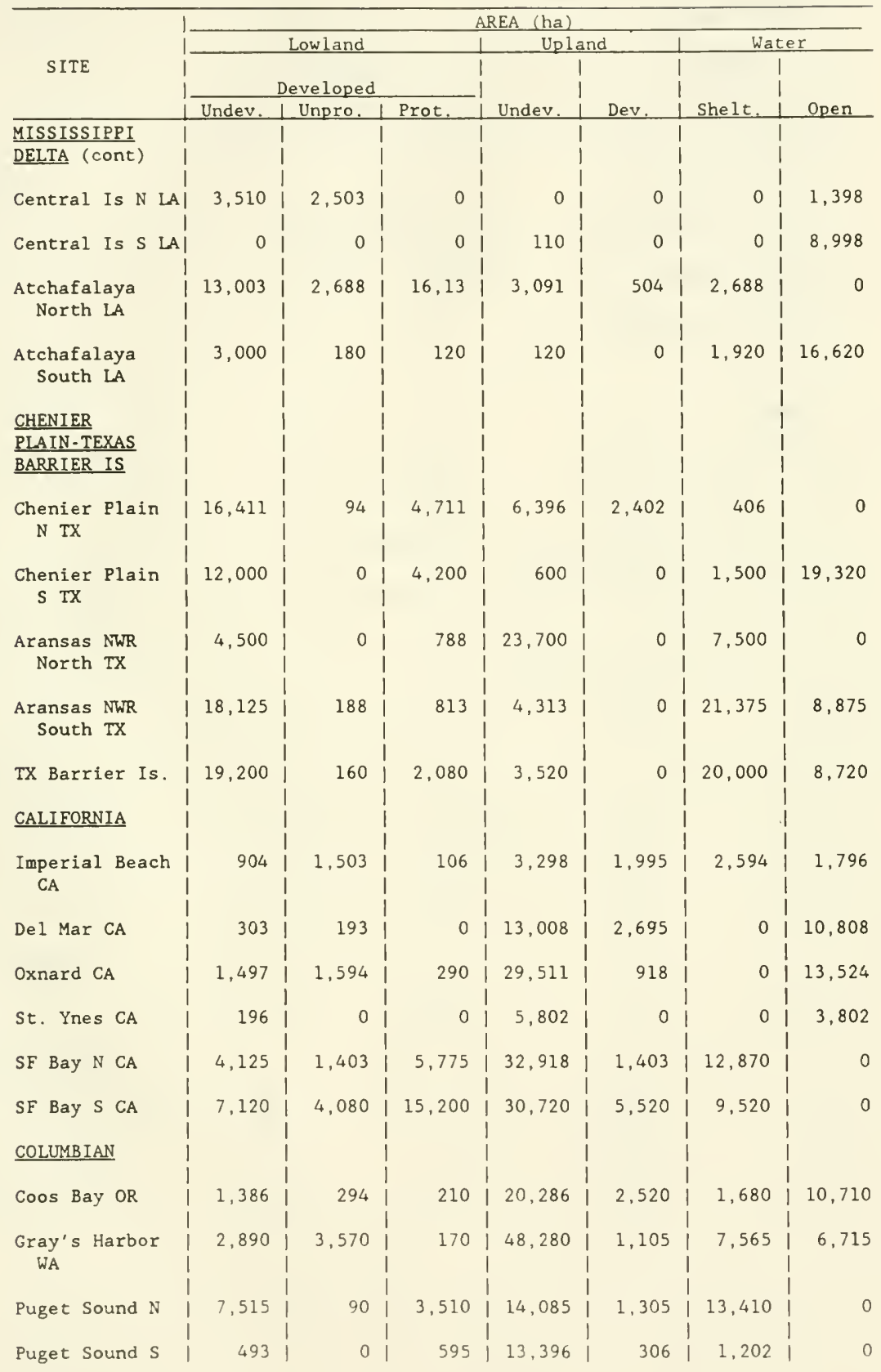




\section{LEGEND FOR APPENDIX 4-A}

\section{ABBREVIATIONS:}

$\mathrm{N}$ - North

S - South

Mangr - Mangrove

Dev - Developed

Undev - Undeveloped

Exp - Exposed

Shelt - Sheltered

\section{KEY:}

C - Coastal Line Type

1. Steep

2. Low Slope, Terraced

3. Low Slope, Unterraced

4. Deltaic

5. Barrier Islands/Dunes

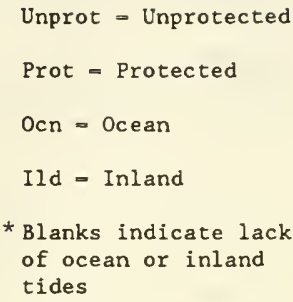

D = Wetland Types

1. Deltaic

2. Lagoonal

3. Estuarine

4. Mosquito Ditches
$E=$ Engineering Structures

1. Levee

2. Seawall

3. Breakwater 


\begin{tabular}{|c|c|c|c|c|}
\hline \multirow[b]{2}{*}{ Location } & \multicolumn{2}{|c|}{ LOW } & \multicolumn{2}{|c|}{ HIGH } \\
\hline & Lost & Gained & Lost & Gained \\
\hline \multicolumn{5}{|l|}{ NEW ENGLAND } \\
\hline Maine Coast $\mathrm{N}$ & 0 & 0 & 1 & 0 \\
\hline Maine Coast S & 0 & 0 & 0 & 0 \\
\hline New Hampshire Coast & 2 & 0 & 14 & 0 \\
\hline Mass. Coast & 0 & 0 & 0 & 0 \\
\hline Cape Cod N & 0 & 0 & 12 & 0 \\
\hline Cape Cod S & 0 & 0 & 9 & 0 \\
\hline \multirow{2}{*}{\multicolumn{5}{|c|}{ MIO-ATLANTIC }} \\
\hline & & & & \\
\hline Long Istand Sound $\mathrm{CN}$ & 0 & 4 & 6 & 6 \\
\hline E. Hampton NY & 1 & 5 & -2 & 5 \\
\hline Gardiner's Is land NY & 0 & 4 & 1 & 1 \\
\hline Long Is land W NY & 0 & 11 & 19 & 0 \\
\hline Atlantic City NJ & 8 & 31 & 90 & 0 \\
\hline Tuckerton NJ & 74 & 0 & 96 & 0 \\
\hline Delaware Bay DE & 0 & 29 & 60 & 49 \\
\hline Cape Henlopen DE & 18 & 0 & 50 & 0 \\
\hline Chesapeake E MO & 1 & 0 & 1 & 0 \\
\hline Chesapeake W MD & 2 & 3 & 2 & 0 \\
\hline Potomac River E VA & 0 & 1 & 1 & 0 \\
\hline Potomac River W MD & 6 & 0 & 6 & 0 \\
\hline Chincoteague VA & 41 & 1 & 42 & 3 \\
\hline Delmarva VA & 25 & 0 & $\overline{4} 1$ & 1 \\
\hline Chesapeake Bay S VA & 1 & 0 & 1 & 0 \\
\hline \multicolumn{5}{|l|}{ SOUTH ATLANTIC } \\
\hline Roanoke Istand NC & 48 & 0 & 48 & 2 \\
\hline Albemarle WNC & 41 & 0 & 48 & 5 \\
\hline N Charleston SC & 0 & 21 & 52 & 36 \\
\hline Charleston SC & 116 & 65 & 172 & 87 \\
\hline Sapelo Sound GA & 1 & 24 & 165 & 55 \\
\hline Matanzas FL & 8 & 14 & 8 & 37 \\
\hline \multicolumn{5}{|l|}{ SOUTHERN FLORIDA } \\
\hline Florida Keys & 1 & 15 & 236 & 1 \\
\hline 10,000 Is. FL & 0 & 159 & 4 & 159 \\
\hline Cntrl. Barrier Coast FL & 1 & 0 & 1 & 0 \\
\hline \multicolumn{5}{|l|}{ MISSISSIPPI DELTA } \\
\hline Barataria Bay N LA & 192 & 0 & 192 & 0 \\
\hline Barataria Bay S LA & 400 & 0 & 400 & 0 \\
\hline Central Is. N LA & 154 & 0 & 210 & 0 \\
\hline Central Is. S LA & 185 & 0 & 185 & 0 \\
\hline Atchafalaya N LA & 91 & 0 & 92 & 0 \\
\hline Atchatalaya S LA & 381 & 0 & 381 & 0 \\
\hline
\end{tabular}


CHANGE IN WETLAND AREA (Continued)

\begin{tabular}{|c|c|c|c|c|}
\hline \multirow[b]{2}{*}{ Location } & \multicolumn{2}{|c|}{ LOW } & \multicolumn{2}{|c|}{$\mathrm{HIGH}$} \\
\hline & Lost & Gained & Lost & Gained \\
\hline \multicolumn{5}{|c|}{ CHENIER PLAIN-TEXAS BARRIER ISLAND } \\
\hline Chenier Plain N TX & 3 & 14 & 5 & 32 \\
\hline Chenier Plain S TX & 34 & 52 & 132 & 18 \\
\hline Aransas NWR N TX & 8 & 2 & 5 & 15 \\
\hline Aransas NWR S TX & 63 & 0 & 63 & 0 \\
\hline TX Barrier Is. & 1 & 0 & 1 & 0 \\
\hline \multicolumn{5}{|l|}{ CALIFORNIA } \\
\hline Imperial Beach CA & 0 & 0 & 0 & 0 \\
\hline Del Mar CA & 0 & 0 & 2 & 0 \\
\hline Oxnard CA & 1 & 0 & 2 & 0 \\
\hline St. Ynez CA & 0 & 0 & 0 & 0 \\
\hline SF Bay N CA & 89 & 25 & 85 & 31 \\
\hline SF Bay S CA & 1 & 64 & G & 71 \\
\hline \multicolumn{5}{|l|}{ COLUMBIA } \\
\hline $\operatorname{CoOS~Bay~OR~}$ & 0 & 5 & 2 & 3 \\
\hline Gray's Harbor WA & 1 & 23 & 1 & 25 \\
\hline Puget Sound N WA & 0 & 82 & 0 & 90 \\
\hline Puget Sound $S$ WA & 0 & 6 & 0 & 6 \\
\hline
\end{tabular}




\title{
APPENDIX 4-C
}

\section{HOW TO USE THE SLAMM COMPUTER PROGRAM}

The IBM PCexecutable code is SLAMM.COM, so the model is called by entering "SLAMM" in response to the system prompt. The model responds with SIMULATION OPTIONS, which provides defaults for the few parameters required by the model (Figure 4-C-1). In order to change a parameter, the user types the first letter of the desired choice, and then picks the appropriate first letter from among the choices provided. Because we want to use the defaults, we type " $C$ " to continue; " $Q$ " is used to quit the model. The next screen provides OUTPUT OPTIONS with defaults (Figure 4-C-2). We type "T" to change the time step for plotting maps; then we enter " 50 " in order to increase the interval from 25 years (the default) to 50 years. (The model actually plots those years divisible by the specified number without a remainder; so to plot only the year 2050 in addition to the initial and final years, which are always plotted, the user types "2050.") We also type "P" to plot the input data on the screen so that it can be edited.

\section{FIGURE 4-C-1}

\section{OPTIONS AVAILABLE FOR SLAMM SIMULATIONS}

\section{SIMULATION OPTIONS}

Initial year $=1975$

Last year $=2100$

Rate of sea level rise $=$ High $(2.166 \mathrm{~m}$ by 2100$)$

Subsiderice rate for region $=1.20 \mathrm{~mm} / \mathrm{yr}$

Decrease sediment with engineering projects on rivers $=$ TRUE

Protect developed areas $=$ TRUE

Waves from the east

Continue

Quit

FIGURE 4-C-2

OPTIONS AVAILABLE FOR SLAMM OUTPUT

\author{
OUTPUT OPTIONS
}

Dump input data to printer $=$ FALSE

Plot input data on screen $=$ FALSE

Legend = FALSE

Automatically print maps $=$ TRUE

Time step for plotting map $=25.0$

Summarize output = TRUE

Continue 
The model will then request the name of the input data file. Files having the default extension ".DAT" are those that have been prepared and saved by SLAMM; other extensions, such as ".PRT" for files prepared by Lotus 123, must be given by the user. We enter "NJTUCKER" to use the file that has already been edited for Tuckerton, New Jersey, on the default disk drive.

The legend is then plotted on the screen (Figure 4-C-3). It will remain until a key is pressed. If a hard copy is desired, the IBM PrtSc key should be used; remember that GRAPHICS or another screen dump program must have been invoked before calling SLAMM if graphics are to be sent to the printer. The data in the specified file are then plotted on the screen (Figure 4-C-4). The coordinates are used in editing the data and should be noted by the user. The screen is exited by pressing any key, such as the space bar. If the user chooses to edit the data, the $\mathrm{X}$ and $\mathrm{Y}$ coordinates must be entered (Figure 4-C-5).

\section{Undev. Upland}

Undev. Lowl and

Prot. Lowl and

Exp. Beach

Dev. Exp. Beach

Fresh Marsh

Mangrove

She $1 t$. Water

Dike or levee
Dev. Upl and

1

Dev. Lowl and

if High Dunes

', Shelt. Beach

is Dev.Shelt.B.

Salt Marsh

Tidal Flat

Open Sea

Bl ank $r n$

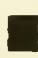

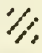

被

.i.

三

五 


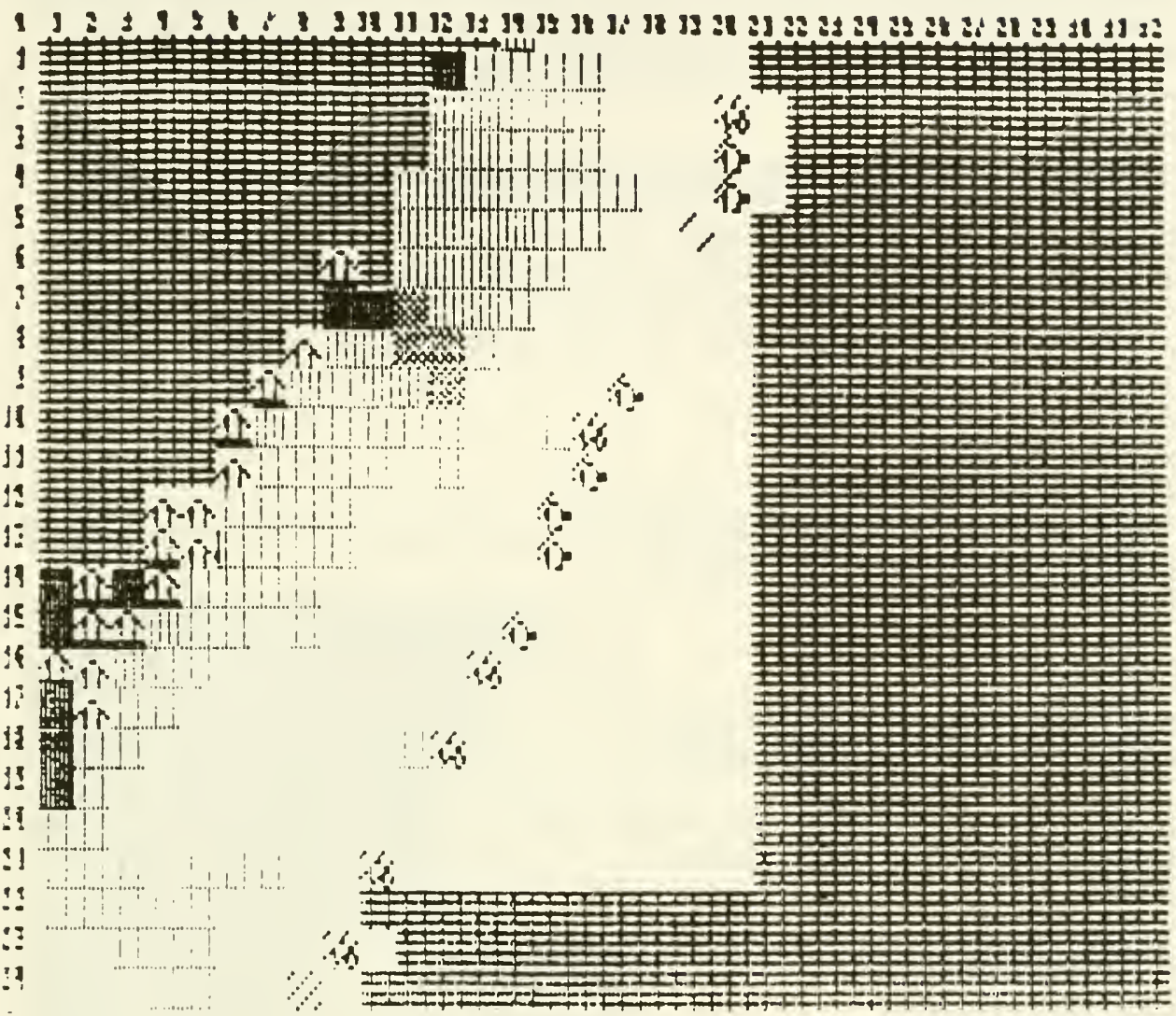

Undev. Upland
Undev. Lowland Deu. Upland
Prot. Lowland " Dev. Lowland
Exp. Beach

$\begin{array}{ll}\text { Deu. Exp.Beach } & \text { to Deu.Shelt.B. } \\ \text { Fresh Marsh } & \text { it Salt Marsh } \\ \text { Mangrove } & + \text { Iidal Flat } \\ \text { Shelt. Water } & \text { Open Sea } \\ \text { Dike or levee } & \text { Blank }\end{array}$

Dike or levee | Blank is

FIGURE 4-C-5

INITIAL DISPLAY FOR EDITING CELLS IN SLAMM SIMULATIONS

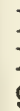

$\mathrm{X}$ coordinate:

9

Y coordinate:

23 
In editing the data, the characteristics of the indicated cell are displayed along with EDIT OPTIONS (Figure 4-C-6). The user then chooses the desired option, such as "D" to change the dominant category. We then choose "9" to change the cell from Developed Sheltered Beach to Developed Exposed Beach (Figure 4-C-7). Other changes may be made until the user types " $\mathrm{C}$ " to continue (Figure 4-C-8), at which time the map is again displayed.

\section{FIGURE 4-C-6}

\section{OPTIONS FOR EDITING RAW DATA BEFORE SIMULATING SEA LEVEL RISE}

9.23. Dev.Shelt.B. Elev. = 1.00

Protected by dike or levee $=$ FALSE Developed $=$ TRUE

\section{EDIT OPTIONS}

Dominant cell category

Average elevation

Protected by dike or levee

Residential or commercial development

Edit another cell (without plotting)

Continue

\section{FIGURE 4-C-7}

\section{CELL CATEgories AVAILABLE FOR}

EDITING RAW DATA USED IN SLAMM

Residential or commercial development

Edit another cell (without plotting)

Continue

\section{Cell categories}

1 Undev. Upland

2 Dev. Upland

3 Undev. Lowland

4 Dev. Lowland

5 Prot. Lowland

6 High Dunes

7 Exp. Beach

8 Shelt. Beach

9 Dev. Exp. Beach

10 Dev. Shelt. B

11 Fresh Marsh

12 Salt Marsh

13 Mangrove

14 Tidal Flat

15 Shelt. Water

16 Open Sea

Choose number:

9
FIGURE 4-C-8

DISPLAY AFTER EDITING DOMINANT CELL CATEGORY AND EDIT OPTIONS

9.23. Dev.Shelt.B. Elev. $=1.00$

Protected by dike or levee $=$ FALSE

Developed $=$ TRUE

\section{EDIT OPTIONS}

Dominant cell category

Average elevation

Protected by dike or levee

Residential or commercial development Edit another cell (without plotting)

Continue 
When finished with editing and displaying the updated map, the user is given the opportunity to save the data under the same file name or under a new name. We will press the return key because we do not wish to save the change permanently. The model seems to pause for a few seconds while it converts the blank cells to water, lowland, or upland, depending on the categories of the adjacent cells. A summary of the initial conditions is then printed. Note: it is assumed that a printer using Epson/BM printer protocol is connected and ready to receive output.

The next display is a map of the categories at the initial time step (Figure 4-C-9). However, it may differ from the input data if there were conflicts between the categories and the other characteristics for any of the cells. To ensure that the initial conditions are consistent for the site, SLAMM applies all the transfer algorithms at the beginning of the simulation before incrementing sea level. For example, the beach cell south of cell A was converted from sheltered beach to exposed beach because it is adjacent to open sea. The conditions and distribution of

FIGURE 4-C.9

SIMULATION MAP OF TUCKERTON, N.J., AT INITIAL TIME STEP

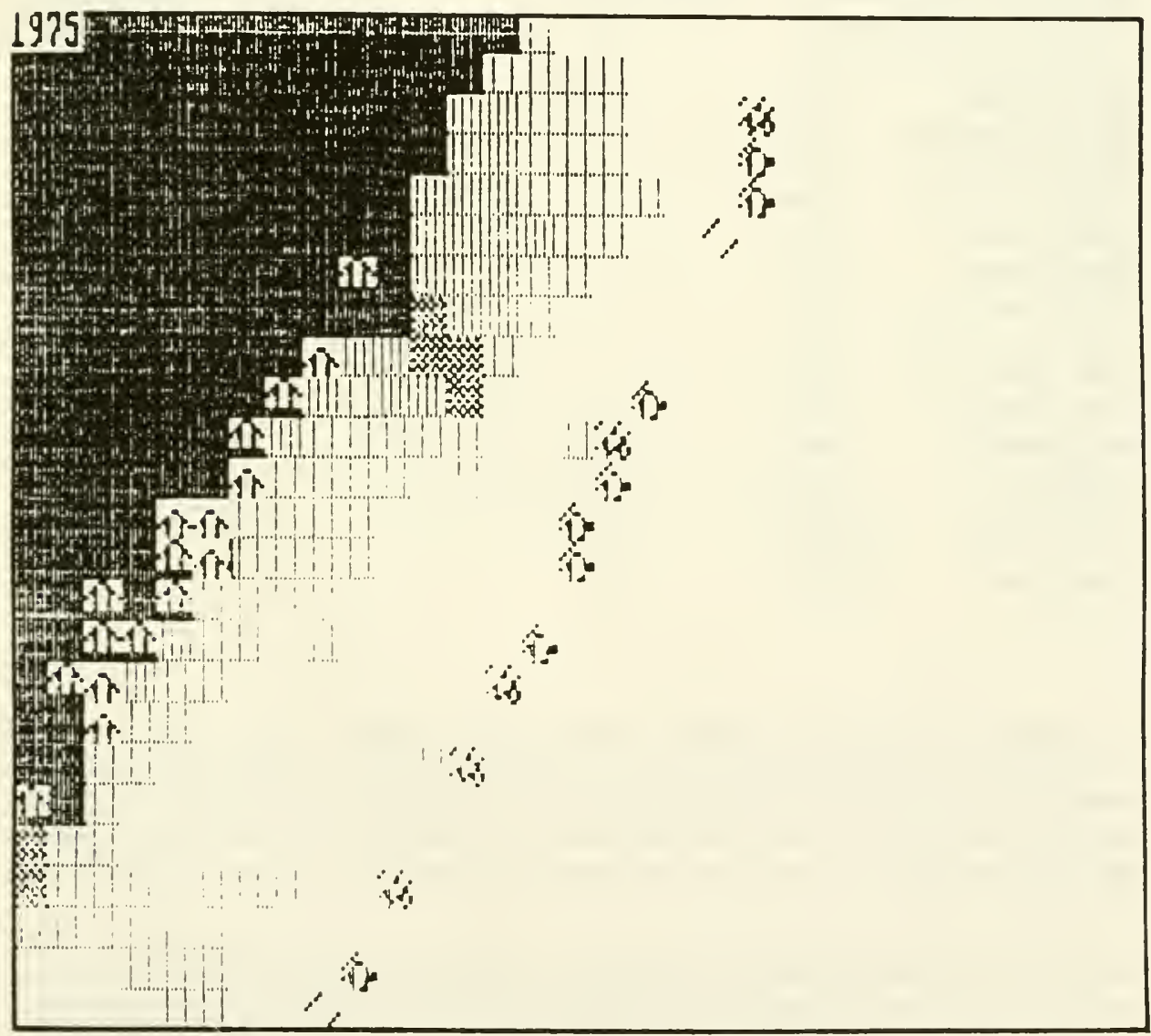


the categories are again summarized (Figure 4-C-10). The conditions include the present sea level with respect to the initial datum, the instantaneous rate of sea level rise, the subsidence rate (which is constant for a simulation), and the marsh accretion and subtidal sedimentation rates (which may vary as the percentage of wetlands varies).

\section{FIGURE 4-C-10 \\ INITIAL CONDITIONS AND ABUNDANCE OF EACH LAND CATEGORY AT TUCKERTON, N.J.}

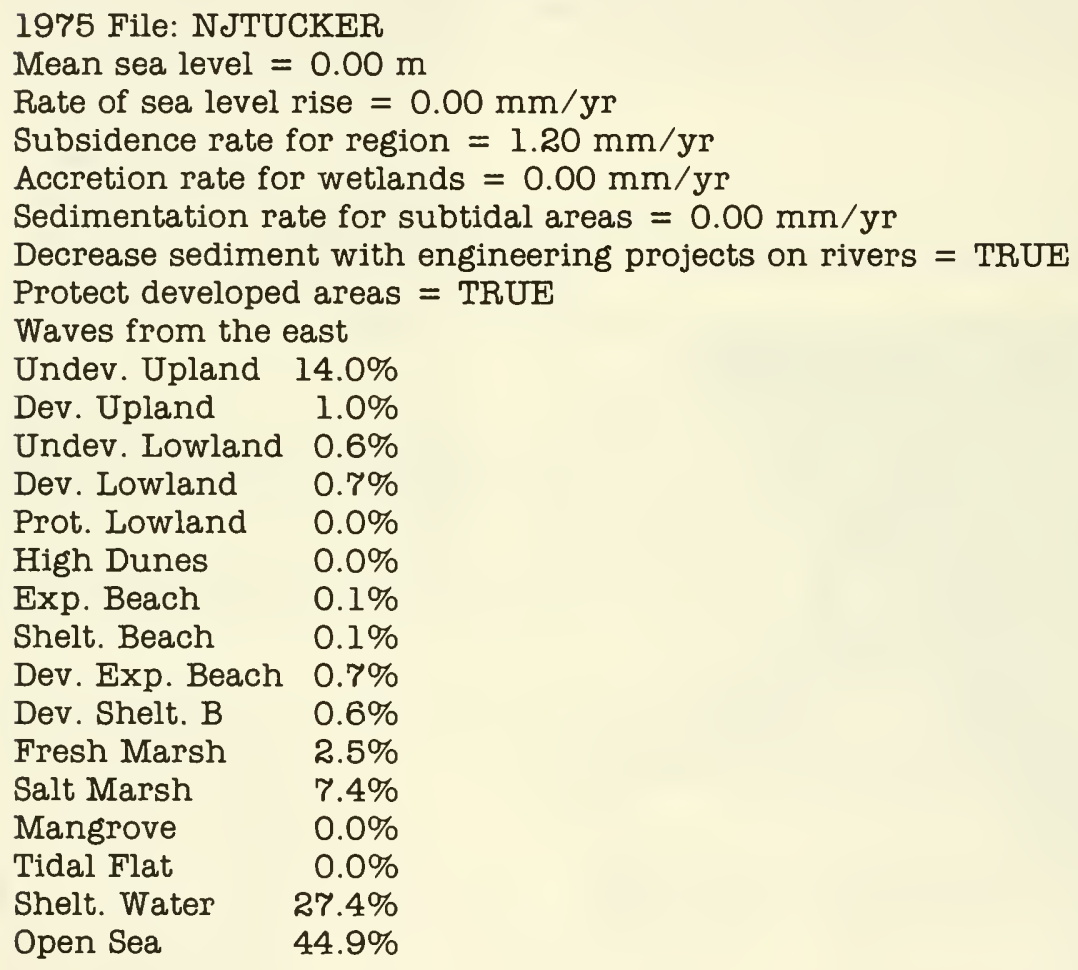

Regardless of the interval chosen for plotting the map output, summary output is provided on the printer at a 25-year interval. The next screen display is of the updated map following the chosen interval, in this case 50 years (Figure $4-\mathrm{C}-11$ ). Note that all the freshwater marsh has been converted to salt marsh but that no wetland has yet been lost. The cell just west of cell $\mathrm{B}$ has been converted from upland to lowland, and several of the lowland cells have been converted to tidal flat.

Again, summary output is sent to the printer, and the next updated map is plotted, in this case for the year 2100 (Figure 4-C-12). Regardless of plotting interval, the final map is plotted so that the user can see the terminal conditions in graphic form. Unlike the intermediate maps, which remain only as long as required to print and to compute new conditions, the final map remains on the screen until a key is pressed. 
TUCKERTON, N.J., IN THE YEAR 2050 WITH HIGH SEA LEVEL RISE.

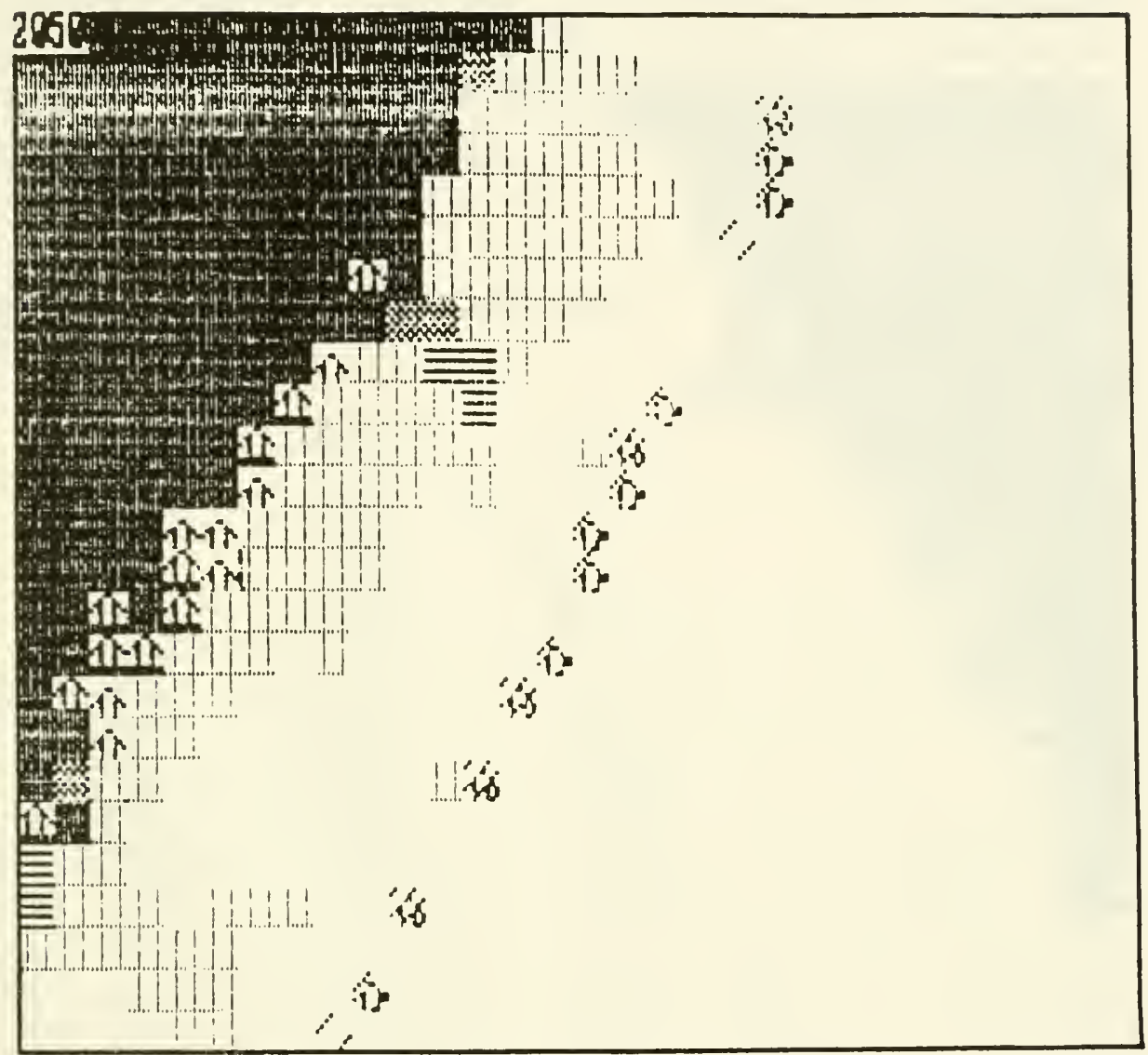


FIGURE 4-C-12

TUCKERTON, N.J., AT END OF SIMULATION (YEAR 2100) WITH HIGH SEA

LEVEL RISE, PROTECTION OF DEVELOPED AREAS, AND SUBSIDENCE EQUAL TO

$1.2 \mathrm{MM} / \mathrm{YR}$.

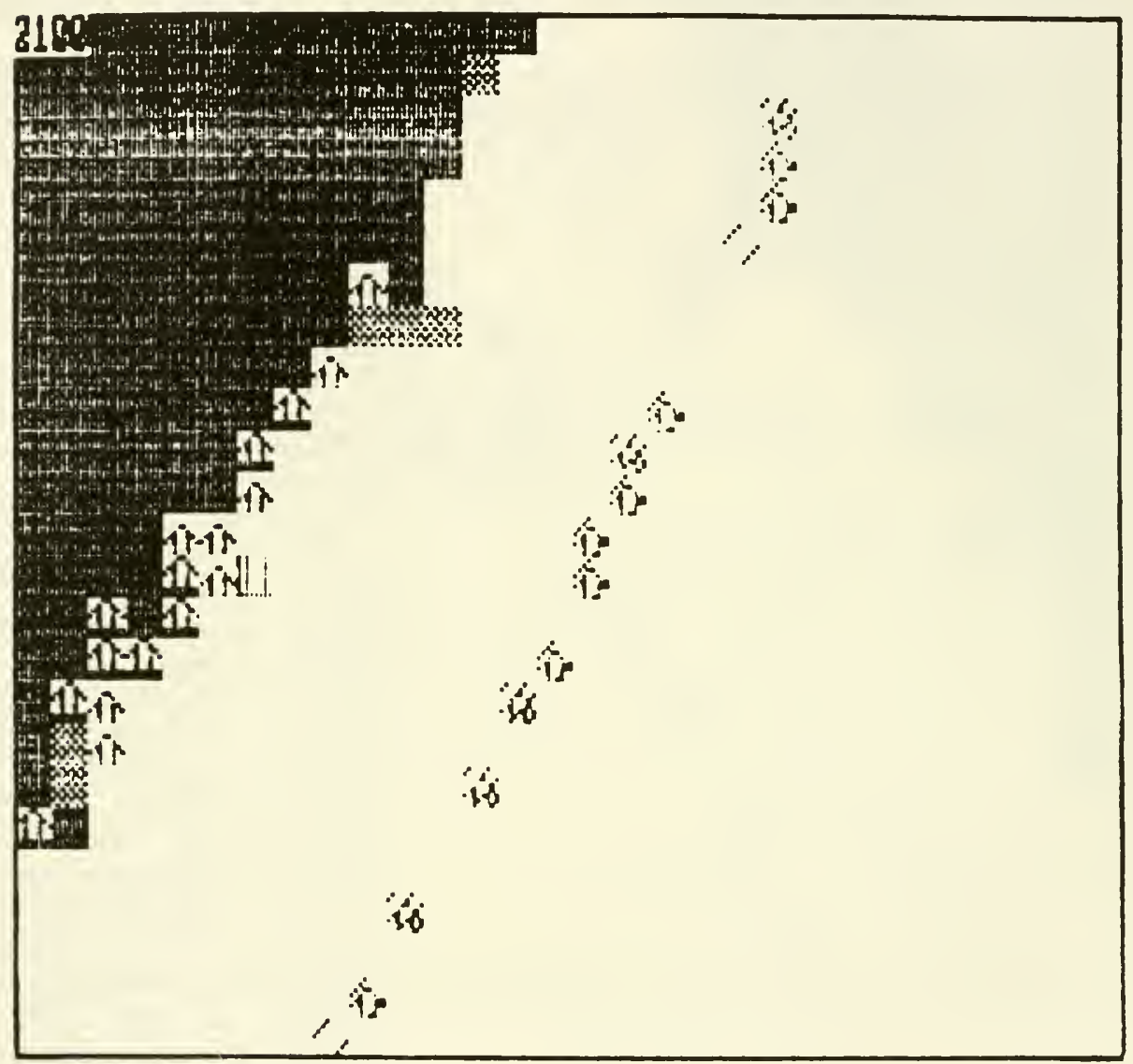


Finally, a summary table of percent changes in wetland areas at 5-year intervals is printed (Table 4-C-1). Types of wetlands are not differentiated in the summary because the model should not be used to interpret detailed changes between freshwater and saltwater types (see Assumptions). In this example only $1 \%$ of the original wetlands remains by the year 2085 , with most of the loss occurring between 2055 and 2060. The lack of lowland areas precludes new wetlands, and thus the column showing hectares gained is uniformly 0 ; however, in other areas this column would help indicate possible wetland migration, which could then be accepted or discounted in the interpretation of the results.

TABLE 4-C.1

SUMMARY OF CHANGES IN WETLAND AREA FOR TUCKERTON, N.J., UNDER THE HIGH SCENARIO

\begin{tabular}{|c|c|c|c|c|}
\hline & Hectares & Percent & HA Lost & HA Gained \\
\hline 1975 & 9900 & 9.9 & 0 & 0 \\
\hline 1980 & 9900 & 9.9 & 0 & 0 \\
\hline 1985 & 9900 & 9.9 & 0 & 0 \\
\hline 1990 & 9900 & 9.9 & 0 & 0 \\
\hline 1995 & 9900 & 9.9 & 0 & 0 \\
\hline 2000 & 9900 & 9.9 & 0 & 0 \\
\hline 2005 & 9900 & 9.9 & 0 & 0 \\
\hline 2010 & 9900 & 9.9 & 0 & 0 \\
\hline 2015 & 9900 & 9.9 & 0 & 0 \\
\hline 2020 & 9900 & 9.9 & 0 & 0 \\
\hline 2025 & 9900 & 9.9 & 0 & 0 \\
\hline 2030 & 9900 & 9.9 & 0 & 0 \\
\hline 2035 & 9900 & 9.9 & 0 & 0 \\
\hline 2040 & 9900 & 9.9 & 0 & 0 \\
\hline 2045 & 9900 & 9.9 & 0 & 0 \\
\hline 2050 & 9900 & 9.9 & 0 & 0 \\
\hline 2055 & 9900 & 9.9 & 0 & 0 \\
\hline 2060 & 2600 & 2.6 & 7300 & 0 \\
\hline 2065 & 2600 & 2.6 & 0 & 0 \\
\hline 2070 & 2500 & 2.5 & 100 & 0 \\
\hline 2075 & 2500 & 2.5 & 0 & 0 \\
\hline 2080 & 100 & 0.1 & 2400 & 0 \\
\hline 2085 & 100 & 0.1 & 0 & 0 \\
\hline 2090 & 100 & 0.1 & 0 & 0 \\
\hline 2095 & 100 & 0.1 & 0 & 0 \\
\hline 2100 & 100 & 0.1 & 0 & 0 \\
\hline
\end{tabular}





\title{
ALTERNATIVES FOR PROTECTING COASTAL WETLANDS FROM THE RISING SEA
}

\author{
by \\ Office of Wetland Protection \\ U.S. Environmental Protection Agency
}

Editor's Note: After reviewing the preceding chapters, EPA's Office of Wetland Protection prepared this concluding chapter, which presents their recommendations for protecting coastal wetlands.

Recognizing the numerous benefits and values accrued to society from wetlands, there are several options available for minimizing potential future losses of wetlands from predicted sea level rise. These protection alternatives focus on methods available to local planners and decisionmakers who can influence regional efforts to ameliorate the impacts on coastal resources associated with sea level rise.

1. Increase wetlands' ability to keep pace with sea level rise.

The ability of wetlands to keep pace with the rising sea will depend in large part on the availability of a reliable sediment source. Both natural and artificial methods for ensuring adequate sedimentation rates would contribute to marsh accretion and development, thereby maintaining the marsh surface level above mean low water. Diversion projects, levee construction, and channelization efforts should each be evaluated in terms of their impacts on supplying necessary sediment. In instances where wetlands are currently subsiding, planners should consider means to increase sediment supply, including river rediversion, levee lowering, jetty construction, or artificial sedimentation practices (e.g., spreading clean dredged material over a wetland; of course, this practice is not necessary for healthy wetlands, only for those in danger of converting to open water due to inadequate sediment nourishment).

2. Protect coastal barriers.

Coastal barrier islands play a critical role in ameliorating the destructive force of wave action on wetlands located landward of the island. The erosive force of the sea will increase as sea level rises and will subsequently play a greater role in destroying wetlands, particularly during storm events. Local efforts to ensure the protection of barrier islands will in turn have a positive impact on preserving the wetlands that lie behind them.

3. Create no-development buffers along the landward edge of wetlands.

As sea level rises, a natural adaptation would permit the existing wetlands to migrate landward to reestablish in inundated areas that currently are uplands. This migration is limited to upland areas that are not developed or bulkheaded. Preventing the development of upland areas adjacent to wetlands could be accomplished through acquisition or regulation (e.g., zoning restrictions). These buffers would also serve to reduce the impacts of nonpoint source pollution of the estuary, and the combination of these benefits should contribute to making this option costeffective. 


\section{Construct tide protection systems.}

Tide gates and physical barriers to the sea could be constructed to protect both wetlands and developed areas that are vulnerable to sea level rise. This type of protection would be very expensive, but in parts of Louisiana such methods are being actively considered to prevent the high rates of wetland loss currently occurring along the Gulf coast.

These and other alternatives are options now available for planners to consider as means to protect vulnerable coastal wetlands. Although, by themselves, these measures do not constitute the entire solution to the problem of sea level rise, they are an important part of integrated, geographic-scale plans for preparing for sea level rise-one that will ensure that the values and functions provided by coastal wetlands are preserved for society's benefit despite the rising sea. 





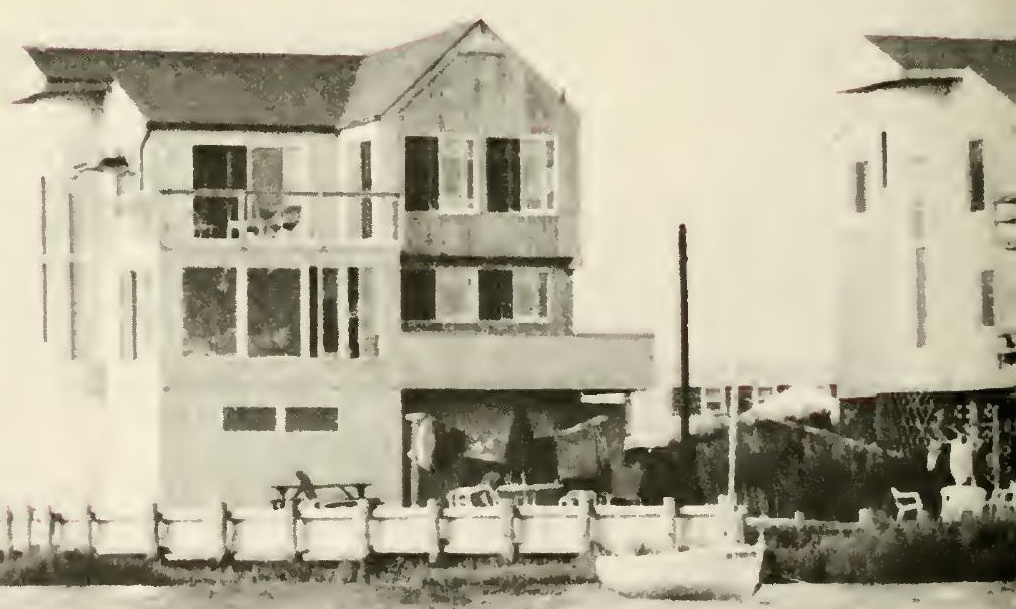

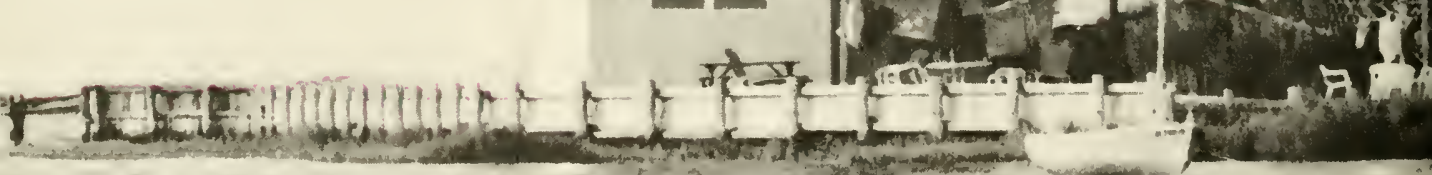

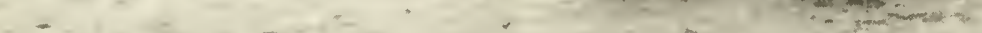

